\title{
Impacts of leaf litter diversity and root resources on microorganisms and microarthropods (Acari, Collembola) during early stages of decomposition in tropical montane rainforest ecosystems
}

\author{
Dissertation \\ zur Erlangung des mathematisch-naturwissenschaftlichen Doktorgrades \\ "Doctor rerum naturalium" \\ der Georg-August-Universität Göttingen \\ im Promotionsprogramm Biologie \\ der Georg-August University School of Science (GAUSS) \\ vorgelegt von \\ M. Sc. \\ Laura Margarita Sánchez Galindo \\ aus \\ Barranquilla, Colombia
}

Göttingen, 22 December 2020 


\section{Betreuungsausschuss}

- Prof. Dr. Stefan Scheu. Animal Ecology, J.F. Blumenbach Institute of Zoology and Anthropology, Göttingen University

- Prof. Dr. Christoph Bleidorn. Animal Evolution and Biodiversity, J.F. Blumenbach Institute of Zoology and Anthropology, Göttingen University

- Prof. Dr. Mark Maraun. Animal Ecology, J.F. Blumenbach Institute of Zoology and Anthropology, Göttingen University

\section{Mitglieder der Prüfungskommission}

Referent: Prof. Dr. Stefan Scheu

Korreferent: Prof. Dr. Christoph Bleidorn

\section{Weitere Mitglieder der Prüfungskommission:}

- Prof. Dr. Mark Maraun

- Prof. Dr. Johannes Kamp. Conservation Biology, Göttingen University

- Prof. Dr. Erwin Bergmeier. Vegetation and Phytodiversity Analysis, Göttingen University

- PD Dr. Klaus Hövemeyer. Animal Ecology, J.F. Blumenbach Institute of Zoology and Anthropology, Göttingen University

Tag der mündlichen Prüfung: 18 Februar 2021 
"Look deep into nature and then you will understand everything better"

Albert Einstein 


\section{Contents}

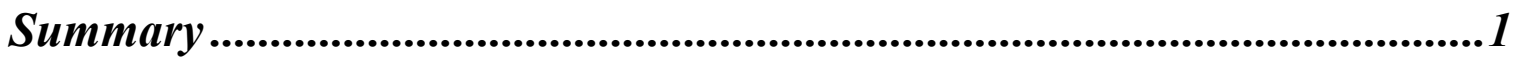

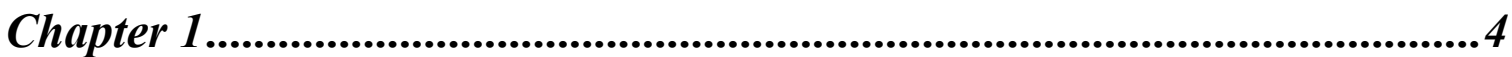

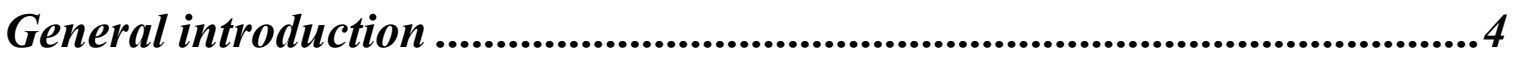

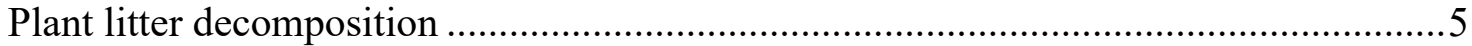

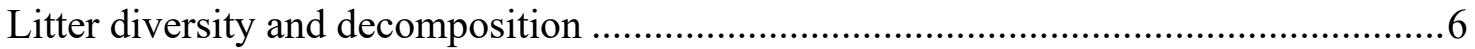

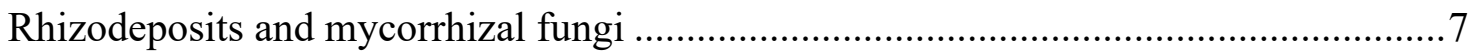

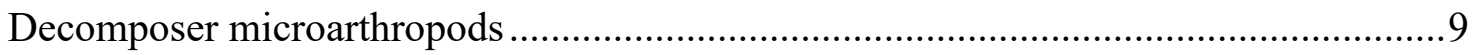

Tropical Andean montane rainforest: the study sites..................................................10

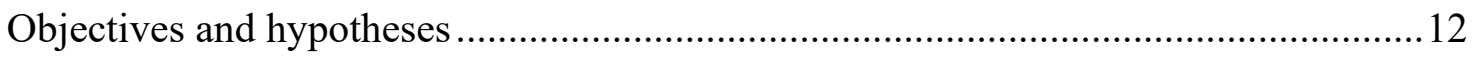

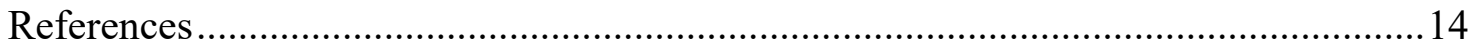

Chapter 2...............................................................................................................22

Leaf litter identity rather than litter diversity shapes microbial functions and microarthropod abundance in tropical montane rainforests.......................22

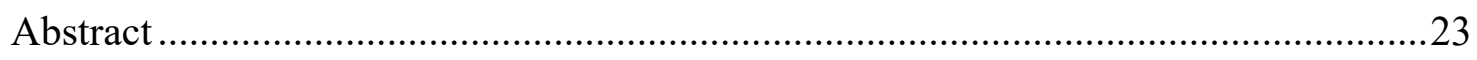

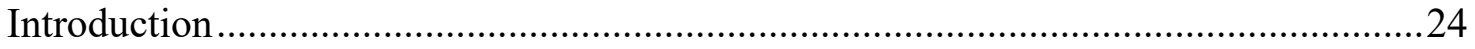

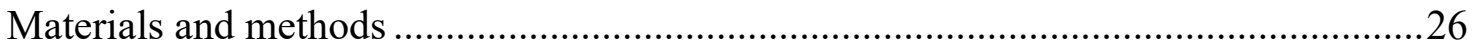

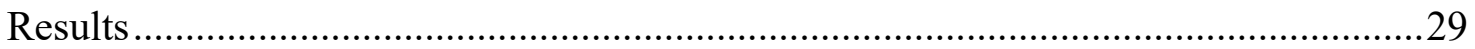

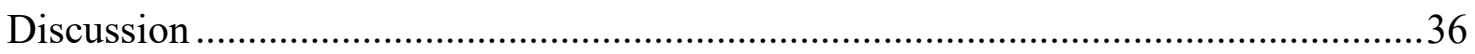

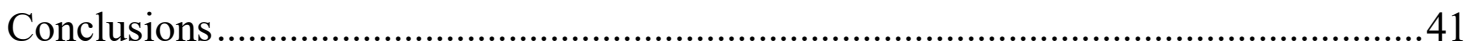

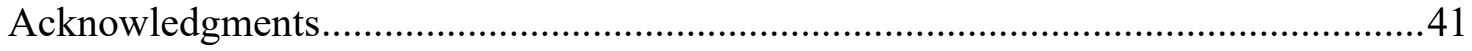

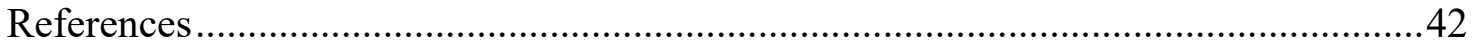

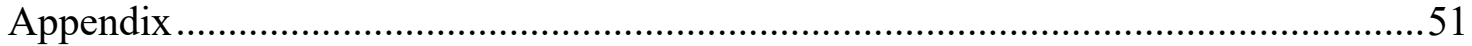

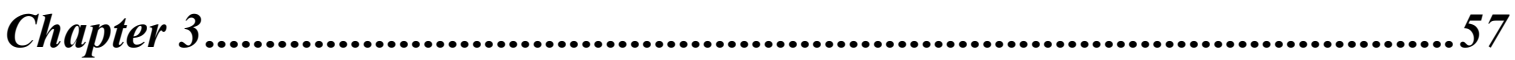

Differences in leaf and root litter decomposition are mediated by soil microorganisms not decomposer microarthropods in tropical montane rainforests .............................................................................................................55

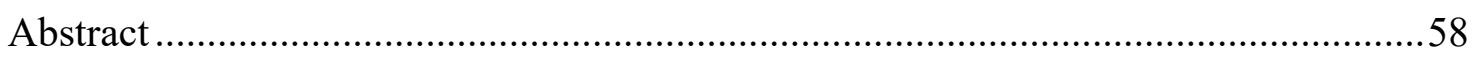

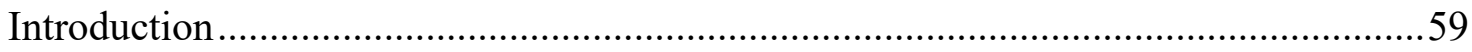

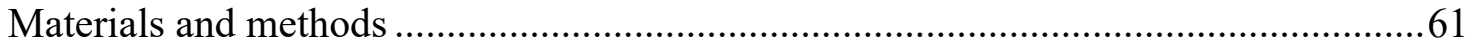

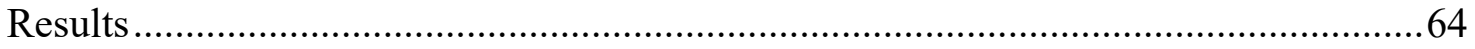

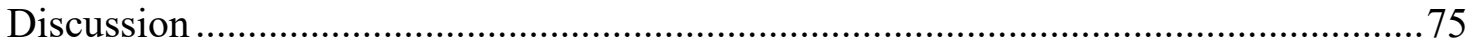




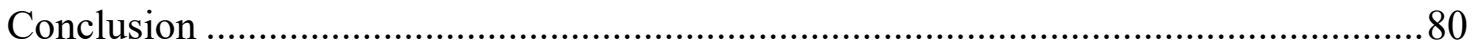

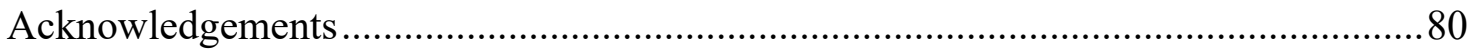

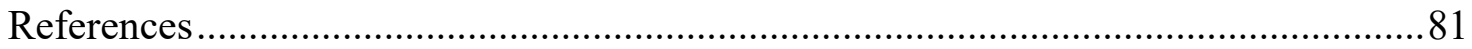

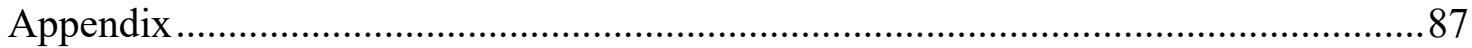

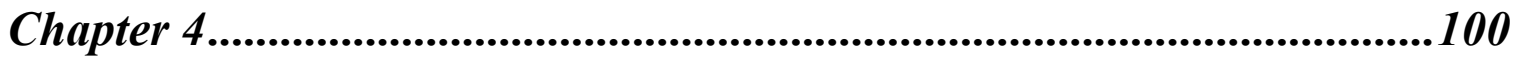

Impacts of core rotation, defaunation and nitrogen addition on arbuscular mycorrhizal fungi, microorganisms and microarthropods in a tropical montane rainforest .........................................................................................100

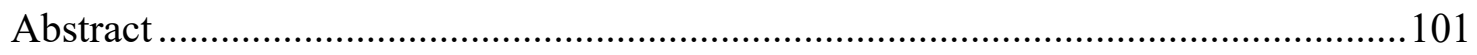

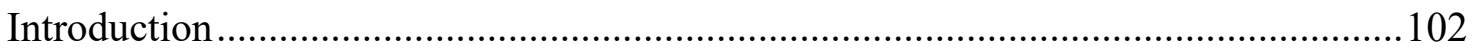

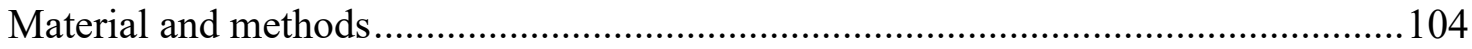

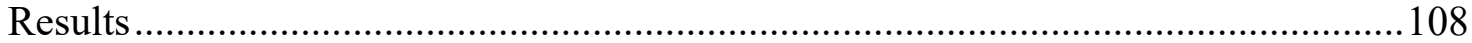

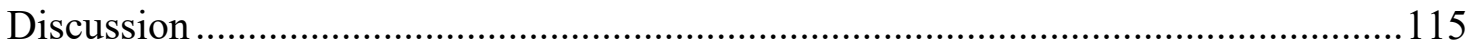

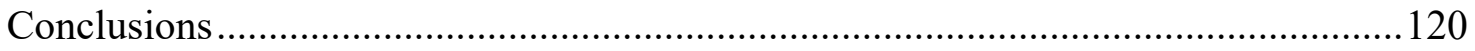

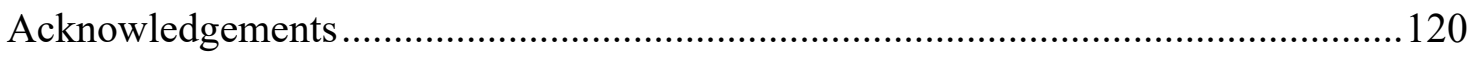

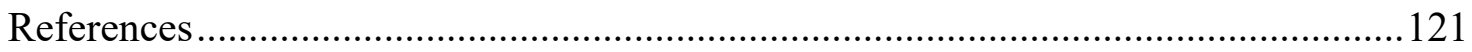

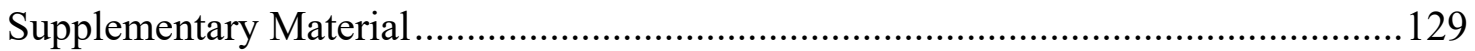

Chapter 5................................................................................................................... 132

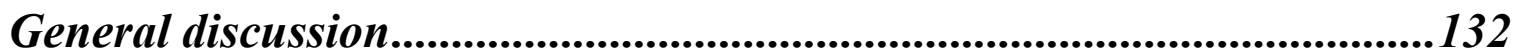

Litter identity drives decomposer organisms and decomposition rates during early stages

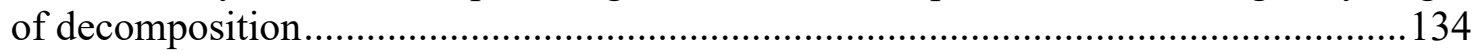

Decomposer microarthropods play a minor role during early stages of litter decomposition

AM fungi: an important actor for determining the abundance and activity of microbial communities during early stages of decomposition.................................................137

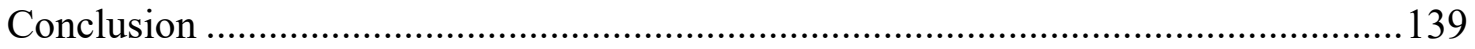

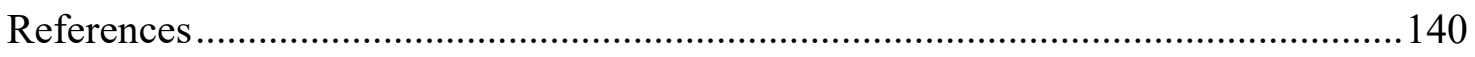

Acknowledgements ................................................................................................ 144

List of publications .......................................................................................... 146

Published in peer-reviewed journals .................................................................146

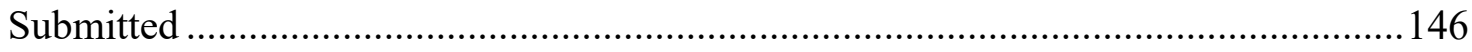

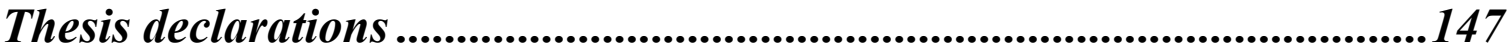

Declaration of the author's own contribution to manuscripts with multiple authors ..147

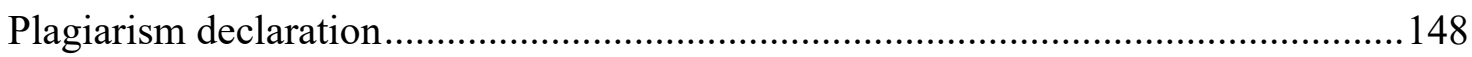




\section{Summary}

Soil organisms influence organic matter turnover and nutrient cycling via processing of organic matter entering the soil as litter and root-derived resources. Plant species differ enormously in the quality and quantity of litter and roots that they produce, and this diversity strongly modifies decomposition of litter by decomposer organisms. Higher plant diversity is generally assumed to improve habitat conditions and availability of resources, thereby improving the abundance and activity of decomposer organisms. Tropical Andean montane rainforest ecosystems harbor an exceptional diversity of plant and animal species. However, little is known on how the huge diversity of plants and root resources affect the activity of soil communities and the overall decomposition rates, particularly during early stages of decomposition. This thesis aims to contribute to our understanding of the effects of leaf litter diversity and root resources on microorganisms and decomposer microarthropods during the early stages of litter decomposition in Andean tropical montane rainforest ecosystems. The studies were performed as field experiments at $2000 \mathrm{~m}$ (Chapter 2 and 4) and along an altitudinal gradient from 1000 to 2000 to $3000 \mathrm{~m}$ (Chapter 3) in a tropical montane rainforest in Southern Ecuador.

Chapter 2 investigates the effect of leaf litter diversity and identity on microbial functions and microarthropod abundance. The results suggest that decomposition and microbial parameters in litter vary with litter diversity as well as litter identity, while microarthropods respond only to litter identity. The results show that higher levels of diversity detrimentally affect soil microbial biomass and result in a decline in litter decomposition. Further, the results indicate that the differential response of soil biota was mostly due to differences in the initial chemical composition of litter species. However, the results also highlight the importance of leaf litter physical traits, particularly on the abundance of decomposer invertebrates. Overall, the results indicate that litter species identity functions as major driver of the abundance and activity of soil organisms and thereby exerts distinct effects on ecosystem processes such as decomposition and nutrient mobilization.

Chapter 3 investigates the contribution of soil microbes and decomposer microarthropods to the decomposition of leaf and root litter along an altitudinal gradient of the studied 
tropical rainforests. The results suggest that the decomposition of both leaf and root litter in montane rainforests is mainly due to microorganisms, whereas the effect of microarthropods is minor along the altitudinal gradient. However, at higher altitudes soil microarthropods accelerate the decomposition of low-quality litter, such as root litter. Further, the study suggests that the abundance of microorganisms as food is of minor importance in structuring decomposer microarthropod communities, underscoring the role of litter quality. Overall, our findings highlight that resource quality or local interspecific variation in litter quality has stronger effects on decomposer organisms regardless climatic variations associated to altitude, at least during early stages of decomposition.

Chapter 4 investigates the response of arbuscular mycorrhizal (AM) fungi, microorganisms and microarthropods to the rotation of hyphal-ingrowth cores, defaunation and nitrogen addition. The results suggest that in the study site AM fungi are closely associated with living roots and do not form extensive extraradical hyphae that can be cut by rotation of the cores. Nonetheless, the results suggest that on top of the litter layer, AM fungi likely compete with saprotrophic microorganisms for litter-derived resources, with mycorrhizal fungi suppressing the activity of saprotrophic microorganisms. While in the soil layer interactions of mycorrhizal fungi with other soil biota are restricted to the close vicinity of roots. Nitrogen addition increased the quality of litter material produced by plants and beneficially affected microbial activity, highlighting that decomposition processes in the studied montane rainforests are strongly limited by nutrient availability and microorganisms in these forests even respond to moderate increase in nitrogen. The results also document a restricted recovery of microorganisms and microarthropods after defaunation of the rotated cores, highlighting the importance of root-derived resources for fueling soil food webs.

Chapter 5 presents a discussion and conclusions on the contribution of the research chapters to the overall state of knowledge. Generally, the results of this thesis suggest that during early stages of decomposition the abundance, diversity and activity of soil organisms are strongly associated with the quality and availability of the litter resources. Overall, the results suggest that decomposition processes in montane rainforests at early stages are mainly driven by microorganisms, whereas the contribution of microarthropods is of minor 
importance. Further, the results also highlight the importance of root-derived resources for fueling soil microarthropod abundance during early stages of decomposition. In addition, the results point to AM fungi as an important player for determining the abundance and activity of microbial communities during early stages of decomposition in tropical montane rainforests. 
Chapter 1

\section{General introduction}
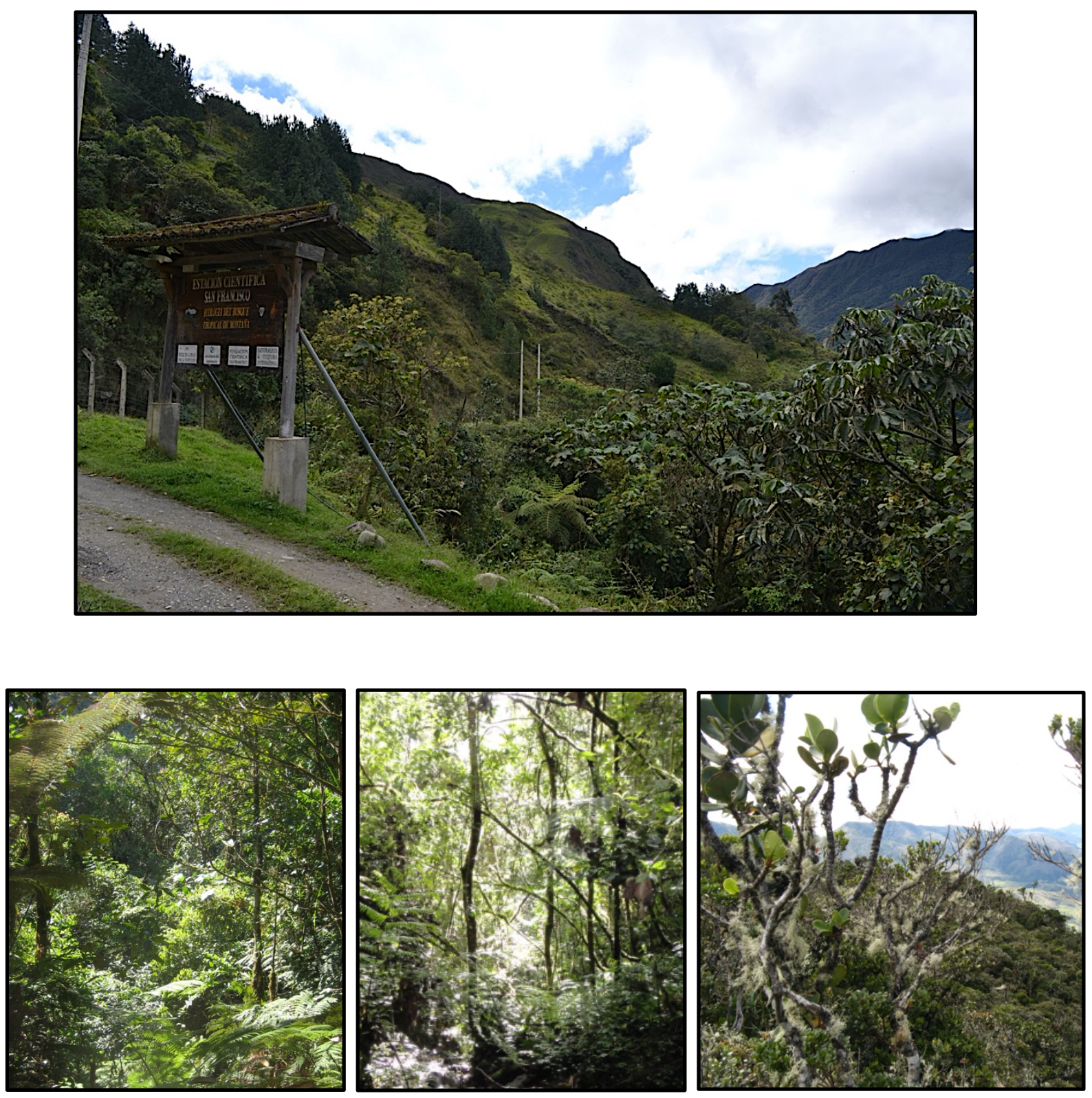


\section{Plant litter decomposition}

Plant litter decomposition is an essential carbon-transforming process that drives nutrient cycling in terrestrial ecosystems (Swift et al. 1979; Bardgett 2005). The breakdown of plant litter material by soil organisms releases nutrients to the soil that are important for plant growth. Simultaneously, this process emits greenhouse gases such as carbon dioxide $\left(\mathrm{CO}_{2}\right)$ to the atmosphere fueling net primary production (Swift et al. 1979; Aerts 1997; Berg and McClaugherty 2008; Krishna and Mohan 2017). Decomposition of plant-litter substrates can be divided into two main stages: (1) the early stage characterized by the loss of ca. $40 \%$ of the litter mass, mostly by the decomposition of labile $\mathrm{C}$ compounds and leaching of water-soluble nutrients, and (2) the late stage in which the remaining mass, mostly recalcitrant material, like lignin, is degraded (Coûteaux et al. 1995; Berg and McClaugherty 2008; Djukic et al. 2018). Changes in the litter substrates during both stages supply different sets of intermediate degradation products that serve as energy and nutrient sources for different populations of soil organisms (Berg and McClaugherty 2008).

Climate, plant-litter quality and decomposer organisms are generally recognized as the main drivers of decomposition rates (Swift et al. 1979; Coûteaux et al. 1995; Aerts 1997). Climate is commonly considered the primary driver of decomposition rates at global scales because factors such as temperature or precipitation can directly alter the sensitivity of soil biological processes and consequently plant-litter quality and soil biota (Wardle et al. 2004; Kutsch et al. 2010; García-Palacios et al. 2013). Plant-litter quality is considered the main controlling factor of litter decomposition rates at the ecosystem level, even though recent studies suggest that litter quality can have stronger effects on decomposition than climate parameters at local to regional scales (Cornwell et al. 2008; Zhang et al. 2008; Fujii et al. 2017). However, the role of decomposer fauna in relation to climate and litter traits is still poorly understood. Therefore, elucidating the role of soil fauna in litter decomposition is necessary for a better understanding of decomposition process in terrestrial ecosystems and is of great importance for predicting carbon dynamics under the future climate-change scenarios. 


\section{Litter diversity and decomposition}

Most of the above-ground plant material produced returns to the soil in form of leaves and woody tissue, representing the major resource of energy and matter for soil organisms (Berg et al. 1993; Berg \& McClaugherty 2008). On the forest floor, a variety of leaf litter species accumulate and decompose as mixture of leaf species. The diversity of leaf litter in mixtures affects decomposer organisms and thereby litter decomposition rates by modifying the physical and chemical characteristics of the litter layer (Gartner and Cardon 2004; Hättenschwiler et al. 2005; Gessner et al. 2010; Handa et al. 2014). Differences in the chemical composition of litter species offer a variety of food resources to detritivores and microorganisms fulfilling their nutritional demands, but also impacting litter decomposition, e.g. by affecting the transfer of nutrients via fungal hyphae (Hättenschwiler et al. 2005; Gessner et al. 2010). Additionally, physical leaf litter characteristics (e.g., toughness, surface structures and shape) that do not necessarily correlate with higher nutrient concentrations, can modify microenvironmental conditions and increase microhabitat diversity for soil animals and, therefore, indirectly affect litter decomposition (Hättenschwiler et al. 2005; Makkonen et al. 2012; Bani et al. 2018).

Considering that more diverse leaf litter mixtures increase habitat variability and thereby may enhance nutrient acquisition by soil organisms, higher diversity of litter is likely to result in faster decomposition rates by maintaining a more abundant and diverse fauna community (Handa et al. 2014; Trogisch et al. 2016). Nonetheless, the current literature shows inconsistent effects of higher leaf litter diversity on soil decomposer communities in different ecosystems (Gartner and Cardon 2004; Nadrowski et al. 2010; Handa et al. 2014). In fact, recent studies have shown that leaf species identity, which encompasses all specific litter chemical and physical characteristics of a single species, has a higher explanatory power for litter decomposition rates and appears to be a better predictor of the interaction effects among litter types and decomposer-driven processes than leaf litter species diversity (Hoorens et al. 2010; Makkonen et al. 2012; Cesarz et al. 2013; Korboulewsky et al. 2016). Thus, it remains controversial whether the positive effect of leaf litter mixtures on decomposition is due to the increase in species diversity or whether it is driven by the identity of the species present in mixtures. 
Traditionally, most litter decomposition studies linking plant species diversity to decomposition have focused on leaf litter traits (Freschet et al. 2012). However, plantspecific litter traits that influence decomposition also vary between the resources provided, i.e. plant organs such as leaves, stems and roots (McLaren and Turkington 2010; Freschet et al. 2013). In fact, the input of root resources may be almost as high as that of leaf litter (Norby et al. 2004; Hobbie et al. 2010) and the different physical and biochemical traits modify not only the characteristics of the resulting soil organic matter, but could also change the structure of soil decomposer communities, and thereby decomposition rates.

\section{Rhizodeposits and mycorrhizal fungi}

Plant roots modify the physical and chemical characteristics of soil organic matter through rhizodeposition, i.e. the release of carbon compounds into the surrounding soil (Hütsch et al. 2002; Dennis et al. 2010). Rhizodeposits, which include root exudates (e.g., sugars, amino acids and organic acids), mucilage, border cells, dead fine roots and gases, modify nutrient availability in soil, thereby affecting the interaction between roots and soil organisms in the rhizosphere (Jones et al. 2004; Bais et al. 2006; Dennis et al. 2010). Particularly, root exudates and fine root litter sustain soil microbial communities at the root surface, where microbial biomass is significantly higher compared to the bulk soil (Bais et al. 2006; Jones et al. 2009; Dennis et al. 2010) providing ample resources for microarthropod communities (Pollierer et al. 2007; Zieger et al. 2017).

A large proportion of carbon released by plant roots is translocated into the soil by mycorrhizal fungi (Brundrett 1991; Hobbie 1992). Mycorrhizal fungi are ubiquitous soil organisms that form symbiotic associations in which the host plant receives mineral nutrients and the fungus obtains photosynthetically fixed carbon compounds (van der Heijden and Sanders 2002; Smith and Read 2008). Seven different categories of mycorrhizal symbiosis have been distinguished on the basis of morphological characteristics, and the fungal and plant species involved (Finlay 2008; Smith and Read 2008). However, the most abundant types of mycorrhizae are arbuscular mycorrhizal (AM), ectomycorrhizal (EM) and ericoid mycorrhizal fungi (ERM) (Brundrett 1991; Johnson and Gehring 2007). 
AM symbiosis is the most widespread type of mycorrhizal association involving fungi from the Glomeromycota phylum associated with a wide range of plant species including grasses, herbs, crops and trees (Johnson and Gehring 2007; Finlay 2008). The symbiosis is characterized by the development of highly branched fungal structures within the cortical cell of the roots forming arbuscules or coils (Bever et al. 2001; Smith and Read 2008). EM is most abundant plant - fungal symbiosis in temperate and boreal forest ecosystems where fungi predominantly from the Basidiomycota and Ascomycota phylum form associations with shrubs and trees, especially conifers. In contrast to AM fungi, EM fungi do not penetrate their hosts cells but rather form a fungal mantle or a network of intercellular hyphae known as Hartig net that is connected to the epidermal and cortical cells and covers the entire host root (Brundrett 2002; Smith and Read 2008). ERM only form associations between various fungi from the Ascomycota phylum and plants belonging to the Ericales order. ERM typically grow in dwarf shrubs in acid and nutrient poor areas, mainly of the tundra regions (Brundrett 1991; Johnson and Gehring 2007) and are characterized by the formation of extensive hyphal coils within root cells during establishment (Perotto et al. 1995; Smith and Read 2008).

EM and ERM fungi are biotrophs with saprotrophic abilities able to take up simple carbon compounds and produce extracellular enzymes that decompose complex organic substrates (Read and Perez-Moreno 2003). By contrast, AM fungi are obligate biotrophs without saprotrophic capabilities (Smith and Read 2008). However, recent studies suggest that AM fungi contribute indirectly to decomposition of complex compounds by influencing the saprotrophic microbial community that decompose complex organic sources and release simple substances for AM hyphal capture (Hodge et al. 2001; Talbot et al. 2008; Nuccio et al. 2013; Leifheit et al. 2015). AM fungi also interact with a wide array of organisms, including bacteria, other fungi, protozoa, nematodes, arthropods and even large animals. These complex interactions among communities of mycorrhizal fungi and other soil organisms can mediate rhizosphere processes and thereby nutrient dynamics and decomposition processes (Fitter and Garbaye 1994; Gryndler 2000). 


\section{Decomposer microarthropods}

Bacteria and fungi are considered the main drivers of soil organic matter breakdown. Nonetheless, feeding activities of the diverse community of soil-dwelling invertebrates also influence decomposition processes (Seastedt 1984; Bardgett 2005; Scheu et al. 2005). Soil microarthropods are a highly diverse and abundant component of invertebrates in soil of virtually any ecosystem (Bardgett 2005). Among soil microarthropods, mites (Acari) and springtails (Collembola) are the most abundant and diverse organisms (Seastedt 1984; Ruess and Lussenhop 2005). Acari and Collembola regulate organic matter turnover and nutrient cycling directly by litter fragmentation or indirectly via trophic interactions with fungal and bacterial communities (Swift et al. 1979; Seastedt 1984; Ruess and Lussenhop 2005). Although the two groups of decomposer microarthropods are considered to occupy similar niches and affect litter decomposition in similar ways, they comprise different trophic levels and differ in a variety of ecological traits (Siepel 1994; Scheu 2002; Schneider et al. 2004; Illig et al. 2005). Differences in the diversity and abundance of Acari and Collembola between ecosystems and their variation even within few centimeters of soil are still little understood, but are likely related to variations in biotic and abiotic factors, such as local climatic conditions and litter quality (Hättenschwiler et al. 2005; Wardle et al. 2006; Gergócs and Hufnagel 2016).

Oribatid mites (Oribatida) are the most species rich Acari subgroup with more than 11,000 described species in 163 families (Subías 2018). Oribatid mites are very common in soils rich in organic matter, reaching densities $>100,000$ individuals per square meter (Maraun and Scheu 2000; Dhooria 2016). Feeding behavior of oribatid mites is diverse and they can be divided into three different trophic groups: microphytophages (species that feed on plant litter material), macrophytophages (species that feed on fungi, pollen, algae, mosses and lichens) and panphytophages (non-specialized species) (Maraun et al. 2003; Dhooria 2016). However, oribatid mites are also known to switch feeding habits when the preferred food is scarce (Maraun et al. 2003; Schneider and Maraun 2005). Oribatid mites typically are characterized by low fecundity and long immature and adult life span (Norton 1994), and have developed strong defense mechanisms, such as protective structures, strong 
sclerotization and defensive glands to be protected themselves from predators (Peschel et al. 2006).

\section{Tropical Andean montane rainforest: the study sites}

Tropical Andean montane rainforest ecosystems are considered one of the hotspots of biodiversity on earth and harbor a particularly high number of endemic vascular plant and animal species (Myers et al. 2000; Beck and Ritcher 2008; Homeier et al. 2008). The vast diversity of plants and animals in these ecosystems is favored by changes in abiotic conditions along the altitudinal gradient (Myers et al. 2000; Beck and Ritcher 2008). In spite of the huge diversity of plants and animals in these ecosystems, few studies investigated the effect of plant litter diversity and root resources on the composition and activity of soil communities and thereby their impacts on litter decomposition processes (Butenschoen et al. 2014; Krashevska et al. 2017; Marian et al. 2017). Previous work on decomposer microarthropods documented that the decomposer fauna in Andean rainforest ecosystems is dominated by small soil invertebrates, such as oribatid mites, collembolans and testate amoebae (Illig et al. 2005; Krashevska et al. 2007; Maraun et al. 2008), and consequently, these groups may play an important role in litter decomposition processes. Litter decomposition rates in tropical montane rainforests are reported to be slower than in lowland tropical rainforests (Heneghan et al. 1998) with the early phase lasting for about 12 months (Marian et al. 2017). One of the reasons for slow decomposition rates may be the general low quality of the litter material. The food quality may limit the abundance and activity of soil decomposer, particularly at higher elevations (Illig et al. 2008; Scheu et al. 2008; Marian et al. 2017).

In Andean topical montane ecosystems roots of plants are in intimate association with litter and may grow towards and throughout litter (Aristizábal et al. 2004). The great majority of tree roots are colonized by AM fungi (Kottke et al. 2004; Camenzind and Rillig 2013) and form pronounced extra-radical mycelia growing even into decomposing litter material (Camenzind and Rillig 2013) stimulating plant nutrients uptake (Delavaux et al. 2017) and likely affecting decomposition by interacting with the microbial community. However, interactions between AM fungi and other organisms have been little studied in Andean 
tropical ecosystems, but may be of significant importance for understanding the role of AM fungi in decomposition processes and nutrient cycling.

Studies presented in this thesis were conducted on the eastern slope of the tropical Andes in southern Ecuador within the northern fringes of the Podocarpus National Park. In this area, three study sites were located at 1000, 2000, and $3000 \mathrm{~m}$ a.s.l. representing an altitudinal gradient with moderately steep slopes of typically $26-31^{\circ}$ (Moser et al. 2007). The lower site at $1000 \mathrm{~m}$ a.s.l. (S04 $\left.06^{\prime} 54^{\prime \prime}, \mathrm{W} 78^{\circ} 58^{\prime} 02^{\prime \prime}\right)$ is located in the Río Bombuscaro valley and is classified as evergreen submontane rainforest dominated by Arecaceae, Combretaceae, Moraceae, Monimiaceae, Rubiaceae and Sapotaceae (Homeier et al. 2008). The intermediate site at $2000 \mathrm{~m}$ a.s.1. (S3 $\left.58^{\prime} 18^{\prime \prime}, \mathrm{W} 79^{\circ} 4^{\prime} 45^{\prime \prime}\right)$ is part of the Reserva Biológica San Francisco located between the cities of Loja and Zamora on the north facing flank of the Río San Francisco valley, and consists of an evergreen lower montane rainforest, with Arecaceae, Clusiaceae, Ericaceae, Lauraceae, Melastomataceae and Rubiaceae being the most widespread tree families (Homeier et al. 2008). The highest site at 3000 m a.s.1. (S04 $06^{\prime} 711^{\prime \prime}$, W $\left.79^{\circ} 10^{\prime} 58^{\prime \prime}\right)$ is located in the south of the city of Loja close to the Cajanuma mountain at the northwest gate of the Podocarpus National Park. The site is characterized by evergreen elfin-forest with the vegetation largely dominated by shrubs and trees of the families Aquifoliaceae, Bromeliaceae, Chloranthaceae, Clusiaceae, Ericaceae and Melastomataceae (Homeier et al. 2008).

The study area has a semi-humid climate with an average annual temperature of $14.9^{\circ} \mathrm{C}$, $12.3{ }^{\circ} \mathrm{C}$ and $8.9^{\circ} \mathrm{C}$, and annual precipitation of approximately 2200,3500 and $4500 \mathrm{~mm}$ at 1000, 2000 and 3000 m a.s.l., respectively (Bendix et al. 2006; Homeier et al. 2010). Soil types of the study sites are alumic Acrisol (1000 m), Gley Cambisol (2000 m) and Podzol (3000 m) (Soethe et al. 2006; Moser et al. 2007). The organic soil layer increases with elevation from $4.8 \mathrm{~cm}$ at $1000 \mathrm{~m}$ to $30.5 \mathrm{~cm}$ at $2000 \mathrm{~m}$ to $43.5 \mathrm{~cm}$ at $3000 \mathrm{~m}$ (Leuschner et al. 2007; Graefe et al. 2008). Fine roots are concentrated in organic layers (Wilcke et al. 2002) and its biomass increase in parallel with the soil organic layer from $2.7 \mathrm{tha}^{-1}$ at 1000 $\mathrm{m}$ to $6.2 \mathrm{t} \mathrm{ha}^{-1}$ at $2000 \mathrm{~m}$ to $10.8 \mathrm{tha}^{-1}$ at $3000 \mathrm{~m}$ (Soethe et al. 2006). 


\section{Objectives and hypotheses}

This thesis aims to deepen our understanding of the role of leaf litter diversity and root resources on microorganisms and decomposer microarthropods during early stages of litter decomposition in tropical montane rainforest ecosystems.

The main hypotheses of this thesis are the following:

1. Higher leaf litter diversity results in faster decomposition rates, and an increase in the abundance and diversity of decomposer communities.

2. The abundance and diversity of the soil decomposer organisms is regulated by litter quality and differ between plant organs (leaf and fine root litter).

3. Decomposer microarthropods are similarly involved in the decomposition of leaf and root litter during early stages of decomposition in tropical montane rainforests.

4. Root-derived resources and carbon inputs via AM fungi increase the abundance, activity and diversity of soil microorganisms and microarthropods within the organic layer, indirectly altering litter decomposition rates. These effects vary with the nutrient status of the ecosystem being lower at higher nutrient availability.

The study presented in Chapter $\mathbf{2}$ aims at quantifying the impact of leaf litter identity and diversity on the abundance and activity of microorganisms and decomposer microarthropods. I hypothesized microbial growth and activity to increase with litter diversity, but the abundance of decomposer microarthropods to rely more on litter identity than litter diversity. Further, I hypothesized that nutrient availability increases with time reducing microbial stress conditions. I also hypothesized that the abundance of decomposer microarthropods increases as decomposition proceeds. Lastly, I hypothesized that the presence of high-quality litter benefits microorganisms, as well as the abundance of decomposer microarthropods. 
The study presented in Chapter 3 investigates how microorganisms and soil decomposer microarthropods affect leaf and root decomposition along an altitudinal gradient of the tropical montane rainforests studied. The access of soil fauna to the litter was controlled by using litterbags of different mesh size. Due to less favorable abiotic conditions with increasing altitude. I hypothesized that the decomposition of litter, regardless of litter tissue, decreases with increasing altitude. I further hypothesized that limiting the access of litter by microarthropods accelerates decomposition by increasing microbial biomass and activity in both leaf and root litter, with the effect being stronger at higher altitudes where nutrients are more limited. Further, I hypothesized that the abundance of decomposer microarthropods and the diversity of oribatid mites is higher in leaf than in root litter irrespective of altitude, and increase with increasing microbial biomass. Lastly, I hypothesized that the role of litter quality in structuring oribatid mite communities declines with time, with the effect being less pronounced in root than in leaf litter.

The study presented in Chapter $\mathbf{4}$ investigates the response of AM fungi, microorganisms and microarthropods to the rotation of hyphal-ingrowth cores, defaunation and nitrogen addition. I hypothesized that the colonization of the cores by AM fungi is reduced by regular rotation of the cores and that the reduction of mycorrhizal hyphae results in an increased activity of saprotrophic microorganisms, thereby accelerating decomposition processes. I further hypothesized that the increase in saprotrophic organisms, particularly fungi, in rotated cores benefit oribatid mites. In addition, I hypothesized that the addition of $\mathrm{N}$ reduces the concentration of $\mathrm{AM}$ fungi, but fosters the activity of saprotrophic microorganisms and thereby increases litter decomposition. 


\section{References}

Aerts R (1997) Climate, leaf litter chemistry and leaf litter decomposition in terrestrial ecosystems: A triangular relationship. Oikos 79:439

Aristizábal C, Rivera EL, Janos DP (2004) Arbuscular mycorrhizal fungi colonize decomposing leaves of Myrica parvifolia, M. pubescens and Paepalanthus sp. Mycorrhiza 14:221-228

Bais HP, Weir TL, Perry LG, et al (2006) The role of root exudates in rhizosphere interactions with plants and other organisms. Annu Rev Plant Biol 57:233-266

Bani A, Pioli S, Ventura M, et al (2018) The role of microbial community in the decomposition of leaf litter and deadwood. Appl Soil Ecol 126:75-84

Bardgett RD (2005) The Biology of soils: A community and ecosystem approach. Oxford University Press

Beck E, Ritcher M (2008) Ecological aspects of a biodiversity hotspot in the Andes of southern Ecuador. Biodivers. Ecol. Ser. 195-217

Bendix J, Homeier J, Cueva Ortiz E, et al (2006) Seasonality of weather and tree phenology in a tropical evergreen mountain rain forest. Int J Biometeorol 50:370-384

Berg B, Berg MP, Bottner P, et al (1993) Litter mass loss rates in pine forests of Europe and Eastern United States: some relationships with climate and litter quality. Biogeochemistry 20:127-159

Berg B, McClaugherty C (2008) Plant litter, Second ed. Springer-Verlag Berlin Heidelberg

Bever JD, Schultz PA, Pringle A, Morton JB (2001) Arbuscular mycorrhizal fungi: More diverse than meets the eye, and the ecological tale of why. Bioscience 51:923-932

Brundrett M (1991) Mycorrhizas in natural ecosystems. Academic Press Limited ISBN

Brundrett MC (2002) Coevolution of roots and mycorrhizas of land plants. New Phytol 154:275304

Butenschoen O, Krashevska V, Maraun M, et al (2014) Litter mixture effects on decomposition in tropical montane rainforests vary strongly with time and turn negative at later stages of decay. Soil Biol Biochem 77:121-128 
Camenzind T, Rillig MC (2013) Extraradical arbuscular mycorrhizal fungal hyphae in an organic tropical montane forest soil. Soil Biol Biochem 64:96-102

Cesarz S, Ruess L, Jacob M, et al (2013) Tree species diversity versus tree species identity: Driving forces in structuring forest food webs as indicated by soil nematodes. Soil Biol Biochem 62:36-45

Cornwell WK, Cornelissen JHC, Amatangelo K, et al (2008) Plant species traits are the predominant control on litter decomposition rates within biomes worldwide. Ecol Lett 11:1065-1071

Coûteaux MM, Bottner P, Berg B (1995) Litter decomposition, climate and litter quality. Tree 10:63-66

Delavaux CS, Camenzind T, Homeier J, et al (2017) Nutrient enrichment effects on mycorrhizal fungi in an Andean tropical montane Forest. Mycorrhiza 27:311-319

Dennis PG, Miller AJ, Hirsch PR (2010) Are root exudates more important than other sources of rhizodeposits in structuring rhizosphere bacterial communities? FEMS Microbiol Ecol 72:313-327

Dhooria MS (2016) Soil mites. In: Fundamentals of Applied Acarology. Springer, Singapore, pp $197-206$

Djukic I, Kepfer-Rojas S, Schmidt IK, et al (2018) Early stage litter decomposition across biomes. Sci Total Environ 628-629:1369-1394

Finlay RD (2008) Ecological aspects of mycorrhizal symbiosis: With special emphasis on the functional diversity of interactions involving the extraradical mycelium. $J$ Exp Bot 59:11151126

Fitter A, Garbaye J (1994) Interactions between mycorrhizal fungi and other soil organisms. Plant Soil 159:123-132

Freschet GT, Aerts R, Cornelissen JHC (2012) A plant economics spectrum of litter decomposability. Funct Ecol 26:56-65

Freschet GT, Cornwell WK, Wardle DA, et al (2013) Linking litter decomposition of above- and below-ground organs to plant-soil feedbacks worldwide. J Ecol 101:943-952

Fujii S, Cornelissen JHC, Berg MP, Mori AS (2017) Tree leaf and root traits mediate soil faunal 
contribution to litter decomposition across an elevational gradient. Funct Ecol 32:840-852

García-Palacios P, Maestre FT, Kattge J, Wall DH (2013) Climate and litter quality differently modulate the effects of soil fauna on litter decomposition across biomes. Ecol Lett 16:10451053

Gartner T, Cardon Z (2004) Decomposition dynamics in mixed-species leaf litter. Oikos 104:230-246

Gergócs V, Hufnagel L (2016) The effect of microarthropods on litter decomposition depends on litter quality. Eur J Soil Biol 75:24-30

Gessner MO, Swan CM, Dang CK, et al (2010) Diversity meets decomposition. Trends Ecol Evol 25:372-380

Graefe S, Hertel D, Leuschner C (2008) Fine root dynamics along a $2000 \mathrm{~m}$ elevation transect in South Ecuadorian mountain rainforests. Plant Soil 313:155-166

Gryndler M (2000) Interactions of arbuscular mycorrhizal fungi with other soil organisms. In: Kapulnik Y, Douds DD (eds) Arbuscular Mycorrhizas: Physiology and Function. Springer, Dordrecht, pp 239-262

Handa IT, Aerts R, Berendse F, et al (2014) Consequences of biodiversity loss for litter decomposition across biomes. Nature 509:218-221

Hättenschwiler S, Tiunov A V., Scheu S (2005) Biodiversity and litter decomposition in terrestrial ecosystems. Annu Rev Ecol Evol Syst 36:191-218

Heneghan L, Coleman DC, Zou X, et al (1998) Soil microarthropod community structure and litter decomposition dynamics: A study of tropical and temperate sites. Appl Soil Ecol 9:3338

Hobbie SE (1992) Effects of plant species on nutrient cycling. Tree 7:336-339

Hobbie SE, Oleksyn J, Eissenstat DM, Reich PB (2010) Fine root decomposition rates do not mirror those of leaf litter among temperate tree species. Oecologia 162:505-513

Hodge A, Campbell CD, Fitter AH (2001) An arbuscular mycorrhizal fungus accelerates decomposition and achqires nitrogen directly from organic material. Nature 413:297-299

Homeier J, Breckle S, Günter S, et al (2010) Tree diversity, forest structure and productivity 
along altitudinal and topographical gradients in a species-rich Ecuadorian montane rain forest. Biotropica 42:140-148

Homeier J, Werner FA, Gradstein SR, et al (2008) Potential vegetation and floristic composition of Andean forests in south Ecuador, with a focus on the RBSF. In: Beck E, Bendix J, Kottke I, et al. (eds) Gradients in a Tropical Mountain Ecosystem of Ecuador. Springer, Berlin, Heidelberg, pp 87-100

Hoorens B, Coomes D, Aerts R (2010) Neighbour identity hardly affects litter-mixture effects on decomposition rates of New Zealand forest species. Oecologia 162:479-489

Hütsch BW, Augustin J, Merbach W (2002) Plant rhizodeposition - An important source for carbon turnover in soils. J Plant Nutr Soil Sci 165:397-407

Illig J, Langel R, Norton RA, et al (2005) Where are the decomposers? Uncovering the soil food web of a tropical montane rain forest in southern Ecuador using stable isotopes $(15 \mathrm{~N})$. $J$ Trop Ecol 21:589-593

Illig J, Schatz H, Scheu S, Maraun M (2008) Decomposition and colonization by microarthropods of two litter types in a tropical montane rain forest in southern Ecuador. $J$ Trop Ecol 24:157-167

Johnson NC, Gehring CA (2007) Mycorrhizas: Symbiotic mediators of rhizosphere and ecosystem processes. In: Cardon ZG, Whitbeck JLBT-TR (eds) The rhizosphere: An ecological perspective. Academic Press, Burlington, pp 73-100

Jones DL, Hodge A, Kuzyakov Y (2004) Plant and mycorrhizal regulation of rhizodeposition. New Phytol 163:459-480

Jones DL, Nguyen C, Finlay RD (2009) Carbon flow in the rhizosphere: Carbon trading at the soil-root interface. Plant Soil 321:5-33

Korboulewsky N, Perez G, Chauvat M (2016) How tree diversity affects soil fauna diversity: A review. Soil Biol Biochem 94:94-106

Kottke I, Beck A, Oberwinkler F, et al (2004) Arbuscular endomycorrhizas are dominant in the organic soil of a neotropical montane cloud forest. J Trop Ecol 20:125-129

Krashevska V, Bonkowski M, Maraun M, Scheu S (2007) Testate amoebae (protista) of an elevational gradient in the tropical mountain rain forest of Ecuador. Pedobiologia (Jena) 
$51: 319-331$

Krashevska V, Sandmann D, Marian F, et al (2017) Leaf litter chemistry drives the structure and composition of soil Testate Amoeba communities in a tropical montane rainforest of the Ecuadorian Andes. Microb Ecol 74:681-690

Krishna MP, Mohan M (2017) Litter decomposition in forest ecosystems: a review. Energy, Ecol Environ 2:236-249

Kutsch WL, Bahn M, Heinemeyer A (2010) Soil carbon dynamics: An integrated methodology, 1st edn. Cambridge University Press, Cambridge, UK

Leifheit EF, Verbruggen E, Rillig MC (2015) Arbuscular mycorrhizal fungi reduce decomposition of woody plant litter while increasing soil aggregation. Soil Biol Biochem $81: 323-328$

Leuschner C, Moser G, Bertsch C, et al (2007) Large altitudinal increase in tree root/shoot ratio in tropical mountain forests of Ecuador. Basic Appl Ecol 8:219-230

Makkonen M, Berg MP, Handa IT, et al (2012) Highly consistent effects of plant litter identity and functional traits on decomposition across a latitudinal gradient. Ecol Lett 15:1033-1041

Maraun M, Illig J, Sandmann D, et al (2008) Soil Fauna. In: Beck E, Bendix J, Kottke I, et al. (eds) Gradients in a tropical mountain ecosystem of Ecuador. Springer, Berlin, Heidelberg, pp 181-192

Maraun M, Martens H, Migge S, et al (2003) Adding to "the enigma of soil animal diversity": Fungal feeders and saprophagous soil invertebrates prefer similar food substrates. Eur J Soil Biol 39:85-95

Maraun M, Scheu S (2000) The structure of oribatid mite communities (Acari, Oribatida): Patterns, mechanisms and implications for future research. Ecography (Cop) 23:374-382

Marian F, Sandmann D, Krashevska V, et al (2017) Leaf and root litter decomposition is discontinued at high altitude tropical montane rainforests contributing to carbon sequestration. Ecol Evol 7:6432-6443

McLaren JR, Turkington R (2010) Plant functional group identity differentially affects leaf and root decomposition. Glob Chang Biol 16:3075-3084

Moser G, Hertel D, Leuschner C (2007) Altitudinal change in LAI and stand leaf biomass in 
tropical montane forests: A transect study in ecuador and a pan-tropical meta-analysis. Ecosystems 10:924-935

Myers N, Mittermeier R, Mittermeier C, et al (2000) Biodiversity hotspots for conservation priorities. Nature 403:853-858

Nadrowski K, Wirth C, Scherer-Lorenzen M (2010) Is forest diversity driving ecosystem function and service? Curr Opin Environ Sustain 2:75-79

Norby RJ, Ledford J, Reilly CD, et al (2004) Fine-root production dominates response of a deciduous forest to atmospheric $\mathrm{CO}_{2}$ enrichment. Proc Natl Acad Sci U S A 101:9689-9693

Norton RA (1994) Evolutionary aspects of Oribatid mite life histories and consequences for the origin of the Astigmata. In: Houck MA (ed) Mites. Springer, Boston, pp 99-135

Nuccio EE, Hodge A, Pett-ridge J, et al (2013) An arbuscular mycorrhizal fungus significantly modifies the soil bacterial community and nitrogen cycling during litter decomposition. Environ Microbiol 15:1870-1881

Perotto S, Peretto R, Faccio A, et al (1995) Ericoid mycorrhizal fungi: cellular and molecular bases of their interactions with the host plant. Can J Bot 73:557-568

Peschel K, Norton RA, Scheu S, Maraun M (2006) Do oribatid mites live in enemy-free space? Evidence from feeding experiments with the predatory mite Pergamasus septentrionalis. Soil Biol Biochem 38:2985-2989

Pollierer MM, Langel R, Körner C, et al (2007) The underestimated importance of belowground carbon input for forest soil animal food webs. Ecol Lett 10:729-736

Read DJ, Perez-Moreno J (2003) Mycorrhizas and nutrient cycling in ecosystems - A journey towards relevance? New Phytol 157:475-492

Ruess L, Lussenhop J (2005) Trophic interactions of fungi and animals. In: Dighton J, Oudemans $\mathrm{P}$, White J (eds) The fungal community: its organization and role in the ecosystem. CRC, Boca Raton, pp 581-598

Scheu S (2002) The soil food web: Structure and perspectives. Eur J Soil Biol 38:11-20

Scheu S, Illig J, Eissfeller V, et al (2008) The soil fauna of a tropical mountain rainforest in southern Ecuador: structure and functioning. In: Gradstein SR, Gansert D, Homeier J (eds) The tropical mountain forest. Patterns and processes in a biodiversity hotspots. pp 79-96 
Scheu S, Ruess L, Bonkowski M (2005) Interactions and soil micro- and mesofauna. In: Buscot F, Varma A (eds) Microorganisms in soils: roles in genesis and functions. pp 253-275

Schneider K, Maraun M (2005) Feeding preferences among dark pigmented fungal taxa ("Dematiacea") indicate limited trophic niche differentiation of oribatid mites (Oribatida, Acari). Pedobiologia (Jena) 49:61-67

Schneider K, Migge S, Norton RA, et al (2004) Trophic niche differentiation in soil microarthropods (Oribatida, Acari): Evidence from stable isotope ratios $\left({ }^{15} \mathrm{~N} /{ }^{14} \mathrm{~N}\right)$. Soil Biol Biochem 36:1769-1774

Seastedt TR (1984) The role of microarthropods in decomposition and mineralization processes. Annu Rev Entomol Vol 29 25-46

Siepel H (1994) Life-history tactics of soil microarthropods. Biol Fertil Soils 18:263-278

Smith SE, Read DJ (2008) Mycorrhizal symbiosis, 3rd edn. Academy Press. Cambridge, UK

Soethe N, Lehmann J, Engels C (2006) The vertical pattern of rooting and nutrient uptake at different altitudes of a south Ecuadorian montane forest. Plant Soil 286:287-299

Subías LS (2018) Listado sistemático, sinonímico y biogeográfico de los ácaros oribátidos (Acariformes: Oribatida ) del mundo (Excepto fósiles)(13 ${ }^{\mathrm{a}}$ actualización). http://www.ucm.es/info/zoo/Artropodos/Catalogo.pdf.

Swift M, Heal O, Anderson J (1979) Decomposition in Terrestrial Ecosystems. Oxford University Press

Talbot JM, Allison SD, Treseder KK (2008) Decomposers in disguise: Mycorrhizal fungi as regulators of soil C dynamics in ecosystems under global change. Funct Ecol 22:955-963

Trogisch S, He JS, Hector A, Scherer-Lorenzen M (2016) Impact of species diversity, stand age and environmental factors on leaf litter decomposition in subtropical forests in China. Plant Soil 400:337-350

van der Heijden MGA, Sanders IR (2002) Mycorrhizal ecology, 1st edn. Springer-Verlag Berlin Heidelberg

Wardle DA, Bardgett RD, Klironomos JN, et al (2004) Ecological linkages between aboveground and belowground biota. Science 304:1629-1633 
Wardle DA, Yeates GW, Barker GM, Bonner KI (2006) The influence of plant litter diversity on decomposer abundance and diversity. Soil Biol Biochem 38:1052-1062

Wilcke W, Yasin S, Abramowski U, et al (2002) Nutrient storage and turnover in organic layers under tropical montane rain forest in Ecuador. Eur J Soil Sci 53:15-27

Zhang D, Hui D, Luo Y, Zhou G (2008) Rates of litter decomposition in terrestrial ecosystems: global patterns and controlling factors. J Plant Ecol 1:85-93

Zieger SL, Ammerschubert S, Polle A, Scheu S (2017) Root-derived carbon and nitrogen from beech and ash trees differentially fuel soil animal food webs of deciduous forests. PLoS One $12: 1-14$ 
Chapter 2

\section{Leaf litter identity rather than litter diversity shapes microbial functions and microarthropod abundance in tropical montane rainforests}

Laura M. Sánchez-Galindo, Dorothee Sandmann, Franca Marian, Valentyna Krashevska, Mark Maraun \& Stefan Scheu
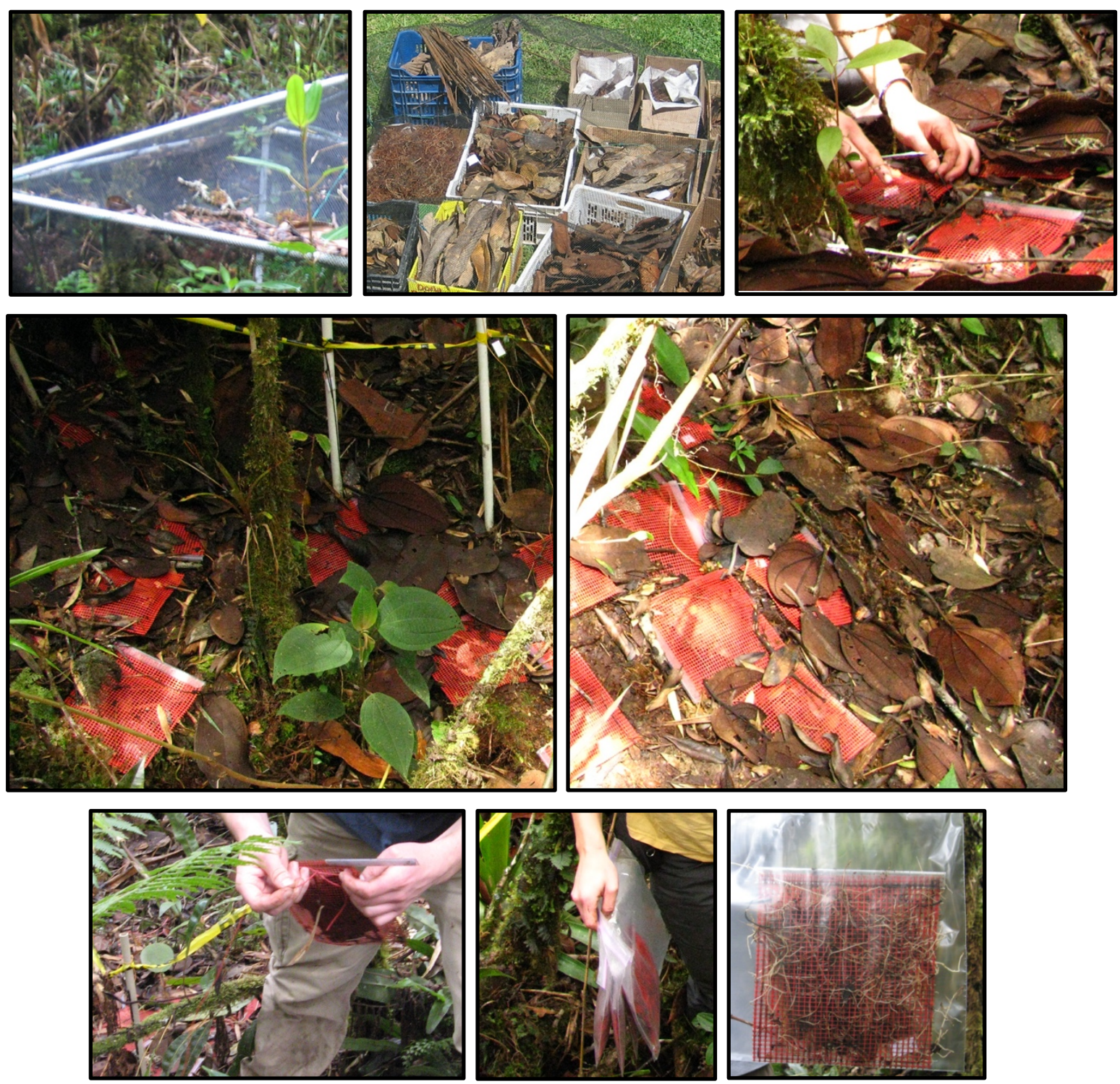


\section{Abstract}

In tropical forest ecosystems leaf litter from a large variety of species enters the decomposer system, however, the impact of leaf litter diversity on the abundance and activity of soil organisms during decomposition is little known. We investigated the effect of leaf litter diversity and identity on microbial functions and the abundance of microarthropods in Ecuadorian tropical montane rainforests. We used litterbags filled with leaves of six native tree species (Cecropia andina, Dictyocaryum lamarckianum, Myrcia pubescens, Cavendishia zamorensis, Graffenrieda emarginata and Clusia spp.) and incubated monocultures and all possible two and four species combinations in the field for 6 and 12 months. Mass loss, microbial biomass, basal respiration, metabolic quotient and the slope of microbial growth after glucose addition, as well as the abundance of microarthropods (Acari and Collembola) were measured at both sampling dates. Leaf litter diversity significantly increased mass loss after 6 months of exposure, but reduced microbial biomass after 12 months of exposure. Leaf litter species identity significantly changed both microbial activity and microarthropod abundance with species of high quality (low C-to-N ratio), such as $C$. andina, improving resource quality as indicated by lower metabolic quotient and higher abundance of microarthropods. Nonetheless, species of low quality, such as Clusia spp., also increased the abundance of Oribatida suggesting that leaf litter chemical composition alone is insufficient to explain variation in the abundances of soil microarthropods. Overall, the results provide evidence that decomposition and microbial biomass in litter respond to leaf litter diversity as well as litter identity (chemical and physical characteristics), while microarthropods respond only to litter identity but not litter diversity.

Keywords: Acari; Collembola; decomposition; litterbags; litter quality; microorganisms; metabolic quotient. 


\section{Introduction}

The great majority of plant material enters the soil as litter, in the form of leaves, stems and roots. Decomposition of these materials is an essential process for nutrient cycling and provides the basal resources of the soil food web (Berg et al. 1993; Berg and McClaugherty 2008). In addition to providing food resources, leaf litter accumulating on the soil surface forms a variety of microhabitats for soil organisms, with more diverse litter materials increasing habitat variability, but also providing the opportunity for enhanced nutrient acquisition (Bardgett 2005; Gessner et al. 2010). Therefore, high diversity of leaf litter in mixtures is expected to be an important determinant of the diversity and structure of decomposer communities and, consequently, litter decomposition (Hättenschwiler et al. 2005; Gessner et al. 2010; Trogisch et al. 2016).

Tropical montane rainforest ecosystems harbor an exceptional diversity of plant species (Myers et al. 2000; Beck and Ritcher 2008; Homeier et al. 2008) and are associated with high numbers of animal species above- and belowground (Brehm et al. 2008; Maraun et al. 2008; Paulsch and Müller-Hohenstein 2008). However, the effect of plant litter diversity on decomposer communities and decomposition of litter in this ecosystems is little studied (Illig et al. 2008; Krashevska et al. 2017). Controlled experiments are needed to assess the effect of diversity and composition of litter species in mixtures on litter decomposition and microarthropod abundance.

Differences in leaf-litter chemical composition are recognized as the main drivers of decomposition rates at the ecosystem level (Coûteaux et al. 1995; Hättenschwiler et al. 2005). Studies have reported positive, negative, but also no effects of litter mixtures on decomposition, with mixture effects typically related to variations in litter nutrient concentrations (Gartner and Cardon 2004; Makkonen et al. 2012; Handa et al. 2014). However, differences in litter chemistry are not the only factors contributing to variations in litter decomposition in mixtures (Hoorens et al. 2003; Hättenschwiler 2005). Physical leaf litter traits, such as toughness, surface structure and shape, also contribute to microhabitat diversity and modify micro-environmental conditions of decomposer organisms, resulting either in accelerated or decelerated litter decomposition (Hansen and Coleman 1998; Kaneko and Salamanca 1999). Therefore, species identity, which 
encompasses chemical and physical characteristics, may well explain diversity effects on decomposition. Indeed, the effect of litter species identity has been found to be more powerful in explaining colonization of litter by invertebrates than litter diversity (Schädler and Brandl 2005; Wardle et al. 2006; Vos et al. 2011; Eissfeller et al. 2013; Korboulewsky et al. 2016).

Commonly, studies investigating effects of litter diversity on litter decomposition focused on microorganisms and detritivore invertebrates (Gessner et al. 2010). Microorganisms are assumed to respond more sensitively to litter diversity than invertebrates as they directly depend on the variety of litter chemical compounds needed for metabolism and growth (Bardgett and Shine 1999; Chapman et al. 2013). By contrast, the response of invertebrate detritivores, particularly the key decomposer groups Acari and Collembola, more strongly depends on the identity rather than diversity of leaf litter species and varies with the stage of litter decomposition (Kaneko and Salamanca 1999; González and Seastedt 2001; Wardle et al. 2006; Illig et al. 2008; Korboulewsky et al. 2016). Indeed, many decomposer microarthropods have the ability to select among co-occurring leaf litter species according to litter palatability and/or the microorganisms colonizing the litter (Klironomos et al. 1992; Schneider and Maraun 2005; Korboulewsky et al. 2016). Studies linking microbialdominated litter decomposition processes and colonization of litter by detritivore invertebrates are needed to uncover the mechanisms responsible for litter diversity effects on the structure and functioning of the decomposer system, particularly in tropical ecosystems characterized by high diversity of plant (tree) species.

In the present study, we investigated the effect of leaf litter diversity and identity on the colonization of litter by microorganisms and microarthropods including Acari and Collembola after 6 and 12 months of incubation in Ecuadorian montane rainforests. We hypothesized that (1) microbial growth and activity increase with litter diversity, but that the abundance of both Acari and Collembola relies more on litter identity. Additionally, assuming that microorganisms are limited by multiple nutrients (Demoling et al. 2007; Krashevska et al. 2010), we hypothesized that (2) nutrient availability increases and microbial stress conditions decrease with time, and that (3) the presence of high-quality litter benefits microorganisms. Further, assuming that Acari and Collembola prefer similar food resources and consume both leaf litter tissue and microorganisms (Seastedt 1984; 
Ruess and Lussenhop 2005; Dhooria 2016), we hypothesized that (4) the abundance of Acari and Collembola increases as decomposition proceeds, particularly in presence of high-quality litter.

\section{Materials and methods}

\section{Study site}

The study area is located in southern Ecuador on the eastern slopes of the Andean Cordillera. The site forms part of the Reserva Biológia San Francisco located on the northern borders of the Podocarpus National Park at $2000 \mathrm{~m}$ a.s.1. $\left(3^{\circ} 58^{\prime} \mathrm{S}, 79^{\circ} 04^{\prime} \mathrm{W}\right)$. The region is characterized by a semi-humid climate with annual precipitation of about 2200 $\mathrm{mm}$ and average annual temperature of $15.2^{\circ} \mathrm{C}$ (Bendix et al. 2006; Wullaert et al. 2009). The soil is Gley Cambisol with a soil $\mathrm{pH}$ of $\sim 3.5$ and a thick organic layer up to $35 \mathrm{~cm}$ comprised of mainly fermentation/humus material overlaid by litter material (Moser et al. 2007). The tropical rainforest is mostly undisturbed and holds an exceptionally high diversity of fauna and flora with Rubiaceae, Melastomataceae and Piperaceae as dominant plant families (Brehm and Fiedler 2005; Beck and Ritcher 2008; Maraun et al. 2008; Homeier et al. 2010)

\section{Experimental design}

In September 2008, freshly fallen leaves of six common plant species at the study sites [Cecropia andina (Cuatrec.) (CA), Dictyocaryum lamarckianum (H. Wendl.) (DL), Myrcia pubescens (Humb. \& Bonpl. ex Willd.) (MP), Cavendishia zamorensis (A. C. Sm.) (CZ), Graffenrieda emarginata (Ruiz \& Pav.) (GE) and Clusia spp. (L.) (Cs); ordered by increasing C-to-N ratio, see Appendix 1], were collected, dried $\left(60^{\circ} \mathrm{C}\right.$ for $\left.72 \mathrm{~h}\right)$ and used to fill $20 \times 20 \mathrm{~cm}$ and $4 \mathrm{~mm}$ nylon mesh litterbags. Initial chemical composition of the litter species is given in Appendix 1. The leaves used had no signs of herbivory, fungal infection or atypical texture or color. Large leaves exceeding the size of the litter bags, were cut into $\sim 5 \times 5 \mathrm{~cm}$ pieces. Single-species litterbags (12 $\mathrm{g}$ each) and mixtures with all possible two(6 g per species) and four-species combinations ( $3 \mathrm{~g}$ per species) were prepared, resulting in a total of 36 litterbag types with three levels of species diversity $(1,2$, and 4 leaf litter 
species). Litterbags were randomly placed in the field on top of the undisturbed litter layer and fixed with nails in four blocks. Minimum distance between the blocks was $20 \mathrm{~m}$. One replicate of each treatment was harvested after 6 and 12 months.

\section{Analytical procedures}

After harvest, material in each litterbag was separated into two subsamples of equal weight, disturbing the fauna as little as possible but ensuring that all litter types were present in both halves. One half was used for microarthropod extraction and the other for analysis of microbial parameters. Microarthropods were extracted by heat over one week using a modified high gradient extractor and then stored in 70\% ethanol (Macfadyen 1961; Kempson et al. 1963). Microarthropods were determined to group level [Collembola (Insecta), Oribatida, Mesostigmata and Prostigmata (Acari)] using Schaefer (2018). The dry litter was sorted to species, weighed and used to measure litter chemical composition.

Microbial basal respiration (BR) and microbial biomass $\left(\mathrm{C}_{\text {mic }}\right)$ were determined using an automated respirometer system (Scheu 1992). BR ( $\mu \mathrm{O}_{2} \mathrm{~g}^{-1}$ dry weight $\mathrm{h}^{-1}$ ) was measured at $22{ }^{\circ} \mathrm{C}$ and calculated as mean of $\mathrm{O}_{2}$ consumption rates 10 to $20 \mathrm{~h}$ after attachment of the samples to the respirometer system. $\mathrm{C}_{\text {mic }}$ was measured by the substrate-induced respiration method (SIR; Anderson and Domsch, 1978; Beck et al., 1997). The maximum initial respiratory response (MIRR; $\mu 1 \mathrm{O}_{2} \mathrm{~g}^{-1}$ dry weight $\mathrm{h}^{-1}$ ) was measured at $22{ }^{\circ} \mathrm{C}$ after the addition of glucose to saturate the catabolic activity of microorganisms. MIRR was calculated as the average of the lowest three readings within the first $10 \mathrm{~h}$ and $\mathrm{C}_{\text {mic }}$ was calculated as $\mathrm{C}_{\text {mic }}=38 \times$ MIRR ( $\mathrm{mg} \mathrm{g}^{-1}$ dry weight). Respiration rates between the lowest (usually 3-6 $\mathrm{h}$ after glucose addition) and highest reading were taken to calculate the slope of microbial growth $\left(+\mathrm{C}_{\text {Slope }}\right)$. Data were $\mathrm{ln}$-transformed and the slope determined by linear regression. The microbial metabolic quotient $\left(q \mathrm{O}_{2} ; \mu \mathrm{O}_{2} \mathrm{mg}^{-1} \mathrm{C}_{\mathrm{mic}} \mathrm{h}^{-1}\right)$ was calculated by dividing $\mathrm{BR}$ by $\mathrm{C}_{\text {mic }}$.

Leaf litter mass loss $\left(\mathrm{M}_{\text {loss }}\right)$ was calculated as $M_{\text {loss }}(\%)=\left(\left(m_{0}-m_{1} / m_{0}\right)\right) \times 100$, where $m_{0}$ is the initial dry weight and $m_{1}$ the dry weight of leaf litter at harvest. To measure chemical composition, leaves from each of the six species were dried $\left(65^{\circ} \mathrm{C}\right.$ for $\left.72 \mathrm{~h}\right)$ and milled to particles $<1 \mathrm{~mm}$. Carbon (C) and nitrogen (N) were measured using a $\mathrm{CN}$ 
elemental analyzer (Vario EL III, Elementar, Hanau, Germany). Total element analysis was measured by an ICP-OES system (ICP-OES, Optima 5300 DV, Perkin Elmer, USA). Lignin and cellulose concentration were measured based on the methanol-chloroformwater (2:2:1) extraction method detailed in Allen et al. (1974). For litter mixtures, the proportion of elements per litterbag was calculated by proportionally summing the amount of the respective elements in the individual litter species. The chemical concentrations of elements, lignin and cellulose was expressed as milligram per gram litter dry weight (dw).

\section{Statistical analyses}

Analyses were performed using R version 3.6.0 (R Core Team 2014). Data was checked for normality and homoscedasticity using Shapiro-Wilk test and Bartlett's test (package "stats"). To improve normality and homoscedasticity, data were transformed using the "bestNormalize" function (package "CRAN"). Changes in $\mathrm{M}_{\text {loss, }} \mathrm{C}_{\text {mic }}, \mathrm{BR}, q \mathrm{O}_{2},+\mathrm{C}_{\text {slope }}$ and the abundance of microarthropod taxa (Collembola, Oribatida, Mesostigmata and Prostigmata) were analyzed using individual linear mixed-effects models (package "nlme"). In each model the fixed factors litter diversity (LD; 1, 2 and 4 litter species), time of exposure (6 and 12 months) and the presence/absence all leaf litter species (litter identity; 1,0; CA, DL, MP, CZ, GE and Cs), as well as the interactions (time $\times$ LD and time $\times$ litter identity) were fitted in a hierarchical design. Block was fitted first as random factor followed by the fixed factors litter diversity, time, interaction between litter diversity and time, and litter identity. To assess the relative importance of the six leaf litter species, analyses were repeated changing the order of fitting individual litter species and their interactions. F- and P-values for individual litter species in the text and tables refer to those when fitted first (Schmid et al. 2002, 2017). Differences between means were inspected using Tukey's honestly significant difference test (package “emmeans"). Values presented in text are means $\pm \mathrm{SD}$ of non-transformed data. Pearson correlation coefficients were calculated to investigate relationships between C-to-N ratio, $\mathrm{C}_{\text {mic }}, q \mathrm{O}_{2}$ and $\mathrm{M}_{\text {loss, }}$ and the abundance of Collembola and Acari (package "stats"). 


\section{Results}

\section{Initial litter chemistry}

Initial $\mathrm{N}$ concentrations were highest in $C$. andina, followed by D. lamarckianum, $M$. pubescens, C. zamorensis, G. emarginata and Clusia spp. (1.08\%, 0.73\%, 0.60\%, 0.50\%, $0.40 \%$ and $0.40 \%$, respectively), resulting in C-to-N ratios between 36.3 in C. andina and 107.2 in Clusia spp. (see Appendix 1 for details on litter chemistry). Lignin concentrations were generally high and varied between $63.9 \%$ in Clusia spp. to $42.6 \%$ in G. emarginata. By contrast, concentrations of cellulose were lowest in Clusia spp. (13.0\%), low in $C$. andina (29.6\%), but similar in the other four litter species varying between $35.8 \%$ and 40.7\%. Concentrations of $\mathrm{P}$ and other litter elements also varied markedly between leaf litter species with $\mathrm{P}, \mathrm{Ca}, \mathrm{Mg}, \mathrm{K}$ and $\mathrm{Fe}$ being highest in $C$. andina, and $\mathrm{P}$ and $\mathrm{Ca}$ being lowest in G. emarginata.

\section{Mass loss}

Generally, $\mathrm{M}_{\text {loss }}$ was higher after 12 than after 6 months of incubation with averages of $52.6 \% \pm 7.1 \%$ and $41.8 \% \pm 6.9 \%$ of initial, respectively (Table 1 ). $\mathrm{M}_{\text {loss }}$ varied significantly with species diversity but the effect depended on time (Figure 1A; Table 1); after 6 months $\mathrm{M}_{\text {loss }}$ was lower in single species (average of $29.6 \% \pm 6.9 \%$ ) compared to the two and four litter species treatments $(43.1 \% \pm 3.8$ and $44.9 \% \pm 3.6 \%$, respectively), while after 12 months decomposition was similar in each of the litter diversity treatments. Further, $\mathrm{M}_{\text {loss }}$ varied significantly with litter species identity, however, this depended on time, with the effect generally being restricted to the first sampling date and to four of the six litter species (Table 1). At the first sampling date, $\mathrm{M}_{\text {loss }}$ increased in presence of $C$. andina from $39.7 \%$ $\pm 7.4 \%$ to $44.4 \% \pm 5.1 \%$, in presence of C. zamorensis from $40.5 \% \pm 7.9 \%$ to $43.2 \% \pm$ $5.3 \%$, in presence of G. emarginata from $39.4 \% \pm 7.6 \%$ to $44.8 \% \pm 4.2 \%$ and in presence of Clusia spp. from $39.6 \% \pm 7.3 \%$ to $44.6 \% \pm 5.1 \%$. Mloss positively correlated with $\mathrm{C}_{\text {mic }}$, BR, $q \mathrm{O}_{2},+\mathrm{C}_{\text {Slope }}$ and the abundance of Collembola and Oribatida, but negatively with the litter C-to-N ratio (Pearson correlation coefficients; Table 2). 


\begin{tabular}{lcccccc}
\hline & df & $\mathbf{M}_{\text {loss }}$ & $\mathbf{C}_{\text {mic }}$ & BR & $\mathbf{q O}_{\mathbf{2}}$ & $+\mathbf{C}_{\text {Slope }}$ \\
\hline \hline LD & 2,239 & $\mathbf{2 6 . 3 2}^{* * * *}$ & $\mathbf{3 . 0 1}^{* *}$ & 1.12 & 2.01 & 2.03 \\
Time & 1,239 & $\mathbf{2 4 4 . 0 3}^{* * *}$ & $\mathbf{3 1 . 4 8}^{* * *}$ & $\mathbf{7 8 . 1 0}^{* * *}$ & $\mathbf{2 1 . 1 5}^{* * *}$ & $\mathbf{2 4 . 6 1}^{* * *}$ \\
CA & 1,239 & 0.51 & 1.63 & 1.04 & $\mathbf{7 . 7 6}^{* * *}$ & 1.21 \\
DL & 1,239 & 1.09 & $<0.01$ & 1.78 & 1.93 & $\mathbf{4 . 5 9}^{*}$ \\
MP & 1,239 & 2.09 & $<0.01$ & $\mathbf{3 . 9 1}^{*}$ & 0.46 & 0.70 \\
CZ & 1,239 & 0.02 & 0.53 & $<0.01$ & $\mathbf{4 . 4 9}^{* *}$ & $\mathbf{4 . 3 3}^{*}$ \\
GE & 1,239 & 0.43 & 0.11 & 0.04 & $<0.01$ & 0.05 \\
Cs & 1,239 & 0.97 & 0.05 & 0.02 & $<0.01$ & 0.01 \\
Time $\times$ LD & 2,239 & $\mathbf{4 3 . 4 4}^{* * *}$ & $\mathbf{4 . 3 7}^{* *}$ & 1.43 & 1.27 & 1.73 \\
Time $\times$ CA & 1,239 & $\mathbf{2 3 . 0 1}^{* * *}$ & 0.12 & 0.01 & $<0.01$ & 2.30 \\
Time $\times$ DL & 1,239 & 0.91 & 0.47 & 0.11 & 0.66 & $\mathbf{3 . 8 9}$ \\
Time $\times$ MP & 1,239 & 1.76 & 0.60 & 3.13 & 0.60 & 0.59 \\
Time $\times$ CZ & 1,239 & $\mathbf{7 . 2 5}^{* *}$ & 0.71 & 0.80 & $\mathbf{3 . 7 6}^{*}$ & 2.48 \\
Time $\times$ GE & 1,239 & $\mathbf{3 5 . 1 2}^{* * *}$ & $\mathbf{6 . 7 6}^{* *}$ & 2.29 & 0.60 & $<0.01$ \\
Time $\times$ Cs & 1,239 & $\mathbf{2 1 . 7 3}^{* * *}$ & 1.77 & 0.07 & 0.02 & 2.72 \\
\hline
\end{tabular}

Table 1. F-values of linear mixed effects models on the effect of litter species diversity (LD), time of exposure (Time) and leaf litter species identity [Cecropia andina (CA), Dictyocaryum lamarckianum (DL), Myrcia pubescens (MP), Cavendishia zamorensis (CZ), Graffenrieda emarginata (GE) and Clusia spp. (Cs)] on mass loss $\left(\mathrm{M}_{\mathrm{loss}}\right)$, microbial biomass $\left(\mathrm{C}_{\mathrm{mic}}\right)$, basal respiration (BR), microbial metabolic quotient $\left(q \mathrm{O}_{2}\right)$ and the slopes of microbial growth after $\mathrm{C}$ addition $\left(+\mathrm{C}_{\text {Slope }}\right)$. F-values represent those where the respective factor was fitted first. Significant effects are given in bold $(* \mathrm{P}<0.05 ; * * \mathrm{P}<0.01 ; * * * \mathrm{P}<0.001)$; df, degrees of freedom. 

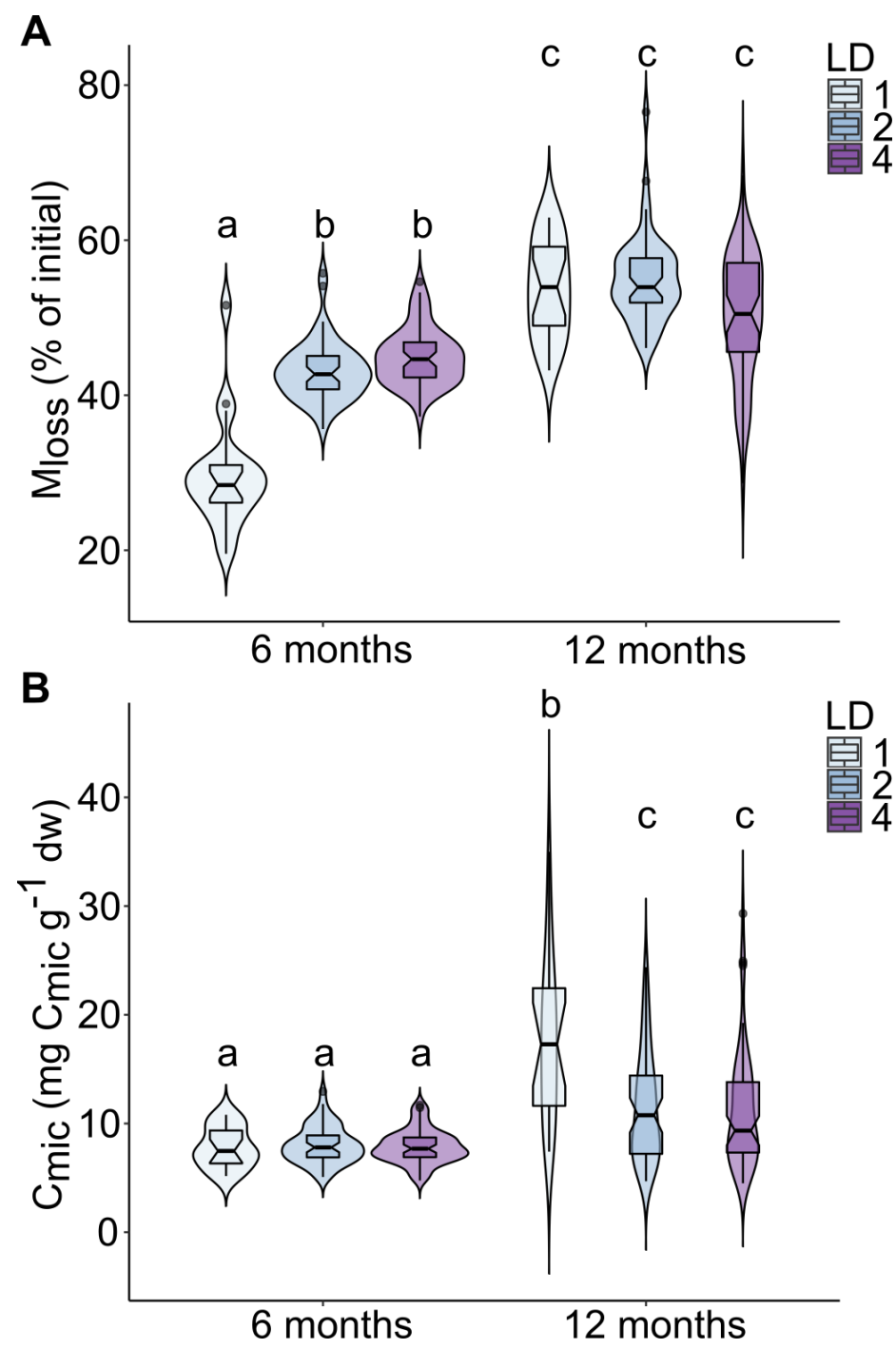

Figure 1. Effect of litter species diversity (LD; 1, 2 and 4 species) on (A) litter mass loss ( $\left.\mathrm{M}_{\text {loss }}\right)$ and $(\mathrm{B})$ litter microbial biomass $\left(\mathrm{C}_{\mathrm{mic}}\right)$ after 6 and 12 months of incubation in the field. Boxplots show medians and quantiles for each LD level. Violin plot illustrate kernel probability density. Different letters indicate significant differences (Tukey's HSD test, $\mathrm{P}<0.05$ 


\begin{tabular}{|c|c|c|c|c|c|c|c|c|c|}
\hline & $\mathbf{M}_{\text {loss }}$ & $\mathbf{C}_{\text {mic }}$ & BR & $q \mathrm{CO}_{2}$ & $+\mathbf{C}_{\text {Slope }}$ & Collembola & Oribatida & Mesostigmata & Prostigmata \\
\hline$\overline{M_{\text {loss }}}$ & $\bar{~} 1$ & - & - & - & - & $\overline{-1}$ & - & - & - \\
\hline $\mathrm{C}_{\mathrm{mic}}$ & $0.30^{* * * *}$ & 1 & - & - & - & - & - & - & - \\
\hline BR & $0.42^{* * *}$ & $0.53^{* * * *}$ & 1 & - & - & - & - & - & - \\
\hline$q \mathrm{O}_{2}$ & $0.20^{* * *}$ & $-0.16^{* * *}$ & $0.50^{* * * *}$ & 1 & - & - & - & - & - \\
\hline$+\mathrm{C}_{\text {slope }}$ & $0.20^{* *}$ & $0.23^{* * *}$ & $0.38^{* * *}$ & 0.07 & 1 & - & - & - & - \\
\hline Collembola & $0.16^{* *}$ & 0.09 & 0.04 & -0.10 & 0.12 & 1 & - & - & - \\
\hline Oribatida & $0.25^{* * *}$ & 0.08 & $0.13^{*}$ & 0.04 & 0.12 & $0.50^{* * * *}$ & 1 & - & - \\
\hline Mesostigmata & -0.05 & -0.07 & $-0.15^{*}$ & $-0.16^{*}$ & -0.05 & $0.40^{* * * *}$ & $0.40^{* * * *}$ & 1 & - \\
\hline Prostigmata & 0.05 & 0.02 & $<0.01$ & -0.11 & 0.07 & $0.37^{* * *}$ & $0.39^{* * *}$ & $0.48^{* * *}$ & 1 \\
\hline C-to-N & $-0.24^{* * * *}$ & $-0.16^{*}$ & $-0.19^{* * *}$ & 0.05 & $-0.15^{*}$ & $-0.15^{*}$ & -0.01 & -0.07 & $-0.19^{* * * *}$ \\
\hline
\end{tabular}

Table 2. Pearson correlation coefficients between mass loss $\left(\mathrm{M}_{\mathrm{loss}}\right)$, microbial biomass $\left(\mathrm{C}_{\mathrm{mic}}\right)$, basal respiration (BR), microbial growth after $\mathrm{C}$ addition $\left(+\mathrm{C}_{\text {slope }}\right)$, metabolic quotient $\left(q \mathrm{O}_{2}\right)$, the abundance of Collembola, Oribatida, Mesostigmata and Prostigmata and litter $\mathrm{C}$-to-N ratio. Significant correlations are given in bold $\left({ }^{*} \mathrm{P}<0.05 ; * * \mathrm{P}<0.01 ; * * * \mathrm{P}<0.001\right)$. 


\section{Microbial parameters}

Parallel to $\mathrm{M}_{\text {loss, }}$, the microbial parameters $\mathrm{C}_{\text {mic }}, \mathrm{BR}, q \mathrm{O}_{2}$ and $+\mathrm{C}_{\text {Slope }}$ significantly increased from 6 to 12 months (Table 1; for means see Appendix 2). Among microbial parameters, only $\mathrm{C}_{\text {mic }}$ varied with litter diversity. Unlike $\mathrm{M}_{\text {loss }}$, the effect of litter diversity was restricted to the second sampling date, decreasing in the order one $>$ two $>$ four litter species (Figure 1B). Further, $\mathrm{C}_{\text {mic }}$ also varied with litter species identity, but the effect was restricted to treatments with $G$. emarginata and depended on time. At the second sampling date $\mathrm{C}_{\mathrm{mic}}$ decreased from $15.23 \pm 11.74$ to $11.58 \pm 7.37 \mathrm{mg} \mathrm{C}_{\mathrm{mic}} \mathrm{g}^{-1} \mathrm{dw}$ in litterbags without and with G. emarginata, respectively. The other microbial parameters only were significantly affected by litter species identity, with the effects in part varying with time (Table 1). BR decreased significantly in presence of $M$. pubescens from an average of $157.3 \pm 107.7$ to $133.1 \pm 69.40 \mu 1 \mathrm{O}_{2} \mathrm{mg}^{-1} \mathrm{C}_{\text {mic }} \mathrm{h}^{-1}$ in litterbags without and with $M$. pubescens, respectively. $q \mathrm{O}_{2}$ decreased from $14.90 \pm 5.65$ to $13.50 \pm 4.18 \mu \mathrm{I} \mathrm{O}_{2} \mathrm{mg}^{-1} \mathrm{C}_{\mathrm{mic}} \mathrm{h}^{-1}$ in presence of $C$. andina, irrespective of sampling date, but it increased from $14.44 \pm 5.37$ to $16.91 \pm 7.4545$ $\mu \mathrm{O}_{2} \mathrm{mg}^{-1} \mathrm{C}_{\mathrm{mic}} \mathrm{h}^{-1}$ in presence of C. zamorensis at the second sampling date. $+\mathrm{C}_{\text {Slope }}$ decreased significantly from $0.0097 \pm 0.0149$ to $0.0061 \pm 0.0131$ in presence of $C$. zamorensis irrespective of sampling date, but in presence of D. lamarckianum it increased from $0.0086 \pm 0.0195$ to $0.0151 \pm 0.0180$ after the second sampling.

Pearson correlation coefficients indicated that $\mathrm{C}_{\text {mic }}$ positively correlated with $\mathrm{M}_{\mathrm{loss}}, \mathrm{BR}$ and $+\mathrm{C}_{\text {Slope, }}$, but negatively with $q \mathrm{O}_{2}$ and the litter C-to-N ratio. BR positively correlated with $\mathrm{M}_{\text {loss, }}, \mathrm{C}_{\text {mic }}, q \mathrm{O}_{2},+\mathrm{C}_{\text {slope }}$ and the abundance of Oribatida, but negatively with the abundance of Mesostigmata and the litter C-to-N ratio. $q \mathrm{O}_{2}$ positively correlated with $\mathrm{M}_{\text {loss }}$ and $\mathrm{BR}$, but negatively with $\mathrm{C}_{\mathrm{mic}}$ and the abundance of Mesostigmata. $+\mathrm{C}_{\text {Slope }}$ positively correlated with $\mathrm{M}_{\text {loss }}, \mathrm{C}_{\mathrm{mic}}$, BR, but negatively with the litter C-to-N ratio (Table 2).

\section{Microarthropods}

The number of Collembola, Oribatida and Prostigmata significantly increased from 6 to 12 months, but the abundance of Mesostigmata decreased (Figure 2; Table 3; for means see Appendix 3). None of the soil microarthropod taxa investigated varied with litter diversity, 
although they did vary significantly with litter species identity (Table 3). Collembola abundance (25.3\% of total microarthropods; overall mean of $70 \pm 80$ ind. $10 \mathrm{~g}^{-1}$ litter $\mathrm{dw}$ ) increased significantly in presence of $C$. andina by $43.4 \%$ and in presence of $G$. emarginata by $29.2 \%$, but decreased in presence of D. lamarckianum and C. zamorensis by $39.1 \%$ and $38.1 \%$, respectively (Appendix 3 and 4). However, the effect varied with time for $D$. lamarckianum and C. zamorensis (Table 3); in the presence of these species the reduction was most pronounced after 12 months (from $60 \pm 42$ to $123 \pm 132$ and from $62 \pm 38$ to 124 \pm 135 ind. $10 \mathrm{~g}^{-1}$ litter $\mathrm{dw}$, respectively). The abundance of Oribatida (53.7\% of total microarthropods; overall mean $146 \pm 119$ ind. $10 \mathrm{~g}^{-1}$ litter $\mathrm{dw}$ ) increased significantly in litterbags containing G. emarginata or Clusia spp. from $133 \pm 119$ to $162 \pm 118$ and from $131 \pm 99$ to $163 \pm 138$ ind. $10 \mathrm{~g}^{-1}$ litter dw, respectively. Further, Mesostigmata abundance (11.1\% of total microarthropods; overall mean of $30 \pm 27$ ind. $10 \mathrm{~g}^{-1}$ litter $\mathrm{dw}$ ) decreased significantly by $24.5 \%$ from $34 \pm 31$ to $26 \pm 21$ ind. $10 \mathrm{~g}^{-1}$ litter $\mathrm{dw}$ in the presence of $C$. zamorensis. Prostigmata abundance (9.5\% of total microarthropods; overall mean of $26 \pm$ 22 ind $10 \mathrm{~g}^{-1}$ litter $\mathrm{dw}$ ) increased significantly in litterbags where C. andina or Clusia spp. were present. With the former, it increased by $28.1 \%$ from $23 \pm 22$ to $29 \pm 22$ ind. $10 \mathrm{~g}^{-1}$ litter $\mathrm{dw}$, while in the presence of the latter the effect was restricted to the second sampling date, increasing by $23.1 \%$ from $27 \pm 25$ to $33 \pm 26$ ind. $10 \mathrm{~g}^{-1}$ litter $\mathrm{dw}$.

Pearson correlation coefficients indicated that Collembola abundance positively correlated with $\mathrm{M}_{\text {loss }}$ and the abundance of Oribatida, Mesostigmata and Prostigmata, but negatively with the litter C-to-N ratio. Oribatida abundance positively correlated with $\mathrm{M}_{\text {loss, }}, \mathrm{BR}$ and the abundance of Collembola, Mesostigmata and Prostigmata. Mesostigmata abundance positively correlated with the abundance of Collembola, Oribatida and Prostigmata, but negatively with $\mathrm{BR}$ and $q \mathrm{O}_{2}$. Prostigmata abundance positively correlated with the abundance of Collembola, Oribatida and Mesostigmata, but negatively with litter C-to-N ratio (Table 2). 


\begin{tabular}{|c|c|c|c|c|c|}
\hline & df & Collembola & Oribatida & Mesostigmata & Prostigmata \\
\hline LD & 2,239 & 0.15 & 1.41 & 0.75 & 0.74 \\
\hline Time & 1,239 & $28.08^{* * * *}$ & $78.95^{* * *}$ & $4.93^{*}$ & $4.22^{*}$ \\
\hline CA & 1,239 & $15.83^{* * *}$ & 1.50 & 2.86 & $7.92^{* * *}$ \\
\hline DL & 1,239 & $13.34^{* * * *}$ & 0.34 & 0.05 & 0.66 \\
\hline MP & 1,239 & $<0.01$ & 0.85 & 0.37 & 2.74 \\
\hline $\mathrm{CZ}$ & 1,239 & $8.80^{* *}$ & 2.73 & $4.61^{*}$ & 2.06 \\
\hline GE & 1,239 & $7.59^{* *}$ & $5.98^{* * *}$ & 2.43 & 1.56 \\
\hline $\mathrm{Cs}$ & 1,239 & $<0.01$ & $4.24^{*}$ & 0.07 & 0.02 \\
\hline Time $\times$ LD & 2,239 & 2.80 & 0.61 & 0.71 & 0.39 \\
\hline Time $\times$ CA & 1,239 & 0.14 & 0.59 & 2.26 & 3.08 \\
\hline Time $\times$ DL & 1,239 & $8.04^{* *}$ & 0.02 & 1.01 & 0.42 \\
\hline Time $\times$ MP & 1,239 & 0.85 & 0.30 & 0.23 & 0.03 \\
\hline Time $\times C Z$ & 1,239 & $4.52^{*}$ & 0.01 & 0.01 & $<0.01$ \\
\hline Time $\times$ GE & 1,239 & 0.22 & 0.03 & 0.14 & 0.33 \\
\hline Time $\times$ Cs & 1,239 & 0.44 & 0.02 & 0.04 & $4.25^{*}$ \\
\hline
\end{tabular}

Table 3. F-values of linear mixed effects models on the effect of litter species diversity (LD), time of exposure (Time) and leaf litter species identity [Cecropia andina (CA), Dictyocaryum lamarckianum (DL), Myrcia pubescens (MP), Cavendishia zamorensis (CZ), Graffenrieda emarginata (GE) and Clusia spp. (Cs)] on the abundance of Collembola, Oribatida, Mesostigmata and Prostigmata. F-values represent those where the respective factor was fitted first. Significant effects are given in bold $(* \mathrm{P}<0.05 ; * * \mathrm{P}<0.01 ; * * * \mathrm{P}<0.001)$; df, degrees of freedom.

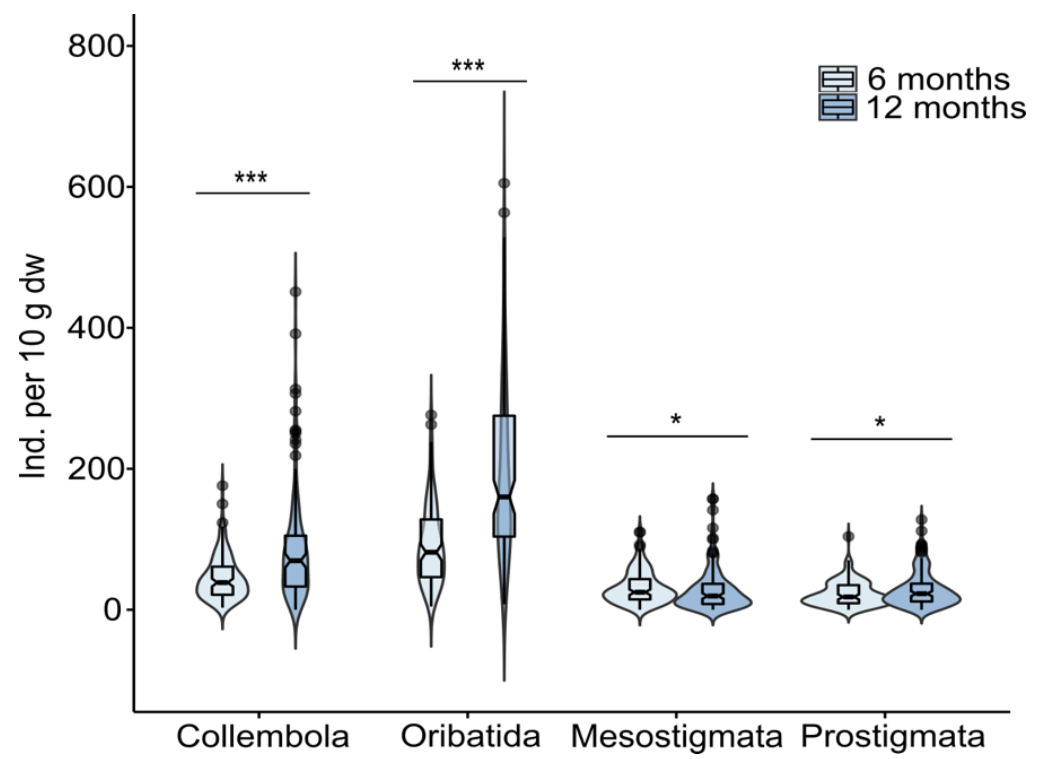

Figure 2. Abundance of Collembola, Oribatida, Mesostigmata and Prostigmata in litterbags after 6 and 12 months of incubation in the field. Boxplots show medians and quantiles for each date of exposure. Violin plots illustrate kernel probability density. $* * * \mathrm{P}<0.001 ; * \mathrm{P}<0.05$. 


\section{Discussion}

\section{Litter diversity}

Contrary to our first hypothesis, $\mathrm{C}_{\text {mic }}$ decreased rather than increased with increasing litter diversity after one year of exposure in the field (Figure 1). Leaves of tropical forest trees are of low nutritional quality and contain high concentrations of structural compounds and secondary metabolites, typically higher than those in trees of temperate forests (Coley and Barone 1996; Hallam and Read 2006; Cárdenas et al. 2015). Secondary metabolites, particularly polyphenols known to suppress microorganisms by inhibiting enzyme activity (Hättenschwiler and Vitousek 2000; Hoorens et al. 2003), are important drivers of decomposition processes particularly in tropical rainforests (Coq et al. 2010). Potentially, secondary compounds, such as polyphenols, detrimentally affected litter microorganisms in a systemic way resulting in a decrease in $\mathrm{C}_{\text {mic }}$, thereby resulting in a negative complementarity effect in leaf litter mixtures (Chomel et al. 2016; Ristok et al. 2019). The fact that $\mathrm{BR}, q \mathrm{O}_{2}$ and $+\mathrm{C}_{\text {Slope }}$ were not significantly affected by litter diversity suggests that higher leaf litter diversity does not necessarily result in an increase in the availability of nutrient and carbon resources in this tropical rainforest. Rather, the results suggest that litter diversity increases the exposure of microorganisms to secondary leaf litter compounds, detrimentally affecting their activity. Due to the preferential decay of labile litter compounds, the concentration of secondary compounds as well as recalcitrant structural compounds, such as lignin, may increase during litter decomposition, thereby reducing litter decomposition at later stages of litter decay, as has previously been suggested for litter at our study sites (Butenschoen et al. 2014; Marian et al. 2017).

Similar to $\mathrm{C}_{\mathrm{mic}}, \mathrm{M}_{\text {loss }}$ significantly increased in single litter species treatments after one year of exposure underscoring the correlation between (Table 2). Changes in the chemical composition of litter material throughout the decomposition process alter the structure and functioning of microbial communities and thus affect the rate at which litter material is decomposed (Berg and McClaugherty 2008). Notably, $\mathrm{M}_{\text {loss }}$ increased with litter diversity after 6 months of exposure, however, the effect was no longer present after 12 months. Presumably, this reflects reliance of the early microbial community on labile litter 
compounds, which were more abundant in leaf litter mixtures (Pérez Harguindeguy et al. 2008; Rinkes et al. 2014). However, as decomposition proceeded, the remaining more recalcitrant compounds accumulated and their decomposition was independent of litter diversity.

In contrast to $\mathrm{C}_{\mathrm{mic}}$ and $\mathrm{M}_{\text {loss}}$, the abundance of microarthropods was not affected by litter diversity (Table 3). Some previous studies found mixtures to promote the abundance of microarthropods (Migge et al. 1998; Hansen 2000; Hättenschwiler and Gasser 2005; Schädler and Brandl 2005), while others did not find evidence that litter diversity beneficially affects microarthropods (Scheu et al. 2003; Ilieva-Makulec et al. 2006; Korboulewsky et al. 2016; Bluhm et al. 2019; Patoine et al. 2020). Our results agree with the latter findings and support the results of Marian et al. (2018) suggesting that litter diversity in this tropical rainforest neither improves habitat conditions nor the availability of resources for microarthropods, at least during early stages of decomposition. Indeed, detritivore microarthropods are considered to comprise predominantly generalist feeders colonizing a range of forest types and therefore are rather insensitive to changes caused by litter mixing (Wardle et al. 2006; Ball et al. 2014; Gergócs and Hufnagel 2016; Patoine et al. 2020). However, even though litter diversity did not affect microarthropod abundance, it may still have fostered the diversity of microarthropods, as has been shown for other soil organisms, such as testate amoebae at our study site (Krashevska et al. 2017).

\section{Exposure time}

Generally, $\mathrm{M}_{\text {loss }}$ increased with time parallel to microbial parameters. Litter decomposition at our study site can be divided into three phases, with the early phase lasting for about 12 months (Marian et al. 2017). This early phase of decomposition is characterized by the loss of labile $\mathrm{C}$ compounds via leaching and by the growth of opportunistic microorganisms that form new soluble compounds (Berg and McClaugherty 2008), and this likely explains the close link between $\mathrm{M}_{\text {loss }}$ and microbial activity and growth (Table 2). However, contrary to our second hypothesis, the increase in $q \mathrm{O}_{2}$ values between 6 and 12 months of exposure indicates that microorganisms increasingly suffered from stress conditions later during 
exposure. Stress conditions result in less efficient use of $\mathrm{C}$ compounds and increased investment into maintenance metabolism (Yan et al. 2003; Ndaw et al. 2009). Presumably, toward the end of the early litter decomposition stage microorganisms increasingly competed for resources as easily decomposable leaf litter compounds vanished (Fontaine et al. 2003; Poll et al. 2008; Rinkes et al. 2011). The parallel increase in the $+\mathrm{C}_{\text {Slope }}$ with time suggests that this was associated with less efficient nutrient capture by microorganisms pointing towards a switch from predominant limitation by nutrients early during exposure to the limitation by easily available carbon resources later (Sall et al. 2003; Laganière et al. 2010). Early stages of litter decay in the studied tropical montane rainforest might be associated with high abundance of mycorrhizal fungi (Marian et al. 2017). The C input that mycorrhizal fungi obtain from plants may allow them to efficiently compete with saprotrophic fungi for nutrients, even though their enzymatic capability is typically inferior to that of saprotrophic fungi (Hodge et al. 2001; Camenzind and Rillig 2013). Indeed, the assumption that mycorrhizal and saprotrophic fungi interact antagonistically early during litter decomposition at our study site is supported by earlier studies (Marian et al. 2019; Sánchez-Galindo et al. 2019).

Parallel to microbial parameters, the abundance of all microarthropod taxa studied increased with time, with the exception of Mesostigmata. Mesostigmata commonly hunt in the litter for other microarthropods, particularly Collembola, Astigmata and weakly sclerotized Oribatida (Koehler 1997; Schneider and Maraun 2009). Although variations in the abundance of Mesostigmata were closely linked to the abundance of Collembola and Oribatida (Table 2), the fact that their abundance decreased with time likely reflect that Mesostigmata in the litterbags were not only feeding on microarthropods, but also on other organisms, presumably Nematoda, insect larvae and eggs. Indeed, some species of Mesostigmata may preferentially colonize certain microhabitats to hunt for prey such as Nematoda (Klarner et al. 2013; Heidemann et al. 2014).

The increase in the abundance of the microarthropod decomposers Collembola and Oribatida with time indicates that changes during the initial stages of decomposition influence both groups in a similar way. Surprisingly, Collembola and Oribatida abundance 
was not closely associated with microbial biomass (Table 2) even though microorganisms are their major food resource (Maraun et al. 2003; Scheu et al. 2005; Dhooria 2016). Rather, the stage of litter decomposition within the early decomposition phase (i.e., 6 vs 12 months), appears to be the more important driver of the abundance of microarthropod decomposers. Indeed, litter material that is highly colonized by microorganisms becomes more palatable for microarthropods (Bardgett 2005; Das and Joy 2009), which at least in part is due to the reduction in plant secondary compounds such as phenols (Coulis et al. 2009; Asplund et al. 2013). Overall, our results support earlier findings at this study site in that the role of litter resources for the nutrition of decomposer microarthropods increases with litter decomposition (Marian et al. 2018). Moreover, the parallel increase in the abundance of Prostigmata suggests that the increase in the abundance of decomposer microarthropod prey benefitted higher trophic levels.

\section{Leaf litter identity}

The presence of specific plant leaf litter species in mixtures might increase or decrease the rate at which the litter decomposes (Hector et al. 2000; Hoorens et al. 2003, 2010). Variation can be attributed predominantly to differences in litter quality among the component species in mixtures (Gartner and Cardon 2004; Hättenschwiler et al. 2005). Indeed, litter decomposition and colonization of the litter by microarthropods in our study were related to the initial chemical composition of the litter species. Our third hypothesis was supported by the beneficial effects of high-quality $C$. andina litter. Presence of this litter species significantly decreased $q \mathrm{O}_{2}$ values and increased the abundance of Collembola and Prostigmata. C. andina had high initial $\mathrm{N}$ and $\mathrm{P}$ concentrations, and low lignin content (see Appendix 1), providing readily available nutrients, reducing nutrient stress for microorganisms and thereby contributing to an increase in $\mathrm{C}_{\text {mic }}$. Increased microbial $\mathrm{C}$ use efficiency may also have resulted from a shift in microbial community composition toward high-energy-efficient species (Dilly and Munch 1996), e.g. from opportunistic bacteria to fungi able to break down complex litter compounds (Chapman et al. 2013). Changes in microbial community composition probably were driven by increasing concentrations of recalcitrant litter compounds favoring saprotrophic fungi able to degrade these compounds, 
which in turn beneficially affected decomposers, such as Collembola and Oribatida, feeding on these fungi and the litter materials degraded by them.

The high $q \mathrm{O}_{2}$ and the $+\mathrm{C}_{\text {slope }}$ values after 12 months of exposure reflected the low quality of D. lamarckianum, C. zamorensis and G. emarginata litter, and presumable scarcity of easily accessible $\mathrm{C}$ resources to microorganisms. All these litter species were characterized by low initial $\mathrm{N}$ and $\mathrm{P}$ concentrations, and high concentrations of lignin and cellulose (Appendix 1). The concentrations of lignin and cellulose serve as indicator of litter quality and as predictor of litter decomposition (Fioretto et al. 2005; Berg 2014). Cellulose not entrapped in lignin degrades rapidly during early stages of decomposition and this contributes to the release of $\mathrm{N}$ and $\mathrm{P}$, typical elements limiting microbial growth (Berg and McClaugherty 2008; Hobbie et al. 2012; Berg 2014). However, during this stage, labile compounds are commonly used by opportunistic microorganisms (Cornelissen et al. 1999; Fioretto et al. 2005), impeding the growth of microorganism able to degrade recalcitrant litter compounds (Ilieva-Makulec et al. 2006). Therefore, by the end of the early stage of litter decomposition, structural compounds become relatively more abundant and reduce resource quality, which differentially affects microorganisms and microarthropods, as indicated by the lower abundance of Collembola in litter of C.zamorensis and $D$. lamarckianum. Interestingly, the decrease in $\mathrm{C}_{\text {mic }}$ after 12 months in litterbags containing G. emarginata was associated with high abundance of decomposer microarthropods, suggesting that there is no close relationship between decomposer microarthropods and bulk microbial biomass in litter. This conclusion is also supported by the lack of significant correlations between $\mathrm{C}_{\mathrm{mic}}$ and decomposer microarthropod abundances (Table 2).

The correlation between the abundance of Collembola and Oribatida and litter $\mathrm{M}_{\text {loss }}$ presumably reflects that these microarthropods benefited from both higher quality litter and by microorganisms colonizing the litter at later stages of decay. The significant negative correlation between Collembola abundance and litter C-to-N ratio (Table 2) indicates that Collembola heavily rely on litter quality. However, contrary to our fourth hypothesis, the differential responses of microarthropods to litter species suggests that leaf litter chemical composition alone is insufficient to explain variations in the abundance of soil 
microarthropods, as has been suggested in earlier studies (Kaneko and Salamanca 1999; González and Seastedt 2001; Hoorens et al. 2010). This is most strongly supported by the greater abundance of Oribatida in litterbags containing Clusia spp. litter, which was of particular low quality. This indicates that physical litter characteristics such as toughness and structure, might play a more important role in driving soil microarthropod abundance than litter chemistry and the degree of microbial colonization.

\section{Conclusions}

The results of our study showed that higher levels of litter diversity may negatively affect soil microbial biomass and mass loss in the studied tropical montane rainforest, presumably due to the accumulation of recalcitrant compounds and the generally low quality of the leaf litter material. Notably, the response of microbial parameters and microarthropod abundance to litter identity was more pronounced than to litter diversity, with the differential responses of soil biota to litter identity in part being due to differences in the initial chemical composition of litter species. Generally, the results indicate that both microarthropods and microorganisms benefit from larger amounts of easily available litter resources during early stages of decomposition, highlighting the importance of litter quality as driver of the abundance and activity of decomposer organisms. However, the results also indicate that litter traits, related to the physical structure of litter may be more important to decomposer invertebrates than litter chemistry and gross microbial characteristics of litter such as microbial biomass. Overall, our findings indicate that litter species identity functions as major driver of the abundance and activity of soil organisms, and thereby exert distinct effects on ecosystem processes such as decomposition and nutrient mobilization.

\section{Acknowledgments}

We thank the Deutsche Forschungsgemeinschaft (DFG; FOR816) for financial support. Further, we thank the Ministerio de Ambiente del Ecuador and the Universidad Técnico Particular de Loja (UTPL) for the research permits and the center Naturaleza y Cultura Internacional (NCI) for access to the San Francisco reserve. We thank student helpers for 
the establishment of the experiment in the field and Christina Lucas for her help in the laboratory.

\section{References}

Allen SE, Grimshaw HM, Parkinson JA, Quarmby C (1974) Chemical analysis of ecological materials. Blackwell Scientific Publications. Oxford, UK

Anderson JPE, Domsch KH (1978) A physiological method for the quantitative measurement of microbial biomass in soils. Soil Biol Biochem 10:215-221

Asplund J, Bokhorst S, Wardle DA (2013) Secondary compounds can reduce the soil microarthropod effect on lichen decomposition. Soil Biol Biochem 66:10-16

Ball BA, Carrillo Y, Molina M (2014) The influence of litter composition across the litter-soil interface on mass loss, nitrogen dynamics and the decomposer community. Soil Biol Biochem 69:71-82

Bardgett RD (2005) The Biology of soils: A community and ecosystem approach. Oxford University Press

Bardgett RD, Shine A (1999) Linkages between plant litter diversity, soil microbial biomass and ecosystem function in temperate grasslands. Soil Biol Biochem 31:317-321

Beck E, Ritcher M (2008) Ecological aspects of a biodiversity hotspot in the Andes of southern Ecuador. Biodivers Ecol Ser 2:195-217

Beck T, Joergensen RG, Kandeler E, et al (1997) An inter-laboratory comparison of ten different ways of measuring soil microbial biomass C. Soil Biol Biochem 29:1023-1032

Bendix J, Homeier J, Cueva Ortiz E, et al (2006) Seasonality of weather and tree phenology in a tropical evergreen mountain rain forest. Int J Biometeorol 50:370-384

Berg B (2014) Decomposition patterns for foliar litter - A theory for influencing factors. Soil Biol Biochem 78:222-232

Berg B, Berg MP, Bottner P, et al (1993) Litter mass loss rates in pine forests of Europe and Eastern United States: some relationships with climate and litter quality. Biogeochemistry 20:127-159 
Berg B, McClaugherty C (2008) Plant litter, Second ed. Springer-Verlag Berlin Heidelberg

Bluhm C, Butenschoen O, Maraun M, Scheu S (2019) Effects of root and leaf litter identity and diversity on oribatid mite abundance, species richness and community composition. PLoS One $14: 1-16$

Brehm G, Fiedler K (2005) Diversity and community structure of geometrid moths of disturbed habitat in a montane area in the Ecuadorian Andes. J Res Lepid 1999:1-14

Brehm G, Homeier J, Fiedler K, et al (2008) Mountain rain forests in southern Ecuador as a hotspot of biodiversity - limited knowledge and diverging patterns. In: Beck E, Bendix J, Kottke I, et al. (eds) Gradients in a Tropical Mountain Ecosystem of Ecuador. Ecological Studies (Analysis and Synthesis). pp 15-23

Butenschoen O, Krashevska V, Maraun M, et al (2014) Litter mixture effects on decomposition in tropical montane rainforests vary strongly with time and turn negative at later stages of decay. Soil Biol Biochem 77:121-128

Camenzind T, Rillig MC (2013) Extraradical arbuscular mycorrhizal fungal hyphae in an organic tropical montane forest soil. Soil Biol Biochem 64:96-102

Cárdenas RE, Hättenschwiler S, Valencia R, et al (2015) Plant herbivory responses through changes in leaf quality have no effect on subsequent leaf-litter decomposition in a neotropical rain forest tree community. New Phytol 207:817-829

Chapman SK, Newman GS, Hart SC, et al (2013) Leaf litter mixtures alter microbial community development: Mechanisms for non-additive effects in litter decomposition. PLoS One 8:

Chomel M, Guittonny-Larchevêque M, Fernandez C, et al (2016) Plant secondary metabolites: a key driver of litter decomposition and soil nutrient cycling. J Ecol 104:1527-1541

Coley PD, Barone JA (1996) Herbivory and Plant Defenses in Tropical Forests. Annu Rev Ecol Syst 27:305-335

Coq S, Souquet JM, Meudec E, et al (2010) Interspecific variation in leaf litter tannins drives decomposition in a tropical rain forest of French Guiana. Ecology 91:2080-2091

Cornelissen JHC, Pérez-Harguindeguy N, Díaz S, et al (1999) Leaf structure and defence control litter decomposition rate across species and life forms in regional floras on two continents. 
New Phytol 143:191-200

Coulis M, Hättenschwiler S, Rapior S, Coq S (2009) The fate of condensed tannins during litter consumption by soil animals. Soil Biol Biochem 41:2573-2578

Coûteaux MM, Bottner P, Berg B (1995) Litter decomposition, climate and litter quality. Tree 10:63-66

Das S, Joy VC (2009) Chemical quality impacts of tropical forest tree leaf litters on the growth and fecundity of soil Collembola. Eur J Soil Biol 45:448-454

Demoling F, Figueroa D, Bååth E (2007) Comparison of factors limiting bacterial growth in different soils. Soil Biol Biochem 39:2485-2495

Dhooria MS (2016) Soil mites. In: Fundamentals of Applied Acarology. Springer, Singapore, pp $197-206$

Dilly O, Munch JC (1996) Microbial biomass content, basal respiration and enzyme activities during the course of decomposition of leaf litter in a black alder (Alnus glutinosa (L.) Gaertn.) forest. Soil Biol Biochem 28:1073-1081

Eissfeller V, Langenbruch C, Jacob A, et al (2013) Tree identity surpasses tree diversity in affecting the community structure of oribatid mites (Oribatida) of deciduous temperate forests. Soil Biol Biochem 63:154-162

Fioretto A, Di Nardo C, Papa S, Fuggi A (2005) Lignin and cellulose degradation and nitrogen dynamics during decomposition of three leaf litter species in a Mediterranean ecosystem. Soil Biol Biochem 37:1083-1091

Fontaine S, Mariotti A, Abbadie L (2003) The priming effect of organic matter: A question of microbial competition? Soil Biol Biochem 35:837-843

Gartner T, Cardon Z (2004) Decomposition dynamics in mixed-species leaf litter. Oikos 104:230-246

Gergócs V, Hufnagel L (2016) The effect of microarthropods on litter decomposition depends on litter quality. Eur J Soil Biol 75:24-30

Gessner MO, Swan CM, Dang CK, et al (2010) Diversity meets decomposition. Trends Ecol Evol $25: 372-380$ 
González G, Seastedt TR (2001) Soil fauna and plant litter decomposition in tropical and subalpine forests. Ecology 82:955-964

Hallam A, Read J (2006) Do tropical species invest more in anti-herbivore defence than temperate species? A test in Eucryphia (Cunoniaceae) in eastern Australia. J Trop Ecol 22:41-51

Handa IT, Aerts R, Berendse F, et al (2014) Consequences of biodiversity loss for litter decomposition across biomes. Nature 509:218-221

Hansen RA (2000) Effects of habitat complexity and composition on a diverse litter microarthropod assemblage. Ecology 81:1120-1132

Hansen RA, Coleman DC (1998) Litter complexity and composition are determinants of the diversity and species composition of oribatid mites (Acari: Oribatida) in litterbags. Appl Soil Ecol 9:17-23

Hättenschwiler S (2005) Effects of tree species diversity on litter quality and decomposition. In: Scherer-Lorenzen M, Körner C, Schulze E-D (eds) Forest diversity and function: Temperate and boreal systems. Springer Nature Switzerland, pp 149-164

Hättenschwiler S, Gasser P (2005) Soil animals alter plan litter diversity effects on decomposition. Proc Natl Acad Sci 102:1519-1524

Hättenschwiler S, Tiunov A V., Scheu S (2005) Biodiversity and litter decomposition in terrestrial ecosystems. Annu Rev Ecol Evol Syst 36:191-218

Hättenschwiler S, Vitousek PM (2000) The role of polyphenols in terrestrial ecosystem nutrient cycling. Tree 15:238-242

Hector A, Beale AJ, Minns A, et al (2000) Consequences of the reduction of plant diversity for litter decomposition: Effects through litter quality and microenvironment. Oikos 90:357-371

Heidemann K, Ruess L, Scheu S, Maraun M (2014) Nematode consumption by mite communities varies in different forest microhabitats as indicated by molecular gut content analysis. Exp Appl Acarol 64:49-60

Hobbie SE, Eddy WC, Buyarski CR, et al (2012) Response of decomposing litter and its microbial community to multiple forms of nitrogen enrichment. Ecol Monogr 82:389-405

Hodge A, Campbell CD, Fitter AH (2001) An arbuscular mycorrhizal fungus accelerates 
decomposition and achqires nitrogen directly from organic material. Nature 413:297-299

Homeier J, Breckle S, Günter S, et al (2010) Tree diversity, forest structure and productivity along altitudinal and topographical gradients in a species-rich Ecuadorian montane rain forest. Biotropica 42:140-148

Homeier J, Werner FA, Gradstein SR, et al (2008) Potential vegetation and floristic composition of Andean forests in south Ecuador, with a focus on the RBSF. In: Beck E, Bendix J, Kottke I, et al. (eds) Gradients in a Tropical Mountain Ecosystem of Ecuador. Springer, Berlin, Heidelberg, pp 87-100

Hoorens B, Aerts R, Stroetenga M (2003) Does initial litter chemistry explain litter mixture effects on decomposition? Oecologia 137:578-586

Hoorens B, Coomes D, Aerts R (2010) Neighbour identity hardly affects litter-mixture effects on decomposition rates of New Zealand forest species. Oecologia 162:479-489

Ilieva-Makulec K, Olejniczak I, Szanser M (2006) Response of soil micro- and mesofauna to diversity and quality of plant litter. Eur J Soil Biol 42:244-249

Illig J, Schatz H, Scheu S, Maraun M (2008) Decomposition and colonization by microarthropods of two litter types in a tropical montane rain forest in southern Ecuador. $J$ Trop Ecol 24:157-167

Kaneko N, Salamanca EF (1999) Mixed leaf litter effects on decomposition rates and soil microarthropod communities in an oak-pine stand in Japan. Ecol Res 14:131-138

Kempson D, Lloyd M, Ghelardi R (1963) A new extractor for woodland litter. Pedobiologia 3:121

Klarner B, Maraun M, Scheu S (2013) Trophic diversity and niche partitioning in a species rich predator guild - Natural variations in stable isotope ratios $(13 \mathrm{C} / 12 \mathrm{C}, 15 \mathrm{~N} / 14 \mathrm{~N})$ of mesostigmatid mites (Acari, Mesostigmata) from Central European beech forests. Soil Biol Biochem 57:327-333

Klironomos JN, Widden P, Deslandes I (1992) Feeding preferences of the collembolan Folsomia candida in relation to microfungal successions on decaying litter. Soil Biol Biochem 24:685692 
Koehler HH (1997) Mesostigmata (Gamasina, Uropodina), efficient predators in agroecosystems. Agric Ecosyst Environ 62:105-117

Korboulewsky N, Perez G, Chauvat M (2016) How tree diversity affects soil fauna diversity: A review. Soil Biol Biochem 94:94-106

Krashevska V, Maraun M, Ruess L, Scheu S (2010) Carbon and nutrient limitation of soil microorganisms and microbial grazers in a tropical montane rain forest. Oikos 119:1020-1028

Krashevska V, Sandmann D, Marian F, et al (2017) Leaf litter chemistry drives the structure and composition of soil Testate Amoeba communities in a tropical montane rainforest of the Ecuadorian Andes. Microb Ecol 74:681-690

Laganière J, Paré D, Bradley RL (2010) How does a tree species influence litter decomposition? Separating the relative contribution of litter quality, litter mixing, and forest floor conditions. Can J For Res 40:465-475

Macfadyen A (1961) Improved funnel-type extractors for soil arthropods. J Anim Ecol 30:171184

Makkonen M, Berg MP, Handa IT, et al (2012) Highly consistent effects of plant litter identity and functional traits on decomposition across a latitudinal gradient. Ecol Lett 15:1033-1041

Maraun M, Illig J, Sandmann D, et al (2008) Soil Fauna. In: Beck E, Bendix J, Kottke I, et al. (eds) Gradients in a tropical mountain ecosystem of Ecuador. Springer, Berlin, Heidelberg, pp 181-192

Maraun M, Martens H, Migge S, et al (2003) Adding to "the enigma of soil animal diversity": Fungal feeders and saprophagous soil invertebrates prefer similar food substrates. Eur J Soil Biol 39:85-95

Marian F, Brown L, Sandmann D, et al (2019) Roots, mycorrhizal fungi and altitude as determinants of litter decomposition and soil animal communities in tropical montane rainforests. Plant Soil 438:1-18

Marian F, Sandmann D, Krashevska V, et al (2017) Leaf and root litter decomposition is discontinued at high altitude tropical montane rainforests contributing to carbon sequestration. Ecol Evol 7:6432-6443 
Marian F, Sandmann D, Krashevska V, et al (2018) Altitude and decomposition stage rather than litter origin structure soil microarthropod communities in tropical montane rainforests. Soil Biol Biochem 125:263-274

Migge S, Maraun M, Scheu S, Schaefer M (1998) The oribatid mite community (Acarina) of pure and mixed stands of beech (Fagus sylvatica) and spruce (Picea abies) of different age. Appl Soil Ecol 9:115-121

Moser G, Hertel D, Leuschner C (2007) Altitudinal change in LAI and stand leaf biomass in tropical montane forests: A transect study in ecuador and a pan-tropical meta-analysis. Ecosystems 10:924-935

Myers N, Mittermeier R, Mittermeier C, et al (2000) Biodiversity hotspots for conservation priorities. Nature 403:853-858

Ndaw SM, Gama-Rodrigues AC, Gama-Rodrigues EF, et al (2009) Relationships between bacterial diversity, microbial biomass, and litter quality in soils under different plant covers in northern Rio de Janeiro State, Brazil. Can J Microbiol 55:1089-1095

Patoine G, Bruelheide H, Haase J, et al (2020) Tree litter functional diversity and nitrogen concentration enhance litter decomposition via changes in earthworm communities. Ecol Evol $10: 6752-6768$

Paulsch A, Müller-Hohenstein K (2008) Bird Species Distribution Along an Altitudinal Gradient in Southern Ecuador and its Functional Relationships with Vegetation Structure. In: Beck E, Bendix J, Kottke I, et al. (eds) Gradients in a tropical mountain ecosystem of Ecuador. Springer-Verlag Berlin Heidelberg, pp 149-156

Pérez Harguindeguy N, Blundo CM, Gurvich DE, et al (2008) More than the sum of its parts? Assessing litter heterogeneity effects on the decomposition of litter mixtures through leaf chemistry. Plant Soil 303:151-159

Poll C, Marhan S, Ingwersen J, Kandeler E (2008) Dynamics of litter carbon turnover and microbial abundance in a rye detritusphere. Soil Biol Biochem 40:1306-1321

R Core Team (2014) R: A language and environment for statistical computing. http://www.rproject.org/

Rinkes ZL, DeForest JL, Grandy AS, et al (2014) Interactions between leaf litter quality, particle 
size, and microbial community during the earliest stage of decay. Biogeochemistry 117:153168

Rinkes ZL, Weintraub MN, DeForest JL, Moorhead DL (2011) Microbial substrate preference and community dynamics during decomposition of Acer saccharum. Fungal Ecol 4:396-407

Ristok C, Leppert KN, Scherer-Lorenzen M, et al (2019) Soil macrofauna and leaf functional traits drive the decomposition of secondary metabolites in leaf litter. Soil Biol Biochem $135: 429-437$

Ruess L, Lussenhop J (2005) Trophic interactions of fungi and animals. In: Dighton J, Oudemans $\mathrm{P}$, White J (eds) The fungal community: its organization and role in the ecosystem. CRC, Boca Raton, pp 581-598

Sall SN, Masse D, Bernhard-Reversat F, et al (2003) Microbial activities during the early stage of laboratory decomposition of tropical leaf litters: The effect of interactions between litter quality and exogenous inorganic nitrogen. Biol Fertil Soils 39:103-111

Sánchez-Galindo LM, Camenzind T, Maraun M, Scheu S (2019) Impacts of core rotation, defaunation and nitrogen addition on arbuscular mycorrhizal fungi, microorganisms and microarthropods in a tropical montane rainforest. Trop Ecol 60:350-361

Schädler M, Brandl R (2005) Do invertebrate decomposers affect the disappearance rate of litter mixtures? Soil Biol Biochem 37:329-337

Schaefer M (2018) Brohmer-Fauna von Deutschland, 25th edn. Quelle und Meyer. Wiebelsheim

Scheu S (1992) Automated measurement of the respiratory response of soil microcompartments: Active microbial biomass in earthworm faeces. Soil Biol Biochem 24:1113-1118

Scheu S, Albers D, Alphei J, et al (2003) The soil fauna community in pure and mixed stands of beech and spruce of different age: Trophic structure and structuring forces. Oikos 101:225238

Scheu S, Ruess L, Bonkowski M (2005) Interactions and soil micro- and mesofauna. In: Buscot F, Varma A (eds) Microorganisms in soils: roles in genesis and functions. pp 253-275

Schmid B, Baruffo M, Wang Z, Niklaus PA (2017) A guide to analyzing biodiversity experiments. J Plant Ecol 10:91-110 
Schmid B, Hector A, Huston M, et al (2002) The design and analysis of biodiversity experiments. In: Loreau M, Naeem S, Inchausti P (eds) Biodiversity and ecosystem functioning: synthesis and perspectives. Oxford University Press, pp 61-78

Schneider K, Maraun M (2005) Feeding preferences among dark pigmented fungal taxa ("Dematiacea") indicate limited trophic niche differentiation of oribatid mites (Oribatida, Acari). Pedobiologia 49:61-67

Schneider K, Maraun M (2009) Top-down control of soil microarthropods - Evidence from a laboratory experiment. Soil Biol Biochem 41:170-175

Seastedt TR (1984) The role of microarthropods in decomposition and mineralization processes. Annu Rev Entomol Vol 29 25-46

Trogisch S, He JS, Hector A, Scherer-Lorenzen M (2016) Impact of species diversity, stand age and environmental factors on leaf litter decomposition in subtropical forests in China. Plant Soil 400:337-350

Vos VCA, van Ruijven J, Berg MP, et al (2011) Macro-detritivore identity drives leaf litter diversity effects. Oikos 120:1092-1098

Wardle DA, Yeates GW, Barker GM, Bonner KI (2006) The influence of plant litter diversity on decomposer abundance and diversity. Soil Biol Biochem 38:1052-1062

Wullaert H, Pohlert T, Boy J, et al (2009) Spatial throughfall heterogeneity in a montane rain forest in Ecuador: Extent, temporal stability and drivers. J Hydrol 377:71-79

Yan T, Yang L, Campbell CD (2003) Microbial biomass and metabolic quotient of soils under different land use in the Three Gorges Reservoir area. Geoderma 115:129-138 


\section{Appendix}

Appendix 1. Initial chemical composition of the litter species used in the experiment. The analyses were performed in triplicate using bulk samples. Data are given in percentages of dry mass; nd = not detected.

\begin{tabular}{ccccccc}
\hline & $\begin{array}{c}\text { Cecropia } \\
\text { andina }\end{array}$ & $\begin{array}{c}\text { Dictyocaryum } \\
\text { lamarckianum }\end{array}$ & $\begin{array}{c}\text { Myrcia } \\
\text { pubescens }\end{array}$ & $\begin{array}{c}\text { Cavendishia } \\
\text { zamorensis }\end{array}$ & $\begin{array}{c}\text { Graffenrieda } \\
\text { emarginata }\end{array}$ & Clusia spp. \\
\hline $\mathbf{C}$ & $39.30 \pm 3.65$ & $41.25 \pm 1.70$ & $39.61 \pm 3.65$ & $41.74 \pm 0.01$ & $40.28 \pm 1.68$ & $42.80 \pm 3.65$ \\
$\mathbf{N}$ & $1.08 \pm 0.02$ & $0.73 \pm 0.01$ & $0.60 \pm 0.02$ & $0.50 \pm 0.01$ & $0.40 \pm 0.16$ & $0.40 \pm 0.02$ \\
C-to-N & $36.29 \pm 2.91$ & $58.59 \pm 1.25$ & $65.64 \pm 4.62$ & $84.64 \pm 0.01$ & $91.29 \pm 1.68$ & $107.21 \pm 6.00$ \\
Lignin & $46.67 \pm 6.37$ & $52.40 \pm 9.83$ & $50.53 \pm 9.07$ & $51.73 \pm 13.95$ & $42.60 \pm 8.40$ & $63.93 \pm 10.10$ \\
Cellulose & $29.60 \pm 6.28$ & $40.73 \pm 4.29$ & $35.80 \pm 7.27$ & $39.53 \pm 3.33$ & $40.40 \pm 6.73$ & $13.00 \pm 3.37$ \\
Al & $1.88 \pm 0.65$ & $0.14 \pm 0.08$ & $0.18 \pm 0.06$ & $0.23 \pm 0.02$ & $2.41 \pm 0.33$ & $0.13 \pm 0.01$ \\
Ca & $17.32 \pm 0.82$ & $1.13 \pm 0.08$ & $1.07 \pm 0.02$ & $6.11 \pm 0.83$ & $1.07 \pm 0.02$ & $3.07 \pm 0.82$ \\
Fe & $2.03 \pm 0.05$ & $1.18 \pm 0.02$ & $0.29 \pm 0.08$ & $0.09 \pm 0.03$ & $0.30 \pm 0.03$ & $0.06 \pm 0.02$ \\
K & $3.05 \pm 0.01$ & $0.37 \pm 0.09$ & $1.23 \pm 0.09$ & $1.08 \pm 0.01$ & $1.08 \pm 0.03$ & $1.65 \pm 0.09$ \\
Mg & $3.22 \pm 0.73$ & $1.25 \pm 0.09$ & $1.22 \pm 0.09$ & $1.72 \pm 0.09$ & $1.72 \pm 0.09$ & $1.55 \pm 0.09$ \\
Mn & $0.11 \pm 0.01$ & $0.31 \pm 0.03$ & $0.14 \pm 0.09$ & $0.06 \pm 0.01$ & $0.26 \pm 0.09$ & $0.48 \pm 0.09$ \\
Na & nd & $0.03 \pm 0.02$ & $0.30 \pm 0.02$ & nd & nd & nd \\
P & $0.48 \pm 0.08$ & $0.21 \pm 0.08$ & $0.22 \pm 0.10$ & $0.27 \pm 0.10$ & $0.12 \pm 0.08$ & $0.25 \pm 0.08$ \\
\hline
\end{tabular}


Appendix 2. Means of microbial parameters $\left(\mathrm{C}_{\text {mic }}\right.$, microbial biomass carbon; $\mathrm{BR}$, basal respiration, $q \mathrm{O}_{2}$, microbial specific respiration; $+\mathrm{C}_{\text {slope }}$, the slopes of microbial growth after C addition). LD, litter diversity (LD1, one species; LD2, two species; LD4, four species); CA, Cecropia andina; DL, Dictyocaryum lamarckianum; MP, Myrcia pubescens; CZ, Cavendishia zamorensis; GE, Graffenrieda emarginata; Cs, Clusia spp. Values are means $\pm \mathrm{SD}$.

\begin{tabular}{|c|c|c|c|c|c|c|}
\hline & & & $\begin{array}{c}\mathrm{C}_{\text {mic }} \\
{\left[\mathrm{mg} \mathrm{C}_{\text {mic }} \mathrm{g}^{-1} \mathrm{dw}\right]}\end{array}$ & $\begin{array}{c}\text { BR } \\
{\left[\mu \mathrm{l} \mathbf{O}_{2} \mathbf{m g}^{-1} \mathbf{C}_{\text {mic }} \mathbf{h}^{-1}\right]}\end{array}$ & $\begin{array}{c}q \mathbf{O}_{2} \\
{\left[\mu l \mathbf{O}_{2} \mathbf{m g}^{-1} \mathbf{C}_{\text {mic }} \mathbf{h}^{-1}\right]}\end{array}$ & + CSlope \\
\hline LD & & & $\begin{array}{l}13.30 \pm 8.99 \\
11.01 \pm 9.74 \\
10.10 \pm 6.12 \\
\end{array}$ & $\begin{array}{c}154.57 \pm 97.62 \\
152.42 \pm 105.28 \\
138.35 \pm 79.27 \\
\end{array}$ & $\begin{array}{l}12.97 \pm 5.55 \\
14.78 \pm 5.71 \\
14.27 \pm 4.22\end{array}$ & $\begin{array}{l}0.0113 \pm 0.0208 \\
0.0066 \pm 0.0111 \\
0.0084 \pm 0.0121 \\
\end{array}$ \\
\hline Time & \multicolumn{2}{|c|}{$\begin{array}{l}6 \text { months } \\
12 \text { months }\end{array}$} & $\begin{array}{c}8.28 \pm 4.19 \\
13.62 \pm 10.18 \\
\end{array}$ & $\begin{array}{c}101.7 \pm 19.5 \\
191.1 \pm 114.0 \\
\end{array}$ & $\begin{array}{l}12.90 \pm 2.21 \\
15.65 \pm 6.56\end{array}$ & $\begin{array}{l}0.0042 \pm 0.0035 \\
0.0117 \pm 0.0190 \\
\end{array}$ \\
\hline CA & \multicolumn{2}{|c|}{$\begin{array}{l}\text { Presence } \\
\text { Absence }\end{array}$} & $\begin{array}{l}11.12 \pm 6.22 \\
10.81 \pm 9.56\end{array}$ & $\begin{array}{l}148.50 \pm 94.82 \\
144.73 \pm 91.97\end{array}$ & $\begin{array}{l}13.50 \pm 4.18 \\
14.90 \pm 5.65\end{array}$ & $\begin{array}{l}0.0089 \pm 0.0157 \\
0.0075 \pm 0.0114\end{array}$ \\
\hline DL & \multicolumn{2}{|c|}{$\begin{array}{l}\text { Presence } \\
\text { Absence }\end{array}$} & $\begin{array}{l}10.58 \pm 6.98 \\
11.28 \pm 9.20\end{array}$ & $\begin{array}{l}150.09 \pm 89.94 \\
143.14 \pm 96.06 \\
\end{array}$ & $\begin{array}{l}14.74 \pm 4.06 \\
13.85 \pm 5.82 \\
\end{array}$ & $\begin{array}{l}0.0097 \pm 0.0140 \\
0.0067 \pm 0.0130\end{array}$ \\
\hline MP & \multicolumn{2}{|c|}{$\begin{array}{l}\text { Presence } \\
\text { Absence }\end{array}$} & $\begin{array}{l}10.53 \pm 9.53 \\
11.29 \pm 6.97 \\
\end{array}$ & $\begin{array}{c}133.07 \pm 69.40 \\
157.33 \pm 107.72 \\
\end{array}$ & $\begin{array}{l}14.15 \pm 4.14 \\
14.37 \pm 5.75 \\
\end{array}$ & $\begin{array}{l}0.0074 \pm 0.0104 \\
0.0088 \pm 0.0156 \\
\end{array}$ \\
\hline $\mathbf{C Z}$ & \multicolumn{2}{|c|}{ Presence } & $\begin{array}{l}10.33 \pm 8.53 \\
11.54 \pm 7.89\end{array}$ & $\begin{array}{l}143.71 \pm 89.58 \\
149.02 \pm 96.61\end{array}$ & $\begin{array}{l}14.94 \pm 5.75 \\
13.63 \pm 4.27\end{array}$ & $\begin{array}{l}0.0065 \pm 0.0117 \\
0.0097 \pm 0.0149\end{array}$ \\
\hline GE & \multicolumn{2}{|c|}{$\begin{array}{l}\text { Presence } \\
\text { Absence }\end{array}$} & $\begin{array}{l}10.31 \pm 6.80 \\
11.46 \pm 9.17 \\
\end{array}$ & $\begin{array}{l}141.93 \pm 94.72 \\
149.98 \pm 91.98 \\
\end{array}$ & $\begin{array}{l}14.34 \pm 5.10 \\
14.21 \pm 5.08 \\
\end{array}$ & $\begin{array}{l}0.0079 \pm 0.0121 \\
0.0084 \pm 0.0146 \\
\end{array}$ \\
\hline Cs & \multicolumn{2}{|c|}{$\begin{array}{l}\text { Presence } \\
\text { Absence }\end{array}$} & $\begin{array}{l}10.36 \pm 6.53 \\
11.42 \pm 9.33 \\
\end{array}$ & $\begin{array}{l}142.19 \pm 90.71 \\
149.78 \pm 95.13 \\
\end{array}$ & $\begin{array}{l}14.32 \pm 5.05 \\
14.24 \pm 5.12 \\
\end{array}$ & $\begin{array}{l}0.0080 \pm 0.0101 \\
0.0083 \pm 0.0157\end{array}$ \\
\hline \multicolumn{7}{|c|}{ Time $\times$ LD } \\
\hline LD1 & \multicolumn{2}{|c|}{$\begin{array}{l}6 \text { months } \\
12 \text { months }\end{array}$} & $\begin{array}{c}7.79 \pm 1.85 \\
18.81 \pm 9.92\end{array}$ & $\begin{array}{c}96.07 \pm 18.97 \\
213.06 \pm 109.53 \\
\end{array}$ & $\begin{array}{l}12.65 \pm 2.50 \\
13.29 \pm 7.53\end{array}$ & $\begin{array}{l}0.0045 \pm 0.0031 \\
0.0182 \pm 0.0280 \\
\end{array}$ \\
\hline LD 2 & \multicolumn{2}{|c|}{$\begin{array}{l}6 \text { months } \\
12 \text { months }\end{array}$} & $\begin{array}{c}8.03 \pm 1.71 \\
13.97 \pm 13.06\end{array}$ & $\begin{array}{c}103.05 \pm 19.08 \\
201.79 \pm 130.59\end{array}$ & $\begin{array}{l}13.03 \pm 1.91 \\
16.53 \pm 7.48\end{array}$ & $\begin{array}{l}0.0041 \pm 0.0036 \\
0.0091 \pm 0.0149\end{array}$ \\
\hline LD 4 & \multicolumn{2}{|c|}{$\begin{array}{l}6 \text { months } \\
12 \text { months }\end{array}$} & $\begin{array}{c}8.67 \pm 5.94 \\
11.52 \pm 6.01\end{array}$ & $\begin{array}{l}102.47 \pm 20.01 \\
174.23 \pm 98.28\end{array}$ & $\begin{array}{l}12.86 \pm 2.38 \\
15.69 \pm 5.11\end{array}$ & $\begin{array}{c}0.0043 \pm \\
0.0036 \\
0.0126 \pm 0.0158\end{array}$ \\
\hline \multicolumn{7}{|c|}{ Time $\times$ Litter identity } \\
\hline \multirow{2}{*}{ CA } & $\begin{array}{l}\text { Presence } \\
\text { Absence }\end{array}$ & $\begin{array}{l}6 \text { months } \\
6 \text { months }\end{array}$ & $\begin{array}{l}8.64 \pm 1.66 \\
7.99 \pm 5.44\end{array}$ & $\begin{array}{l}103.19 \pm 19.44 \\
100.50 \pm 19.58\end{array}$ & $\begin{array}{l}12.12 \pm 2.00 \\
13.53 \pm 2.20\end{array}$ & $\begin{array}{l}0.0037 \pm 0.0044 \\
0.0047 \pm 0.0026\end{array}$ \\
\hline & $\begin{array}{l}\text { Presence } \\
\text { Absence }\end{array}$ & $\begin{array}{l}12 \text { months } \\
12 \text { months }\end{array}$ & $\begin{array}{c}13.61 \pm 7.91 \\
13.63 \pm 11.76 \\
\end{array}$ & $\begin{array}{l}193.81 \pm 116.56 \\
188.97 \pm 112.63 \\
\end{array}$ & $\begin{array}{l}14.89 \pm 5.23 \\
16.27 \pm 7.46 \\
\end{array}$ & $\begin{array}{l}0.0142 \pm 0.0206 \\
0.0104 \pm 0.0155 \\
\end{array}$ \\
\hline \multirow{2}{*}{ DL } & $\begin{array}{l}\text { Presence } \\
\text { Absence }\end{array}$ & $\begin{array}{l}6 \text { months } \\
6 \text { months }\end{array}$ & $\begin{array}{l}8.25 \pm 5.81 \\
8.31 \pm 1.79 \\
\end{array}$ & $\begin{array}{l}103.55 \pm 19.70 \\
100.05 \pm 19.29\end{array}$ & $\begin{array}{l}13.62 \pm 2.31 \\
12.24 \pm 1.92 \\
\end{array}$ & $\begin{array}{l}0.0044 \pm 0.0034 \\
0.0041 \pm 0.0037\end{array}$ \\
\hline & $\begin{array}{l}\text { Presence } \\
\text { Absence }\end{array}$ & $\begin{array}{l}12 \text { months } \\
12 \text { months }\end{array}$ & $\begin{array}{c}12.90 \pm 7.31 \\
14.29 \pm 12.21\end{array}$ & $\begin{array}{l}196.63 \pm 107.35 \\
186.23 \pm 120.22\end{array}$ & $\begin{array}{l}15.86 \pm 5.04 \\
15.45 \pm 7.71\end{array}$ & $\begin{array}{c}0.0151 \pm 0.0180 \\
0.0094 \pm 0.017\end{array}$ \\
\hline MP & $\begin{array}{l}\text { Presence } \\
\text { Absence }\end{array}$ & $\begin{array}{l}6 \text { months } \\
6 \text { months }\end{array}$ & $\begin{array}{c}8.27 \pm 5.94 \\
8.29 \pm 1.74\end{array}$ & $\begin{array}{c}98.27 \pm 16.49 \\
104.52 \pm 21.33\end{array}$ & $\begin{array}{l}13.03 \pm 2.36 \\
12.79 \pm 2.10\end{array}$ & $\begin{array}{l}0.0041 \pm 0.0033 \\
0.0043 \pm 0.0038\end{array}$ \\
\hline
\end{tabular}




\begin{tabular}{|c|c|c|c|c|c|c|}
\hline & Presence & 12 months & $12.80 \pm 11.71$ & $167.88 \pm 83.56$ & $15.27 \pm 5.14$ & $0.0106 \pm 0.0136$ \\
& Absence & 12 months & $14.30 \pm 8.76$ & $210.15 \pm 131.38$ & $15.96 \pm 7.56$ & $0.0133 \pm 0.0209$ \\
\hline \multirow{4}{*}{ CZ } & Presence & 6 months & $8.07 \pm 1.52$ & $103.63 \pm 18.99$ & $12.98 \pm 1.81$ & $0.0039 \pm 0.0028$ \\
& Absence & 6 months & $8.48 \pm 5.68$ & $99.88 \pm 19.92$ & $12.82 \pm 2.56$ & $0.0046 \pm 0.0041$ \\
\cline { 2 - 7 } & Presence & 12 months & $12.59 \pm 11.57$ & $183.80 \pm 112.03$ & $16.91 \pm 7.45$ & $0.0092 \pm 0.0160$ \\
& Absence & 12 months & $14.60 \pm 8.61$ & $198.16 \pm 116.24$ & $14.44 \pm 5.38$ & $0.0149 \pm 0.0194$ \\
\hline \multirow{4}{*}{ GE } & Presence & 6 months & $9.03 \pm 5.98$ & $105.82 \pm 20.97$ & $12.71 \pm 2.31$ & $0.0039 \pm 0.0031$ \\
& Absence & 6 months & $7.69 \pm 1.62$ & $98.45 \pm 17.71$ & $13.04 \pm 2.14$ & $0.0045 \pm 0.0038$ \\
\cline { 2 - 7 } & Presence & 12 months & $11.58 \pm 7.37$ & $178.04 \pm 122.51$ & $15.98 \pm 6.45$ & $0.0119 \pm 0.0159$ \\
& Absence & 12 months & $15.23 \pm 11.74$ & $201.52 \pm 106.48$ & $15.39 \pm 6.68$ & $0.0122 \pm 0.0196$ \\
\hline \multirow{6}{*}{ Cs } & Presence & 6 months & $8.40 \pm 6.07$ & $99.02 \pm 21.32$ & $12.88 \pm 2.48$ & $0.0056 \pm 0.0042$ \\
\cline { 2 - 7 } & Absence & 12 months & $8.18 \pm 1.60$ & $103.83 \pm 17.76$ & $12.91 \pm 1.99$ & $0.0032 \pm 0.0026$ \\
& Presence & 6 months & $12.32 \pm 6.44$ & $185.36 \pm 11.16$ & $15.75 \pm 6.41$ & $0.0105 \pm 0.0133$ \\
\cline { 2 - 7 } & Absence & 12 months & $14.65 \pm 12.31$ & $195.73 \pm 116.75$ & $15.57 \pm 6.72$ & $0.0133 \pm 0.0210$ \\
\hline
\end{tabular}


Appendix 3. Means of microarthropod abundance. Values are means \pm SD. For legend see Appendix 2.

\begin{tabular}{|c|c|c|c|c|c|c|}
\hline & & & $\begin{array}{l}\text { Collembola } \\
{\left[\text { ind. } 10 \mathrm{~g}^{-1}\right]}\end{array}$ & $\begin{array}{l}\text { Oribatida } \\
\text { [ind. } 10 \mathrm{~g}^{-1} \text { ] }\end{array}$ & $\begin{array}{l}\text { Mesostigmata } \\
\text { [ind. } 10 \mathrm{~g}^{-1} \text { ] }\end{array}$ & $\begin{array}{l}\text { Prostigmata } \\
\text { [ind. } 10 \mathrm{~g}^{-1} \text { ] }\end{array}$ \\
\hline \multirow{3}{*}{ LD } & \multicolumn{2}{|c|}{1} & $73 \pm 79$ & $132 \pm 116$ & $26 \pm 24$ & $22 \pm 18$ \\
\hline & \multicolumn{2}{|c|}{$\begin{array}{l}1 \\
2\end{array}$} & $71 \pm 67$ & $150 \pm 128$ & $32 \pm 29$ & $26 \pm 23$ \\
\hline & \multicolumn{2}{|c|}{4} & $67 \pm 91$ & $147 \pm 113$ & $30 \pm 26$ & $27 \pm 23$ \\
\hline \multirow{2}{*}{ Time } & \multirow{2}{*}{\multicolumn{2}{|c|}{$\begin{array}{l}6 \text { months } \\
12 \text { months }\end{array}$}} & $46 \pm 31$ & $90 \pm 55$ & $32 \pm 23$ & $22 \pm 17$ \\
\hline & & & $93 \pm 104$ & $201 \pm 137$ & $29 \pm 30$ & $29 \pm 26$ \\
\hline \multirow{2}{*}{$\mathbf{C A}$} & \multirow{2}{*}{\multicolumn{2}{|c|}{$\begin{array}{l}\text { Presence } \\
\text { Absence }\end{array}$}} & $83 \pm 99$ & $141 \pm 117$ & $33 \pm 27$ & $29 \pm 22$ \\
\hline & & & $58 \pm 59$ & $150 \pm 121$ & $28 \pm 27$ & $23 \pm 22$ \\
\hline \multirow{2}{*}{ DL } & \multicolumn{2}{|c|}{ Presence } & $52 \pm 37$ & $141 \pm 106$ & $30 \pm 27$ & $25 \pm 23$ \\
\hline & \multicolumn{2}{|c|}{ Absence } & $85 \pm 103$ & $150 \pm 130$ & $30 \pm 27$ & $27 \pm 22$ \\
\hline \multirow{2}{*}{ MP } & \multicolumn{2}{|c|}{ Presence } & $71 \pm 98$ & $144 \pm 125$ & $30 \pm 28$ & $24 \pm 22$ \\
\hline & \multicolumn{2}{|c|}{ Absence } & $69 \pm 63$ & $147 \pm 114$ & $30 \pm 26$ & $27 \pm 22$ \\
\hline \multirow{2}{*}{$\mathrm{CZ}$} & \multicolumn{2}{|c|}{ Presence } & $53 \pm 35$ & $132 \pm 95$ & $26 \pm 21$ & $25 \pm 23$ \\
\hline & \multicolumn{2}{|c|}{ Absence } & $85 \pm 105$ & $159 \pm 137$ & $34 \pm 31$ & $27 \pm 22$ \\
\hline \multirow{2}{*}{ GE } & \multicolumn{2}{|c|}{ Presence } & $80 \pm 99$ & $162 \pm 118$ & $34 \pm 29$ & $28 \pm 24$ \\
\hline & \multicolumn{2}{|c|}{ Absence } & $62 \pm 61$ & $133 \pm 119$ & $27 \pm 25$ & $24 \pm 20$ \\
\hline \multirow{2}{*}{ Cs } & \multicolumn{2}{|c|}{ Presence } & $75 \pm 104$ & $163 \pm 138$ & $30 \pm 28$ & $27 \pm 23$ \\
\hline & \multicolumn{2}{|c|}{ Absence } & $65 \pm 56$ & $131 \pm 99$ & $30 \pm 26$ & $25 \pm 22$ \\
\hline \multicolumn{7}{|c|}{ Time $\times$ LD } \\
\hline D1 & $6 \mathrm{~m}$ & nths & $35 \pm 24$ & $76 \pm 59$ & $27 \pm 23$ & $18 \pm 13$ \\
\hline LDI & $12 n$ & inths & $111 \pm 96$ & $189 \pm 132$ & $25 \pm 25$ & $26 \pm 22$ \\
\hline & $6 \mathrm{~m}$ & nths & $47 \pm 35$ & $93 \pm 53$ & $32 \pm 26$ & $21 \pm 14$ \\
\hline LD 2 & $12 n$ & inths & $94 \pm 82$ & $207 \pm 154$ & $32 \pm 32$ & $32 \pm 28$ \\
\hline & $6 \mathrm{~m}$ & nths & $48 \pm 29$ & $93 \pm 57$ & $33 \pm 21$ & $25 \pm 21$ \\
\hline LD 4 & $12 n$ & nths & $87 \pm 123$ & $200 \pm 128$ & $27 \pm 31$ & $28 \pm 25$ \\
\hline Time $\times 1$ & r identity & & & & & \\
\hline & Presence & 6 months & $56 \pm 34$ & $88 \pm 54$ & $37 \pm 26$ & $28 \pm 20$ \\
\hline$C$ & Absence & 6 months & $37 \pm 26$ & $92 \pm 57$ & $27 \pm 20$ & $17 \pm 15$ \\
\hline CA & Presence & 12 months & $111 \pm 131$ & $193 \pm 137$ & $28 \pm 28$ & $30 \pm 24$ \\
\hline & Absence & 12 months & $78 \pm 74$ & $208 \pm 140$ & $29 \pm 32$ & $28 \pm 27$ \\
\hline & Presence & 6 months & $44 \pm 30$ & $90 \pm 56$ & $33 \pm 25$ & $23 \pm 20$ \\
\hline DI & Absence & 6 months & $47 \pm 32$ & $91 \pm 55$ & $30 \pm 21$ & $21 \pm 15$ \\
\hline DL & Presence & 12 months & $60 \pm 42$ & $192 \pm 119$ & $27 \pm 28$ & $26 \pm 25$ \\
\hline & Absence & 12 months & $123 \pm 132$ & $209 \pm 154$ & $30 \pm 33$ & $32 \pm 27$ \\
\hline & Presence & 6 months & $43 \pm 27$ & $87 \pm 48$ & $30 \pm 20$ & $22 \pm 20$ \\
\hline MD & Absence & 6 months & $48 \pm 34$ & $93 \pm 61$ & $33 \pm 25$ & $22 \pm 15$ \\
\hline $\mathbf{M P}$ & Presence & 12 months & $98 \pm 131$ & $201 \pm 151$ & $31 \pm 35$ & $26 \pm 24$ \\
\hline & Absence & 12 months & $89 \pm 77$ & $201 \pm 129$ & $27 \pm 27$ & $32 \pm 27$ \\
\hline & Presence & 6 months & $44 \pm 30$ & $85 \pm 54$ & $28 \pm 20$ & $21 \pm 16$ \\
\hline$C 7$ & Absence & 6 months & $47 \pm 32$ & $96 \pm 57$ & $34 \pm 26$ & $23 \pm 19$ \\
\hline $\mathrm{CZ}$ & Presence & 12 months & $62 \pm 38$ & $179 \pm 103$ & $23 \pm 22$ & $28 \pm 27$ \\
\hline & Absence & 12 months & $124 \pm 135$ & $222 \pm 163$ & $34 \pm 37$ & $30 \pm 24$ \\
\hline GE & Presence & 6 months & $50 \pm 34$ & $102 \pm 61$ & $35 \pm 22$ & $25 \pm 20$ \\
\hline
\end{tabular}


Chapter 2

\begin{tabular}{|c|c|c|c|c|c|c|}
\hline \multirow{6}{*}{} & Absence & 6 months & $42 \pm 29$ & $81 \pm 49$ & $29 \pm 23$ & $20 \pm 15$ \\
\cline { 2 - 7 } & Presence & 12 months & $109 \pm 131$ & $221 \pm 130$ & $33 \pm 35$ & $32 \pm 28$ \\
& Absence & 12 months & $81 \pm 76$ & $185 \pm 144$ & $25 \pm 26$ & $27 \pm 24$ \\
\hline \multirow{6}{*}{ Cs } & Presence & 6 months & $45 \pm 27$ & $100 \pm 57$ & $30 \pm 19$ & $21 \pm 17$ \\
& Absence & 6 months & $46 \pm 34$ & $82 \pm 53$ & $33 \pm 26$ & $23 \pm 18$ \\
\cline { 2 - 7 } & Presence & 12 months & $106 \pm 138$ & $226 \pm 165$ & $31 \pm 33$ & $33 \pm 26$ \\
& Absence & 12 months & $84 \pm 66$ & $181 \pm 111$ & $27 \pm 27$ & $27 \pm 25$ \\
\hline
\end{tabular}


Appendix 4. Abundance of Collembola as affected by the presence of leaf litter species [Cecropia andina (CA), Dictyocaryum lamarckianum (DL), Myrcia pubescens (MP), Graffenrieda emarginata (GE), Cavendishia zamorensis (CZ) and Clusia spp. (Cs)]. Boxplots show medians and quantiles of Collembola abundance for presence and absence of each leaf litter species. Violin plots illustrate kernel probability density. ${ }^{* * *} \mathrm{P}<0.001$; $* * \mathrm{P}<0.01$.

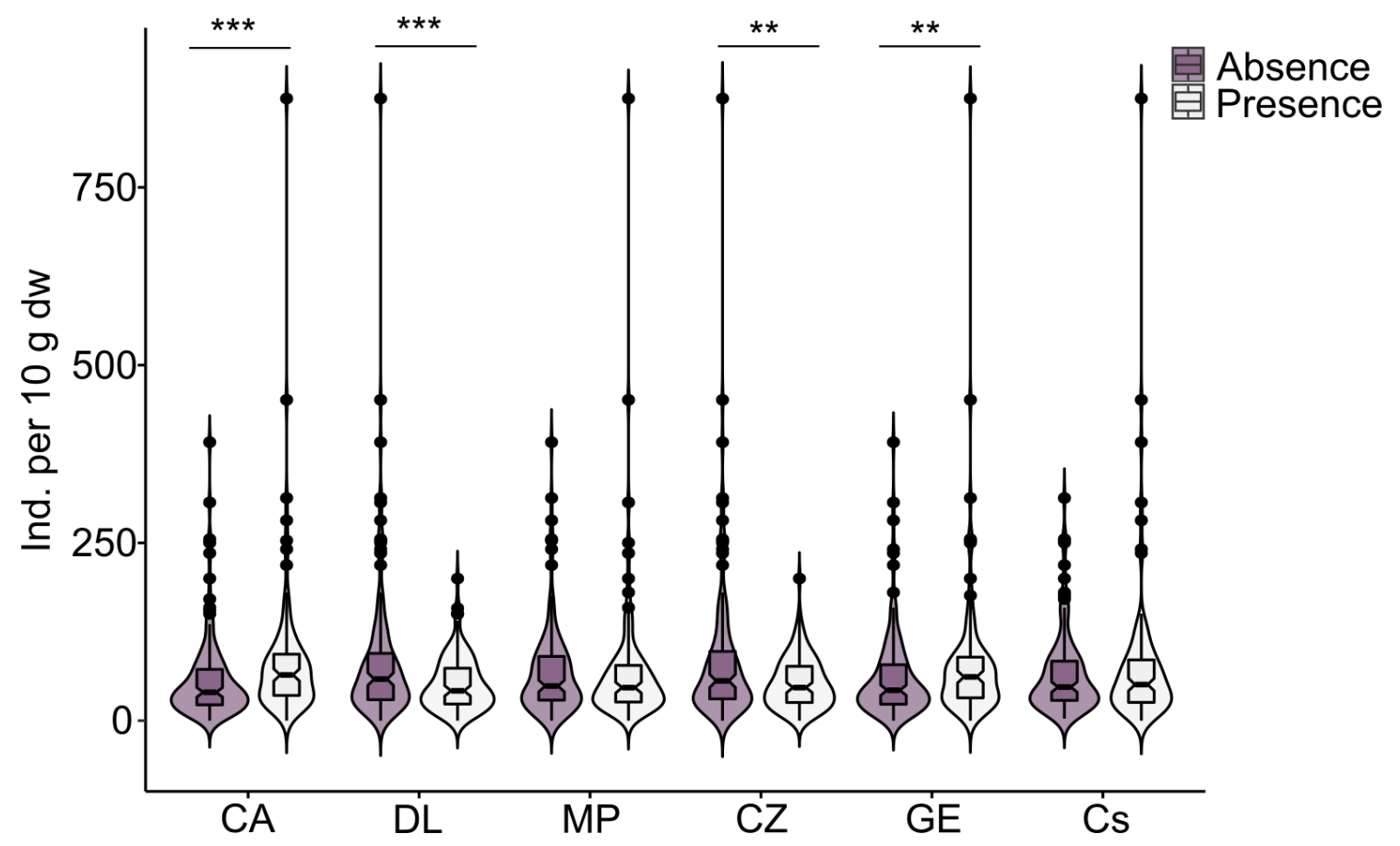


Chapter 3

Differences in leaf and root litter decomposition are mediated by soil microorganisms not decomposer

\section{microarthropods in tropical montane rainforests}

Laura M. Sánchez-Galindo, Dorothee Sandmann, Franca Marian, Tobias Lauermann,

Mark Maraun \& Stefan Scheu.
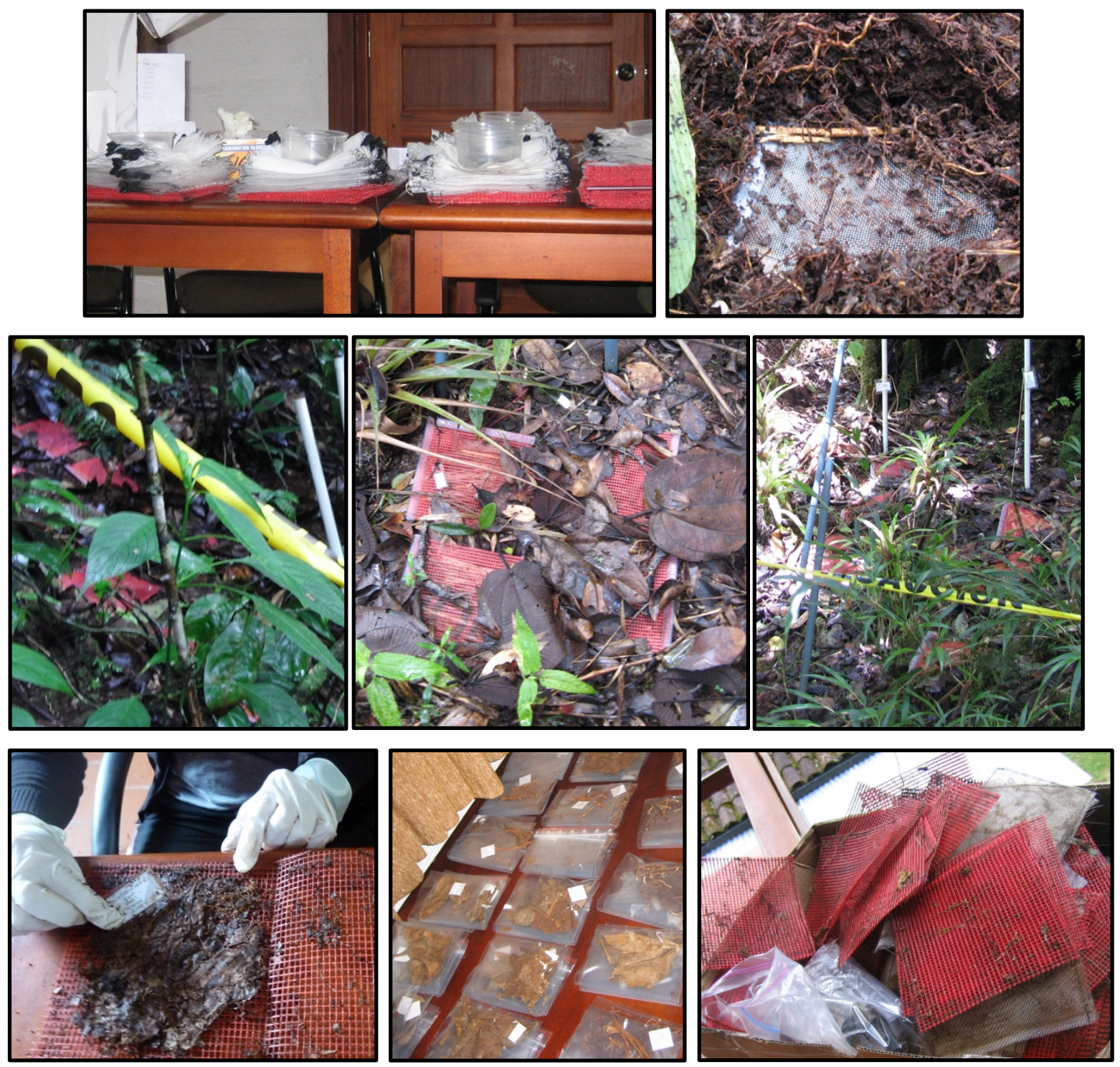


\section{Abstract}

Plant litter decomposition is a key process in carbon and nutrient cycling. Among the factors determining litter decomposition rates, the role of soil biota for the decomposition of different plant litter types and its modification by variations in climatic conditions is not well understood. In this study we used litterbags with different mesh size $(45 \mu \mathrm{m}, 1 \mathrm{~mm}$ and $4 \mathrm{~mm}$ ) to investigate the effect of microorganisms and decomposer microarthropods on leaf and root litter decomposition along an altitudinal gradient of a tropical montane rainforest in Ecuador. We examined decomposition rates, litter $\mathrm{C}$ and $\mathrm{N}$ concentrations, microbial biomass and activity, as well as decomposer microarthropod abundance, with a focus on oribatid mites (Oribatida, Acari) over one year of exposure at three different altitudes (1000, 2000 and $3000 \mathrm{~m}$ ). Leaf litter mass loss did not differ between the 1000 and $2000 \mathrm{~m}$ sites, while root litter mass loss decreased with increasing altitude. These changes in litter decomposition rates were paralleled by changes in microbial biomass and activity. Access of the litterbags by microarthropods ( 1 and $4 \mathrm{~mm}$ mesh size) did not affect leaf litter mass loss, whereas in root litter mass loss increased significantly at $3000 \mathrm{~m}$ with the access of soil microarthropods ( $4 \mathrm{~mm}$ mesh size). In both leaf and root litter Oribatida community composition varied with altitude and litter C-to-N ratio. The result suggest that the impacts of climatic conditions differentially affect the decomposition of leaf and root litter and these modifications are modulated by the quality of the local litter material. These findings also highlight the dominance of litter quality as dominant force structuring Oribatida communities. Overall, the results support the view that decomposition processes in montane rainforests are mostly driven by microorganisms with soil microarthropods playing a more important role for the decomposition of litter material of low-quality.

Keywords: Acari; Collembola; Litterbags; Mesh size; Microbial biomass. 


\section{Introduction}

Dead leaves and roots comprise the major plant litter material that enters the belowground system and represent the main energy resource for soil organisms (Berg and McClaugherty 2008). Although the annual input of leaf and root litter in forests are typically equivalent in mass (Norby et al. 2004; Freschet et al. 2013), most studies investigating effects of soil organisms on plant litter decay focus on leaves, overlooking the potential of roots as a food resource and regulator of carbon and nutrient cycling (García-Palacios et al. 2016; Fujii and Takeda 2017). Therefore, integration of both root litter and leaf litter is needed for a comprehensive understanding of the role of soil animals in element cycling and ecosystem functioning.

Leaf and root litter material differ in structure and chemical composition (Berg and McClaugherty 2008). Generally, roots contain higher concentrations of recalcitrant compounds compared to leaves, which inhibits degradation by soil organisms and this is assumed to be the reason for the slower decay rates of roots compared to leaves (Hobbie et al. 2010; Freschet et al. 2012; García-Palacios et al. 2016; Jo et al. 2016). Additionally, leaf and root litter are located at different positions in the forest floor. Leaf litter is deposited on top of the soil, while root litter enters the decomposer system directly within the soil. These different locations generate different input pathways of nutrients and are associated with different microenvironments for soil organisms (Ostertag and Hobbie 1999; Fujii and Takeda 2010, 2017). Differences in quality and input pathways of litter type are likely to affect the abundance, composition and activity of soil organisms, with knock-on effects for decomposition rates and soil nutrient dynamics.

Effects of soil organisms on litter decomposition not only change with litter traits, but also with climatic conditions (Coûteaux et al. 1995; Aerts 1997; Hättenschwiler et al. 2005). In tropical Andean montane ecosystems, considered a biodiversity hotspot, climatic conditions change strongly with altitude (Myers et al. 2000; Beck and Ritcher 2008). Increasing altitude is associated with a decline in litter nutrient concentrations and increase in the thickness of organic layers and fine root biomass (diameter $<2 \mathrm{~mm}$ ) (Tanner et al. 1998; Soethe et al. 2007; Graefe et al. 2008). Notably, at higher altitudes, more organic material originates from fine root litter than from fallen leaves (Röderstein et al. 2005). 
Such changes in litter traits with environmental conditions affect the nutrient supply for decomposer organisms and thereby likely control the abundance and diversity of soil decomposer species (Wang et al. 2010; García-Palacios et al. 2016). However, few studies have investigated the impacts of litter traits and altitudinal changes in climate on soil animal communities and their role in leaf and root litter decomposition in tropical montane rainforest ecosystems (Marian et al. 2017, 2018).

Decomposer communities in tropical montane rainforests are dominated by microorganisms and soil microarthropods (Illig et al. 2008; Maraun et al. 2008; Scheu et al. 2008). Among soil microarthropods, oribatid mites (Oribatida, Acari) and springtails (Collembola, Insecta) are the most abundant and diverse organisms (Seastedt 1984; Ruess and Lussenhop 2005). These microarthropods increase rates of litter decomposition and nutrient cycling in forest ecosystems either via the consumption of litter or through stimulation of microbial activity and transport of microbial propagules (Swift et al. 1979; Seastedt 1984; Ruess and Lussenhop 2005). However, interactions between microorganisms, microarthropods and litter type are not well understood. Nonetheless, the exclusion of specific faunal size classes from litter has demonstrated the importance of particular groups of soil organisms on litter decomposition rates (Bradford et al. 2002; Joo et al. 2006; Kampichler and Bruckner 2009). Such experiments are crucial for identifying the role of different animal communities for litter decomposition.

The present study investigates how the effects of microorganisms and decomposer microarthropods on leaf and root litter decomposition vary along an altitudinal gradient of tropical montane rainforests in Ecuador. Decomposition rates, microbial biomass and respiration, as well as decomposer microarthropod abundance, with focus on Oribatida, were studied over one year using litterbags with different mesh sizes to control access by soil fauna to the litter. We hypothesized that (1) the decomposition of litter, regardless of litter type, decreases with increasing altitude due to less favourable abiotic conditions with increasing altitude. Since litter decomposition in the study area is mainly due to the action of microorganisms (Illig et al. 2008; Marian et al. 2017), we hypothesized that (2) limiting the access of litter by microarthropods accelerates decomposition by increasing microbial biomass and activity in both leaf and root litter, with the effect being stronger at higher 
altitudes where nutrients are more limited. Further, we hypothesized that (3) the abundance of decomposer microarthropods and the diversity of Oribatida is higher in leaf than in root litter irrespective of altitude and increase with increasing microbial biomass. Lastly, we hypothesized that (4) the role of litter quality in structuring Oribatida communities declines with time, with the effect being less pronounced in root than in leaf litter.

\section{Materials and methods}

\section{Study area}

The study area is located in the northern fringes of the Podocarpus National Park in the eastern slopes of the Andean Cordillera, Southeast Ecuador. Three study sites at 1000, 2000 , and $3000 \mathrm{~m}$ a.s.l. represent an altitudinal gradient with moderately steep slopes of

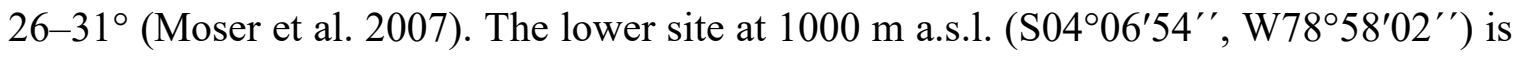
located in the Río Bombuscaro valley and classified as evergreen submontane rainforest dominated by tree species of the families Arecaceae, Combretaceae, Moraceae, Monimiaceae, Rubiaceae, and Sapotaceae (Homeier et al. 2008). The intermediate site at $2000 \mathrm{~m}$ a.s.1. (S3 ${ }^{\circ} 8^{\prime} 18^{\prime \prime}$, W79 $\left.4^{\prime} 45^{\prime \prime}\right)$ is located in the Reserva Biológica San Francisco on the north-facing flank of the Río San Francisco valley and consists of an evergreen lower montane rainforest dominated by trees of the families Arecaceae, Clusiaceae, Ericaceae, Lauraceae, Melastomataceae and Rubiaceae (Homeier et al. 2008). The highest site at $3000 \mathrm{~m}$ a.s.1. (S04 $06^{\prime} 711^{\prime \prime}$, W79 $\left.10^{\prime} 58^{\prime \prime}\right)$ is located near the upper Cajanuma mountain at the northwest gate of Podocarpus National Park. The forest has been classified as evergreen elfin forest dominated by trees / shrubs of the families Aquifoliaceae, Bromeliaceae, Chloranthaceae, Clusiaceae, Ericaceae and Melastomataceae (Homeier et al. 2008). The climate is semi-humid with an average annual temperature of $14.9{ }^{\circ} \mathrm{C}, 12 .{ }^{\circ} \mathrm{C}$ and $8.9{ }^{\circ} \mathrm{C}$ and annual precipitation of approximately 2200, 3500 and $4500 \mathrm{~mm}$ at 1000, 2000 and $3000 \mathrm{~m}$ a.s.1., respectively (Bendix et al. 2006; Homeier et al. 2010). Soil types of the study sites are alumic Acrisol (1000 m), Gley Cambisol (2000 m) and Podzol (3000 m) (Soethe et al. 2006; Moser et al. 2007). The thickness of organic soil layers increases with altitude from $4.8 \mathrm{~cm}$ at $1000 \mathrm{~m}$ to $30.5 \mathrm{~cm}$ at $2000 \mathrm{~m}$ to $43.5 \mathrm{~cm}$ at $3000 \mathrm{~m}$ (Leuschner et al. 2007; 
Graefe et al. 2008). In parallel, fine root biomass increases from 2.7 to 6.2 to $10.8 \mathrm{t} \mathrm{ha}^{-1}$ at the respective sites (Soethe et al. 2006).

\section{Experimental design}

Nylon litterbags ( $17 \times 17 \mathrm{~cm}$ ) of mesh sizes of $45 \mu \mathrm{m}, 1 \mathrm{~mm}$ and $4 \mathrm{~mm}$ were filled with 10 $\mathrm{g}$ of leaf or root litter. Leaf litterbags consisted of a mixture of freshly fallen leaves of three local abundant tree species of each study site: Pouteria sp., Cecropia andina and Mollinedia sp. at $1000 \mathrm{~m}$, Graffenrieda emarginata, Clusia sp. and Cavendishia zamorensis at $2000 \mathrm{~m}$, Clusia sp. Graffenrieda emarginata and Hedyosmum sp. at $3000 \mathrm{~m}$. For root litterbags, the roots were collected by hand from the upper $20-30 \mathrm{~cm}$ of the soil/organic layer of respective sites and consisted of a mixture of three size classes: Small $(<1 \mathrm{~mm}$ diameter), medium (1-2 $\mathrm{mm}$ diameter) and large ( $>3 \mathrm{~mm}$ diameter). The amount of individual leaf species and root size classes placed in the litterbags was chosen to resemble their amount in the litter layer and soil, respectively (see Appendix 1). The collected leaves and roots were gently rinsed with tap water to clear them from adhering soil and dried at $60^{\circ} \mathrm{C}$.

Litterbags were placed in the field in October 2008 (end of the rainy season). Bags containing leaf litter were randomly placed on top of the litter layer and fixed with nails, while those containing root litter were placed approximately $5 \mathrm{~cm}$ below the litter layer. Three blocks were established at each of the three altitudes with a minimum distance between blocks of $20 \mathrm{~m}$. Two replicates of each treatment were placed in each block, with one replicate retrieved after 6 months and the other after 12 months.

After retrieval, the litter material in each litterbag was divided into two parts of equal mass. The first half was analysed for dry mass, microbial biomass, basal respiration, and $\mathrm{C}$ and $\mathrm{N}$ concentrations. From the second half, Oribatida and Collembola were extracted using a modified high-gradient heat extractor (Macfadyen 1961; Kempson et al. 1963) and counted. Adult Oribatida were identified to species level or sorted into morphospecies (Balogh and Balogh 1990, 2002), following the nomenclature of Subías (2018). All identified species are recorded in Ecotaxonomy database (Potapov et al. 2019). 


\section{Analytical procedures}

Mass loss $\left(\mathrm{M}_{\text {loss }}\right)$ for both leaves and roots was calculated as $M_{\text {loss }}=$ $\left(\left(m_{0}-m_{1} / m_{0}\right)\right) \times 100$, with $m_{0}$ the dry weight of the initial litter placed in the litterbags and $\mathrm{m}_{1}$ the dry weight of litter at harvest. To measure carbon $(\mathrm{C})$ and nitrogen $(\mathrm{N})$ concentrations, dried $\left(60^{\circ} \mathrm{C}, 72 \mathrm{~h}\right)$ leaves and roots were milled to powder $(<1 \mathrm{~mm})$ and analysed using a CN elemental analyser (Vario EL III, Elementar, Hanau, Germany).

Microbial basal respiration (BR) and microbial biomass $\left(\mathrm{C}_{\mathrm{mic}}\right)$ were measured using a computer-controlled $\mathrm{O}_{2}$ micro-compensation apparatus (Scheu 1992). BR $\left(\mu \mathrm{O}_{2} \mathrm{~g}^{-1}\right.$ dry weight $\mathrm{h}^{-1}$ ) was determined as mean $\mathrm{O}_{2}$ consumption rates 10 to $20 \mathrm{~h}$ after attachment of the samples to the respirometer. $\mathrm{C}_{\text {mic }}$ was calculated from the maximum initial respiratory response (MIRR; $\mu 1 \mathrm{O}_{2} \mathrm{~g}^{-1} \mathrm{~h}^{-1}$ ) measured after glucose saturation following the SIR method of Anderson and Domsch (1978). MIRR was calculated as the average of the lowest three readings within the first $10 \mathrm{~h}$ and $\mathrm{C}_{\text {mic }}$ was calculated as $\mathrm{C}_{\text {mic }}=38 \times$ MIRR (mg g-1 dry weight) (Beck et al. 1997; Joergensen and Scheu 1999).

\section{Statistical analyses}

Analyses were performed using R version 3.6.0 (R Core Team 2019). Each data set was checked for normality and homoscedasticity using Shapiro-Wilk test and Bartlett's test (package "stats"). Data was log-transformed if necessary. Changes in $\mathrm{M}_{\text {loss }}, \mathrm{C}_{\text {mic }}, \mathrm{BR}$ and abundance of Oribatida and Collembola, as well as Oribatida richness were analyzed separately for leaf and root litter using linear mixed-effects models (package "nlme") with sampling date (6 and 12 months), mesh size ( $45 \mu \mathrm{m}, 1 \mathrm{~mm}$ and $4 \mathrm{~mm}$ ), altitude (1000, 2000 and $3000 \mathrm{~m}$ a.s.l.) and all possible interactions fitted as fixed factors, and block fitted as random factor. Differences between means were inspected using Tukey's honestly significant difference test (package "emmeans"). Means presented in text and figures are based on non-transformed data.

Oribatida species with more than three individuals across all samples were used for nonmetric multidimensional scaling (stress $=0.04, \mathrm{k}=6$; package "vegan"). Multivariate analysis of variance (MANOVA; package "stats") and linear discriminant analyses (LDA; 
package "MASS") were used to assess differences on Oribatida community composition among altitudes and mesh sizes in both leaf and root litter. Significant differences between group centroids were identified using Squared Mahalanobis Distances $\left(\mathrm{MD}^{2}\right)$.

Canonical correspondence analysis (CCA) performed in CANOCO (Ter Braak and Smilauer 2012) was used to explore the relationship between Oribatida community composition and litter characteristics $\left(\mathrm{M}_{\text {loss }}, \mathrm{C}\right.$-to- $\mathrm{N}$ ratio) as well as microbial indicators (BR, $\mathrm{C}_{\mathrm{mic}}$ ). Monte Carlo randomization tests using 999 simulations were used to determine the significance of the axes. Sampling date (6 and 12 months), mesh sizes ( $45 \mu \mathrm{m}, 1 \mathrm{~mm}$ and $4 \mathrm{~mm}$ ) and altitude (1000, 2000 and $3000 \mathrm{~m}$ a.s.l.) were coded as supplementary variables not affecting the ordination. Since the global test with all litter and microbial indicators was significant, we used forward selection to identify the most important variables structuring Oribatida communities. This was done to reduce the number of explanatory variables entering the analysis while keeping the variation explained caused by them at a maximum. The forward selection procedure was stopped if a variable reached a level of significance $>0.05$.

\section{Results}

\section{Decomposition of leaves and roots}

Generally, $\mathrm{M}_{\mathrm{loss}}$ significantly increased during the time of exposure reaching averages of $46.6 \% \pm 10.1 \%$ and $46.6 \% \pm 10.7 \%$ for leaf and root litter after 12 months, respectively. $\mathrm{M}_{\text {loss }}$ of leaf litter was not significantly affected by any interaction between the three factors studied, but at both sampling dates it was higher at 1000 and $2000 \mathrm{~m}$ compared to $3000 \mathrm{~m}$ (Figure 1, Table 1). By contrast, in root litter the interactions between altitude and date, as well as between altitude and mesh size significantly affected $M_{\text {loss. }}$. After 6 months root litter $\mathrm{M}_{\text {loss }}$ was at a maximum at $1000 \mathrm{~m}$ and similar in 2000 and $3000 \mathrm{~m}$, whereas after 12 months it decreased in a linear way with increasing altitude. Further, at $3000 \mathrm{~m}$ root litter $\mathrm{M}_{\text {loss }}$ in litterbags of $4 \mathrm{~mm}$ mesh size $(37.6 \% \pm 5.9 \%)$ was higher than in litterbags of 45 $\mu \mathrm{m}$ and $1 \mathrm{~mm}$ mesh size (averages of $29.7 \% \pm 8.7 \%$ and $26.2 \% \pm 9.5 \%$, respectively), 
whereas at 1000 and $2000 \mathrm{~m} \mathrm{M}_{\text {loss }}$ was not affected by mesh size (averages of $46.6 \% \pm$ $12.7 \%$ and $35.8 \% \pm 13.7)$.

\begin{tabular}{|c|c|c|c|c|c|c|c|c|}
\hline & \multicolumn{2}{|c|}{$\mathbf{M}_{\text {loss }}$} & \multicolumn{2}{|c|}{ C-to-N } & \multicolumn{2}{|c|}{$\mathrm{C}_{\text {mic }}$} & \multicolumn{2}{|c|}{ BR } \\
\hline & $F$-value & $p$-value & $F$-value & $p$-value & $F$-value & $p$-value & $F$-value & $p$-value \\
\hline \multicolumn{9}{|l|}{ Leaf litter } \\
\hline Time & 152.01 & $<0.001$ & 21.41 & $<0.001$ & 21.82 & $<0.001$ & 39.37 & $<0.001$ \\
\hline Mesh size & 0.069 & 0.527 & 1.05 & 0.362 & 20.21 & $<0.001$ & 6.98 & 0.003 \\
\hline Altitude & 24.33 & $<0.001$ & 233.30 & $<0.001$ & 16.74 & $<0.001$ & 12.82 & $<0.001$ \\
\hline Time $\times$ mesh size & 1.42 & 0.255 & 0.02 & 0.980 & 0.30 & 0.741 & 5.47 & 0.009 \\
\hline Time $\times$ altitude & 2.84 & 0.072 & 2.74 & 0.078 & 8.17 & 0.001 & 2.46 & 0.104 \\
\hline $\begin{array}{l}\text { Mesh size } \times \\
\text { altitude }\end{array}$ & 0.55 & 0.697 & 0.29 & 0.882 & 1.58 & 0.201 & 0.76 & 0.561 \\
\hline $\begin{array}{l}\text { Time } \times \text { mesh size } \\
\times \text { Altitude }\end{array}$ & 1.13 & 0.360 & 0.24 & 0.911 & 3.67 & 0.013 & 8.16 & $<0.001$ \\
\hline \multicolumn{9}{|l|}{ Root litter } \\
\hline Time & 110.09 & $<0.001$ & 0.06 & 0.806 & 167.86 & $<0.001$ & 226.11 & $<0.001$ \\
\hline Mesh size & 0.79 & 0.461 & 4.46 & 0.019 & 1.62 & 0.213 & 0.96 & 0.391 \\
\hline Altitude & 30.19 & $<0.001$ & 106.07 & $<0.001$ & 128.27 & $<0.001$ & 32.67 & $<0.001$ \\
\hline Time $\times$ mesh size & 0.21 & 0.808 & 0.97 & 0.388 & 0.90 & 0.416 & 2.17 & 0.129 \\
\hline Time $\times$ altitude & 8.01 & 0.001 & 0.99 & 0.382 & 18.33 & $<0.001$ & 1.14 & 0.332 \\
\hline $\begin{array}{l}\text { Mesh size } \times \\
\text { altitude }\end{array}$ & 3.26 & 0.023 & 1.61 & 0.193 & 6.81 & $<0.001$ & 6.19 & $<0.001$ \\
\hline $\begin{array}{l}\text { Time } \times \text { mesh size } \\
\times \text { Altitude }\end{array}$ & 1.67 & 0.179 & 2.42 & 0.067 & 5.47 & 0.001 & 1.16 & 0.343 \\
\hline
\end{tabular}

Table 1. $F$ - and $P$-values of linear mixed-effects models on the effect of time of exposure (6 and 12 months), mesh size ( $45 \mu \mathrm{m}, 1 \mathrm{~mm}, 4 \mathrm{~mm})$ and altitude (1,000, 2,000 and 3,000 m a.s.1.) on mass loss $\left(\mathrm{M}_{\text {loss }}\right)$, litter $\mathrm{C}$-to- $\mathrm{N}$ ratio, microbial biomass $\left(\mathrm{C}_{\mathrm{mic}}\right)$ and basal respiration $(\mathrm{BR})$ in leaf and root litter. Significant effects are given in bold, $\mathrm{p} \leq 0.05$. 


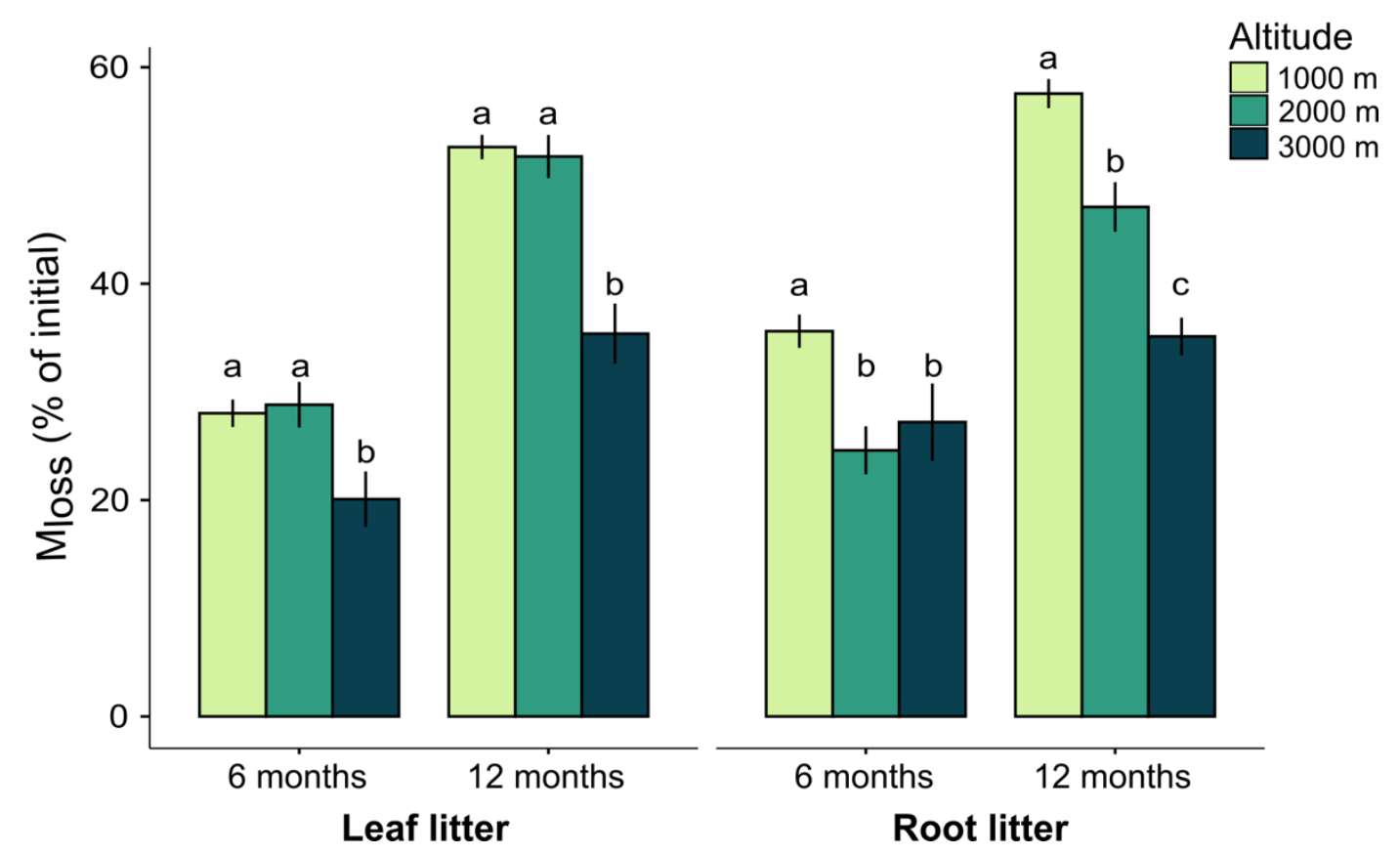

Figure 1. Effect of altitude on mass loss $\left(M_{\text {loss }}\right)$ after 6 and 12 months. Variations in $M_{\text {loss }}$ of leaf and root litter exposed in litterbags at three different altitudes $(1000 \mathrm{~m}, 2000 \mathrm{~m}, 3000 \mathrm{~m})$ for 6 and 12 months. Values are means \pm SE. For each litter type, bars marked with different letters within each time of exposure differ significantly (Tukey's HSD tests, $\mathrm{p}<0.05$ ).

The C-to-N ratio of both leaf and root litter significantly increased with altitude from 1000 $\mathrm{m}(23.7 \pm 2.9$ and $39.6 \pm 4.2$, respectively) to similar values at $2000 \mathrm{~m}(59.5 \pm 11.7$ and $65.1 \pm 9.0$, respectively) and $3000 \mathrm{~m}(63.7 \pm 7.0$ and $69.0 \pm 9.6$, respectively) (Table 1$)$. In leaf litter the C-to-N ratio decreased from $53.9 \pm 22.3$ after 6 months to $44.9 \pm 17.5$ after 12 months, whereas the C-to- $\mathrm{N}$ ratio in root litter did not change with the time (overall mean $57.4 \pm 14.9$ ). In leaf litter mesh size did not affect the C-to-N ratio, whereas the Cto-N ratio in root litter was lower in litterbags with $45 \mu \mathrm{m}$ mesh size $(53.7 \pm 13.1)$ compared to litterbags with 1 and $4 \mathrm{~mm}$ mesh size $(59.0 \pm 16.0$ and $59.5 \pm 15.3$, respectively).

\section{Microorganisms}

Generally, $\mathrm{C}_{\mathrm{mic}}$ and BR significantly increased from 6 to 12 months of exposure with averages after 12 months of $7.50 \pm 1.41 \mathrm{mg} \mathrm{C}_{\text {mic }} \mathrm{g}^{-1} \mathrm{dw}$ and $94.31 \pm 18.08 \mu \mathrm{l} \mathrm{O}_{2} \mathrm{~g}^{-1} \mathrm{dw} \mathrm{h}^{-1}$ for leaf litter, respectively, and $8.40 \pm 2.66 \mathrm{mg} \mathrm{C}_{\text {mic }} \mathrm{g}^{-1} \mathrm{dw}$ and $104.32 \pm 23.16 \mu \mathrm{O}_{2} \mathrm{~g}^{-1} \mathrm{dw}$ 
$\mathrm{h}^{-1}$ for root litter, respectively. $\mathrm{C}_{\text {mic }}$ and BR also varied with altitude in both litter types. In leaf litter, $\mathrm{C}_{\text {mic }}$ was higher at 1000 and $2000 \mathrm{~m}$ compared to $3000 \mathrm{~m}$, whereas $\mathrm{BR}$ significantly increased in the order $1000 \mathrm{~m}<3000 \mathrm{~m}<2000 \mathrm{~m}$. In root litter, $\mathrm{C}_{\text {mic }}$ was higher at $1000 \mathrm{~m}$ compared to 2000 and $3000 \mathrm{~m}$, whereas BR was higher at $1000 \mathrm{~m}$ compared to 2000 and $3000 \mathrm{~m}$ (for means of treatments see Appendix 2).

In leaf litter, variations in $\mathrm{C}_{\text {mic }}$ and $\mathrm{BR}$ with time depended on altitude; both generally were higher at $2000 \mathrm{~m}$ compared to 1000 and $3000 \mathrm{~m}$ after 6 months of exposure, while after 12 months $\mathrm{C}_{\text {mic }}$ was higher at 1000 and $2000 \mathrm{~m}$ compared to $3000 \mathrm{~m}$ and BR did not vary between altitudes (Figure 2, Table 1; for means pooled for mesh size see Appendix 3). However, the effect of altitude also varied with mesh size (significant three factor interaction). In leaf litter at $1000 \mathrm{~m} \mathrm{C}_{\text {mic }}$ and BR were lowest in bags with $1 \mathrm{~mm}$ mesh size after 6 months, whereas after 12 months $\mathrm{C}_{\text {mic }}$ was highest and $\mathrm{BR}$ was lowest in $4 \mathrm{~mm}$ mesh bags. At $2000 \mathrm{~m}, \mathrm{C}_{\mathrm{mic}}$ and $\mathrm{BR}$ were highest in $4 \mathrm{~mm}$ mesh bags, whereas after 12 months $\mathrm{C}_{\mathrm{mic}}$ did not vary with mesh size and $\mathrm{BR}$ was highest in $4 \mathrm{~mm}$ mesh bags. At $3000 \mathrm{~m}, \mathrm{C}_{\mathrm{mic}}$ and BR were not affected by mesh size after 6 months, whereas after 12 months $\mathrm{C}_{\mathrm{mic}}$ and BR were lowest in $1 \mathrm{~mm}$ mesh bags.

Similar to leaf litter, in root litter variations in $\mathrm{C}_{\text {mic }}$ with time depended on altitude and mesh size (Figure 2, Table 1; for means of treatments see Appendix 2). At $1000 \mathrm{~m}, \mathrm{C}_{\mathrm{mic}}$ was highest in $45 \mu \mathrm{m}$ mesh bags after both 6 and 12 months, whereas at $2000 \mathrm{~m}$ it was highest in $4 \mathrm{~mm}$ mesh bags and did not vary with mesh size after 12 months. At $3000 \mathrm{~m}$, $\mathrm{C}_{\text {mic }}$ was not affected by mesh size after 6 months, whereas after 12 months it was highest in 1 and $4 \mathrm{~mm}$ mesh bags. Also, variations in BR in root litter with altitude depended on mesh size, but the effect was restricted to 1000 and $2000 \mathrm{~m}$ where BR was highest in litterbags with $45 \mu \mathrm{m}$ and $4 \mathrm{~mm}$ mesh size (Table 1, Figure 2; for means of treatments see Appendix 2). 


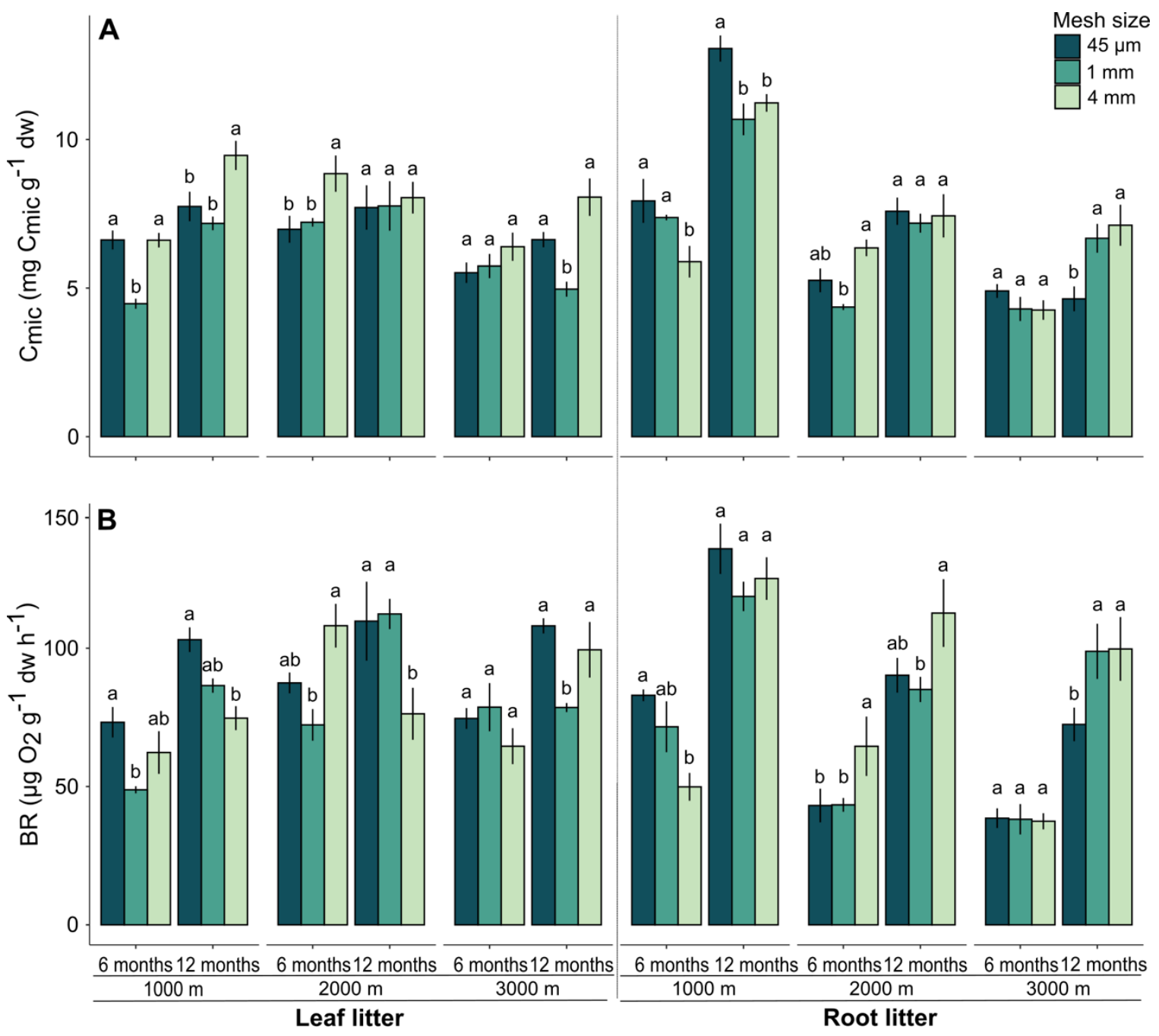

Figure 2. Effect of mesh size and altitude on Cmic and BR after 6 and 12 months of incubation. Variation in (A) microbial biomass $\left(\mathrm{C}_{\text {mic }}\right)$ and $(\mathbf{B})$ basal respiration (BR) in leaf litter (left panel) and root litter (right panel) at three altitudes (1000, $20003000 \mathrm{~m}$ a.s.l.) after 6 and 12 months of incubation. Values are means \pm SE. For each litter type, altitude and sampling date, bars marked with different letters differ significantly among mesh sizes (Tukey's HSD tests, $\mathrm{p}<0.05$ ).

\section{Abundance of Collembola and Oribatida}

Contrasting $\mathrm{C}_{\mathrm{mic}}$ and $\mathrm{BR}$, time of exposure as main effect neither affected the abundance of Collembola nor that of Oribatida (Table 2). Rather, the abundance of Collembola and Oribatida in both litter types varied strongly with altitude and mesh size. The most 
important factor affecting the abundance of Collembola in both litter types was altitude, whereas the most important factor affecting the abundance of Oribatida was mesh size.

\begin{tabular}{|c|c|c|c|c|c|c|}
\hline & \multirow{2}{*}{\multicolumn{2}{|c|}{$\begin{array}{l}\text { Collembola } \\
\text { Abundance }\end{array}$}} & \multicolumn{4}{|c|}{ Oribatida } \\
\hline & & & \multicolumn{2}{|c|}{ Abundance } & \multicolumn{2}{|c|}{ Richness } \\
\hline & $F$-value & $p$-value & $F$-value & $p$-value & $F$-value & $p$-value \\
\hline \multicolumn{7}{|l|}{ Leaf litter } \\
\hline Time & 0.09 & 0.756 & 0.07 & 0.783 & 0.04 & 0.841 \\
\hline Mesh size & 5.77 & 0.007 & 29.41 & $<0.001$ & 32.13 & $<0.001$ \\
\hline Altitude & 26.22 & $<0.001$ & 11.80 & $<0.001$ & 21.21 & $<0.001$ \\
\hline Time $\times$ mesh size & 0.15 & 0.857 & 2.64 & 0.085 & 4.63 & 0.016 \\
\hline Time $\times$ altitude & 3.25 & 0.051 & 0.07 & 0.933 & 0.48 & 0.61 \\
\hline $\begin{array}{l}\text { Mesh size } \times \\
\text { altitude }\end{array}$ & 0.34 & 0.849 & 0.519 & 0.722 & 0.79 & 0.541 \\
\hline $\begin{array}{l}\text { Time } \times \text { mesh size } \times \\
\text { Altitude }\end{array}$ & 2.14 & 0.097 & 2.41 & 0.068 & 2.82 & 0.039 \\
\hline \multicolumn{7}{|l|}{ Root litter } \\
\hline Time & 0.01 & 0.895 & 0.25 & 0.618 & 0.01 & 0.921 \\
\hline Mesh size & 2.61 & 0.088 & 33.47 & $<0.001$ & 37.86 & $<0.001$ \\
\hline Altitude & $\mathbf{5 3 . 0 7}$ & $<0.001$ & 64.88 & $<0.001$ & 70.23 & $<0.001$ \\
\hline Time $\times$ mesh size & 0.14 & 0.870 & 0.34 & 0.71 & 0.75 & 0.481 \\
\hline Time $\times$ altitude & 1.59 & 0.217 & 1.78 & 0.18 & 2.25 & 0.121 \\
\hline $\begin{array}{l}\text { Mesh size } \times \\
\text { altitude }\end{array}$ & 3.81 & 0.011 & 6.01 & $<0.001$ & 3.57 & 0.015 \\
\hline $\begin{array}{l}\text { Time } \times \text { mesh size } \times \\
\text { Altitude }\end{array}$ & 1.92 & 0.129 & 0.73 & 0.57 & 0.77 & 0.553 \\
\hline
\end{tabular}

Table 2. F- and P-values of linear mixed-effects models on the effect of time of exposure (6 and 12 months), mesh size (45 $\mu \mathrm{m}, 1 \mathrm{~mm}, 4 \mathrm{~mm}$ ) and altitude (1,000, 2,000 and 3,000 m a.s.1.) on the abundance of Collembola, and the abundance and richness of Oribatida in leaf and root litter. Significant effects are given in bold, $\mathrm{p} \leq 0.05$.

Overall, the abundance of Collembola in root litter ( $60 \pm 58$ ind. $10 \mathrm{~g}^{-1}$ litter $\left.\mathrm{dw}\right)$ exceeded that in leaf litter $\left(31 \pm 38\right.$ ind. $10 \mathrm{~g}^{-1}$ litter $\left.\mathrm{dw}\right)$. Generally, in both litter types the abundance decreased strongly with increasing altitude (Figure 3A, Table 2; for means of treatments see Appendix 4). However, in leaf litter the decrease varied with sampling date and was 
restricted to the second sampling where Collembola abundance was higher at $1000 \mathrm{~m}$ (41 \pm 26 ind. $10 \mathrm{~g}^{-1}$ litter $\left.\mathrm{dw}\right)$ compared to 2000 and $3000 \mathrm{~m}\left(18 \pm 19\right.$ and $13 \pm 11$ ind. $10 \mathrm{~g}^{-1}$ litter dw). Further, in leaf litter Collembola abundance was significantly higher in 1 and 4 $\mathrm{mm}$ mesh bags compared to $45 \mu \mathrm{m}$ mesh bags, however, the differences were not pronounced (averages of $32 \pm 27,33 \pm 43$ and $28 \pm 44$ ind. $10 \mathrm{~g}^{-1}$ litter dw, respectively). In root litter, the abundance of Collembola did not vary significantly with mesh size as main factor but the effect of mesh size depended on altitude; Collembola abundance did not vary with mesh size at 1000 and $2000 \mathrm{~m}$, but at $3000 \mathrm{~m}$ it was higher in 1 and $4 \mathrm{~mm}$ mesh bags than in $45 \mu \mathrm{m}$ mesh bags. Generally, high abundance of Collembola in $45 \mu \mathrm{m}$ mesh bags reflects that Collembola also effectively colonized leaf and root litterbags of this small mesh size.
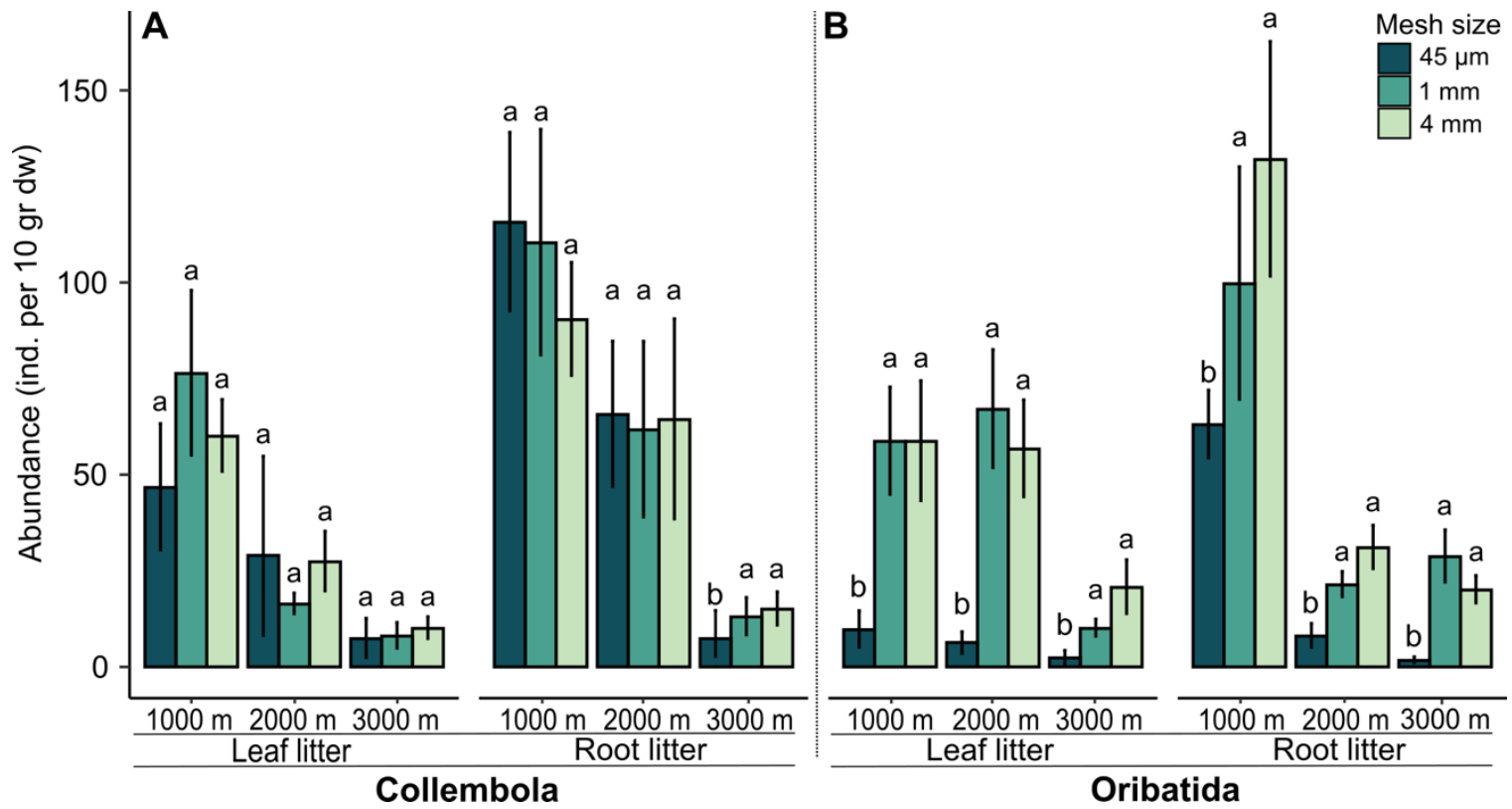

Figure 3. Effect of mesh size and altitude on Collembola and Oribatida abundance in leaf and root litter. Variations in (A) Collembola and (B) Oribatida abundance in leaf and root litter in litterbags of different mesh size $(45 \mu \mathrm{m}, 1 \mathrm{~mm}$ and $4 \mathrm{~mm})$ at three altitudes $(1000,2000$ and 3000 $\mathrm{m})$. Values are means \pm SE. Bars marked with different letters within each altitude differ significantly (Tukey's HSD tests, $\mathrm{p}<0.05$ ).

Generally, across altitude, sampling time and mesh size the abundance of Oribatida (37 \pm 45 ind. $10 \mathrm{~g}^{-1}$ litter $\mathrm{dw}$ ) was similar to that of Collembola ( $45 \pm 51$ ind. $10 \mathrm{~g}^{-1}$ litter $\left.\mathrm{dw}\right)$. 
However, in contrast to Collembola, the overall abundance of Oribatida in leaf and root litter was similar ( $32 \pm 35$ and $45 \pm 54$ ind. $10 \mathrm{~g}^{-1}$ litter $\mathrm{dw}$, respectively). Further, contrasting the pattern in Collembola, the abundance of Oribatida in leaf litter was similar at 1000 and $2000 \mathrm{~m}$ and significantly lower at $3000 \mathrm{~m}$, whereas in root litter the abundance at $1000 \mathrm{~m}$ strongly exceeded that at 2000 and $3000 \mathrm{~m}$ (Figure 3B, Table 2; for means of treatments see Appendix 4). Further, in contrast to Collembola, in both litter types the abundance of Oribatida was generally low in litterbags of $45 \mu \mathrm{m}$ mesh size and similar in litterbags of 1 and $4 \mathrm{~mm}$ mesh size. However, in root litter the effect varied with altitude with the abundance of Oribatida in litterbags of $45 \mu \mathrm{m}$ mesh size being considerably higher at $1000 \mathrm{~m}$ than at 2000 and $3000 \mathrm{~m}$.

\section{Species richness of Oribatida}

In both leaf and root litter the average Oribatida species richness per litterbag was significantly affected by mesh size and altitude (Table 2). In leaf litter the number of species significantly declined with altitude from $11 \pm 8$ to $5 \pm 1$ to $3 \pm 2$ species $10 \mathrm{~g}^{-1}$ at 1000 , 2000 and $3000 \mathrm{~m}$, respectively. By contrast, in root litter Oribatida species richness was highest at $1000 \mathrm{~m}\left(19 \pm 9\right.$ species $10 \mathrm{~g}^{-1}$ litter $)$ and similarly low at 2000 and $3000 \mathrm{~m}(6 \pm$ 3 and $5 \pm 4$ species $10 \mathrm{~g}^{-1}$ litter, respectively). In leaf litter, Oribatida species richness was generally higher in litterbags with 1 and $4 \mathrm{~mm}$ than in those with $45 \mu \mathrm{m}$ mesh size at all three altitudes, but at 1000 and $3000 \mathrm{~m}$ after 12 months it did not vary between litterbags of different mesh size (significant interaction between time, altitude and mesh size; for means of treatments see Appendix 4). Similar to leaf litter, in root litter Oribatida species richness was higher in litterbags with 1 and $4 \mathrm{~mm}$ compared to those with $45 \mu \mathrm{m}$ mesh size, but the variation depended on altitude with the effect being restricted to $1000 \mathrm{~m}$ where mesh size did not affect Oribatida richness.

\section{Community structure of Oribatida}

In total, 176 species of Oribatida were identified (see Appendix 5 for full list of species). MANOVA performed with NMDS axis scores indicated that altitude was the most 
important factor affecting Oribatida community composition in both leaf and root litter $\left(F_{2,24}=18.96, P<0.001\right.$ and $F_{2,24}=22.14, P<0.001$, respectively). Sampling date also affected Oribatida community composition in leaf litter $\left(\mathrm{F}_{1,24}=3.62, \mathrm{P}=0.014\right)$ but not in root litter. In in both litter types the effect of altitude varied with time $\left(\mathrm{F}_{2,24}=2.72, \mathrm{P}=\right.$ 0.008 for leaf litter and $\mathrm{F}_{2,24}=6.20, \mathrm{P}<0.001$ for root litter). Mesh size did not affect Oribatida community composition neither in leaf nor in root litter. LDA separated Oribatida communities of the three altitudes in both leaf (Wilks' lambda $=0.08$, approx. $F=44.89, p$ $<0.001$; Figure 4A) and root litter (Wilks' lambda $=0.11$, approx. $\mathrm{F}=47.59, \mathrm{p}<0.001$; Figure 4B). In both litter types Oribatida communities at $1000 \mathrm{~m}$ were separated from those at 2000 and at $3000 \mathrm{~m}$ along the first axis, and Oribatida communities at $2000 \mathrm{~m}$ and 3000 $\mathrm{m}$ along the second axis (for Mahalanobis distances see Appendix 6).
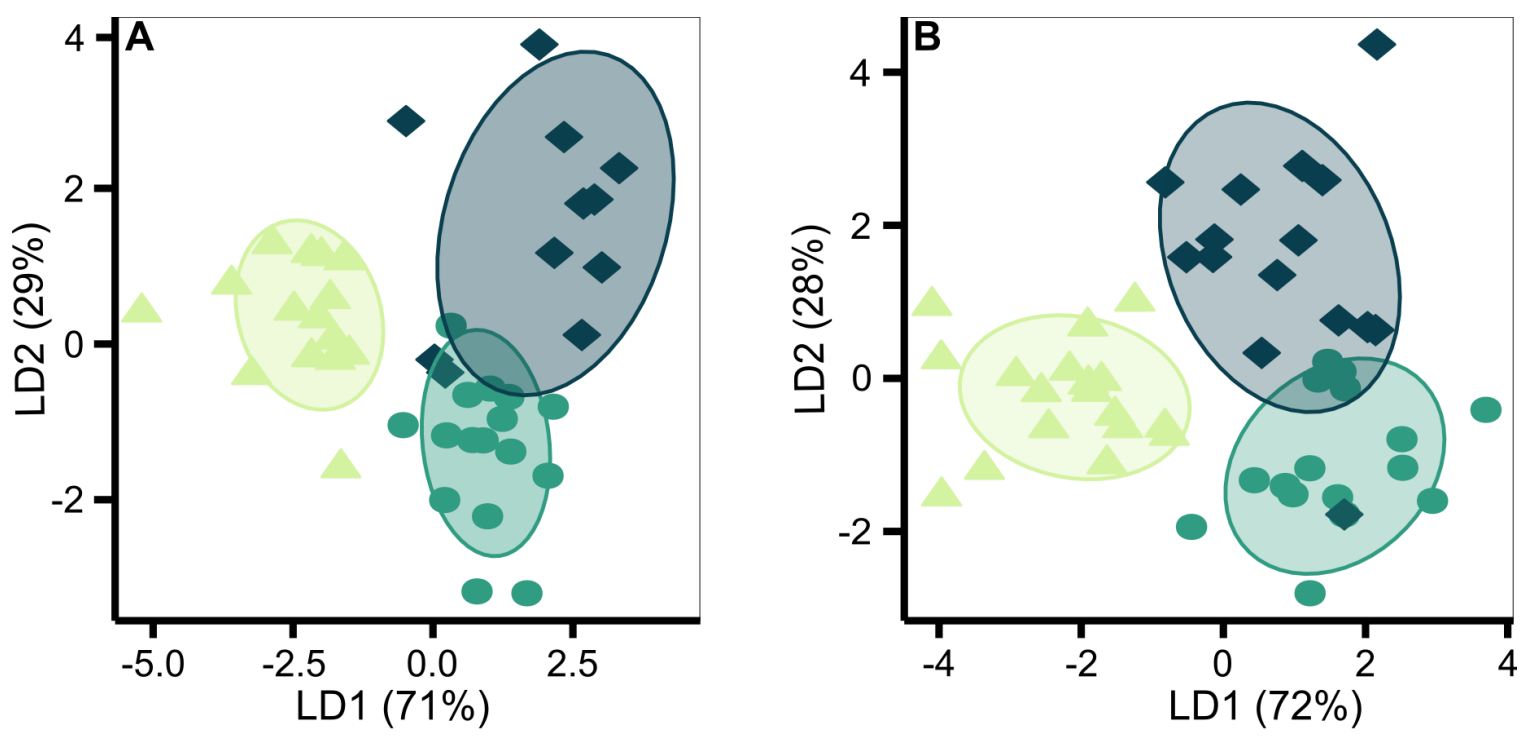

$1000 \mathrm{~m}-2000 \mathrm{~m} \otimes 3000 \mathrm{~m}$

Figure 4. Linear discriminant function analyses (LDA) of Oribatida community composition in litterbags with (A) leaf litter and (B) root litter exposed at three altitudes (1000, 2000 and $3000 \mathrm{~m})$ (pooled for 6 and 12 months of exposure). Ellipses represent $75 \%$ confidence ranges.

CCA of Oribatida species in leaf litter with $\mathrm{C}$-to- $\mathrm{N}$ ratio, $\mathrm{M}_{\text {loss, }}, \mathrm{BR}$ and $\mathrm{C}_{\text {mic }}$ included as environmental variables explained $12.7 \%$ of the variation of Oribatida community composition (Figure 5A); C-to-N ratio accounted for 4.4\% (pseudo $\mathrm{F}=1.9, \mathrm{P}=0.002$ ), 
$\mathrm{M}_{\text {loss }}$ for $4.3 \%$ (pseudo $\mathrm{F}=1.8, \mathrm{P}=0.002$ ) and $\mathrm{BR}$ for $3.9 \%$ (pseudo $\mathrm{F}=1.6, \mathrm{P}=0.007$ ). Similar to LDA, the $1000 \mathrm{~m}$ site was separated from the 2000 and $3000 \mathrm{~m}$ sites along the first axis, and the second axis separated the 2000 and $3000 \mathrm{~m}$ sites as well as the sampling dates. The community composition of Oribatida at 2000 and $3000 \mathrm{~m}$ correlated positively with increasing $\mathrm{C}$-to- $\mathrm{N}$ ratio and $\mathrm{BR} ; \mathrm{M}_{\text {loss }}$ correlated positively with the first sampling date and was associated with lower species abundance.

CCA of Oribatida species in root litter with $\mathrm{C}$-to-N ratio, $\mathrm{BR}, \mathrm{M}_{\text {loss }}$ and $\mathrm{C}_{\text {mic }}$ included as environmental variables explained $10.2 \%$ of the variation of Oribatida community composition (Figure 5B); C-to-N ratio accounted for $7.0 \%$ of the variation (pseudo $\mathrm{F}=3.7$, $\mathrm{P}<0.001$ ) and $\mathrm{BR}$ for $3.2 \%$ (pseudo $\mathrm{F}=1.6, \mathrm{P}=0.004)$. As in leaf litter, the $1000 \mathrm{~m}$ site was separated from the 2000 and $3000 \mathrm{~m}$ sites along the first axis, and the second axis separated the 2000 and $3000 \mathrm{~m}$ sites as well as the sampling dates. As in leaf litter, Oribatida species at 2000 and $3000 \mathrm{~m}$ correlated positively with increasing C-to-N ratio, but BR correlated positively with the sampling date after 12 months. In both the CCA of leaf and root litter, the centroids of mesh size were close to the center of the ordination reflecting that Oribatida communities in litterbags of different mesh size were similar.

Rostrozetes ovulum ovulum was the only species occurring in leaf and root litter across the three altitudes (Figure 5). From the species occurring in both litter types Cosmozetes reticulatus, Neoamerioppia longiclava, Rostrozetes carinatus and Hemileius hemileiformis were most abundant, with the Cosmozetes reticulatus and Hemileius hemileiformis occurring predominately at $1000 \mathrm{~m}$ and $3000 \mathrm{~m}$, respectively. Neoamerioppia longiclava and Rostrozetes carinatus were especially abundant in leaf litter at $2000 \mathrm{~m}$ (in total $>100$ and $>40$ individuals sampled, respectively). Most other species were rare and only occurred at certain altitudes; for the abundance of species at each of the study sites see Appendix 5.

Of the species present only in leaf litter, Neoamerioppia rotunda, Microtegeus borhidii, Sellnickochthonius elsosneadensis, Epieremulus sp.1 and Neoamerioppia longicoma were most abundant (in total 24, 12, 11, 10 and 8 individuals sampled, respectively) (Figure 5A). Sellnickochthonius elsosneadensis only occurred at $1000 \mathrm{~m}$ and Neoamerioppia rotunda and Epieremulus sp.1 only occurred at $2000 \mathrm{~m}$. Microtegeus borhidii occurred at 1000 and $3000 \mathrm{~m}$, whereas Neoamerioppia longicoma only occurred at 2000 and $3000 \mathrm{~m}$, but both 
were especially abundant at $3000 \mathrm{~m}$. Rostrozetes sp.6 and Lanceoppia sp.1 were associated with the second sampling date and were only present at $2000 \mathrm{~m}$.
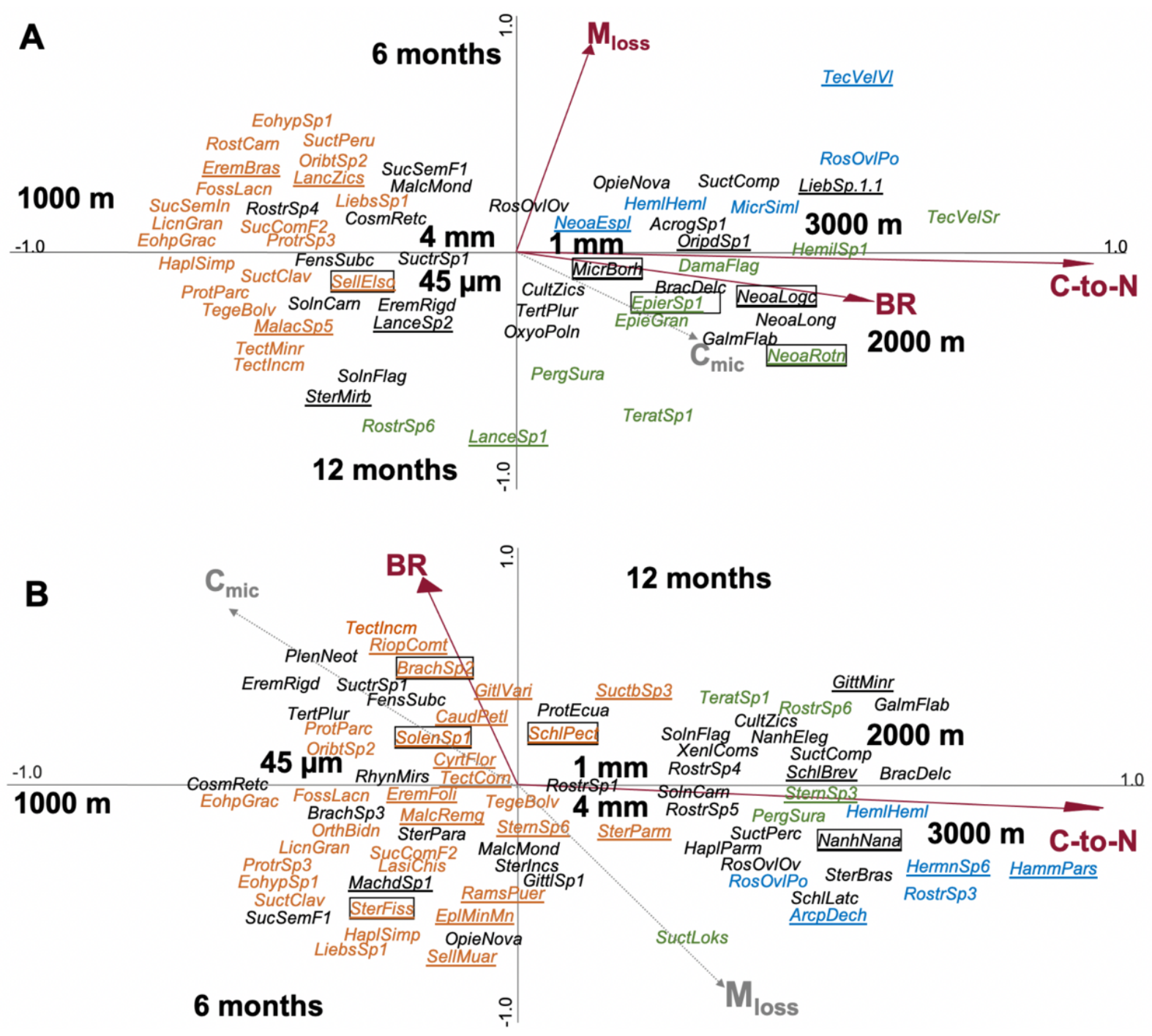

Figure 5. Canonical correspondence analysis (CCA) of Oribatida species in litterbags with (A) leaf and (B) root litter and their relationship with environmental variables (forward selection). Arrows in red represent significant environmental variables. Species present only at one of the three altitudes are marked in color (orange $=1000 \mathrm{~m}$, green $=2000 \mathrm{~m}$, blue $=$ $3000 \mathrm{~m}$ ); others are given in black. Species present in only one litter type are underlined and of them the most abundant species ( $>10$ individual across the samples) are framed; for full species names see Appendix 5. 
In root litter, Solenozetes sp.1, Brachioppiella sp.2, Schalleria pectinata, Sternoppia fissurata and Nanhermannia nana form.1 were most abundant (in total 52, 46, 22, 14 and 13 individuals sampled, respectively) with the first two being especially abundant at 1000 m (Figure 5B). Nanhermannia nana form.1 was only present at 2000 and $3000 \mathrm{~m}$.

\section{Discussion}

\section{Variations of leaf and root litter decomposition with altitude}

In contrast to our first hypothesis, $\mathrm{M}_{\text {loss }}$ of both leaf and root litter showed different patterns of decomposition along the altitudinal gradient. In leaf litter, $\mathrm{M}_{\text {loss }}$ did not follow the expected linear decrease with altitude, rather, decomposition rates at 1000 and $2000 \mathrm{~m}$ were similar after the 12 months of exposure. This contrasts previous studies at our study sites (Illig et al. 2008; Marian et al. 2017, 2019) and indicates that leaf litter decomposition cannot be explained only by the linear decrease of temperature along the altitudinal gradient studied. Potentially, the decline in leaf litter decomposition with temperature was compensated by higher precipitation at $2000 \mathrm{~m}$ compared to $1000 \mathrm{~m}$ (see Methods). High rainfall facilitates decomposition especially at early stages by increasing leaching of soluble compounds (Cusack et al. 2009). However, although climate is considered the primary driver of litter decomposition at large scales (Coûteaux et al. 1995; Aerts 1997), the role of climatic factors might be overridden by the variability of litter traits at local scales (Scowcroft et al. 2000; Richardson et al. 2005; Fujii et al. 2017). In our study, litter characteristics such as $\mathrm{C}$-to- $\mathrm{N}$ ratio differed strongly between the leaf litter materials exposed at the three altitudes. However, as indicated by the C-to-N ratio, leaf litter materials from the $1000 \mathrm{~m}$ site were of considerably higher quality than those from the $2000 \mathrm{~m}$ site (as well as the $3000 \mathrm{~m}$ site), suggesting that the high decomposition rates of leaf litter at $2000 \mathrm{~m}$ also cannot be explained by litter quality. Potentially, leaf litter $\mathrm{M}_{\text {loss }}$ was modified by physicochemical interactions among the three leaf litter species placed in the litterbags and biotic factors such as microbial community composition. The fact that $\mathrm{C}_{\text {mic }}$ and $\mathrm{BR}$ were higher in leaf litter at $2000 \mathrm{~m}$ than at $1000 \mathrm{~m}$ after 6 months of exposure supports this conclusion and suggests that the leaf litter mixtures favoured the activity and abundance of 
microbial communities early after exposure. The generally high values of $\mathrm{C}_{\text {mic }}$ and $\mathrm{BR}$ in leaf litter at 2000 and $3000 \mathrm{~m}$, despite the very high litter C-to-N ratio, also suggests that microbial communities at these sites are well adapted to decompose litter of low quality (Gholz et al. 2000; Strickland et al. 2009; Milcu and Manning 2011; Marian et al. 2017).

In contrast to leaf litter, root litter showed the expected linear decrease in litter decomposition with increasing altitude after 12 months. Less favorable abiotic conditions, such as those at higher altitude, might affect root litter decomposition by reducing the quality of the litter material and thereby nutrient availability as reported for tropical rainforests (Vitousek et al. 1994; Tanner et al. 1998; Kitayama et al. 2004). This is supported by the high $\mathrm{C}$-to- $\mathrm{N}$ ratios and low $\mathrm{C}_{\text {mic }}$ and $\mathrm{BR}$, as well as abundance of decomposer microarthropods at 2000 and $3000 \mathrm{~m}$ (compared to $1000 \mathrm{~m}$ ). This contrasting results between leaf and root litter decomposition rates suggest that in the studied tropical montane rainforest ecosystems, differences in the availability of nutrients and associated nutrient limitations among the altitudinal sites appear to be more important factors for the decomposition of root litter than for leaf litter. Moreover, leaf litter might be more susceptible than roots to effects of climatic variations as leaf litter is located on top of the soil and thereby exposed to more variable microclimatic conditions than root litter in soil (Ostertag and Hobbie 1999; Silver and Miya 2001). However, as root litter generally decomposed slower than leaf litter at 2000 and $3000 \mathrm{~m}$, more buffered conditions in soil do not implicate an override of the primacy of nutrient limitations as driving factor of litter decomposition. Nonetheless, at $1000 \mathrm{~m}$ the more buffered climatic condition together with the close proximity of the mineral soil layer at $1000 \mathrm{~m}$ might have favoured the faster decomposition rates of roots than leaf litter.

\section{Faunal contribution to leaf and root litter decomposition along the altitudinal gradient}

The abundance of both Collembola and Oribatida were higher in 1 and $4 \mathrm{~mm}$ mesh bags irrespective of the plant litter type indicating that, as intended, $45 \mu \mathrm{m}$ mesh size restricted the access of the litterbags by mesofauna. Thus, the different mesh sizes are a useful tool to evaluate the effects of microarthropods on decomposition processes. However, 
restricting the access of the litterbags by $45 \mu \mathrm{m}$ mesh size was more effective in Oribatida than in Collembola indicating that the mesh size approach is limited for evaluating the role of mesofauna for decomposition processes and suggesting that it likely underestimates their effects on litter decomposition as discussed earlier (Bradford et al. 2002; Kampichler and Bruckner 2009). Further, contrasting our second hypothesis, access of microarthropods to litterbags containing leaf litter did not result in different decomposition rates at any of the three altitudes, however, arthropod access to root litter increased root litter mass loss at $3000 \mathrm{~m}$ (4 mm mesh bags). Despite the widely assumed beneficial effects of soil microarthropods on litter decomposition, experimental evidence supporting this assumption is mixed; some studies indeed found positive effects on litter mass loss (Bradford et al. 2002; Carrillo et al. 2011; Bokhorst and Wardle 2013), while others suggest their contribution to be minor or lacking entirely (Schinner 1982; Joo et al. 2003; Kampichler and Bruckner 2009; Marian et al. 2019). Overall, our results support the latter and previous findings at our study sites also indicating that the decomposition of leaf litter predominantly is due to microorganisms, with the contribution of microarthropods being minor, in particular at early stages of litter decomposition (Illig et al. 2008; Marian et al. 2017, 2019). Both decomposer groups, Oribatida and Collembola, might play a more important role at more advanced stages of decomposition when the litter has been colonized by microorganisms thereby making it more palatable for arthropod consumers (Bardgett 2005; Coulis et al. 2009; Das and Joy 2009). However, the fact that the abundance of both decomposer microarthropods did not vary significantly with sampling date indicates that the nutritional value of the litter material for decomposer microarthropods changed little during the 12 months of exposure.

Notably, contrasting $\mathrm{M}_{\text {loss }}, \mathrm{C}_{\mathrm{mic}}$ and $\mathrm{BR}$ varied with mesh size in both leaf and root litter with the effect in root but not in leaf litter varying with altitude. Generally, $\mathrm{C}_{\text {mic }}$ was higher in 1 and $4 \mathrm{~mm}$ mesh bags, while BR was higher in $45 \mu \mathrm{m}$ mesh bags. Overall, this contrasts our expectation that decomposer microarthropods are grazing on microorganisms thereby reducing their biomass. However, as suggested earlier this view might be oversimplistic as grazing on microorganisms may also result in increased mobilization of nutrients, thereby facilitating microbial growth (Seastedt 1984; Hättenschwiler et al. 2005). Further, grazing may result in changes in microbial community composition resulting in more effective use 
of resources by microorganisms and this may explain the reduced BR in litterbags with coarse mesh size. Indeed, it has been stressed earlier that the structure of microbial communities is an important determinant of litter decomposition rates in particular in forest ecosystems (Strickland et al. 2009).

Increased $\mathrm{M}_{\text {loss }}$ of root litter at $3000 \mathrm{~m}$ in $4 \mathrm{~mm}$ compared to $1 \mathrm{~mm}$ and $45 \mu \mathrm{m}$ mesh bags suggests that under unfavourable environmental conditions the decomposition of lowquality litter is stimulated by soil arthropods. A number of processes may have accelerated litter decomposition including stimulation of microbial growth via nutrient mobilization, litter fragmentation and dispersal of microbial propagules (Verhoef and Brussaard 1990; Ruess and Lussenhop 2005; Scheu et al. 2005). The fact that at $3000 \mathrm{~m} \mathrm{C} \mathrm{Cmic}_{\text {and }}$ aR in roots increased in 1 and $4 \mathrm{~mm}$ mesh bags supports this conclusion and suggests that the contribution of arthropods to decomposition of recalcitrant substrates is more pronounced than in readily decomposable materials (Joo et al. 2006; Milcu and Manning 2011; Gergócs and Hufnagel 2016). Additionally, at our study sites, the role of root exudates and mycorrhizal fungi are increasingly recognized as drivers of litter decomposition, mineralization processes and determinants of soil food webs (Marian et al. 2019; SánchezGalindo et al. 2019). Therefore, at $3000 \mathrm{~m}$, where the concentration of root biomass is at a maximum (Röderstein et al. 2005; Soethe et al. 2007), soil arthropods may benefit more from root-derived resources than at 1000 and $2000 \mathrm{~m}$ either by grazing on microorganisms or directly by feeding on roots.

\section{Oribatida diversity and community structure in leaf and root litter}

Similar to Oribatida abundance, the higher number of Oribatida species in litterbags of 1 and $4 \mathrm{~mm}$ mesh size in both litter types might be attributed to restricted access of microarthropods to the $45 \mu \mathrm{m}$ mesh litterbags. However, Oribatida species richness mostly varied with altitude in both leaf and root litter. The significant decrease in Oribatida species richness with increasing altitude in leaf litter supports results of previous studies at our study sites in that species richness of Oribatida in leaf litter is driven predominantly by factors linked to altitude (Illig et al. 2008; Marian et al. 2018). By contrast, in root litter the high number of Oribatida species at $1000 \mathrm{~m}$ and the similarly low numbers at 2000 and 
$3000 \mathrm{~m}$ suggests that apart from abiotic conditions changing with altitude other factors modify Oribatid species richness. The fact that $\mathrm{C}$-to-N ratios of root litter were similar at 2000 and $3000 \mathrm{~m}$ support this conclusion and suggests that root litter quality may function as regulator of Oribatida richness; potentially, high amounts of slightly decomposed low quality root litter material detrimentally affect Oribatida richness at 2000 and $3000 \mathrm{~m}$ (Röderstein et al. 2005; Maraun et al. 2013). Contrasting our third hypothesis, higher Oribatida species richness at $1000 \mathrm{~m}$ in roots compared to leaves might be related to the placement of the litterbags with more stable environmental conditions in roots favouring Oribatida richness (Fujii and Takeda 2010). Moreover, the close vicinity of the mineral soil layer to root litter at $1000 \mathrm{~m}$ might have favoured nutrient availability and decomposition of roots, and thereby improved food resources of Oribatida (Marian et al. 2019). Indeed, Illig et al. (2010) also concluded that Oribatida species richness at the studied montane rainforests is related to litter quality as important driving factor.

Contrasting Oribatida abundance and richness, Oribatida community structure did not differ between litterbags of different mesh size. Rather, Oribatida community assemblages varied mostly with altitude in both leaf and root litter. Most of the 176 species identified were associated with the $1000 \mathrm{~m}$ site, only few species were only present at 2000 and 3000 $\mathrm{m}$, presumably reflecting less favorable climatic conditions and poor resource quality at the high altitude sites (Marian et al. 2018). Interestingly, in leaf litter certain Oribatida species including Sternoppia mirbilis, Lanceoppia sp.1 and Rostrozetes sp.6 preferentially colonized litter at later stages of decomposition (12 months) with the latter two species exclusively recorded at $2000 \mathrm{~m}$. This contrast our fourth hypothesis indicating that certain Oribatida species rely on food resources associated with litter at later stages of decomposition particularly at higher elevations, suggesting that Oribatida species diversity at least in part is due to resource partitioning (Marian et al. 2018). This is supported by our finding that litter C-to-N ratio functions as important factor structuring Oribatida communities in both leaf and root litter. Contrasting leaf litter, changes in root litter with time did not affect Oribatida community structure, despite changes in $\mathrm{C}_{\text {mic }}$ and $\mathrm{BR}$ with time were more pronounced in root than in leaf litter. This suggests that Oribatida community structure is not closely linked with gross characteristics of microbial communities such as $\mathrm{C}_{\text {mic }}$ and $\mathrm{BR}$, which is also supported by the fact that both $\mathrm{C}_{\text {mic }}$ and 
BR varied strongly with time of exposure of the litter, whereas Oribatida community characteristics did not or only little (and the same was true for Collembola abundance). Overall, this indicates that the community structure of Oribatida is driven mainly by food quality, i.e. litter C-to-N ratio, as well as microbial community composition, rather than the amount of microorganisms as food resource (Fujii and Takeda 2017; Marian et al. 2018).

\section{Conclusion}

The results of our study suggest that the decomposition of both leaf and root litter in montane rainforests is mainly due to microorganisms, whereas the effect of microarthropods is minor across a wide altitudinal gradient. However, at high altitude soil microarthropods may accelerate the decomposition of low-quality litter such as root litter. Generally, abundance of both Collembola and Oribatida, and community composition of Oribatida varied not or little with time of exposure of leaf and root litter, contrasting the patterns of microbial biomass and highlighting that the abundance of microorganisms as food is of minor importance as structuring force of decomposer microarthropod communities. Rather, the results point to the dominance of litter quality, i.e. litter C-to-N ratio, as dominant force structuring Oribatida communities. Overall, our findings highlight that the role of climatic factors for decomposition of leaf and root litter might be overridden at the local scale by litter traits suggesting that differences in litter quality and the nutritional requirements of decomposer communities are important drivers of litter decomposition and nutrient cycling in tropical montane rainforest ecosystem.

\section{Acknowledgements}

We thank the Deutsche Forschungsgemeinschaft (DFG; FOR816) for financial support. Further, we thank the Ministerio de Ambiente del Ecuador and the Universidad Técnico Particular de Loja (UTPL) for the research permits and the center Naturaleza y Cultura Internacional (NCI) to allow us to work in the San Francisco reserve. We thank student helpers for the collaboration during the field work, Kristina Barnes and Stephan Töppich for their work in the laboratory and Tamara Hartke and Jingzhong Lu for helpful comments. 


\section{References}

Aerts R (1997) Climate, leaf litter chemistry and leaf litter decomposition in terrestrial ecosystems: A triangular relationship. Oikos 79:439

Anderson JPE, Domsch KH (1978) A physiological method for the quantitative measurement of microbial biomass in soils. Soil Biol Biochem 10:215-221

Balogh J, Balogh P (2002) Identification keys to the oribatid mites of the extra-holartic regions I. Well-Press Publishing Limited, Hungary

Balogh J, Balogh P (1990) Oribatid mites of the neotropical region II. Elsevier Science Publishers, Budapest

Bardgett RD (2005) The Biology of soils: A community and ecosystem approach. Oxford University Press

Beck E, Ritcher M (2008) Ecological aspects of a biodiversity hotspot in the Andes of southern Ecuador. Biodivers Ecol Ser 2:195-217

Beck T, Joergensen RG, Kandeler E, et al (1997) An inter-laboratory comparison of ten different ways of measuring soil microbial biomass C. Soil Biol Biochem 29:1023-1032

Bendix J, Homeier J, Cueva Ortiz E, et al (2006) Seasonality of weather and tree phenology in a tropical evergreen mountain rain forest. Int J Biometeorol 50:370-384

Berg B, McClaugherty C (2008) Plant litter, Second ed. Springer-Verlag Berlin Heidelberg

Bokhorst S, Wardle DA (2013) Microclimate within litter bags of different mesh size: Implications for the "arthropod effect" on litter decomposition. Soil Biol Biochem 58:147-152

Bradford MA, Tordoff GM, Eggers T, et al (2002) Microbiota, fauna, and mesh size interactions in litter decomposition. Oikos 99:317-323

Carrillo Y, Ball BA, Bradford MA, et al (2011) Soil fauna alter the effects of litter composition on nitrogen cycling in a mineral soil. Soil Biol Biochem 43:1440-1449

Coulis M, Hättenschwiler S, Rapior S, Coq S (2009) The fate of condensed tannins during litter consumption by soil animals. Soil Biol Biochem 41:2573-2578

Coûteaux MM, Bottner P, Berg B (1995) Litter decomposition, climate and litter quality. Tree 10:63-66 
Cusack DF, Chou WW, Yang WH, et al (2009) Controls on long-term root and leaf litter decomposition in neotropical forests. Glob Chang Biol 15:1339-1355

Das S, Joy VC (2009) Chemical quality impacts of tropical forest tree leaf litters on the growth and fecundity of soil Collembola. Eur J Soil Biol 45:448-454

Freschet GT, Aerts R, Cornelissen JHC (2012) A plant economics spectrum of litter decomposability. Funct Ecol 26:56-65

Freschet GT, Cornwell WK, Wardle DA, et al (2013) Linking litter decomposition of above- and below-ground organs to plant-soil feedbacks worldwide. J Ecol 101:943-952

Fujii S, Cornelissen JHC, Berg MP, Mori AS (2017) Tree leaf and root traits mediate soil faunal contribution to litter decomposition across an elevational gradient. Funct Ecol 32:840-852

Fujii S, Takeda H (2017) Succession of soil microarthropod communities during the aboveground and belowground litter decomposition processes. Soil Biol Biochem 110:95-102

Fujii S, Takeda H (2010) Dominant effects of litter substrate quality on the difference between leaf and root decomposition process above- and belowground. Soil Biol Biochem 42:22242230

García-Palacios P, Prieto I, Ourcival JM, Hättenschwiler S (2016) Disentangling the litter quality and soil microbial contribution to leaf and fine root litter decomposition desponses to reduced rainfall. Ecosystems 19:490-503

Gergócs V, Hufnagel L (2016) The effect of microarthropods on litter decomposition depends on litter quality. Eur J Soil Biol 75:24-30

Gholz HL, Wedin DA, Smitherman SM, et al (2000) Long-term dynamics of pine and hardwood litter in contrasting environments: Toward a global model of decomposition. Glob Chang Biol 6:751-765

Graefe S, Hertel D, Leuschner C (2008) Fine root dynamics along a $2000 \mathrm{~m}$ elevation transect in South Ecuadorian mountain rainforests. Plant Soil 313:155-166

Hättenschwiler S, Tiunov A V., Scheu S (2005) Biodiversity and litter decomposition in terrestrial ecosystems. Annu Rev Ecol Evol Syst 36:191-218

Hobbie SE, Oleksyn J, Eissenstat DM, Reich PB (2010) Fine root decomposition rates do not mirror those of leaf litter among temperate tree species. Oecologia 162:505-513 
Homeier J, Breckle S, Günter S, et al (2010) Tree diversity, forest structure and productivity along altitudinal and topographical gradients in a species-rich Ecuadorian montane rain forest. Biotropica 42:140-148

Homeier J, Werner FA, Gradstein SR, et al (2008) Potential vegetation and floristic composition of Andean forests in south Ecuador, with a focus on the RBSF. In: Beck E, Bendix J, Kottke I, et al. (eds) Gradients in a Tropical Mountain Ecosystem of Ecuador. Springer, Berlin, Heidelberg, pp 87-100

Illig J, Norton RA, Scheu S, Maraun M (2010) Density and community structure of soil- and bark-dwelling microarthropods along an altitudinal gradient in a tropical montane rainforest. Exp Appl Acarol 52:49-62

Illig J, Schatz H, Scheu S, Maraun M (2008) Decomposition and colonization by microarthropods of two litter types in a tropical montane rain forest in southern Ecuador. $J$ Trop Ecol 24:157-167

Jo I, Fridley JD, Frank DA (2016) More of the same? In situ leaf and root decomposition rates do not vary between 80 native and nonnative deciduous forest species. New Phytol 209:115-122

Joergensen RG, Scheu S (1999) Response of soil microorganisms to the addition of carbon, nitrogen and phosphorus in a forest Rendzina. Soil Biol Biochem 31:859-866

Joo SJ, Yim MH, Nakane K (2006) Contribution of microarthropods to the decomposition of needle litter in a Japanese cedar (Cryptomeria japonica D. Don) plantation. For Ecol Manage 234:192-198

Joo SJ, Yim MH, Nakane K (2003) Leaf litter decomposition in relation to dynamics of soil mesofaunain litter boxes with different mesh sizes in a Quercus serrata forest. Soc Appl For Sci 12:109-116

Kampichler C, Bruckner A (2009) The role of microarthropods in terrestrial decomposition: A meta-analysis of 40 years of litterbag studies. Biol Rev 84:375-389

Kempson D, Lloyd M, Ghelardi R (1963) A new extractor for woodland litter. Pedobiologia 3:121

Leuschner C, Moser G, Bertsch C, et al (2007) Large altitudinal increase in tree root/shoot ratio in tropical mountain forests of Ecuador. Basic Appl Ecol 8:219-230 
Macfadyen A (1961) Improved funnel-type extractors for soil arthropods. J Anim Ecol 30:171184

Maraun M, Fronczek S, Marian F, et al (2013) More sex at higher altitudes: Changes in the frequency of parthenogenesis in oribatid mites in tropical montane rain forests. Pedobiologia 56:185-190

Maraun M, Illig J, Sandmann D, et al (2008) Soil Fauna. In: Beck E, Bendix J, Kottke I, et al. (eds) Gradients in a tropical mountain ecosystem of Ecuador. Springer, Berlin, Heidelberg, pp 181-192

Marian F, Brown L, Sandmann D, et al (2019) Roots, mycorrhizal fungi and altitude as determinants of litter decomposition and soil animal communities in tropical montane rainforests. Plant Soil 438:1-18

Marian F, Sandmann D, Krashevska V, et al (2018) Altitude and decomposition stage rather than litter origin structure soil microarthropod communities in tropical montane rainforests. Soil Biol Biochem 125:263-274

Marian F, Sandmann D, Krashevska V, et al (2017) Leaf and root litter decomposition is discontinued at high altitude tropical montane rainforests contributing to carbon sequestration. Ecol Evol 7:6432-6443

Milcu A, Manning P (2011) All size classes of soil fauna and litter quality control the acceleration of litter decay in its home environment. Oikos 120:1366-1370

Moser G, Hertel D, Leuschner C (2007) Altitudinal change in LAI and stand leaf biomass in tropical montane forests: A transect study in ecuador and a pan-tropical meta-analysis. Ecosystems 10:924-935

Myers N, Mittermeier R, Mittermeier C, et al (2000) Biodiversity hotspots for conservation priorities. Nature 403:853-858

Norby RJ, Ledford J, Reilly CD, et al (2004) Fine-root production dominates response of a deciduous forest to atmospheric $\mathrm{CO}_{2}$ enrichment. Proc Natl Acad Sci U S A 101:9689-9693

Ostertag R, Hobbie SE (1999) Early stages of root and leaf decomposition in Hawaiian forests: Effects of nutrient availability. Oecologia 121:564-573

Potapov A, Sandmann D, Scheu S (2019) Ecotaxonomy database traits and species 
R Core Team (2019) R: A language and environment for statistical computing. https://www.rproject.org/

Richardson BA, Richardson MJ, Soto-Adames FN (2005) Separating the effects of forest type and elevation on the diversity of litter invertebrate communities in a humid tropical forest in Puerto Rico. J Anim Ecol 74:926-936

Röderstein M, Hertel D, Leuschner C (2005) Above- and below-ground litter production in three tropical montane forests in southern Ecuador. J Trop Ecol 21:483-492

Ruess L, Lussenhop J (2005) Trophic interactions of fungi and animals. In: Dighton J, Oudemans $\mathrm{P}$, White J (eds) The fungal community: its organization and role in the ecosystem. CRC, Boca Raton, pp 581-598

Sánchez-Galindo LM, Camenzind T, Maraun M, Scheu S (2019) Impacts of core rotation, defaunation and nitrogen addition on arbuscular mycorrhizal fungi, microorganisms and microarthropods in a tropical montane rainforest. Trop Ecol 60:350-361

Scheu S (1992) Automated measurement of the respiratory response of soil microcompartments: Active microbial biomass in earthworm faeces. Soil Biol Biochem 24:1113-1118

Scheu S, Illig J, Eissfeller V, et al (2008) The soil fauna of a tropical mountain rainforest in southern Ecuador: structure and functioning. In: Gradstein SR, Gansert D, Homeier J (eds) The tropical mountain forest. Patterns and processes in a biodiversity hotspots. pp 79-96

Scheu S, Ruess L, Bonkowski M (2005) Interactions and soil micro- and mesofauna. In: Buscot F, Varma A (eds) Microorganisms in soils: roles in genesis and functions. pp 253-275

Schinner F (1982) Soil microbial activities and litter decomposition related to altitude. Plant Soil 65:87-94

Scowcroft PG, Turner DR, Vitousek PM (2000) Decomposition of Metrosideros polymorpha leaf litter along elevational gradients in Hawaii. Glob Chang Biol 6:73-85

Seastedt TR (1984) The role of microarthropods in decomposition and mineralization processes. Annu Rev Entomol Vol 29 25-46

Silver WL, Miya RK (2001) Global patterns in root decomposition: Comparisons of climate and litter quality effects. Oecologia 129:407-419

Soethe N, Lehmann J, Engels C (2006) The vertical pattern of rooting and nutrient uptake at 
different altitudes of a south Ecuadorian montane forest. Plant Soil 286:287-299

Soethe N, Lehmann J, Engels C (2007) Carbon and nutrient stocks in roots of forests at different altitudes in the Ecuadorian Andes. J Trop Ecol 23:319-328

Strickland MS, Osburn E, Lauber C, et al (2009) Litter quality is in the eye of the beholder: Initial decomposition rates as a function of inoculum characteristics. Funct Ecol 23:627-636

Subías LS (2018) Listado sistemático, sinonímico y biogeográfico de los ácaros oribátidos (Acariformes: Oribatida ) del mundo (Excepto fósiles)(13 ${ }^{\mathrm{a}}$ actualización). http://www.ucm.es/info/zoo/Artropodos/Catalogo.pdf.

Swift M, Heal O, Anderson J (1979) Decomposition in Terrestrial Ecosystems. Oxford University Press

Tanner EVJ, Vltousek PM, Cuevas E (1998) Experimental investigation of nutrient limitation of forest growth on wet tropical mountains. Ecology 79:10-22

Ter Braak C, Smilauer P (2012) Canoco reference manual and user's guide: Software for ordination

Verhoef HA, Brussaard L (1990) Decomposition and nitrogen mineralization in natural and agroecosystems: the contribution of soil animals. Biogeochemistry 175-211

Wang S, Ruan H, Han Y (2010) Effects of microclimate, litter type, and mesh size on leaf litter decomposition along an elevation gradient in the Wuyi Mountains, China. Ecol Res 25:11131120 


\section{Appendix}

Appendix 1. Leaf and root litter mixtures per litterbags at the three altitudes $(1000,2000$ and $3000 \mathrm{~m})$.

\begin{tabular}{|c|c|c|c|c|}
\hline Site & Litter type & Species & Mass (g) & Total $(\mathrm{g})$ \\
\hline \multirow{6}{*}{$1000 \mathrm{~m}$} & \multirow{3}{*}{ Leaves } & Pouteria sp. & 5.0 & \multirow{3}{*}{10} \\
\hline & & Cecropia sp. & 3.0 & \\
\hline & & Mollinedia sp. & 2.0 & \\
\hline & \multirow{3}{*}{ Roots } & Small & 2.7 & \multirow{3}{*}{10} \\
\hline & & Medium & 4.8 & \\
\hline & & Large & 2.5 & \\
\hline \multirow{6}{*}{$2000 \mathrm{~m}$} & \multirow{3}{*}{ Leaves } & Graffenrieda emarginata & 5.0 & \multirow{3}{*}{10} \\
\hline & & Clusia sp. & 4.0 & \\
\hline & & Cavendishia zamorensis & 1.0 & \\
\hline & \multirow{3}{*}{ Roots } & Small & 4.4 & \multirow{3}{*}{10} \\
\hline & & Medium & 2.1 & \\
\hline & & Large & 3.5 & \\
\hline \multirow{6}{*}{$3000 \mathrm{~m}$} & \multirow{3}{*}{ Leaves } & Clusia sp. & 5.0 & \multirow{3}{*}{10} \\
\hline & & Graffenrieda emarginata & 4.0 & \\
\hline & & Hedyosmum sp. & 1.0 & \\
\hline & \multirow{3}{*}{ Roots } & Small & 3.4 & \multirow{3}{*}{10} \\
\hline & & Medium & 2.5 & \\
\hline & & Large & 4.1 & \\
\hline
\end{tabular}


Appendix 2. Microbial biomass $\left(\mathrm{C}_{\mathrm{mic}}\right)$ and basal respiration $(\mathrm{BR})$ in leaf and root litter in litterbags of $45 \mu \mathrm{m}, 1 \mathrm{~mm}$ and $4 \mathrm{~mm}$ mesh exposed at 1000, 2000 and $3000 \mathrm{~m}$ for 6 and 12 months. Values are means \pm SD.

\begin{tabular}{|c|c|c|c|c|c|c|}
\hline & & & \multicolumn{2}{|c|}{ Leaf litter } & \multicolumn{2}{|c|}{ Root litter } \\
\hline & & & $\begin{array}{c}\mathrm{C}_{\text {mic }} \\
{\left[\mathrm{mg} \mathrm{C}_{\text {mic }} \mathrm{g}^{-1} \mathrm{dw}\right]}\end{array}$ & $\begin{array}{c}\text { BR } \\
{\left[\mu l \mathrm{O}_{2} \mathrm{~g}^{-1} \mathrm{dw} \mathrm{h}^{-1}\right]}\end{array}$ & $\frac{C_{\text {mic }}}{\left[m g C_{m i c} g^{-1} d w\right]}$ & $\begin{array}{c}\text { BR } \\
{\left[\mu l \mathrm{O}_{2} \mathrm{~g}^{-1} \mathrm{dw} \mathbf{h}^{-1}\right]}\end{array}$ \\
\hline \multicolumn{7}{|l|}{ Time } \\
\hline \multicolumn{3}{|c|}{$\begin{array}{l}6 \text { months } \\
12 \text { months }\end{array}$} & $\begin{array}{l}6.48 \pm 1.29 \\
7.50 \pm 1.41\end{array}$ & $\begin{array}{l}74.46 \pm 18.28 \\
94.31 \pm 18.08\end{array}$ & $\begin{array}{l}5.63 \pm 1.43 \\
8.40 \pm 2.66\end{array}$ & $\begin{array}{c}52.18 \pm 18.26 \\
104.33 \pm 23.16\end{array}$ \\
\hline \multicolumn{7}{|c|}{ Mesh size } \\
\hline \multicolumn{3}{|c|}{$\begin{array}{l}45 \mu \mathrm{m} \\
1 \mathrm{~mm} \\
4 \mathrm{~mm}\end{array}$} & $\begin{array}{l}6.89 \pm 1.03 \\
6.22 \pm 1.40 \\
7.90 \pm 1.36\end{array}$ & $\begin{array}{l}92.71 \pm 18.55 \\
79.53 \pm 20.68 \\
80.91 \pm 21.01 \\
\end{array}$ & $\begin{array}{l}7.23 \pm 3.07 \\
6.76 \pm 2.27 \\
7.05 \pm 2.31\end{array}$ & $\begin{array}{l}77.21 \pm 34.54 \\
75.97 \pm 31.12 \\
81.58 \pm 36.20 \\
\end{array}$ \\
\hline \multicolumn{7}{|l|}{ Altitude } \\
\hline \multicolumn{3}{|c|}{$\begin{array}{l}1000 \mathrm{~m} \\
2000 \mathrm{~m} \\
3000 \mathrm{~m}\end{array}$} & $\begin{array}{l}7.01 \pm 1.61 \\
7.76 \pm 1.06 \\
6.22 \pm 1.18 \\
\end{array}$ & $\begin{array}{l}74.77 \pm 18.99 \\
94.39 \pm 20.90 \\
83.99 \pm 17.96 \\
\end{array}$ & $\begin{array}{l}9.36 \pm 2.65 \\
6.36 \pm 1.37 \\
5.31 \pm 1.35 \\
\end{array}$ & $\begin{array}{l}97.39 \pm 33.65 \\
73.18 \pm 28.48 \\
64.20 \pm 30.37 \\
\end{array}$ \\
\hline \multicolumn{7}{|c|}{ Time $\times$ mesh size } \\
\hline 6 months & \multicolumn{2}{|c|}{$\begin{array}{c}45 \mu \mathrm{m} \\
1 \mathrm{~mm} \\
4 \mathrm{~mm}\end{array}$} & $\begin{array}{l}6.37 \pm 0.87 \\
5.81 \pm 1.25 \\
7.28 \pm 1.37\end{array}$ & $\begin{array}{c}78.43 \pm 9.49 \\
66.60 \pm 16.37 \\
78.34 \pm 24.96\end{array}$ & $\begin{array}{l}6.03 \pm 1.62 \\
5.34 \pm 1.57 \\
5.50 \pm 1.12\end{array}$ & $\begin{array}{l}54.89 \pm 22.10 \\
51.04 \pm 18.26 \\
50.63 \pm 15.81 \\
\end{array}$ \\
\hline 12 months & \multicolumn{2}{|c|}{$\begin{array}{l}45 \mu \mathrm{m} \\
1 \mathrm{~mm} \\
4 \mathrm{~mm}\end{array}$} & $\begin{array}{l}7.36 \pm 0.97 \\
6.63 \pm 1.50 \\
8.52 \pm 1.09 \\
\end{array}$ & $\begin{array}{c}106.98 \pm 13.51 \\
92.47 \pm 16.25 \\
83.48 \pm 17.31 \\
\end{array}$ & $\begin{array}{l}8.43 \pm 3.76 \\
8.18 \pm 2.01 \\
8.59 \pm 2.18 \\
\end{array}$ & $\begin{array}{c}99.54 \pm 30.40 \\
100.89 \pm 18.05 \\
112.54 \pm 19.45\end{array}$ \\
\hline \multicolumn{7}{|c|}{ Time $\times$ altitude } \\
\hline 6 months & \multicolumn{2}{|c|}{$\begin{array}{l}1000 \mathrm{~m} \\
2000 \mathrm{~m} \\
3000 \mathrm{~m}\end{array}$} & $\begin{array}{l}5.90 \pm 1.13 \\
7.68 \pm 1.11 \\
5.88 \pm 0.73\end{array}$ & $\begin{array}{l}61.45 \pm 13.44 \\
89.29 \pm 18.02 \\
72.62 \pm 11.77 \\
\end{array}$ & $\begin{array}{l}7.07 \pm 1.21 \\
5.33 \pm 0.97 \\
4.49 \pm 0.59\end{array}$ & $\begin{array}{c}68.15 \pm 17.25 \\
50.35 \pm 15.24 \\
38.05 \pm 6.22\end{array}$ \\
\hline 12 months & \multicolumn{2}{|c|}{$\begin{array}{l}1000 \mathrm{~m} \\
2000 \mathrm{~m} \\
3000 \mathrm{~m}\end{array}$} & $\begin{array}{l}8.13 \pm 1.21 \\
7.84 \pm 1.08 \\
6.55 \pm 1.48\end{array}$ & $\begin{array}{l}88.10 \pm 13.65 \\
99.48 \pm 23.35 \\
95.35 \pm 16.01 \\
\end{array}$ & $\begin{array}{c}11.65 \pm 1.26 \\
7.40 \pm 0.81 \\
6.14 \pm 1.41 \\
\end{array}$ & $\begin{array}{c}126.62 \pm 13.60 \\
96.01 \pm 17.87 \\
90.35 \pm 19.55\end{array}$ \\
\hline \multicolumn{7}{|c|}{ Mesh size $\times$ altitude } \\
\hline $45 \mu \mathrm{m}$ & \multicolumn{2}{|c|}{$\begin{array}{l}1000 \mathrm{~m} \\
2000 \mathrm{~m} \\
3000 \mathrm{~m}\end{array}$} & $\begin{array}{l}7.18 \pm 0.89 \\
7.34 \pm 1.03 \\
6.07 \pm 0.77\end{array}$ & $\begin{array}{l}88.15 \pm 18.09 \\
98.62 \pm 20.28 \\
91.35 \pm 19.04\end{array}$ & $\begin{array}{c}10.50 \pm 2.96 \\
6.42 \pm 1.44 \\
4.77 \pm 0.54\end{array}$ & $\begin{array}{c}109.46 \pm 30.77 \\
66.68 \pm 27.52 \\
55.50 \pm 20.10\end{array}$ \\
\hline $1 \mathrm{~mm}$ & \multicolumn{2}{|c|}{$\begin{array}{l}1000 \mathrm{~m} \\
2000 \mathrm{~m} \\
3000 \mathrm{~m}\end{array}$} & $\begin{array}{l}5.83 \pm 1.51 \\
7.49 \pm 0.97 \\
5.35 \pm 0.68\end{array}$ & $\begin{array}{c}67.66 \pm 20.88 \\
92.33 \pm 23.60 \\
78.62 \pm 9.70\end{array}$ & $\begin{array}{l}9.02 \pm 1.90 \\
5.77 \pm 1.59 \\
5.49 \pm 1.47\end{array}$ & $\begin{array}{l}95.16 \pm 28.32 \\
64.23 \pm 23.55 \\
68.51 \pm 35.51\end{array}$ \\
\hline $4 \mathrm{~mm}$ & \multicolumn{2}{|c|}{$\begin{array}{l}1000 \mathrm{~m} \\
2000 \mathrm{~m} \\
3000 \mathrm{~m}\end{array}$} & $\begin{array}{l}8.04 \pm 1.67 \\
8.45 \pm 0.99 \\
7.22 \pm 1.26\end{array}$ & $\begin{array}{l}68.51 \pm 11.83 \\
92.21 \pm 22.02 \\
82.01 \pm 23.15\end{array}$ & $\begin{array}{l}8.56 \pm 3.00 \\
6.89 \pm 1.04 \\
5.69 \pm 1.77\end{array}$ & $\begin{array}{l}87.54 \pm 42.46 \\
88.63 \pm 31.83 \\
68.58 \pm 36.52 \\
\end{array}$ \\
\hline \multicolumn{7}{|c|}{ Time $\times$ mesh size $\times$ Altitude } \\
\hline \multirow[t]{2}{*}{6 months } & $45 \mu \mathrm{m}$ & $\begin{array}{l}1000 \mathrm{~m} \\
2000 \mathrm{~m} \\
3000 \mathrm{~m}\end{array}$ & $\begin{array}{l}6.62 \pm 0.55 \\
6.98 \pm 0.78 \\
5.52 \pm 0.60\end{array}$ & $\begin{array}{l}73.23 \pm 9.53 \\
87.46 \pm 6.52 \\
74.60 \pm 6.51\end{array}$ & $\begin{array}{l}7.93 \pm 1.28 \\
5.26 \pm 0.69 \\
4.90 \pm 0.40\end{array}$ & $\begin{array}{c}82.97 \pm 3.69 \\
43.13 \pm 10.54 \\
38.55 \pm 6.15\end{array}$ \\
\hline & $1 \mathrm{~mm}$ & $1000 \mathrm{~m}$ & $4.47 \pm 0.29$ & $48.82 \pm 2.23$ & $7.37 \pm 0.16$ & $71.59 \pm 15.91$ \\
\hline
\end{tabular}




\begin{tabular}{|c|c|c|c|c|c|c|}
\hline & & $\begin{array}{l}2000 \mathrm{~m} \\
3000 \mathrm{~m}\end{array}$ & $\begin{array}{l}7.21 \pm 0.25 \\
5.74 \pm 0.71\end{array}$ & $\begin{array}{c}72.29 \pm 9.90 \\
78.69 \pm 15.08\end{array}$ & $\begin{array}{l}4.36 \pm 0.18 \\
4.30 \pm 0.70\end{array}$ & $\begin{array}{l}43.37 \pm 4.33 \\
38.15 \pm 9.50\end{array}$ \\
\hline & $4 \mathrm{~mm}$ & $\begin{array}{l}1000 \mathrm{~m} \\
2000 \mathrm{~m} \\
3000 \mathrm{~m}\end{array}$ & $\begin{array}{l}6.61 \pm 0.42 \\
8.85 \pm 1.06 \\
6.39 \pm 0.82\end{array}$ & $\begin{array}{c}62.30 \pm 13.34 \\
108.13 \pm 13.68 \\
64.58 \pm 11.24\end{array}$ & $\begin{array}{l}5.89 \pm 0.92 \\
6.35 \pm 0.49 \\
4.26 \pm 0.57\end{array}$ & $\begin{array}{c}49.89 \pm 8.71 \\
64.55 \pm 18.58 \\
37.44 \pm 5.05\end{array}$ \\
\hline \multirow{3}{*}{12 months } & $45 \mu \mathrm{m}$ & $\begin{array}{l}1000 \mathrm{~m} \\
2000 \mathrm{~m} \\
3000 \mathrm{~m}\end{array}$ & $\begin{array}{l}7.75 \pm 0.86 \\
7.71 \pm 1.29 \\
6.63 \pm 1.45\end{array}$ & $\begin{array}{c}103.08 \pm 7.71 \\
109.78 \pm 24.73 \\
108.09 \pm 4.75\end{array}$ & $\begin{array}{c}13.06 \pm 0.76 \\
7.59 \pm 0.80 \\
4.64 \pm 0.72\end{array}$ & $\begin{array}{r}135.95 \pm 15.77 \\
90.23 \pm 10.89 \\
72.45 \pm 10.52\end{array}$ \\
\hline & $1 \mathrm{~mm}$ & $\begin{array}{l}1000 \mathrm{~m} \\
2000 \mathrm{~m} \\
3000 \mathrm{~m}\end{array}$ & $\begin{array}{l}7.18 \pm 0.40 \\
7.76 \pm 1.44 \\
4.96 \pm 0.44\end{array}$ & $\begin{array}{c}86.49 \pm 4.51 \\
112.37 \pm 9.46 \\
78.54 \pm 2.82\end{array}$ & $\begin{array}{c}10.68 \pm 0.93 \\
7.18 \pm 0.55 \\
6.67 \pm 0.84\end{array}$ & $\begin{array}{c}118.72 \pm 9.24 \\
85.09 \pm 7.89 \\
98.87 \pm 17.27\end{array}$ \\
\hline & $4 \mathrm{~mm}$ & $\begin{array}{l}1000 \mathrm{~m} \\
2000 \mathrm{~m} \\
3000 \mathrm{~m}\end{array}$ & $\begin{array}{l}9.46 \pm 0.85 \\
8.04 \pm 0.92 \\
8.06 \pm 1.09\end{array}$ & $\begin{array}{c}74.71 \pm 7.50 \\
76.29 \pm 16.28 \\
99.43 \pm 17.40\end{array}$ & $\begin{array}{c}11.23 \pm 0.51 \\
7.43 \pm 1.26 \\
7.11 \pm 1.20\end{array}$ & $\begin{array}{c}125.19 \pm 13.35 \\
112.70 \pm 21.19 \\
99.73 \pm 19.98\end{array}$ \\
\hline
\end{tabular}


Appendix 3. Effect of altitude on (A) microbial biomass $\left(\mathrm{C}_{\mathrm{mic}}\right)$ and (B) basal respiration (BR) after 6 and 12 months. Values are means \pm SE. For each litter type, bars marked with different letters within each harvesting time differ significantly (Tukey's HSD tests, $\mathrm{p}<$ $0.05)$.
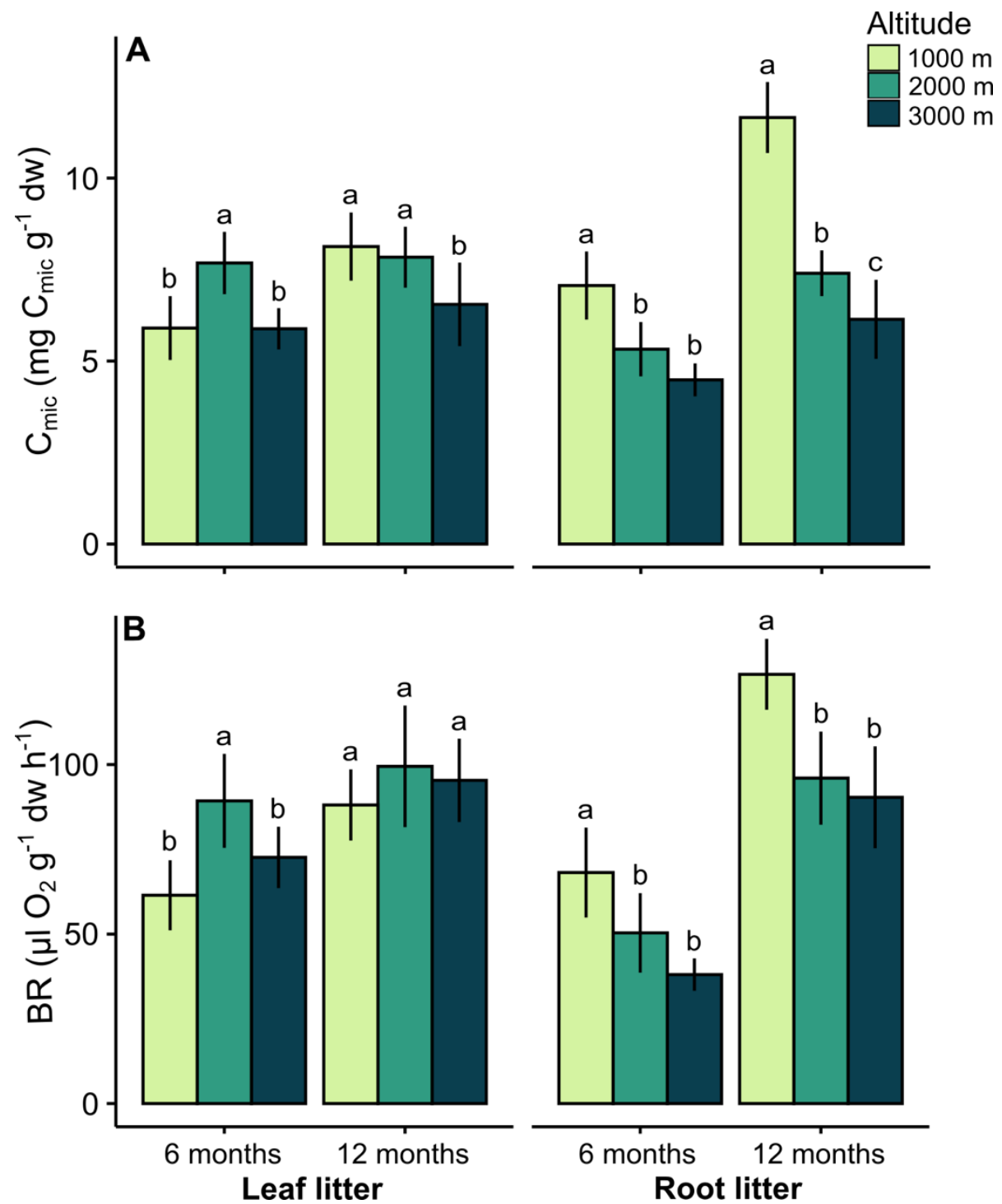
Appendix 4. Collembola and Oribatida abundance and Oribatida species richness in leaf and root litter in litterbags of $45 \mu \mathrm{m}, 1 \mathrm{~mm}$ and $4 \mathrm{~mm}$ mesh exposed at 1000, 2000 and $3000 \mathrm{~m}$ for 6 and 12 months. Values are means \pm SD.

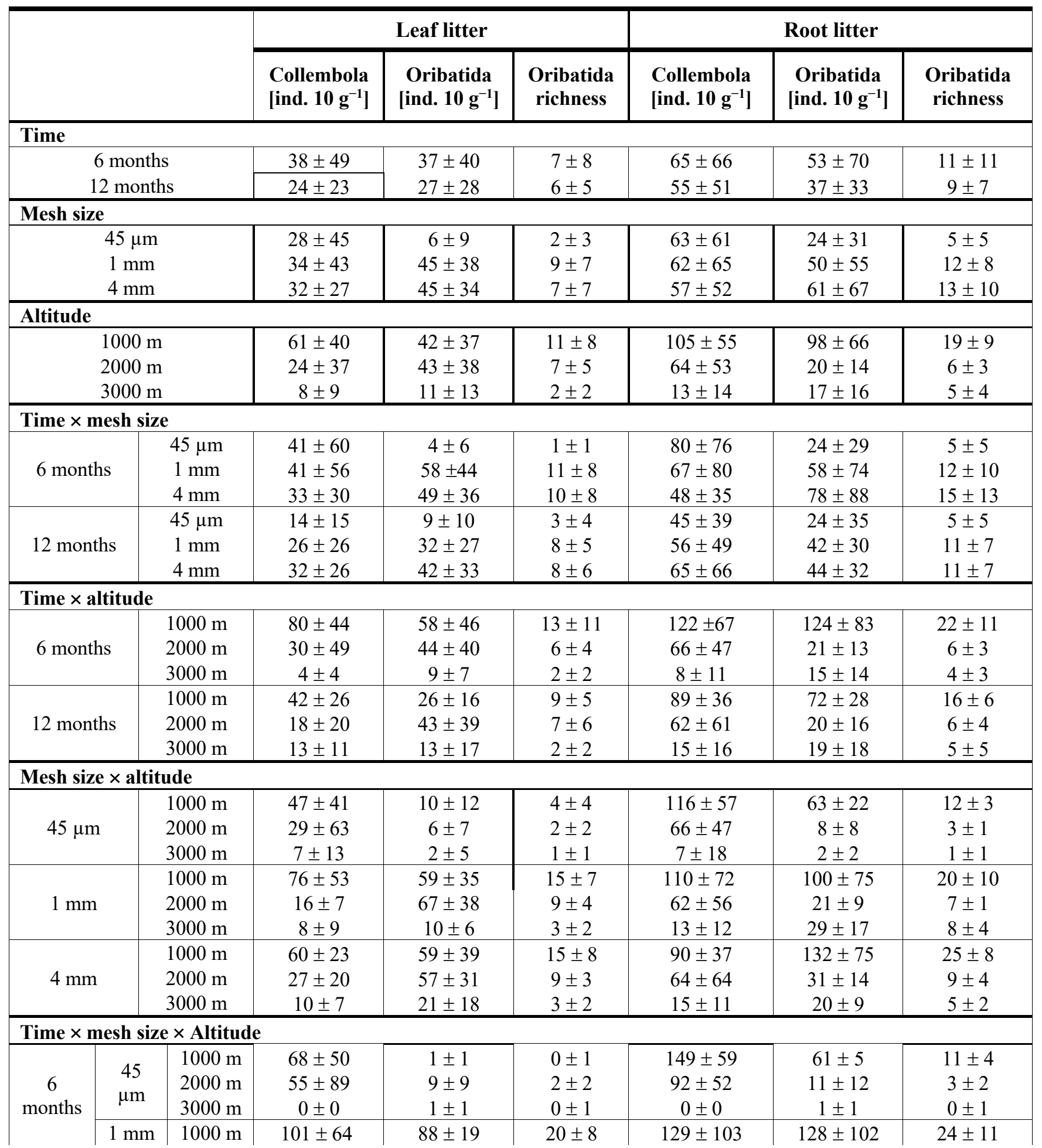


Chapter 3

\begin{tabular}{|c|c|c|c|c|c|c|c|c|}
\hline & & $\begin{array}{l}2000 \mathrm{~m} \\
3000 \mathrm{~m}\end{array}$ & $\begin{array}{c}17 \pm 6 \\
5 \pm 3\end{array}$ & $\begin{array}{c}75 \pm 50 \\
11 \pm 5 \\
\end{array}$ & $\begin{array}{l}8 \pm 3 \\
4 \pm 1\end{array}$ & $\begin{array}{c}68 \pm 61 \\
5 \pm 3\end{array}$ & $\begin{array}{l}23 \pm 10 \\
23 \pm 17\end{array}$ & $\begin{array}{l}7 \pm 2 \\
5 \pm 2 \\
\end{array}$ \\
\hline & $4 \mathrm{~mm}$ & $\begin{array}{l}1000 \mathrm{~m} \\
2000 \mathrm{~m} \\
3000 \mathrm{~m}\end{array}$ & $\begin{array}{c}72 \pm 8 \\
18 \pm 9 \\
8 \pm 4\end{array}$ & $\begin{array}{c}86 \pm 28 \\
47 \pm 24 \\
14 \pm 6\end{array}$ & $\begin{array}{c}19 \pm 6 \\
8 \pm 1 \\
3 \pm 1\end{array}$ & $\begin{array}{c}87 \pm 21 \\
37 \pm 9 \\
20 \pm 14\end{array}$ & $\begin{array}{c}184 \pm 74 \\
28 \pm 14 \\
21 \pm 7\end{array}$ & $\begin{array}{c}32 \pm 6 \\
8 \pm 4 \\
5 \pm 2\end{array}$ \\
\hline \multirow{3}{*}{$\begin{array}{c}12 \\
\text { months }\end{array}$} & $\begin{array}{l}45 \\
\mu \mathrm{m}\end{array}$ & $\begin{array}{l}1000 \mathrm{~m} \\
2000 \mathrm{~m} \\
3000 \mathrm{~m} \\
\end{array}$ & $\begin{aligned} & 25 \pm 16 \\
& 3 \pm 3 \\
& 15 \pm 16 \\
&\end{aligned}$ & $\begin{array}{c}19 \pm 11 \\
3 \pm 3 \\
4 \pm 7 \\
\end{array}$ & $\begin{array}{l}7 \pm 4 \\
2 \pm 2 \\
1 \pm 2 \\
\end{array}$ & $\begin{array}{l}82 \pm 37 \\
39 \pm 26 \\
15 \pm 25 \\
\end{array}$ & $\begin{array}{c}65 \pm 34 \\
5 \pm 3 \\
3 \pm 3\end{array}$ & $\begin{array}{l}12 \pm 3 \\
3 \pm 2 \\
1 \pm 2 \\
\end{array}$ \\
\hline & $1 \mathrm{~mm}$ & $\begin{array}{l}1000 \mathrm{~m} \\
2000 \mathrm{~m} \\
3000 \mathrm{~m}\end{array}$ & $\begin{array}{c}51 \pm 32 \\
15 \pm 9 \\
11 \pm 12 \\
\end{array}$ & $\begin{array}{c}29 \pm 8 \\
59 \pm 31 \\
9 \pm 8\end{array}$ & $\begin{array}{c}11 \pm 2 \\
10 \pm 5 \\
2 \pm 2 \\
\end{array}$ & $\begin{array}{l}92 \pm 38 \\
55 \pm 65 \\
21 \pm 14\end{array}$ & $\begin{array}{c}71 \pm 33 \\
19 \pm 8 \\
34 \pm 19 \\
\end{array}$ & $\begin{array}{c}17 \pm 8 \\
6 \pm 2 \\
10 \pm 4 \\
\end{array}$ \\
\hline & $4 \mathrm{~mm}$ & $\begin{array}{l}1000 \mathrm{~m} \\
2000 \mathrm{~m} \\
3000 \mathrm{~m}\end{array}$ & $\begin{array}{l}48 \pm 30 \\
37 \pm 25 \\
12 \pm 11\end{array}$ & $\begin{array}{l}31 \pm 27 \\
66 \pm 40 \\
27 \pm 25\end{array}$ & $\begin{array}{c}10 \pm 8 \\
10 \pm 5 \\
3 \pm 3\end{array}$ & $\begin{array}{c}93 \pm 48 \\
91 \pm 90 \\
10 \pm 6\end{array}$ & $\begin{array}{l}80 \pm 24 \\
34 \pm 17 \\
19 \pm 13\end{array}$ & $\begin{array}{c}19 \pm 2 \\
9 \pm 4 \\
5 \pm 3\end{array}$ \\
\hline
\end{tabular}


Appendix 5. List of Oribatida species, abbreviations used in Figure 5 and their abundance in leaf and root litter.

\begin{tabular}{|c|c|c|c|c|c|c|c|c|}
\hline No. & Species & Abbreviation & Leaves & $\begin{array}{c}\text { Included } \\
\text { in CCA } \\
\text { leaves }\end{array}$ & $\begin{array}{l}\text { Abundance } \\
\text { in leaves }\end{array}$ & Roots & $\begin{array}{c}\text { Included } \\
\text { in CCA } \\
\text { roots }\end{array}$ & $\begin{array}{l}\text { Abundance } \\
\text { in roots }\end{array}$ \\
\hline 1 & Acrogalumna cubana & & $\mathrm{x}$ & - & 2 & - & - & 0 \\
\hline 2 & Acrogalumna $n$ sp 1 & AcrogSp1 & $\mathrm{x}$ & $\mathrm{x}$ & 6 & $\mathrm{x}$ & - & 2 \\
\hline 3 & Amazoppia tricuspidata & & - & - & 0 & $\mathrm{x}$ & - & 2 \\
\hline 4 & Arceremaeus incaensis & & $\mathrm{x}$ & - & 2 & - & - & 0 \\
\hline 5 & $\begin{array}{l}\text { Arcoppia } \\
\text { dechambrierorum }\end{array}$ & ArcpDech & - & - & 0 & $\mathrm{x}$ & $\mathrm{x}$ & 3 \\
\hline 6 & Arcoppia tripartita & & - & - & 0 & $\mathrm{x}$ & - & 1 \\
\hline 7 & Beckiella elongata & & $\mathrm{x}$ & - & 1 & - & - & 0 \\
\hline 8 & Brachioppia deliciosa & BracDelc & $\mathrm{x}$ & $\mathrm{x}$ & 6 & $\mathrm{x}$ & $\mathrm{x}$ & 13 \\
\hline 9 & Brachioppia $n$ sp 2 & & - & - & 0 & $\mathrm{x}$ & - & 1 \\
\hline 10 & Brachioppia sp 3 & BrachSp3 & $\mathrm{x}$ & - & 2 & $\mathrm{x}$ & $\mathrm{x}$ & 22 \\
\hline 11 & Brachioppiella $n$ sp 2 & BrachSp2 & - & - & 0 & $\mathrm{x}$ & $\mathrm{x}$ & 46 \\
\hline 12 & $\begin{array}{l}\text { Campachipteria } \\
\text { brevisetosa }\end{array}$ & & $\mathrm{x}$ & - & 1 & - & - & 0 \\
\hline 13 & Caudamaeolus petalus & CaudPetl & - & - & 0 & $\mathrm{x}$ & $\mathrm{x}$ & 3 \\
\hline 14 & Ceratorchestes globosus & & $\mathrm{x}$ & - & 2 & - & - & 0 \\
\hline 15 & Ceratorchestes sp 1 & & $\mathrm{x}$ & - & 1 & - & - & 0 \\
\hline 16 & Ceratozetes $n s p 1$ & & $\mathrm{x}$ & - & 1 & - & - & 0 \\
\hline 17 & Cosmozetes $n$ sp 2 & & $\mathrm{x}$ & - & 1 & - & - & 0 \\
\hline 18 & Cosmozetes $n$ sp 3 & & $\mathrm{x}$ & - & 1 & - & - & 0 \\
\hline 19 & Cosmozetes reticulatus & CosmRetc & $\mathrm{x}$ & $\mathrm{x}$ & 35 & $\mathrm{x}$ & $\mathrm{x}$ & 37 \\
\hline 20 & Crotonia reticulata & & $\mathrm{x}$ & - & 1 & - & - & 0 \\
\hline 21 & Cultroribula zicsii & CultZics & $\mathrm{x}$ & $\mathrm{x}$ & 7 & $\mathrm{x}$ & $\mathrm{x}$ & 6 \\
\hline 22 & Cyrthermannia florence & CyrtFlor & - & - & 0 & $\mathrm{x}$ & $\mathrm{x}$ & 12 \\
\hline 23 & Damaeus flagellatus & DamaFlag & $\mathrm{x}$ & $\mathrm{x}$ & 5 & $\mathrm{x}$ & - & 1 \\
\hline 24 & Dynatozetes $n s p 1$ & & - & - & 0 & $\mathrm{x}$ & - & 2 \\
\hline 25 & Enarthronota $n s p 1$ & & $\mathrm{x}$ & - & 1 & $\mathrm{x}$ & - & 2 \\
\hline 26 & Eohypochthonius gracilis & EohpGrac & $\mathrm{x}$ & $\mathrm{x}$ & 5 & $\mathrm{x}$ & $\mathrm{x}$ & 39 \\
\hline 27 & Eohypochthonius $n$ sp 1 & EohypSp1 & $\mathrm{x}$ & $\mathrm{x}$ & 3 & $\mathrm{x}$ & $\mathrm{x}$ & 11 \\
\hline 28 & Epidamaeus meridianus & & - & - & 0 & $\mathrm{x}$ & - & 1 \\
\hline 29 & Epieremulus granulatus & EpieGran & $\mathrm{x}$ & $\mathrm{x}$ & 7 & $\mathrm{x}$ & - & 1 \\
\hline 30 & Epieremulus longiseta & & $\mathrm{x}$ & - & 2 & - & - & 0 \\
\hline 31 & Epieremulus $n s p 1$ & EpierSp1 & $\mathrm{x}$ & $\mathrm{x}$ & 10 & - & - & 0 \\
\hline
\end{tabular}




\begin{tabular}{|c|c|c|c|c|c|c|c|c|}
\hline No. & Species & Abbreviation & Leaves & $\begin{array}{c}\text { Included } \\
\text { in CCA } \\
\text { leaves }\end{array}$ & $\begin{array}{l}\text { Abundance } \\
\text { in leaves }\end{array}$ & Roots & $\begin{array}{l}\text { Included } \\
\text { in CCA } \\
\text { roots }\end{array}$ & $\begin{array}{l}\text { Abundance } \\
\text { in roots }\end{array}$ \\
\hline 32 & $\begin{array}{l}\text { Epilohmannia minuta } \\
\text { minuta }\end{array}$ & EplMinMn & - & - & 0 & $\mathrm{x}$ & $\mathrm{x}$ & 6 \\
\hline 33 & Eremobelba foliata & EremFoli & - & - & 0 & $\mathrm{x}$ & $\mathrm{x}$ & 5 \\
\hline 34 & Eremulus brasiliensis & EremBras & $\mathrm{x}$ & - & 3 & - & - & 0 \\
\hline 35 & Eremulus rigidisetosus & EremRigd & $\mathrm{x}$ & $\mathrm{x}$ & 7 & $\mathrm{x}$ & $\mathrm{x}$ & 5 \\
\hline 36 & $\begin{array}{l}\text { Fenestrobelba } \\
\text { subcomplexa }\end{array}$ & FensSubc & $\mathrm{x}$ & $\mathrm{x}$ & 8 & $\mathrm{x}$ & $\mathrm{x}$ & 6 \\
\hline 37 & Fosseremus laciniatus & FossLacn & $\mathrm{x}$ & $\mathrm{x}$ & 3 & $\mathrm{x}$ & $\mathrm{x}$ & 8 \\
\hline 38 & Galumna flabellifera & GalmFlab & $\mathrm{x}$ & $\mathrm{x}$ & 10 & $\mathrm{x}$ & $\mathrm{x}$ & 5 \\
\hline 39 & Galumna $n$ sp 1 & & - & - & 0 & $\mathrm{x}$ & - & 1 \\
\hline 40 & Gehypochthonius $n$ sp 1 & & $\mathrm{x}$ & - & 1 & $\mathrm{x}$ & - & 2 \\
\hline 41 & Gitella variabilis & GitlVari & - & - & 0 & $\mathrm{x}$ & $\mathrm{x}$ & 6 \\
\hline 42 & Gittella maxima & & - & - & 0 & $\mathrm{x}$ & - & 2 \\
\hline 43 & Gittella minor & GittMinr & - & - & 0 & $\mathrm{x}$ & $\mathrm{x}$ & 3 \\
\hline 44 & Gittella $n$ sp 1 & GittlSp1 & $\mathrm{x}$ & - & 1 & $\mathrm{x}$ & $\mathrm{x}$ & 9 \\
\hline 45 & Hammerella parasufflata & HammPars & - & - & 0 & $\mathrm{x}$ & $\mathrm{x}$ & 5 \\
\hline 46 & Haplobelba $n$ sp 1 & & - & - & 0 & $\mathrm{x}$ & - & 1 \\
\hline 47 & Haplobelba simplex & HaplSimp & $\mathrm{x}$ & $\mathrm{x}$ & 4 & $\mathrm{x}$ & $\mathrm{x}$ & 9 \\
\hline 48 & $\begin{array}{l}\text { Haplozetes } \\
\text { paraminimicoma }\end{array}$ & HaplParm & $\mathrm{x}$ & - & 1 & $\mathrm{x}$ & $\mathrm{x}$ & 10 \\
\hline 49 & Hemileius hemileiformis & HemlHeml & $\mathrm{x}$ & $\mathrm{x}$ & 18 & $\mathrm{x}$ & $\mathrm{x}$ & 6 \\
\hline 50 & Hemileius $n$ sp 1 & HemilSp1 & $\mathrm{x}$ & $\mathrm{x}$ & 28 & $\mathrm{x}$ & - & 2 \\
\hline 51 & Hemileius parvus & & $\mathrm{x}$ & - & 1 & $\mathrm{x}$ & - & 2 \\
\hline 52 & Heminothrus castaneus & & $\mathrm{x}$ & - & 1 & - & - & 0 \\
\hline 53 & $\begin{array}{l}\text { Hermannobates } \\
\text { bifurcatus }\end{array}$ & & $\mathrm{x}$ & - & 1 & $\mathrm{x}$ & - & 1 \\
\hline 54 & $\begin{array}{l}\text { Hermannobates } \\
\text { monstruosus }\end{array}$ & & - & - & 0 & $\mathrm{x}$ & - & 1 \\
\hline 55 & Hermannobates $n$ sp 6 & HermnSp6 & - & - & 0 & $\mathrm{x}$ & $\mathrm{x}$ & 3 \\
\hline 56 & Kokoppia dudichi & & $\mathrm{x}$ & - & 1 & $\mathrm{x}$ & - & 2 \\
\hline 57 & Kokoppia euramosa & & - & - & 0 & $\mathrm{x}$ & - & 2 \\
\hline 58 & Lanceoppia $n$ sp 1 & LanceSp1 & $\mathrm{x}$ & $\mathrm{x}$ & 3 & - & - & 0 \\
\hline 59 & Lanceoppia $n$ sp 2 & LanceSp2 & $\mathrm{x}$ & $\mathrm{x}$ & 6 & - & - & 0 \\
\hline 60 & Lanceoppia zicsica & LancZics & $\mathrm{x}$ & $\mathrm{x}$ & 3 & - & - & 0 \\
\hline 61 & Lasiobelba chistyakovi & LasiChis & $\mathrm{x}$ & - & 1 & $\mathrm{x}$ & $\mathrm{x}$ & 41 \\
\hline 62 & Lichochthonius mollis & & - & - & 0 & $\mathrm{x}$ & - & 1 \\
\hline 63 & Licnozetes granulatus & LicnGran & $\mathrm{x}$ & $\mathrm{x}$ & 10 & $\mathrm{x}$ & $\mathrm{x}$ & 15 \\
\hline 64 & Liebstadia $n$ sp 1 & LiebsSpl & $\mathrm{x}$ & $\mathrm{x}$ & 9 & $\mathrm{x}$ & $\mathrm{x}$ & 3 \\
\hline 65 & Liebstadia n sp 1.1 & LiebSp.1a & $\mathrm{x}$ & $\mathrm{x}$ & 5 & - & - & 0 \\
\hline
\end{tabular}




\begin{tabular}{|c|c|c|c|c|c|c|c|c|}
\hline No. & Species & Abbreviation & Leaves & $\begin{array}{c}\text { Included } \\
\text { in CCA } \\
\text { leaves }\end{array}$ & $\begin{array}{l}\text { Abundance } \\
\text { in leaves }\end{array}$ & Roots & $\begin{array}{c}\text { Included } \\
\text { in CCA } \\
\text { roots }\end{array}$ & $\begin{array}{l}\text { Abundance } \\
\text { in roots }\end{array}$ \\
\hline 66 & Liebstadia $n$ sp 2 & & $\mathrm{x}$ & - & 2 & - & - & 0 \\
\hline 67 & Machadobelba $n$ sp 1 & MachdSpl & - & - & 0 & $\mathrm{x}$ & $\mathrm{x}$ & 5 \\
\hline 68 & Malacoangelia remigera & MalcRemg & - & - & 0 & $\mathrm{x}$ & $\mathrm{x}$ & 7 \\
\hline 69 & $\begin{array}{l}\text { Malaconothrus } \\
\text { monodactylus }\end{array}$ & MalcMond & $\mathrm{x}$ & $\mathrm{x}$ & 5 & $\mathrm{x}$ & $\mathrm{x}$ & 5 \\
\hline 70 & Malaconothrus n sp 3 & & $\mathrm{x}$ & - & 1 & $\mathrm{x}$ & - & 2 \\
\hline 71 & Malaconothrus n sp 4 & & - & - & 0 & $\mathrm{x}$ & - & 2 \\
\hline 72 & Malaconothrus n sp 5 & MalacSp5 & $\mathrm{x}$ & $\mathrm{x}$ & 6 & - & - & 0 \\
\hline 73 & Microtegeus borhidii & MicrBorh & $\mathrm{x}$ & $\mathrm{x}$ & 12 & - & - & 0 \\
\hline 74 & Microtegeus similis & MicrSiml & $\mathrm{x}$ & $\mathrm{x}$ & 5 & $\mathrm{x}$ & - & 1 \\
\hline 75 & $\begin{array}{l}\text { Nanhermannia } \\
\text { elegantissima }\end{array}$ & NanhEleg & $\mathrm{x}$ & - & 2 & $\mathrm{x}$ & $\mathrm{x}$ & 12 \\
\hline 76 & $\begin{array}{l}\text { Nanhermannia nana } \\
\text { form } 1\end{array}$ & NanhNana & - & - & 0 & $\mathrm{x}$ & $\mathrm{x}$ & 13 \\
\hline 77 & $\begin{array}{l}\text { Neoamerioppia } \\
\text { longiclava }\end{array}$ & NeoaLong & $\mathrm{x}$ & $\mathrm{x}$ & 132 & $\mathrm{x}$ & - & 1 \\
\hline 78 & $\begin{array}{l}\text { Neoamerioppia } \\
\text { longicoma }\end{array}$ & NeoaLogc & $\mathrm{x}$ & $\mathrm{x}$ & 8 & - & - & 0 \\
\hline 79 & Neoamerioppia rotunda & NeoaRotn & $\mathrm{x}$ & $\mathrm{x}$ & 24 & - & - & 0 \\
\hline 80 & $\begin{array}{l}\text { Neoamrioppia } \\
\text { espelatiarum }\end{array}$ & NeoaEspl & $\mathrm{x}$ & $\mathrm{x}$ & 3 & - & - & 0 \\
\hline 81 & $\begin{array}{l}\text { Neoctenogalumna } \\
\text { longiciliata }\end{array}$ & & $\mathrm{x}$ & - & 1 & - & - & 0 \\
\hline 82 & $\begin{array}{l}\text { Neosuctobelba } \\
\text { transitoria }\end{array}$ & & $\mathrm{x}$ & - & 2 & - & - & 0 \\
\hline 83 & Opiella nova & OpieNova & $\mathrm{x}$ & $\mathrm{x}$ & 27 & $\mathrm{x}$ & $\mathrm{x}$ & 36 \\
\hline 84 & Oribatella $n$ sp 2 & OribtSp2 & $\mathrm{x}$ & $\mathrm{x}$ & 10 & $\mathrm{x}$ & $\mathrm{x}$ & 4 \\
\hline 85 & Oripoda $n$ sp 1 & OripdSp1 & $\mathrm{x}$ & $\mathrm{x}$ & 3 & - & - & 0 \\
\hline 86 & Orthozetes bidentatus & OrthBidn & $\mathrm{x}$ & - & 2 & $\mathrm{x}$ & $\mathrm{x}$ & 20 \\
\hline 87 & Oxyoppia polynesia & OxyoPoln & $\mathrm{x}$ & $\mathrm{x}$ & 7 & - & - & 0 \\
\hline 88 & Parhypochthonius $n$ sp 1 & & $\mathrm{x}$ & - & 1 & - & - & 0 \\
\hline 89 & Pergalumna australis & & - & - & 0 & $\mathrm{x}$ & - & 1 \\
\hline 90 & Pergalumna sura & PergSura & $\mathrm{x}$ & $\mathrm{x}$ & 4 & $\mathrm{x}$ & $\mathrm{x}$ & 5 \\
\hline 91 & $\begin{array}{l}\text { Perscheloribates } \\
\text { luminosus }\end{array}$ & & $\mathrm{x}$ & - & 2 & $\mathrm{x}$ & - & 2 \\
\hline 92 & $\begin{array}{l}\text { Perscheloribates } \\
\text { paratzitzikamaensis }\end{array}$ & & - & - & 0 & $\mathrm{x}$ & - & 2 \\
\hline 93 & $\begin{array}{l}\text { Plenotocepheus } \\
\text { neotropicus }\end{array}$ & PlenNeot & $\mathrm{x}$ & - & 2 & $\mathrm{x}$ & $\mathrm{x}$ & 8 \\
\hline 94 & $\begin{array}{l}\text { Protoribates } \\
\text { ecuadoriensis }\end{array}$ & ProtEcua & $\mathrm{x}$ & - & 2 & $\mathrm{x}$ & $\mathrm{x}$ & 13 \\
\hline 95 & Protoribates n sp 3 & ProtrSp3 & $\mathrm{x}$ & $\mathrm{x}$ & 4 & $\mathrm{x}$ & $\mathrm{x}$ & 25 \\
\hline 96 & Protoribates $n$ sp 4 & & - & - & 0 & $\mathrm{x}$ & - & 1 \\
\hline
\end{tabular}




\begin{tabular}{|c|c|c|c|c|c|c|c|c|}
\hline No. & Species & Abbreviation & Leaves & $\begin{array}{c}\text { Included } \\
\text { in CCA } \\
\text { leaves }\end{array}$ & $\begin{array}{l}\text { Abundance } \\
\text { in leaves }\end{array}$ & Roots & $\begin{array}{l}\text { Included } \\
\text { in CCA } \\
\text { roots }\end{array}$ & $\begin{array}{l}\text { Abundance } \\
\text { in roots }\end{array}$ \\
\hline 97 & $\begin{array}{l}\text { Protoribates } \\
\text { paracapucinus }\end{array}$ & ProtParc & $\mathrm{x}$ & $\mathrm{x}$ & 8 & $\mathrm{x}$ & $\mathrm{x}$ & 29 \\
\hline 98 & Pulchroppia n sp 1 & & $\mathrm{x}$ & - & 1 & - & - & 0 \\
\hline 99 & $\begin{array}{l}\text { Ramusella } \\
\text { puertomonttensis }\end{array}$ & RamsPuer & - & - & 0 & $\mathrm{x}$ & $\mathrm{x}$ & 3 \\
\hline 100 & Rhynchoribates mirus & RhynMirs & $\mathrm{x}$ & - & 2 & $\mathrm{x}$ & $\mathrm{x}$ & 7 \\
\hline 101 & Rhynchoribates $n$ sp 1 & & $\mathrm{x}$ & - & 1 & $\mathrm{x}$ & - & 1 \\
\hline 102 & Rioppia comteae & RiopComt & $\mathrm{x}$ & - & 2 & $\mathrm{x}$ & $\mathrm{x}$ & 6 \\
\hline 103 & Rostrozetes carinatus & RostCarn & $\mathrm{x}$ & $\mathrm{x}$ & 41 & $\mathrm{x}$ & - & 1 \\
\hline 104 & Rostrozetes glaber & & $\mathrm{x}$ & - & 1 & $\mathrm{x}$ & - & 1 \\
\hline 105 & $\begin{array}{l}\text { Rostrozetes ovulum } \\
\text { ovulum }\end{array}$ & RosOvlOv & $\mathrm{x}$ & $\mathrm{x}$ & 11 & $\mathrm{x}$ & $\mathrm{x}$ & 39 \\
\hline 106 & $\begin{array}{l}\text { Rostrozetes ovulum } \\
\text { poensis }\end{array}$ & RosOvlPo & $\mathrm{x}$ & $\mathrm{x}$ & 7 & $\mathrm{x}$ & $\mathrm{x}$ & 16 \\
\hline 107 & Rostrozetes sp 1 & RostrSpl & $\mathrm{x}$ & - & 2 & $\mathrm{x}$ & $\mathrm{x}$ & 3 \\
\hline 108 & Rostrozetes sp 3 & RostrSp3 & $\mathrm{x}$ & - & 1 & $\mathrm{x}$ & $\mathrm{x}$ & 6 \\
\hline 109 & Rostrozetes sp 4 & RostrSp4 & $\mathrm{x}$ & $\mathrm{x}$ & 5 & $\mathrm{x}$ & $\mathrm{x}$ & 6 \\
\hline 110 & Rostrozetes sp 5 & RostrSp5 & $\mathrm{x}$ & - & 2 & $\mathrm{x}$ & $\mathrm{x}$ & 6 \\
\hline 111 & Rostrozetes sp 6 & RostrSp6 & $\mathrm{x}$ & $\mathrm{x}$ & 21 & $\mathrm{x}$ & $\mathrm{x}$ & 16 \\
\hline 112 & $\begin{array}{l}\text { Scapheremaeus } \\
\text { bicornutus }\end{array}$ & & - & - & 0 & $\mathrm{x}$ & - & 1 \\
\hline 113 & $\begin{array}{l}\text { Scapheremaeus } \\
\text { fungisetosus }\end{array}$ & & $\mathrm{x}$ & - & 2 & - & - & 0 \\
\hline 114 & Schalleria brevisetosa & SchlBrev & - & - & 0 & $\mathrm{x}$ & $\mathrm{x}$ & 5 \\
\hline 115 & Schalleria pectinata & SchlPect & - & - & 0 & $\mathrm{x}$ & $\mathrm{x}$ & 22 \\
\hline 116 & Scheloribates laticlava & SchlLatc & $\mathrm{x}$ & - & 1 & $\mathrm{x}$ & $\mathrm{x}$ & 3 \\
\hline 117 & Scheloribates artigasi & & - & - & 0 & $\mathrm{x}$ & - & 1 \\
\hline 118 & $\begin{array}{l}\text { Scheloribates } \\
\text { diversidactylus }\end{array}$ & & $\mathrm{x}$ & - & 1 & - & - & 0 \\
\hline 119 & Scheloribates elegans & & $\mathrm{x}$ & - & 1 & - & - & 0 \\
\hline 120 & $\begin{array}{l}\text { Scheloribates } \\
\text { huancayensis } s p\end{array}$ & & - & - & 0 & $\mathrm{x}$ & - & 1 \\
\hline 121 & Scheloribates $n$ sp 1 & & $\mathrm{x}$ & - & 1 & $\mathrm{x}$ & - & 1 \\
\hline 122 & Scheloribates n sp 1.1 & & - & - & 0 & $\mathrm{x}$ & - & 1 \\
\hline 123 & $\begin{array}{l}\text { Sellnickochthonius } \\
\text { elsosneadensis sp }\end{array}$ & SellElso & $\mathrm{x}$ & $\mathrm{x}$ & 11 & - & - & 0 \\
\hline 124 & $\begin{array}{l}\text { Sellnickochthonius } \\
\text { muara sp }\end{array}$ & SellMuar & - & - & 0 & $\mathrm{x}$ & $\mathrm{x}$ & 5 \\
\hline 125 & Sellnickochthonius tropic & & $\mathrm{x}$ & - & 2 & - & - & 0 \\
\hline 126 & Solenozetes carinatus & SolnCarn & $\mathrm{x}$ & $\mathrm{x}$ & 6 & $\mathrm{x}$ & $\mathrm{x}$ & 39 \\
\hline 127 & Solenozetes flagellatus & SolnFlag & $\mathrm{x}$ & $\mathrm{x}$ & 4 & $\mathrm{x}$ & $\mathrm{x}$ & 9 \\
\hline 128 & Solenozetes $n$ sp 1 & SolenSp1 & - & - & 0 & $\mathrm{x}$ & $\mathrm{x}$ & 52 \\
\hline
\end{tabular}




\begin{tabular}{|c|c|c|c|c|c|c|c|c|}
\hline No. & Species & Abbreviation & Leaves & $\begin{array}{c}\text { Included } \\
\text { in CCA } \\
\text { leaves }\end{array}$ & $\begin{array}{l}\text { Abundance } \\
\text { in leaves }\end{array}$ & Roots & $\begin{array}{c}\text { Included } \\
\text { in CCA } \\
\text { roots }\end{array}$ & $\begin{array}{l}\text { Abundance } \\
\text { in roots }\end{array}$ \\
\hline 129 & Sternoppia brasiliensis & SterBras & $\mathrm{x}$ & - & 2 & $\mathrm{x}$ & $\mathrm{x}$ & 3 \\
\hline 130 & Sternoppia fissurata & SterFiss & - & - & 0 & $\mathrm{x}$ & $\mathrm{x}$ & 14 \\
\hline 131 & Sternoppia incisa & SterIncs & $\mathrm{x}$ & - & 1 & $\mathrm{x}$ & $\mathrm{x}$ & 10 \\
\hline 132 & Sternoppia mirabilis & SterMirb & $\mathrm{x}$ & $\mathrm{x}$ & 5 & - & - & 0 \\
\hline 133 & Sternoppia $n$ sp 1 & & - & - & 0 & $\mathrm{x}$ & - & 1 \\
\hline 134 & Sternoppia $n$ sp 3 & SternSp3 & - & - & 0 & $\mathrm{x}$ & $\mathrm{x}$ & 5 \\
\hline 135 & Sternoppia $n$ sp 6 & SternSp6 & - & - & 0 & $\mathrm{x}$ & $\mathrm{x}$ & 4 \\
\hline 136 & Sternoppia $n$ sp 8 & & - & - & 0 & $\mathrm{x}$ & - & 1 \\
\hline 137 & Sternoppia paraincisa & SterPara & $\mathrm{x}$ & - & 1 & $\mathrm{x}$ & $\mathrm{x}$ & 22 \\
\hline 138 & Sternoppia paramirabilis & SterParm & - & - & 0 & $\mathrm{x}$ & $\mathrm{x}$ & 5 \\
\hline 139 & Striatoppia opuntiseta & & - & - & 0 & $\mathrm{x}$ & - & 1 \\
\hline 140 & Striatoppia silvicola & & - & - & 0 & $\mathrm{x}$ & - & 1 \\
\hline 141 & Suctobelba compacta & & $\mathrm{x}$ & - & 1 & - & - & 0 \\
\hline 142 & Suctobelbella andrassyi & & - & - & 0 & $\mathrm{x}$ & - & 1 \\
\hline 143 & Suctobelbella baculifera & & - & - & 0 & $\mathrm{x}$ & - & 1 \\
\hline 144 & Suctobelbella claviseta & SuctClav & $\mathrm{x}$ & $\mathrm{x}$ & 7 & $\mathrm{x}$ & $\mathrm{x}$ & 19 \\
\hline 145 & Suctobelbella complexa & SuctComp & $\mathrm{x}$ & $\mathrm{x}$ & 16 & $\mathrm{x}$ & $\mathrm{x}$ & 4 \\
\hline 146 & $\begin{array}{l}\text { Suctobelbella complexa } \\
\text { sp Form } 2\end{array}$ & SucComF2 & $\mathrm{x}$ & $\mathrm{x}$ & 14 & $\mathrm{x}$ & $\mathrm{x}$ & 34 \\
\hline 147 & Suctobelbella loksai & SuctLoks & $\mathrm{x}$ & - & 1 & $\mathrm{x}$ & $\mathrm{x}$ & 4 \\
\hline 148 & $\begin{array}{l}\text { Suctobelbella } \\
\text { macrodentata }\end{array}$ & & $\mathrm{x}$ & - & 1 & $\mathrm{x}$ & - & 2 \\
\hline 149 & Suctobelbella $n s p 1$ & & - & - & 0 & $\mathrm{x}$ & - & 1 \\
\hline 150 & Suctobelbella $n$ sp 3 & SuctbSp3 & - & - & 0 & $\mathrm{x}$ & $\mathrm{x}$ & 3 \\
\hline 151 & Suctobelbella peracuta & SuctPerc & $\mathrm{x}$ & - & 1 & $\mathrm{x}$ & $\mathrm{x}$ & 4 \\
\hline 152 & Suctobelbella perdentata & & $\mathrm{x}$ & - & 2 & $\mathrm{x}$ & - & 1 \\
\hline 153 & $\begin{array}{l}\text { Suctobelbella } \\
\text { semiplumosa indica }\end{array}$ & SucSemIn & $\mathrm{x}$ & $\mathrm{x}$ & 5 & $\mathrm{x}$ & - & 2 \\
\hline 154 & $\begin{array}{l}\text { Suctobelbella } \\
\text { semiplumosa sp Form1 }\end{array}$ & SucSemF1 & $\mathrm{x}$ & $\mathrm{x}$ & 13 & $\mathrm{x}$ & $\mathrm{x}$ & 15 \\
\hline 155 & $\begin{array}{l}\text { Suctobelbella } \\
\text { variosetosa }\end{array}$ & & $\mathrm{x}$ & - & 2 & - & - & 0 \\
\hline 156 & Suctobelbila $n$ sp 1 & & - & - & 0 & $\mathrm{x}$ & - & 1 \\
\hline 157 & Suctobelbila $n$ sp 2 & & $\mathrm{x}$ & - & 1 & $\mathrm{x}$ & - & 1 \\
\hline 158 & Suctobelbila n sp 3 & SuctbSp3 & - & - & 0 & $\mathrm{x}$ & - & 2 \\
\hline 159 & Suctobelbila $n$ sp 5 & & - & - & 0 & $\mathrm{x}$ & - & 1 \\
\hline 160 & Suctobelbila peruensis & SuctPeru & $\mathrm{x}$ & $\mathrm{x}$ & 7 & $\mathrm{x}$ & - & 2 \\
\hline 161 & Suctoribates $n$ sp 1 & SuctrSpl & $\mathrm{x}$ & $\mathrm{x}$ & 4 & $\mathrm{x}$ & $\mathrm{x}$ & 4 \\
\hline 162 & Suctoribates Oxyamerus & & $\mathrm{x}$ & - & 1 & - & - & 0 \\
\hline
\end{tabular}




\begin{tabular}{|c|c|c|c|c|c|c|c|c|}
\hline No. & Species & Abbreviation & Leaves & $\begin{array}{c}\text { Included } \\
\text { in CCA } \\
\text { leaves }\end{array}$ & $\begin{array}{l}\text { Abundance } \\
\text { in leaves }\end{array}$ & Roots & $\begin{array}{c}\text { Included } \\
\text { in } \mathrm{CCA} \\
\text { roots }\end{array}$ & $\begin{array}{l}\text { Abundance } \\
\text { in roots }\end{array}$ \\
\hline 163 & Tecteremaeus cornutus & TectCorn & $\mathrm{x}$ & - & 2 & $\mathrm{x}$ & $\mathrm{x}$ & 23 \\
\hline 164 & $\begin{array}{l}\text { Tecteremaeus } \\
\text { incompletus }\end{array}$ & TectIncm & $\mathrm{x}$ & $\mathrm{x}$ & 4 & $\mathrm{x}$ & $\mathrm{x}$ & 13 \\
\hline 165 & Tectocepheus minor & TectMinr & $\mathrm{x}$ & $\mathrm{x}$ & 5 & $\mathrm{x}$ & - & 1 \\
\hline 166 & $\begin{array}{l}\text { Tectocepheus velatus } \\
\text { sarekensis }\end{array}$ & TecVelSr & $\mathrm{x}$ & $\mathrm{x}$ & 3 & - & - & 0 \\
\hline 167 & $\begin{array}{l}\text { Tectocepheus velatus } \\
\text { velatus }\end{array}$ & TecVelVl & $\mathrm{x}$ & $\mathrm{x}$ & 3 & - & - & 0 \\
\hline 168 & $\begin{array}{l}\text { Tegeocranellus } \\
\text { bolivianus }\end{array}$ & TegeBolv & $\mathrm{x}$ & $\mathrm{x}$ & 14 & $\mathrm{x}$ & $\mathrm{x}$ & 3 \\
\hline 169 & Teratoppia $n$ sp 1 & TeratSp1 & $\mathrm{x}$ & $\mathrm{x}$ & 3 & $\mathrm{x}$ & $\mathrm{x}$ & 5 \\
\hline 170 & $\begin{array}{l}\text { Teratoppia } \\
\text { pluripectinata }\end{array}$ & TertPlur & $\mathrm{x}$ & $\mathrm{x}$ & 17 & $\mathrm{x}$ & $\mathrm{x}$ & 16 \\
\hline 171 & Xenillus $n$ sp 2 & & - & - & 0 & $\mathrm{x}$ & - & 1 \\
\hline 172 & Xenillus setiger & & - & - & 0 & $\mathrm{x}$ & - & 1 \\
\hline 173 & Xenolohmannia comosa & XenlComs & $\mathrm{x}$ & - & 1 & $\mathrm{x}$ & $\mathrm{x}$ & 3 \\
\hline 174 & Yoshiobodes $n$ sp 1 & & - & - & 0 & $\mathrm{x}$ & - & 1 \\
\hline 175 & Yoshiobodes $n$ sp 2 & & - & - & 0 & $\mathrm{x}$ & - & 1 \\
\hline 176 & Zetomimus polpaicoensis & & $\mathrm{x}$ & - & 1 & - & - & 0 \\
\hline
\end{tabular}


Appendix 6. Mahalanobis Distances $\left(\mathrm{MD}^{2}\right)$ of discriminant function analysis (DFA) based on Oribatida community composition in leaf and root litter exposed at 1000, 2000 and 3000 $\mathrm{m}$ for 12 months.

\begin{tabular}{c|c|c|c|c|c|c}
\hline Litter type & From & F-value & df1 & df2 & p-value & MD $^{2}$ \\
\hline \hline \multirow{5}{*}{ Leaf } & $1000 \mathrm{~m}-2000 \mathrm{~m}$ & 63.45 & 2 & 28 & $<0.001$ & 3.76 \\
& $1000 \mathrm{~m}-3000 \mathrm{~m}$ & 45.10 & 2 & 23 & $<0.001$ & 4.85 \\
& $2000 \mathrm{~m}-3000 \mathrm{~m}$ & 23.27 & 2 & 24 & $<0.001$ & 3.80 \\
\hline \multirow{5}{*}{ Root } & $1000 \mathrm{~m}-2000 \mathrm{~m}$ & 74.21 & 2 & 32 & $<0.001$ & 4.14 \\
& $1000 \mathrm{~m}-3000 \mathrm{~m}$ & 53.69 & 2 & 30 & $<0.001$ & 3.99 \\
& $2000 \mathrm{~m}-3000 \mathrm{~m}$ & 23.62 & 2 & 29 & $<0.001$ & 3.43 \\
\hline
\end{tabular}


Chapter 4

Impacts of core rotation, defaunation and nitrogen addition on arbuscular mycorrhizal fungi, microorganisms and microarthropods in a tropical montane rainforest

Laura M. Sánchez Galindo, Tessa Camenzind, Mark Maraun \& Stefan Scheu
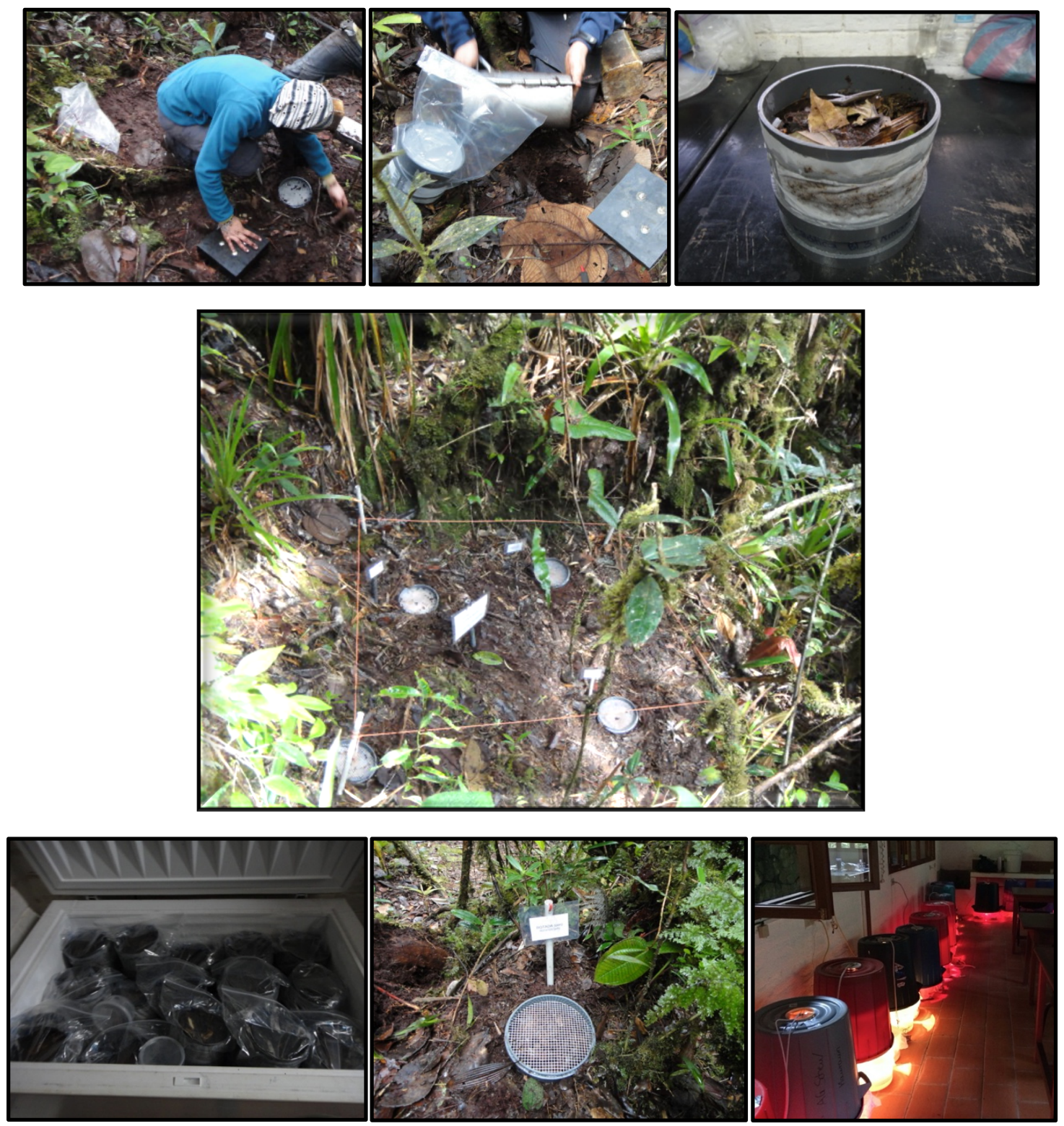


\section{Abstract}

In tropical ecosystems interactions between arbuscular mycorrhizal fungi (AMF) and other organisms have been little studied, but may be of significant importance for understanding the role of AMF in decomposition processes and nutrient cycling. In this study, we used ingrowth cores to investigate the impacts of regular rotation of the cores, defaunation and nitrogen addition on AMF, microbial biomass and microarthropods in the fermentation/humus $(\mathrm{F} / \mathrm{H})$ and litter $(\mathrm{L})$ layers of an Ecuadorian montane tropical rainforest. AMF were substantially reduced in the $\mathrm{F} / \mathrm{H}$ layer (to $34 \%$ of initial), while in the L layer they remained constant during the experiment. Overall, microorganisms and microarthropods were largely independent of AMF hyphae and their exudates, however, defaunation strongly affected the recovery of their communities. Nitrogen addition increased the quality of litter material and beneficially affected microbial communities thereby increasing decomposition rates, but did not impact AMF abundance and microarthropod communities. These findings suggest that the cutoff of the carbon supply from the plant to the fungal mycelium was not compensated by switching resources in the $\mathrm{F} / \mathrm{H}$ layer, underlining strong association of AMF and living roots. While in the L layer, AMF likely competed with saprotrophic microorganisms for litter-derived resources at intermediate stages of decomposition pointing to indirect contributions of AMF to decomposition processes. Overall, the results support the view that root-derived resources are important in fueling soil food webs, but also indicate that in the studied montane rainforest these resources are only available close to roots and not channeled distant to roots via AMF.

Keywords: Acari, Collembola, Organic layer, Oribatid mites, Root-derived resources, Saprotrophic fungi. 


\section{Introduction}

Mycorrhizal fungi are key components of microorganisms in soil influencing plant nutrient uptake and growth (Johansson et al. 2004; Brundrett and Tedersoo 2018). In tropical forest ecosystems, arbuscular mycorrhiza fungi (AMF; Glomeromycotina) represent the dominant mycorrhizal form (Kottke et al. 2004; Öpik et al. 2006). These obligate biotrophs facilitate the mobilization and uptake of mineral by plants released from decomposition of organic matter in exchange for photosynthetic carbon (Read and Perez-Moreno 2003; Smith and Read 2008; Johnson 2010; Bagyaraj 2014). Factors that affect the abundance and effectiveness of AMF include climatic changes, soil fertility, disturbances and changes in nutrient availability (Gryndler 2000; Cardoso and Kuyper 2006; Camenzind et al. 2014; Lehmann et al. 2017). Elevated nutrient availability - mainly $\mathrm{P}$ and $\mathrm{N}$ - decreases the formation of fine roots and mycorrhizal structures, reducing the benefit provided by these symbionts (Treseder and Allen 2002; Johnson 2010). Therefore, changes following nutrient additions might strongly affect tropical forests where $\mathrm{P}$ and $\mathrm{N}$ are limiting and plants rely on AMF symbionts (Cardoso and Kuyper 2006; Dalling et al. 2016; Sheldrake et al. 2018).

In addition to roots, AMF interact with other organisms including bacteria, saprotrophic fungi, protozoa, nematodes, arthropods and even large animals (Ruess and Lussenhop 2005; Miransari 2011; Lehmann et al. 2017). These interactions may be synergistic, competitive or antagonistic and may affect all stages of the mycorrhizal fungal life cycle (Finlay 2004; Johansson et al. 2004; Miransari 2011). Interacting mechanisms which are of particular importance for the functioning of the symbiosis include mycorrhiza associated bacteria promoting or inhibiting mycorrhiza formation (Toljander et al. 2007; Svenningsen et al. 2018), potential restriction of saprotrophic fungal activity due to competition for substrate (Bödeker et al. 2016; Marian et al. 2019), and grazing of external mycelium by soil microarthropods (Ruess and Lussenhop 2005; A'Bear et al. 2014). The most abundant and frequent groups of soil microarthropods are mites (Acari) and springtails (Collembola) (Maraun et al. 2003; Franklin et al. 2004). Particularly oribatid mites (Oribatida) are rich in species and colonize virtually any soil reaching maximum diversity and density in forest ecosystems, where they participate in the decomposition of organic matter (Franklin et al. 2004). Oribatid mites feed on a variety of fungal species and contribute to the dispersion of 
fungal structures (Renker et al. 2005; Vašutová et al. 2019). However, AMF presumably are not the preferred food resource of oribatid mites, but might be consumed to some extent (Gange and Brown 2002; Schneider et al. 2005).

Typically, interactions between soil microarthropods and AMF are studied using sterilized soil re-inoculated with microorganisms and microarthropods (Toljander et al. 2007; Nuccio et al. 2013; Ngosong et al. 2014). For quantifying AMF biomass, as well as their contribution to nutrient translocation, plant growth and their interactions with microbial communities, ingrowth cores are increasingly used (Nottingham et al. 2013; Leifheit et al. 2014). Ingrowth cores comprise compartments separated by mesh barriers for excluding roots, but allowing access of extraradical mycorrhizal hyphae, with soil physical and chemical conditions inside the cores resembling those outside the cores (Wallander et al. 2013). Rotating these cores detaches fungal ingrowth and thereby, the comparison of rotated and non-rotated cores provides insight into the role of mycorrhizal fungi for element cycling and decomposition (Johnson et al. 2001).

To explore the role of AMF in soil nutrient dynamics and their interactions with soil organisms in tropical montane rainforests, we evaluated the impact of rotation of ingrowth cores in combination with soil defaunation and $\mathrm{N}$ addition on AMF abundance, microorganisms and soil microarthropods, with focus on oribatid mites. We hypothesized that (1) the colonization of soil inside the cores by AMF is reduced by regular rotation. Assuming that mycorrhiza indirectly alter decomposition processes by restraining the activity of saprotrophic fungi we furthermore hypothesized that (2) the exclusion of mycorrhiza results in increased activity of saprotrophic microorganisms, accelerating decomposition processes. Further, we hypothesized that (3) oribatid mites benefit from the increased dominance of saprotrophic fungi in rotated cores. Also, we hypothesized that (4) the reduction of microarthropod abundance in defaunated cores promotes fast recovery of AMF mycelium and soil microorganisms. Finally, we hypothesized that (5) the addition of $\mathrm{N}$ reduces the concentration of AMF, but fosters the activity of saprotrophic microorganisms and thereby increases litter decomposition. 


\section{Material and methods}

\section{Study site}

The study site is located in Southern Ecuador within the Podocarpus National Park near the research station San Francisco at $2000 \mathrm{~m}$ a.s.1. $\left(3^{\circ} 58^{\prime} \mathrm{S}, 7^{\circ} 04^{\prime} \mathrm{W}\right)$ (for location details see Richter et al. 2009). The climate is warm humid with an average annual temperature of $15.2^{\circ} \mathrm{C}$ and an annual precipitation of approximately $2000 \mathrm{~mm}$. Precipitation is high from April to September, and lower between October and March, but there is no pronounced dry season (Bendix et al. 2006). The soil is stagnic cambisol with a thick organic layer ranging between 8 and $40 \mathrm{~cm}$ (Wilcke et al. 2002; Wullaert et al. 2010). The area is characterized by high diversity of organisms and a particular high number of endemic vascular plant species, with Melastomataceae, Lauraceae and Rubiaceae being the dominant plant families (Bendix et al. 2006; Beck and Ritcher 2008; Homeier et al. 2010). Roots of trees in the forests are colonized predominantly by AMF and are characterized by high rates of AMF colonization suggesting high contribution of AMF hyphae to soil fungal biomass (Kottke et al. 2004; Camenzind and Rillig 2013).

\section{Ingrowth core}

Ingrowth cores were constructed using $15 \mathrm{~cm}$ (diameter) x $20 \mathrm{~cm}$ (length) plastic tubes. Two rectangular holes $(10 \times 15 \mathrm{~cm})$ opposite to each other were cut into the tubes and covered with $45 \mu \mathrm{m}$ nylon mesh. Two layers of $45 \mu \mathrm{m}$ nylon mesh, separated by $5 \mathrm{~cm}$, were glued inside the tubes to allow drainage of leaching water but block ingrowth of roots and mycorrhizal hyphae from the bottom. The ingrowth cores were closed with a lid of 4 $\mathrm{mm}$ nylon mesh to allow mesofauna access (Figure 1A). 
A.

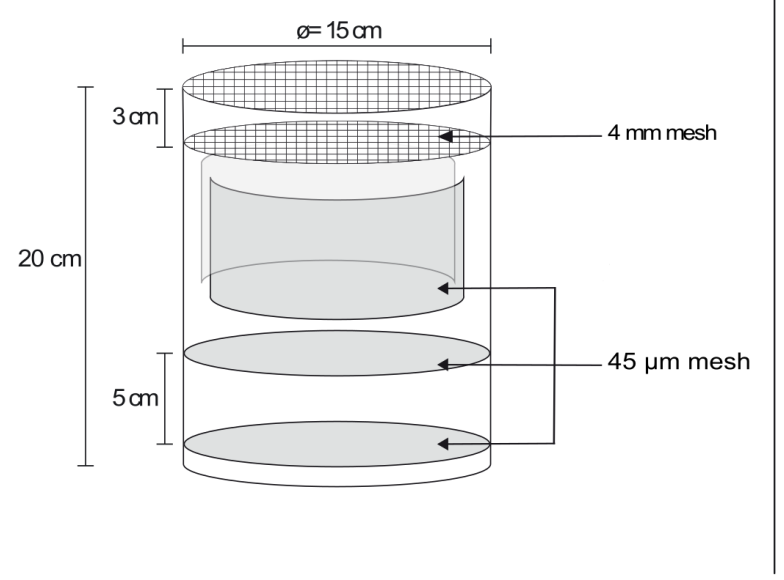

B.

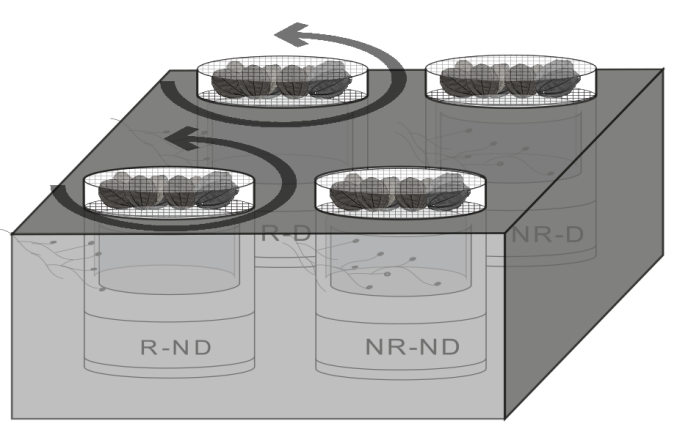

Figure 1. Scheme of the ingrowth cores and representation of experimental design. (A) Scheme of the ingrowth cores; see text for details. (B). Representation of the experimental design per subplot with the ingrowth cores inserted in the soil and litter material placed on top of the soil inside the cores separated from the soil by $4 \mathrm{~mm}$ mesh; four ingrowth cores were placed per subplot; R-ND= rotated and non-defaunated, $\mathrm{R}-\mathrm{D}=$ rotated and defaunated, NR-ND $=$ non-rotated and nondefaunated, NR-D = non-rotated and defaunated; arrows indicate rotation by $45^{\circ}$ every second day.

\section{Experimental design}

The experiment started in June 2015 and was conducted in the framework of the Nutrient Manipulation Experiment (NUMEX) (Homeier et al. 2012). Briefly, NUMEX is an altitudinal fertilization experiment that was set up in a complete randomized block design with four blocks, each containing one plot $(20 \times 20 \mathrm{~m})$ of four different treatments: addition of $\mathrm{N}(+\mathrm{N})$, addition of $\mathrm{P}(+\mathrm{P})$, addition of $\mathrm{N}$ and $\mathrm{P}(+\mathrm{N}+\mathrm{P})$ and unfertilized control plots (Ctr) (Wullaert et al. 2010; Homeier et al. 2012). For the present experiment soil samples ( $\sim 15 \mathrm{~cm}$ deep) were taken from two subplots $(2 \times 2 \mathrm{~m})$ marked randomly inside the $+\mathrm{N}$ and Ctr plots of NUMEX at $2000 \mathrm{~m}$ with a stainless-steel corer (14.5 cm inner diameter). The soil samples comprised the fermentation/humus $(\mathrm{F} / \mathrm{H})$ and litter $(\mathrm{L})$ layers and were inserted intact into the ingrowth cores and placed into the same holes from which the soil sample were excavated. Prior to placement in the field, half of the prospective rotated and non-rotated cores were frozen at $-20^{\circ} \mathrm{C}$ for one week to kill soil living animals. Once in the field, the soil sample was covered by $4 \mathrm{~mm}$ mesh on top of which $2 \mathrm{~g}$ of dry $\left(60^{\circ} \mathrm{C}, 48 \mathrm{~h}\right)$ Graffenrieda emarginata leaves, the most abundant tree species in the study area, were placed as standard litter material allowing to investigate the decomposition of leaf litter 
inside the cores (Figure 1B). Decomposition of the added Graffenrieda litter was calculated as mass loss $(\%)=\left(\left(m_{0}-m_{1} / m_{0}\right)\right) \times 100$, with $m_{0}$ as the initial dry weight of the leaves and $\mathrm{m}_{1}$ as the dry weight of the leaves at harvest.

The cores were rotated every second day by $45^{\circ}$ during 5 months. After removal of the cores by the end of the experiment, $\mathrm{L}$ and $\mathrm{F} / \mathrm{H}$ layer materials were sampled separately. Half of each sample was used for the analysis of soil properties, the other half for extraction of microarthropods. Microarthropods were extracted by heat using a modified high gradient extractor (Macfadyen 1961; Kempson et al. 1963). Thereafter, they were determined to group level (Oribatida, Collembola, Prostigmata, Gamasina, Uropodina), with the exception of adult Oribatida which were identified to species level. For identification, the keys of Hammer $(1958,1961)$ and Balogh and Balogh $(1990,2002)$ were used and nomenclature followed Subías (2018).

\section{Microbial respiration and microbial biomass}

Microbial basal respiration (BR) and microbial biomass $\left(\mathrm{C}_{\text {mic }}\right)$ were determined by measuring $\mathrm{O}_{2}$ consumption using an automated respirometer system (Scheu 1992). The $\mathrm{O}_{2}$ consumption was measured every hour during $24 \mathrm{~h}$ at $22^{\circ} \mathrm{C}$. BR $\left(\mu 1 \mathrm{O}_{2} \mathrm{~g}^{-1}\right.$ dry weight $\left.\mathrm{h}^{-1}\right)$ was calculated as mean of $\mathrm{O}_{2}$ consumption rates from 10 to $20 \mathrm{~h}$ after attachment of the samples to the respirometer system.

$\mathrm{C}_{\text {mic }}$ ( $\mu \mathrm{g} \mathrm{g}^{-1}$ dry weight) was determined by measuring the maximum initial respiratory response (MIRR; $\mu 1 \mathrm{O}_{2} \mathrm{~g}^{-1} \mathrm{~h}^{-1}$ ). Moist samples equivalent to $0.2 \mathrm{~g}$ dry weight were supplemented with D-glucose $\left(80 \mathrm{mg} \mathrm{g}^{-1}\right.$ and $40 \mathrm{mg} \mathrm{g}^{-1}$ dry weight for $\mathrm{L}$ and $\mathrm{F} / \mathrm{H}$ layers, respectively). The average of the lowest three readings within the first $10 \mathrm{~h}$ was used as MIRR. Microbial biomass was calculated as $\mathrm{C}_{\text {mic }}=38 \times$ MIRR (SIR-method;Anderson and Domsch 1978; Beck et al. 1997). 


\section{Fatty acid analysis}

Phospholipid fatty acids (PLFAs) and neutral lipid fatty acids (NFLAs) were extracted from $\mathrm{L}$ and $\mathrm{F} / \mathrm{H}$ layer material, as well as from initial soil samples taken from each subplot following the protocol of Frostegård et al. (1993). Fatty acid methyl esters (FAMEs) were identified by chromatographic retention time based on a standard mixture composed of 37 different FAMEs ranging from C11 to C24 (Sigma-Aldrich, St Louis, USA). The analysis was performed by gas chromatography using a GC-FID Clarus 500 (PerkinElmer Corporation, Norwalk, USA) equipped with HP-5 capillary column (30 m x $0.32 \mathrm{~mm}$ id, film thickness $0.25 \mu \mathrm{m}$ ).

PLFAs and NLFAs were expressed in $\mathrm{nmol} \mathrm{g}^{-1}$ dry weight. PLFAs were used as indicator of the microbial community structure. The sum of i15:0, a15:0, 15:0, i16:0, 16:1w7, i17:0, 17:0, cy 17:0, 18:1 $\omega 7$ and cy 19:0 was used as indicator of bacterial biomass (Frostegård et

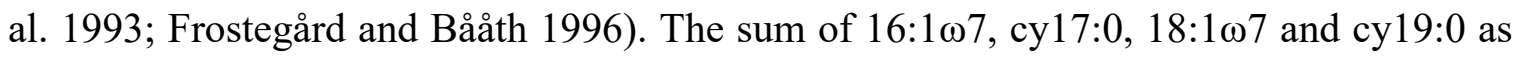
indicator of Gram-negative and the sum of i15:0, a15:0, i16:0, i17:0 and a17:0 as indicator

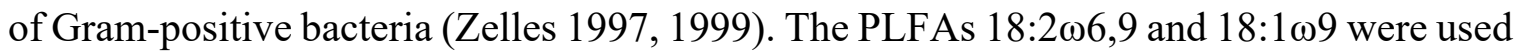
as markers for saprotrophic fungi (Frostegård and Bååth 1996; Ruess and Chamberlain 2010). The NLFA 16:1 15 was used as marker for AMF (Olsson et al. 1995; Olsson 1999).

\section{Carbon and nitrogen analyses}

Soil $\mathrm{pH}$ was determined based on a 1:5 (v:v) suspension of soil in deionized water. Total C and $\mathrm{N}$ contents in soil and litter were determined from milled samples using an elemental analyzer (EuroEA, HekaTech, Germany). The fraction of Bray-extractable inorganic phosphorus $(\mathrm{P})$ in soil was determined based on protocols described by Bray and Kurtz (1945). Available P was extracted from $2 \mathrm{~g}$ dry soil adding a solution containing hydrochloric acid $(\mathrm{HCl})$ and ammonium fluoride $\left(\mathrm{NH}_{4} \mathrm{~F}\right)$. The resulting $\mathrm{P}$ content in the solution filtered through phosphorus-free filter paper was analyzed by ICP-OES analyses (Optima 2100 DV, Perkin Elmer, Germany). 


\section{Statistical analyses}

Prior to statistical analysis, the data were inspected for normality and homogeneity of variance using Shaphiro wilks and Breush-Pagan test, respectively. If necessary, data were log- or arcsine-transformed to improve homogeneity of variances. Soil characteristics (concentration of $\mathrm{C}, \mathrm{N}, \mathrm{PO}_{4}{ }^{3-}, \mathrm{P}$ and $\mathrm{pH}$ ), microbial activity (BR and $\mathrm{C}_{\mathrm{mic}}$ ), fatty acids (NLFAs and PLFAs) and microarthropod groups (Oribatida, Gamasina, Uropodina, Astigmata and Prostigmata (all Acari) and Collembola) were analyzed using separated three-way linear mixed-effects models (LMM) with rotation, $\mathrm{N}$ addition and defaunation fitted as fixed effects and block fitted as random effect. Oribatid mite community data were compressed using non-metric multidimensional scaling (NMDS). Only species with more than three individuals in the samples were included. The stress value obtained reduced the number of meaningful dimensions to six axes. Afterwards, multivariate analysis of variance (MANOVA) was used to inspect effects of treatments on oribatid mite community composition. Additionally, using the same data set principal components analysis (PCA) was used to analyze and present graphically the response of oribatid mite species to rotation, $\mathrm{N}$ addition and defaunation in the $\mathrm{L}$ and $\mathrm{F} / \mathrm{H}$ layer. The soil layer ( $\mathrm{L}$ and $\mathrm{F} / \mathrm{H}$ layer) and the three treatments (Rotation, $\mathrm{N}$ addition and defaunation) were coded as supplementary variables not affecting the ordination. Only species that were present in more than three samples were included in the analysis. PCA was carried out using CANOCO 5 (Ter Braak and Smilauer 2012). LMM, MANOVA and NMDS were conducted in $\mathrm{R}$ version 3.2.1 (R Core Team 2014) using the functions lme() in the package "nlme", manova() in the package "stats" and metaMDS() in the package "vegan", respectively.

\section{Results}

\section{Litter decomposition}

On average, $70 \%$ of the initial dry mass of the leaf litter placed in the upper part of the cores remained at the end of the experiment. Rotation and defaunation did not significantly 
affect litter decomposition, however, the leaves decomposed faster in the cores of the $+\mathrm{N}$ than in those of the $\mathrm{Ctr}$ treatment ( $31.8 \%$ vs. $\left.26.9 \%, \mathrm{~F}_{1,57}=6.69, \mathrm{p}=0.01\right)$.

In general, the $\mathrm{C} / \mathrm{N}$ ratio was higher in the cores of the $\mathrm{Ctr}$ than in those of the $+\mathrm{N}$ treatment with averages of $38.33 \pm 0.22 v s .33 .74 \pm 0.23\left(\mathrm{~F}_{1,57}=8.22, \mathrm{p}=0.005\right)$ for the $\mathrm{L}$ layer and $27.67 \pm 0.26$ vs. $25.39 \pm 0.25\left(\mathrm{~F}_{1,57}=4.16, \mathrm{p}=0.04\right)$ for the $\mathrm{F} / \mathrm{H}$ layer. Further, the $\mathrm{C} / \mathrm{N}$ ratio of the $\mathrm{L}$ layer in defaunated cores exceeded that of the $\mathrm{F} / \mathrm{H}$ layer with an average of $38.38 \pm 0.29$ vs. $33.69 \pm 0.18\left(\mathrm{~F}_{1,57}=7.22, \mathrm{p}=0.009\right)$. Rotation of the cores did not significantly affect the $\mathrm{C} / \mathrm{N}$ ratio of the $\mathrm{L}$ and $\mathrm{F} / \mathrm{H}$ layer.

Concentrations of $\mathrm{PO}_{4}{ }^{3-}$ and available $\mathrm{P}$ (only measured in the $\mathrm{F} / \mathrm{H}$ layer) did not differ significantly between treatments with averages of $0.21 \pm 0.09$ and $0.06 \pm 0.02 \mathrm{mg} \mathrm{g}^{-1}$, respectively. However, the $\mathrm{pH}$ (only measured in $\mathrm{F} / \mathrm{H}$ layer) in the $+\mathrm{N}$ treatment exceeded that in the Ctr treatment (3.94 vs. 3.79; $\left.\mathrm{F}_{1,57}=7.62, \mathrm{p}=0.007\right)$.

\section{Arbuscular mycorrhizal fungi}

Generally, the concentration of NLFA 16:105 in the F/H layer declined during the experiment from an overall mean of $33.38 \pm 10.83$ to $21.83 \pm 5.11 \mathrm{nmol} \mathrm{g}^{-1}$ by the end of the experiment $\left(\mathrm{F}_{1,22}=12.39, \mathrm{p}=0.001\right.$; Figure $\left.2 \mathrm{~A}\right)$. By contrast, it stayed at the same level in the L layer (overall mean $16.08 \pm 6.10 \mathrm{nmol} \mathrm{g}^{-1}$ ). Defaunation significantly reduced the concentration of NLFA 16:1 105 in the F/H layer $\left(F_{1,56}=10.44, p=0.002\right.$; Figure $\left.2 B\right)$ but not in the L layer. Neither rotation nor $\mathrm{N}$ addition affected the concentrations of NLFA $16: 1 \omega 5$ in the $\mathrm{L}$ and $\mathrm{F} / \mathrm{H}$ layer. 

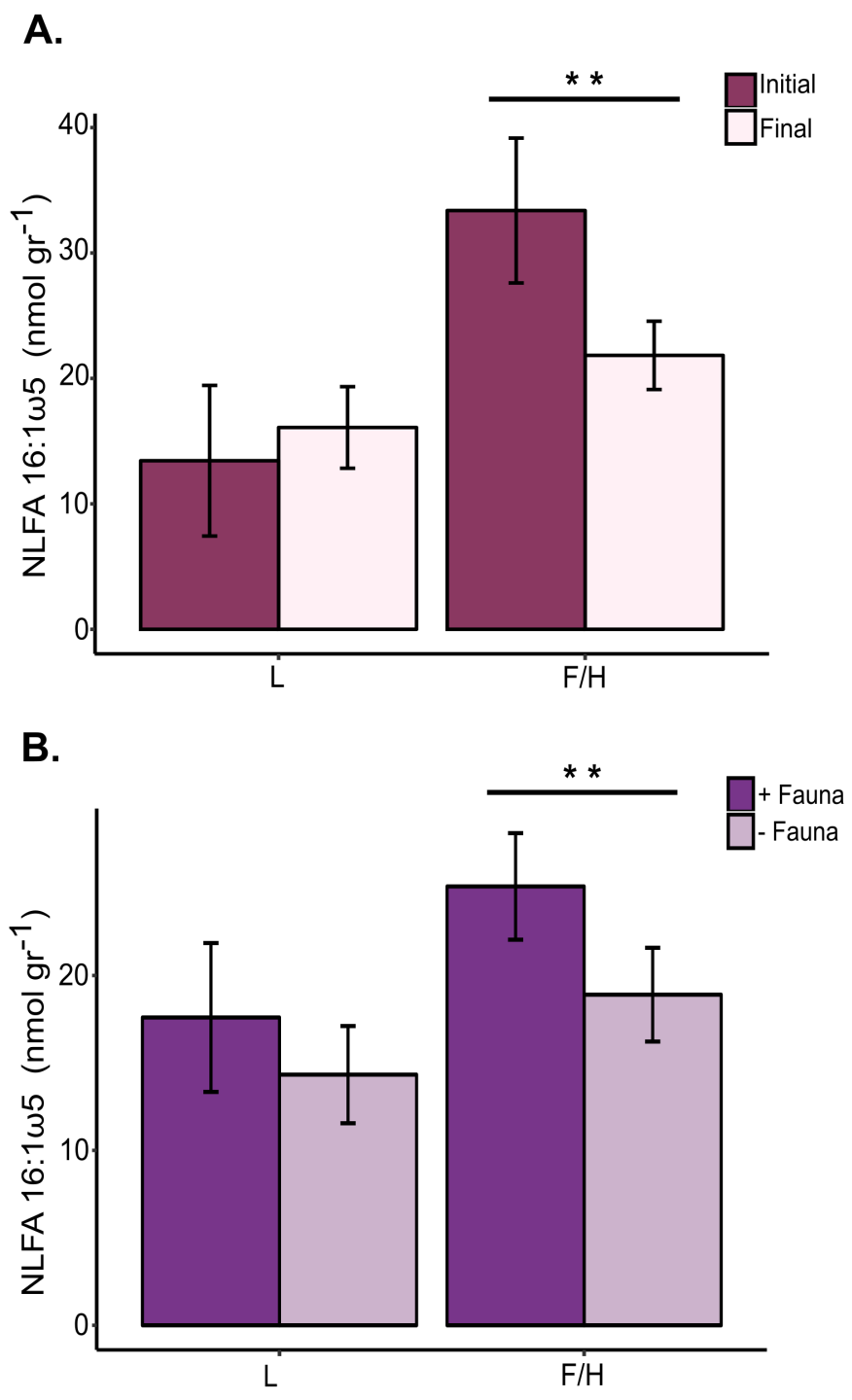

Figure 2. Concentration of the AMF marker fatty acid in the $L$ and $F / H$ layer. Variations in the concentration of the AMF marker fatty acid 16:1 $\omega 5$ in the $\mathrm{L}$ and F/H layer. (A) During exposure for five months in the field (Initial = before exposure, Final $=$ at the end of experiment). (B) In defaunated (-Fauna) and non-defaunated cores (+Fauna). Values are means $\pm \mathrm{SE} .{ }^{* *} \mathrm{P}<0.01$.

\section{Microbial biomass and respiration}

In general, $\mathrm{C}_{\text {mic }}$ and $\mathrm{BR}$ in the $\mathrm{L}$ layer (overall means of 9,308 $\pm 4,031 \mu \mathrm{g} \mathrm{C}_{\text {mic }} \mathrm{g}^{-1}$ dry weight ( $\mathrm{dw}$ ) and $47.63 \pm 20.62 \mu \mathrm{O}_{2} \mathrm{~g}^{-1} \mathrm{dw} \mathrm{h}^{-1}$, respectively) exceeded that in the $\mathrm{F} / \mathrm{H}$ layer (respective values of 4,4394 $\pm 1,685 \mu \mathrm{g} \mathrm{C}_{\text {mic }} \mathrm{g}^{-1} \mathrm{dw}$ and $43.42 \pm 17.80 \mu \mathrm{O} \mathrm{O}_{2} \mathrm{~g}^{-1} \mathrm{dw} \mathrm{h}^{-1}$ ). In defaunated cores $\mathrm{C}_{\text {mic }}$ in both the $\mathrm{L}$ and $\mathrm{F} / \mathrm{H}$ layer was significantly reduced as compared to non-defaunated cores $\left(\mathrm{F}_{1,52}=10.05, \mathrm{p}=0.002\right.$ and $\mathrm{F}_{1,52}=20.81, \mathrm{p}<0.0001$, respectively; 
Figure $3 \mathrm{~A})$. BR also was significantly reduced in defaunated cores in the $\mathrm{L}$ layer $\left(\mathrm{F}_{1,52}=\right.$ $7.61, \mathrm{p}=0.008$; Figure $3 \mathrm{~B}$ ), while in the $\mathrm{F} / \mathrm{H}$ layer it was not significantly affected (overall mean of $39.92 \pm 19.05 \mu \mathrm{O}_{2} \mathrm{~g}^{-1} \mathrm{dw} \mathrm{h}^{-1}$ ). Further, BR in the L layer in the $+\mathrm{N}$ treatment significantly exceeded that in the Ctr treatment $\left(\mathrm{F}_{1,52}=6.52, \mathrm{p}=0.01\right)$, but this was not the case in the $\mathrm{F} / \mathrm{H}$ layer (overall mean of $44.11 \pm 15.70 \mu \mathrm{l} \mathrm{O}_{2} \mathrm{~g}^{-1} \mathrm{dw} \mathrm{h} \mathrm{h}^{-1}$ ). Also, $\mathrm{C}_{\text {mic }}$ was not significantly affected by $\mathrm{N}$ addition, neither in the $\mathrm{L}$ layer nor in the $\mathrm{F} / \mathrm{H}$ layer (overall means of 9,937 $\pm 4,578$ and 4,555 $\pm 1,607 \mu \mathrm{g} \mathrm{C}_{\mathrm{mic}} \mathrm{g}^{-1} \mathrm{dw}$, respectively). Further, rotation neither significantly affected $C_{\text {mic }}$ (overall means of 9,096 $\pm 4,035$ and 4,346 $\pm 1,699 \mu \mathrm{g}$ $\mathrm{C}_{\text {mic }} \mathrm{g}^{-1} \mathrm{dw}$ in the $\mathrm{L}$ and $\mathrm{F} / \mathrm{H}$ layer, respectively) nor BR (overall means of $47.48 \pm 21.12$ and $43.52 \pm 21.77 \mu \mathrm{I} \mathrm{O}_{2} \mathrm{~g}^{-1} \mathrm{dw} \mathrm{h} \mathrm{h}^{-1}$ in the $\mathrm{L}$ and $\mathrm{F} / \mathrm{H}$ layer, respectively).

A.

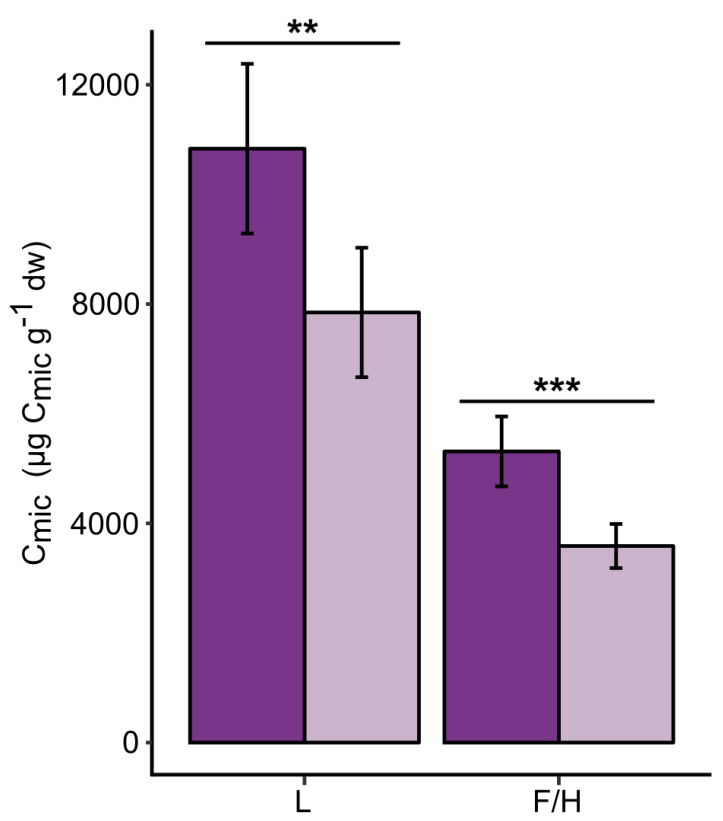

B.

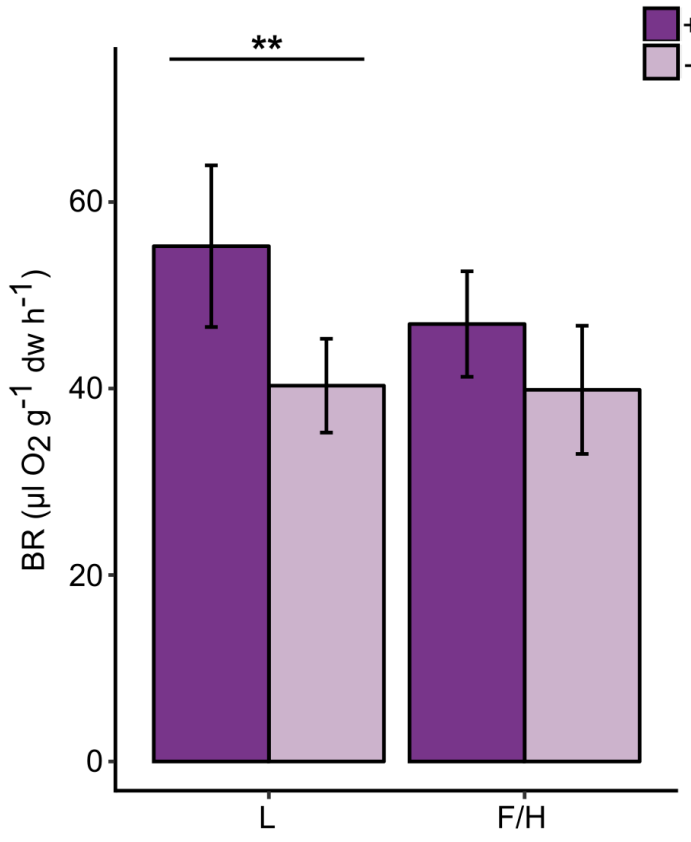

Figure 3. Effect of defaunation on microbial biomass and basal respiration in the $\mathrm{L}$ and $\mathrm{F} / \mathrm{H}$ layer. Variations in $(\mathbf{A})$ microbial biomass $\left(\mathrm{C}_{\text {mic }}\right)$ and $(\mathbf{B})$ basal respiration $(\mathrm{BR})$ in the $\mathrm{L}$ and $\mathrm{F} / \mathrm{H}$ layer of defaunated (-Fauna) and non-defaunated cores (+Fauna). Values are means $\pm \mathrm{SE}$. $* * * \mathrm{P}<$ $0.001 ; * * \mathrm{P}<0.01$. 


\section{Microbial community structure}

The concentration of Gram-positive bacteria and saprotrophic fungi significantly changed during the experiment; Gram-positive bacteria significantly increased in the L layer from an overall mean of $80.80 \pm 36.14$ to $111.01 \pm 32.13 \mathrm{nmol} \mathrm{g}^{-1}$ by the end of the experiment $\left(F_{1,26}=8.07, p=0.008\right)$ and saprotrophic fungi significantly decreased in the $F / H$ layer from an overall mean of $61.33 \pm 12.23$ to $52.31 \pm 7.05 \mathrm{nmol} \mathrm{g}^{-1}$ by the end of the experiment $\left(\mathrm{F}_{1,26}=6.42, \mathrm{p}=0.01\right)$.

The concentration of Gram-positive, Gram-negative and saprotrophic fungi markers in the L layer (overall means of $111.01 \pm 39.59,158.47 \pm 59.74$ and $200.54 \pm 77.79 \mathrm{nmol} \mathrm{g}^{-1}$, respectively) exceeded that in the $\mathrm{F} / \mathrm{H}$ layer (respective values of $76.77 \pm 14.36,94.38 \pm$ 22.24 and $52.31 \pm 13.93 \mathrm{nmol} \mathrm{g}^{-1}$ ). Gram-positive, Gram-negative and total bacterial PLFA markers were not significantly affected by any of the treatments, neither in the L nor in the $\mathrm{F} / \mathrm{H}$ layer (Table 1). By contrast, in the L layer the concentration of the saprotrophic fungal

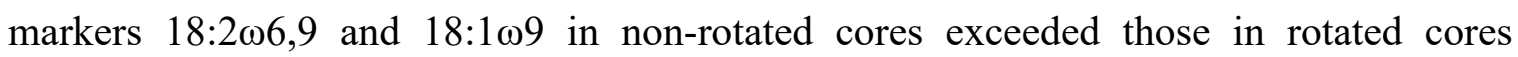
(averages of $219.61 \pm 78.33$ and $181.48 \pm 66.94 \mathrm{nmol} \mathrm{g}^{-1}$, respectively) while in the $\mathrm{F} / \mathrm{H}$ layer the concentration did not differ significantly between rotated and non-rotated cores (overall mean of $54.21 \pm 15.49 \mathrm{nmol} \mathrm{g}^{-1}$ ). Neither defaunation nor $\mathrm{N}$ addition affected the concentrations of the fungal markers in the $\mathrm{L}$ and $\mathrm{F} / \mathrm{H}$ layer.

\begin{tabular}{lccccccccc}
\hline & \multicolumn{2}{c}{$\mathbf{G r a m}^{+}$} & \multicolumn{2}{c}{$\mathbf{G a m}^{-}$} & \multicolumn{2}{c}{ Total bacteria } & \multicolumn{2}{c}{$\begin{array}{c}\text { Saprotrophic } \\
\text { fungi }\end{array}$} \\
\cline { 2 - 9 } & $\boldsymbol{F}$-value & $\boldsymbol{p}$-value & $\boldsymbol{F}$-value & $\boldsymbol{p}$-value & $\boldsymbol{F}$-value & $\boldsymbol{p}$-value & $\boldsymbol{F}$-value & $\boldsymbol{p}$-value \\
\hline Litter & & & & & & & & \\
$\quad$ +N & 2.25 & 0.14 & 0.35 & 0.56 & 0.94 & 0.34 & 0.03 & 0.87 \\
$\quad$ Rotation & 0.58 & 0.45 & 0.04 & 0.84 & 0.02 & 0.87 & $\mathbf{4 . 4 0}$ & $\mathbf{0 . 0 4}$ \\
$\quad$ Defaunation & 2.46 & 0.12 & 0.08 & 0.78 & 0.17 & 0.68 & 0.46 & 0.49 \\
F/H & & & & & & & & \\
$\quad$ +N & 0.005 & 0.94 & 0.24 & 0.62 & 0.09 & 0.77 & 0.53 & 0.47 \\
$\quad$ Rotation & 0.54 & 0.47 & 0.59 & 0.44 & 0.65 & 0.42 & 0.80 & 0.31 \\
$\quad$ Defaunation & 2.71 & 0.11 & 0.66 & 0.42 & 1.48 & 0.23 & 2.04 & 0.16 \\
\hline
\end{tabular}

Table 1. Nitrogen addition, rotation and defaunation effects on PLFA for Gram-positive, Gram-negative and total bacteria, and saprotrophic fungi. F- and p-values of linear mixed effects models on the effect of nitrogen addition $(+\mathrm{N})$, rotation and defaunation on PLFA for Grampositive, Gram-negative and total bacteria, and saprotrophic fungi in the $\mathrm{L}$ and $\mathrm{F} / \mathrm{H}$ layer of the ingrowth cores exposed in the field for five months. Significant effects are given in bold. 


\section{Microarthropods}

Generally, microarthropods were more abundant in the $\mathrm{F} / \mathrm{H}$ than in the L layer (Oribatida $17.85 \pm 25.84$ vs. $12.98 \pm 12.62$, Gamasina $3.32 \pm 5.28$ vs. $2.85 \pm 3.21$, Uropodina $4.07 \pm$ 11.65 vs. $1.60 \pm 3.01$, Prostigmata $2.17 \pm 2.91$ vs. $1.28 \pm 1.82$, Astigmata $3.90 \pm 12.66 v s$. $0.98 \pm 2.45$, Collembola $6.70 \pm 9.24$ vs. $5.92 \pm 7.01$ ind. core ${ }^{-1}$ ). Overall, microarthropod numbers were lower in defaunated than in non-defaunated cores (Oribatida $3.82 \pm 3.49 v s$. $27.01 \pm 23.53$, Gamasina $2.81 \pm 4.58$ vs. $3.38 \pm 4.16$, Uropodina $0.56 \pm 1.35$ vs. $5.17 \pm$ 11.72, Prostigmata $1.17 \pm 1.86$ vs. $2.30 \pm 2.86$, Astigmata $1.40 \pm 3.17$ vs. $3.52 \pm 12.68$, Collembola $4.48 \pm 6.45$ vs. $8.17 \pm 9.32$ ind. core $\left.^{-1}\right)$. The number of Uropodina and Prostigmata were lower in both the L (averages of $0.65 \pm 1.73$ and $1.01 \pm 1.79$ ind. core ${ }^{-1}$, respectively) and the F/H layer of defaunated cores (averages of $0.46 \pm 0.84$ and $1.34 \pm$ 1.94 ind. core ${ }^{-1}$, respectively). Further, in the $\mathrm{L}$ layer of non-defaunated cores the number of Astigmata exceeded that in defaunated cores with $1.67 \pm 3.28$ and $0.31 \pm 0.82$ ind. core $^{-}$

${ }^{1}$, respectively. Also, in the $\mathrm{F} / \mathrm{H}$ layer the number of Collembola in non-defaunated cores exceeded that in defaunated cores with $9.90 \pm 11.17$ and $3.50 \pm 5.23$ ind. core ${ }^{-1}$, respectively. Rotation generally little affected the number of microarthropods with the exception of Gamasina in the $\mathrm{F} / \mathrm{H}$ layer of rotated cores which exceeded that in non-rotated cores with averages of $4.81 \pm 6.86$ and $1.84 \pm 2.25$ ind. core $^{-1}$, respectively (Table 2 ).

\begin{tabular}{lcccccccccc}
\hline & \multicolumn{2}{c}{ Collembola } & \multicolumn{2}{c}{ Gamasina } & \multicolumn{2}{c}{ Uropodina } & \multicolumn{2}{c}{ Astigmata } & \multicolumn{2}{c}{ Prostigmata } \\
\cline { 2 - 10 } & $\boldsymbol{F}$-value & $\boldsymbol{p}$-value & $\boldsymbol{F}$-value & $\boldsymbol{p}$-value & $\boldsymbol{F}$-value & $\boldsymbol{p}$-value & $\boldsymbol{F}$-value & $\boldsymbol{p}$-value & $\boldsymbol{F}$-value & $\boldsymbol{p}$-value \\
\hline Litter & & & & & & & & & & \\
$\quad$ +N & 0.43 & 0.51 & 0.58 & 0.45 & 0.30 & 0.58 & 1.39 & 0.24 & 0.77 & 0.38 \\
$\quad$ Rotation & 0.03 & 0.85 & 0.68 & 0.41 & 2.40 & 0.12 & 1.27 & 0.26 & 0.98 & 0.32 \\
$\quad$ Defaunation & 1.01 & 0.32 & 1.06 & 0.31 & $\mathbf{1 2 . 2 5}$ & $<\mathbf{0 . 0 1}$ & $\mathbf{1 2 . 4 9}$ & $<\mathbf{0 . 0 1}$ & $\mathbf{4 . 6 1}$ & $\mathbf{0 . 0 3}$ \\
F/H & & & & & & & & & & \\
$\quad$ +N & 0.64 & 0.43 & 1.90 & 0.17 & 0.08 & 0.78 & 0.43 & 0.51 & 0.50 & 0.48 \\
$\quad$ Rotation & 0.02 & 0.87 & $\mathbf{4 . 7 1}$ & $\mathbf{0 . 0 3}$ & 0.11 & 0.74 & 0.06 & 0.81 & 0.03 & 0.85 \\
$\quad$ Defaunation & $\mathbf{1 3 . 5 1}$ & $<\mathbf{0 . 0 1}$ & $\mathbf{0 . 4 4}$ & $\mathbf{0 . 5 1}$ & $\mathbf{2 5 . 5 8}$ & $<\mathbf{0 . 0 1}$ & 1.05 & 0.31 & $\mathbf{7 . 4 6}$ & $<\mathbf{0 . 0 1}$ \\
\hline
\end{tabular}

Table 2. Nitrogen addition, rotation and defaunation effects on the abundance of Collembola, Gamasina, Uropodina, Astigmata and Prostigmata. F- and p-values of linear mixed effects models on the effect of nitrogen addition $(+\mathrm{N})$, rotation and defaunation on the abundance of Collembola, Gamasina, Uropodina, Astigmata and Prostigmata in the L and F/H layer of ingrowth cores exposed in the field for five months. Significant effects are given in bold. 
In total, 60 species of Oribatida were identified (see S1 Table for full list of species). The three most common species of Oribatida associated with the L layer were Neoamerioppia rotunda, Cultroribula zicsii and Epieremulus granulatus, whereas in the F/H layer the three most common associated species were Rostrozetes faveolatus, Nanhermannia elegantissima and Scheloribates elegans. No Oribatida species exclusively occurred in any of the treatments. The PCA defined two main gradients of variation of the Oribatida communities, separating defaunated and non-defaunated cores and differentiating litter and soil layer, which together accounted for $57.8 \%$ of the total variation (Figure 4 ).

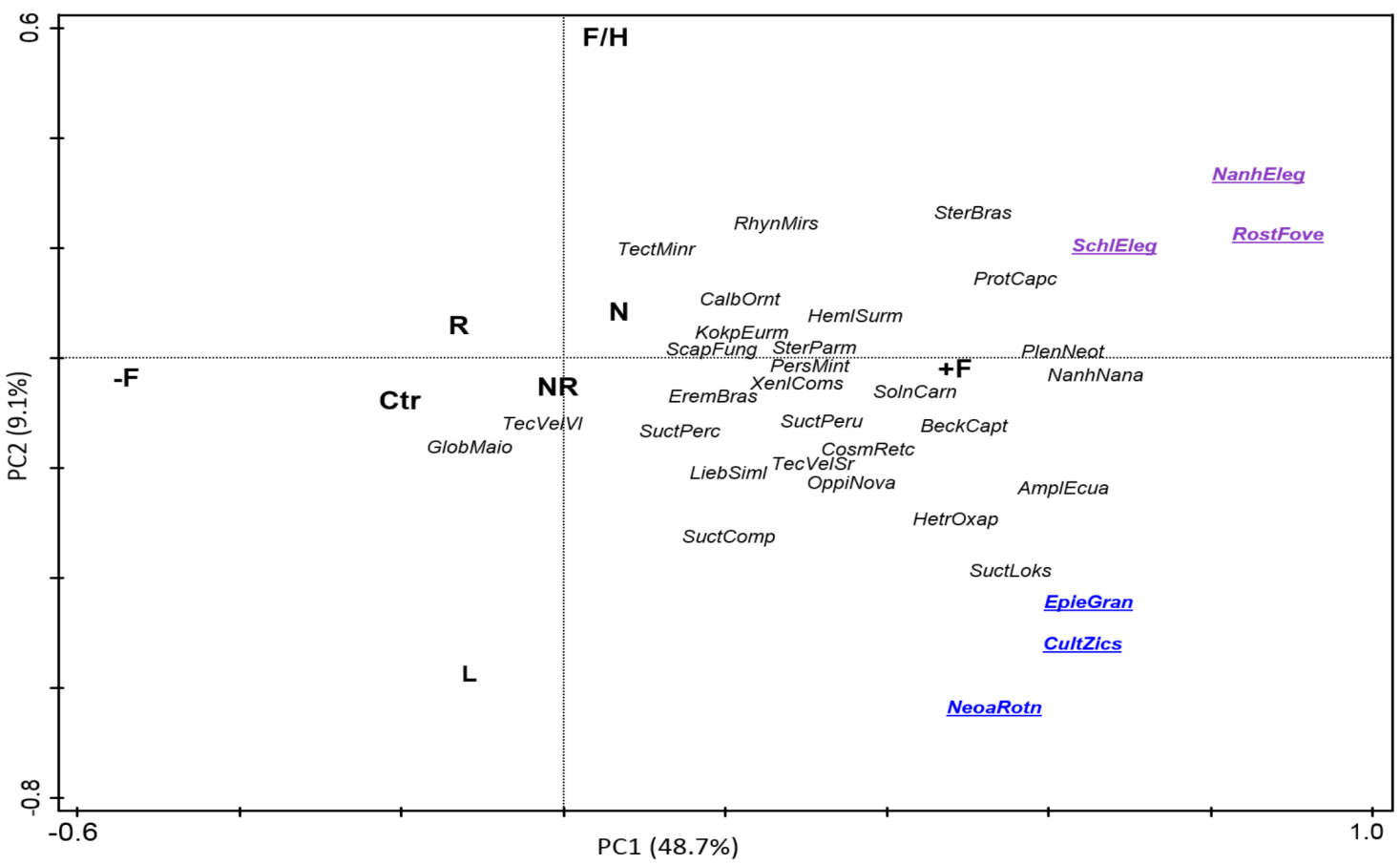

Figure 4. Principal components analysis of oribatid mite species. Principal components analysis (PCA) of oribatid mite species in control (Ctr), nitrogen addition $(\mathrm{N})$, rotated $(\mathrm{R})$, non-rotated $(\mathrm{NR})$ defaunated $(-\mathrm{F})$ and non-defaunated cores $(+\mathrm{F})$ in the $\mathrm{L}$ and $\mathrm{F} / \mathrm{H}$ layer after five months of exposure in the field. The three most abundant species in the L layer are underlined and given in blue and the three most abundant species in the $\mathrm{F} / \mathrm{H}$ layer are underlined and given in purple. Full species names are given in S1 Table.

The first principal component axis (PC1) explained the majority of variability (48.7\%) and was positively associated with non-defaunated soil cores, while the second principal component axis (PC2) explained only 9.1\% and was associated with the soil layer. MANOVA performed with NMDS axes scores confirmed that defaunation strongly 
affected the Oribatida community in both the $\mathrm{L}$ and $\mathrm{F} / \mathrm{H}$ layer $\left(\mathrm{F}_{6,49}=6,61, \mathrm{p}=0.02 ; \mathrm{F}_{6,47}\right.$ $=6.52, \mathrm{p}<0.0001$, respectively).

In general, both the richness and abundance of Oribatida were strongly affected by defaunation (Table 3), being lower in defaunated cores $\left(2.90 \pm 2.27\right.$ species core $^{-1}$ and 4.50 \pm 4.10 ind. core $^{-1}$ in the L layer, and $2.21 \pm 1.71$ species core $^{-1}$ and $3.15 \pm 2.66$ ind. core ${ }^{-1}$ in the $\mathrm{F} / \mathrm{H}$ layer) than in non-defaunated cores $\left(7.765 \pm 3.01\right.$ species core $^{-1}$ and $21.46 \pm$ 12.58 ind. core $^{-1}$ in the L layer, and $7.56 \pm 4.03$ species core ${ }^{-1}$ and $32.56 \pm 30.06$ ind. core ${ }^{1}$ in the $\mathrm{F} / \mathrm{H}$ layer). Neither rotation nor $\mathrm{N}$ addition affected the abundance or richness of microarthropods.

\begin{tabular}{lcccc}
\hline & \multicolumn{2}{c}{ Richness } & \multicolumn{2}{c}{ Abundance } \\
\cline { 2 - 5 } & F-value & p-value & F-value & p-value \\
\hline Litter & & & & \\
$+\mathrm{N}$ & $<0.01$ & 0.97 & 0.53 & 0.47 \\
Rotation & $<0.01$ & 0.95 & $<0.01$ & 0.99 \\
Defaunation & $\mathbf{4 5 . 8 0}$ & $<\mathbf{0 . 0 1}$ & $\mathbf{6 7 . 4 8}$ & $<\mathbf{0 . 0 1}$ \\
F/H & & & & \\
+N & 0.13 & 0.71 & 0.22 & 0.64 \\
Rotation & 0.18 & 0.67 & 0.05 & 0.82 \\
Defaunation & $\mathbf{8 6 . 1 0}$ & $<\mathbf{0 . 0 1}$ & $\mathbf{1 5 9 . 0 9}$ & $<\mathbf{0 . 0 1}$ \\
\hline
\end{tabular}

Table 3. Nitrogen addition, rotation and defaunation effects on the richness and abundance of Oribatida. F- and p-values of linear mixed effects models on the effect of nitrogen addition $(+\mathrm{N})$, rotation and defaunation on the richness and abundance of Oribatida in the $\mathrm{L}$ and $\mathrm{F} / \mathrm{H}$ layer of ingrowth cores exposed in the field for five months. Significant effects are given in bold.

\section{Discussion}

\section{Rotation of cores}

Our findings do not provide evidence that AMF mycelia were reduced by regular rotation of the ingrowth cores. However, the AMF fatty acid marker inside the cores decreased during the experiment in the $\mathrm{F} / \mathrm{H}$ layer. Kottke et al. (2004) observed extensive root development in the organic layer of the study sites and this likely favors the exploitation of nutrients by root associated AMF. The soil inside ingrowth cores was separated from roots 
and the reduction in AMF marker concentration in the $\mathrm{F} / \mathrm{H}$ layer material likely reflects the cutoff from the carbon supply from the plant to the fungal mycelium (Rillig 2004). The fact that the AMF marker fatty acid was not reduced by rotation of the ingrowth cores indicates that the AMF hyphae are only functioning in close association with roots without forming extensive extraradical mycelium. Further studies at the study site based on both fatty acids and microscopic inspection of AMF mycelia support this conclusion (Camenzind and Rillig 2013; Camenzind et al. 2014). Still, AMF may have affected the periphery of the nonrotated cores which are closer to living roots, with subtle effects to be detected when analyzing mixed samples from the complete core.

The reduced concentration of the AMF marker in the $\mathrm{F} / \mathrm{H}$ layer neither was associated with a decline in $\mathrm{C}_{\mathrm{mic}}$ nor in $\mathrm{BR}$, indicating that microorganisms and microbial activity inside the cores were largely independent of AMF hyphae and their exudates based on plant carbon. Obviously, microorganisms in the $\mathrm{F} / \mathrm{H}$ layer almost exclusively exploited dead organic matter resources comprising leaf litter and dead roots at later stages of decay. Notably, the reduction of AMF concentration also did not affect the abundance of soil microarthropods with the exception of Gamasina which significantly increased in the $\mathrm{F} / \mathrm{H}$ layer of rotated cores. Gamasina typically live as predators hunting for other microarthropods, predominantly Collembola, as well as Nematoda (Koehler 1997; Dhooria 2016). Since Collembola were not affected by rotation of the cores the increase in Gamasina due to rotation might have been due to increased nematode density in rotated cores. Interactions between nematodes and mycorrhiza have been assumed to be mutually inhibitory due to competition for space and food sources (Francl 1993; Pinochet et al. 1996; Borowicz 2001; Schouteden et al. 2015). However, the interactions are complex and as yet little understood in particular in tropical ecosystems (Hol and Cook 2005).

Oribatida richness, abundance and community composition were not significantly affected by rotation of the ingrowth cores. This indicates that they exclusively exploited resources inside the cores and this was independent of interruptions of fungal hyphae colonizing the cores. By contrast, Oribatida richness and abundance varied between soil horizons with both being considerably higher in the $\mathrm{F} / \mathrm{H}$ than the $\mathrm{L}$ layer. The $\mathrm{L}$ layer was colonized by species typically occurring in the litter layer of the study site such as Cultroribula zicsii 
(Illig et al. 2005), whereas the $\mathrm{F} / \mathrm{H}$ layer was colonized mostly by individuals of the genera Nanhermannia, Rostrozetes and Scheloribates typical inhabitants of F and $\mathrm{H}$ layers (Mitchell and Parkinson 1976; Illig et al. 2005). Unfortunately, little is known on food sources of tropical Oribatida species, but presumably they comprise predominantly secondary decomposers feeding on microorganisms and microbial residues, with only few primary decomposers feeding on litter (Illig et al. 2005); this may explain the dominance of Oribatida in $\mathrm{F} / \mathrm{H}$ material in the present study.

In contrast to the $\mathrm{F} / \mathrm{H}$ layer, the concentration of AMF markers in the $\mathrm{L}$ layer did not significantly change during the experiment. In litter of an intermediate stage of decomposition, AMF are likely to compete for resources with saprotrophic fungi. Although the enzymatic capability of AMF typically is inferior to that of saprotrophic fungi, they effectively capture nutrients from decomposing litter material (Hodge et al. 2001; Camenzind and Rillig 2013), and this is most effective after saprotrophic microorganisms have started to decompose the litter (Posada et al. 2012). Previous work at our study site (Marian et al. 2019) also provided evidence that the presence of mycorrhiza suppresses the activity of saprotrophic microorganisms, thereby affecting the density of microarthropods such as Collembola. In our study, however, the abundance of microarthropods did not decline with the reduction of the AMF marker. Nevertheless, we assume that antagonistic interactions between AMF and saprotrophic fungi in the L layer persisted as colonization of litter by AMF did not decline during the experiment and this may have impacted other soil microorganisms (Krashevska et al. 2010). This conclusion is supported by the fact that saprotrophic fungi in the L layer in the non-rotated cores exceeded those in rotated cores pointing to stronger competition between saprotrophic fungi and AMF in non-rotated cores. However, part of the AMF marker might have originated from spores of AMF containing high amounts of AMF marker fatty acids (Olsson 1999), but this does not explain why AMF marker fatty acids declined in the $\mathrm{F} / \mathrm{H}$ but not in the $\mathrm{L}$ layer during the experiment. 


\section{Defaunation}

Arbuscular mycorrhizal fungi did not recover from defaunation in the F/H layer and this likely is related to excluding colonization of the cores by roots (see above). Similarly, $\mathrm{C}_{\mathrm{mic}}$ did not recover from defaunation in the $\mathrm{L}$ and $\mathrm{F} / \mathrm{H}$ layer during the experiment. Potentially, grazing by microarthropods contributed to the slow recovery. However, the abundances of all soil faunal groups investigated were strongly reduced in both the $\mathrm{L}$ and $\mathrm{F} / \mathrm{H}$ layer of defaunated cores, pointing to restricted colonization of microarthropods from outside the ingrowth cores. This also indicates that the role of microarthropods in fragmenting organic material was reduced and thereby their contribution to the formation of new surface area facilitating microbial colonization (Seastedt 1984; Moore et al. 1988; Lussenhop 1992; Ruess and Lussenhop 2005). The restricted colonization by microarthropods together with the reduced $\mathrm{C}_{\text {mic }}$ in defaunated cores also might have been related to a decline in food availability due to a reduced input of root derived resources in the cores. At our study sites roots are concentrated in organic layers (Wilcke et al. 2002) and root-derived resources are increasingly recognized as being of fundamental importance in fueling soil food webs (Pollierer et al. 2007, 2012; Scheunemann et al. 2016; Zieger et al. 2017; Marian et al. 2019).

The slow recovery of $\mathrm{C}_{\text {mic }}$ and $\mathrm{BR}$ in both the $\mathrm{L}$ and $\mathrm{F} / \mathrm{H}$ layer might have been due to low quality of litter. Nitrogen concentration in litter and litter decomposition are very low at our study site and this likely is responsible for the pronounced accumulation of organic matter in organic layers (Butenschoen et al. 2014; Marian et al. 2017). Low litter quality is associated with low nutrient mobilization during decomposition and therefore, to low supply of nutrients from the $\mathrm{L}$ to the $\mathrm{F} / \mathrm{H}$ layer, and this is reflected by the decline in $\mathrm{C}_{\text {mic }}$ from the $\mathrm{L}$ layer to the $\mathrm{F} / \mathrm{H}$ layer. Microbial biomass typically follows the stratified distribution of organic matter in the soil profile of forest ecosystems (Yang and Insam 1991; Wardle 1993). Presumably, both poor mineralization of nutrients from decomposing litter, and exclusion of roots and root-derived resources contributed to the restricted recovery of $\mathrm{C}_{\text {mic }}$ in defaunated soil cores. This is supported by the fact that BR stayed constant in the $\mathrm{L}$ and $\mathrm{F} / \mathrm{H}$ layer in defaunated cores suggesting that microorganisms did not recover from the disturbance caused by defaunation. 
Defaunation also significantly affected the community composition of Oribatida in both the $\mathrm{L}$ and F/H layers. Domes et al. (2007) showed that the eggs present in soil are sufficient to ensure establishment of a diverse community of Oribatida in organic layers, although Oribatida species differ in the speed they recover from disturbance. Therefore, the reduced diversity and abundance of Oribatida in defaunated cores might have been due to both reduced availability of resources as well as limited recovery and colonization of the cores by Oribatida from the surrounding soil, suggesting that colonization by Oribatida did not reach equilibrium during the five months of the experiment.

\section{Nitrogen addition}

The concentration of the AMF marker fatty acid was not significantly affected by $\mathrm{N}$ addition, neither in the $\mathrm{L}$ nor in the $\mathrm{F} / \mathrm{H}$ layer. This contrasts results of previous studies (Camenzind et al. 2014) that AMF root colonization decreased due to $\mathrm{N}$ fertilization. The different findings are difficult to explain, but varying effects of $\mathrm{N}$ fertilization on AMF have been reported previously (reviewed in Treseder and Allen 2000; Rillig et al. 2003; Treseder 2004).

Earlier studies at our study site reported evidence that microorganisms benefited from $\mathrm{N}$ fertilization (Krashevska et al. 2010). Results of the present study support these findings, although the addition of $\mathrm{N}$ did not alter microbial biomass. However, the addition of $\mathrm{N}$ increased leaf litter decomposition rates and BR in the L layer suggesting that the availability of $\mathrm{N}$ limited microbial activity. This is supported by the lower $\mathrm{C} / \mathrm{N}$ ratio in the $\mathrm{L}$ layer in the $\mathrm{N}$ addition treatment, reflecting that the addition of $\mathrm{N}$ improved litter quality for decomposer organisms. Overall, however, this suggests that nutrient dynamics inside the cores were largely independent of AMF hyphae and exudates.

The addition of $\mathrm{N}$ increased the $\mathrm{pH}$ in the $\mathrm{F} / \mathrm{H}$ layer. Increase in $\mathrm{pH}$ may stimulate nutrient mobilization and this may result in increased microbial activity and microbial biomass (Thirukkumaran and Parkinson 2000; Vance and Chapin 2001). However, in our study N fertilization did not affect the microbial biomass levels and only little affected microbial activity in the F/H layer. Presumably, microorganisms in the F/H layer are not only limited by $\mathrm{N}$ but also by other nutrients. In fact, although increased $\mathrm{pH}$ may stimulate the 
mobilization of N, it may aggravate the limitation of P (Gallardo and Schlesinger 1994), and $\mathrm{P}$ supply is very low in the studied tropical montane rainforest (Krashevska et al. 2010; Homeier et al. 2012).

\section{Conclusions}

Results of this study suggest that in nutrient limited tropical montane rainforests AMF hyphae are in close association with roots and do not form extensive extraradical mycelia, indicating that interactions of AMF with other soil biota are restricted to the close vicinity of roots. In contrast to the $\mathrm{F} / \mathrm{H}$ layer, AMF did not decline in the $\mathrm{L}$ layer during the experiment suggesting that interactions with other soil biota are concentrated in the $\mathrm{L}$ layer where AMF likely compete with saprotrophic microorganisms for litter-derived resources. The restricted recovery of microorganisms and microarthropods after defaunation inside the cores points to the importance of root-derived resources for fueling soil food webs. Unexpectedly, $\mathrm{N}$ addition did not affect AMF suggesting that $\mathrm{N}$ dynamics inside the cores were independent of mycorrhiza, despite litter $\mathrm{N}$ concentrations were increased and this likely was responsible for the increase in microbial respiration and decomposition due to $\mathrm{N}$ addition. Further research on interactions between AMF and other soil biota under field conditions is needed to improve our understanding of their role in structuring microbial and animal communities as well as their importance for decomposition processes in tropical forest ecosystems. The concentration of these interactions in the vicinity of roots and the litter layer, as suggested by results of the present study, pose particular challenges.

\section{Acknowledgements}

We would like to thank the Deutsche Forschungsgemeinschaft (DFG FOR816) for financial support. Further, we thank the Ministerio de Ambiente del Ecuador and the Universidad Técnico Particular de Loja (UTPL) for the research permits and the center Naturaleza y Cultura Internacional (NCI) to allow us to work in the San Francisco reserve. We thank Miguel Velez Espinoza for his collaboration during the field work and Odette Gonzalez Macé for helpful comments. 


\section{References}

A'Bear AD, Jones TH, Boddy L (2014) Size matters: What have we learnt from microcosm studies ofdecomposer fungus-invertebrate interactions? Soil Biol Biochem 78:274-283

Anderson JPE, Domsch KH (1978) A physiological method for the quantitative measurement of microbial biomass in soils. Soil Biol Biochem 10:215-221

Bagyaraj D (2014) Ecology of arbuscular mycorrhizal fungi. In: Kharwar R, Upadhyay R, Dubey N, Raghuwanshi R (eds) Microbial Diversity and Biotechnology in Food Security. Springer, New Delhi, pp 133-146

Balogh J, Balogh P (1990) Oribatid mites of the neotropical region II. Elsevier Science Publishers, Budapest

Balogh J, Balogh P (2002) Identification keys to the oribatid mites of the extra-holartic regions I. Well-Press Publishing Limited, Hungary

Beck E, Ritcher M (2008) Ecological aspects of a biodiversity hotspot in the Andes of southern Ecuador. Biodivers Ecol Ser 2:195-217

Beck T, Joergensen RG, Kandeler E, et al (1997) An inter-laboratory comparison of ten different ways of measuring soil microbial biomass C. Soil Biol Biochem 29:1023-1032

Bendix J, Homeier J, Cueva Ortiz E, et al (2006) Seasonality of weather and tree phenology in a tropical evergreen mountain rain forest. Int J Biometeorol 50:370-384

Bödeker ITM, Lindahl BD, Olson A, Clemmensen KE (2016) Mycorrhizal and saprotrophic fungal guilds compete for the same organic substrates but affect decomposition differently. Funct Ecol 30:1967-1978

Borowicz VA (2001) Do arbuscular mycorrhizal fungi alter plant-pathogen relations? Ecology 82:3057-3068

Bray RH., Kurtz LT (1945) Determination of total, organic, and available forms of phosphorus in soils. Soil Sci 59:39-46

Brundrett MC, Tedersoo L (2018) Evolutionary history of mycorrhizal symbioses and global host plant diversity. New Phytol 220:1108-1115

Butenschoen O, Krashevska V, Maraun M, et al (2014) Litter mixture effects on decomposition 
in tropical montane rainforests vary strongly with time and turn negative at later stages of decay. Soil Biol Biochem 77:121-128

Camenzind T, Hempel S, Homeier J, et al (2014) Nitrogen and phosphorus additions impact arbuscular mycorrhizal abundance and molecular diversity in a tropical montane forest. Glob Chang Biol 20:3646-3659

Camenzind T, Rillig MC (2013) Extraradical arbuscular mycorrhizal fungal hyphae in an organic tropical montane forest soil. Soil Biol Biochem 64:96-102

Cardoso IM, Kuyper TW (2006) Mycorrhizas and tropical soil fertility. Agric Ecosyst Environ $116: 72-84$

Dalling JW, Heineman K, Lopez OR, et al (2016) Nutrient availability in tropical rain forests: the paradigm of phosphorus limitation. In: Goldstein G, Editors LSS (eds) Tropical Tree Physiology. Springer, pp 261-273

Dhooria MS (2016) Soil mites. In: Fundamentals of Applied Acarology. Springer, Singapore, pp $197-206$

Domes K, Scheu S, Maraun M (2007) Resources and sex: Soil re-colonization by sexual and parthenogenetic oribatid mites. Pedobiologia 51:1-11

Finlay RD (2004) Mycorrhizal fungi and their multifunctional roles. Mycologist 18:91-96

Francl LJ (1993) Interactions of nematodes with mycorrhizae and mycorrhizal fungi. In: Khan MW (ed) Nematode Interactions. Springer, Dordrecht, pp 203-216

Franklin E, Hayek T, Fagundes EP, Silva LL (2004) Oribatid mite (Acari: Oribatida) contribution to decomposition dynamic of leaf litter in primary forest, second growth, and polyculture in the Central Amazon. Brazilian J Biol 64:59-72

Frostegård Å, Bååth E (1996) The use of phospholipid fatty acid analysis to estimate bacterial and fungal biomass in soil. Biol Fertil Soils 22:59-65

Frostegård A, Tunlid A, Bååth E (1993) Phospholipid Fatty Acid composition, biomass, and activity of microbial communities from two soil types experimentally exposed to different heavy metals. Appl Environ Microbiol 59:3605-17

Gallardo A, Schlesinger WH (1994) Factors limiting microbial biomass in the mineral soil and forest floor of a warm-temperate forest. Soil Biol Biochem 26:1409-1415. 
https://doi.org/10.1016/0038-0717(94)90225-9

Gange AC, Brown VK (2002) Actions and Interactions of Soil Invertebrates and Arbuscular Mycorrhizal Fungi in Affecting the Structure of Plant Communities. In: van der Heijden MGA, Sanders IR (eds) Mycorrhizal Ecology. Ecological Studies (Analysis and Synthesis). Springer, Berlin, Heidelberg, pp 321-344

Gryndler M (2000) Interactions of arbuscular mycorrhizal fungi with other soil organisms. In: Kapulnik Y, Douds DD (eds) Arbuscular Mycorrhizas: Physiology and Function. Springer, Dordrecht, pp 239-262

Hammer M (1958) Investigations on the Oribatid fauna of the Andes mountains I. The Argentine and Bolivia. Biol Writings R Danish Acad Sci Lett 10:1-129

Hammer M (1961) Investigations on the Oribatid fauna of the Andes mountains II. Peru. Biol Writings $R$ Danish Acad Sci Lett 1:1-157

Hodge A, Campbell CD, Fitter AH (2001) An arbuscular mycorrhizal fungus accelerates decomposition and achqires nitrogen directly from organic material. Nature 413:297-299

Hol WHG, Cook R (2005) An overview of arbuscular mycorrhizal fungi-nematode interactions. Basic Appl Ecol 6:489-503

Homeier J, Breckle S, Günter S, et al (2010) Tree diversity, forest structure and productivity along altitudinal and topographical gradients in a species-rich Ecuadorian montane rain forest. Biotropica 42:140-148

Homeier J, Hertel D, Camenzind T, et al (2012) Tropical Andean forests are highly susceptible to nutrient inputs-rapid effects of experimental $\mathrm{N}$ and $\mathrm{P}$ addition to an Ecuadorian montane forest. PLoS One 7:

Illig J, Langel R, Norton RA, et al (2005) Where are the decomposers? Uncovering the soil food web of a tropical montane rain forest in southern Ecuador using stable isotopes $(15 \mathrm{~N}) . J$ Trop Ecol 21:589-593

Johansson JF, Paul LR, Finlay RD (2004) Microbial interactions in the mycorrhizosphere and their significance for sustainable agriculture. FEMS Microbiol Ecol 48:1-13

Johnson D, Leake JR, Read DJ (2001) Novel in-growth core system enables functional studies of grassland mycorrhizal mycelial networks. New Phytol 152:555-562 
Johnson NC (2010) Resource stoichiometry elucidates the structure and function of arbuscular mycorrhizas across scales. New Phytol 185:631-647

Kempson D, Lloyd M, Ghelardi R (1963) A new extractor for woodland litter. Pedobiologia 3:121

Koehler HH (1997) Mesostigmata (Gamasina, Uropodina), efficient predators in agroecosystems. Agric Ecosyst Environ 62:105-117

Kottke I, Beck A, Oberwinkler F, et al (2004) Arbuscular endomycorrhizas are dominant in the organic soil of a neotropical montane cloud forest. J Trop Ecol 20:125-129

Krashevska V, Maraun M, Ruess L, Scheu S (2010) Carbon and nutrient limitation of soil microorganisms and microbial grazers in a tropical montane rain forest. Oikos 119:1020-1028

Lehmann A, Leifheit EF, Rillig MC (2017) Mycorrhizas and Soil Aggregation. In: Collins Johnson N, Gehring C, Jansa J (eds) Mycorrhizal Mediation of Soil: Fertility, Structure, and Carbon Storage. Elsevier, pp 241-262

Leifheit EF, Verbruggen E, Rillig MC (2014) Rotation of hyphal in-growth cores has no confounding effects on soil abiotic properties. Soil Biol Biochem 79:78-80

Lussenhop J (1992) Mechanisms of microarthropod-micobial interactions in soil. Adv Ecol Res $23: 1-33$

Macfadyen A (1961) Improved funnel-type extractors for soil arthropods. J Anim Ecol 30:171184

Maraun M, Martens H, Migge S, et al (2003) Adding to "the enigma of soil animal diversity": Fungal feeders and saprophagous soil invertebrates prefer similar food substrates. Eur J Soil Biol 39:85-95

Marian F, Brown L, Sandmann D, et al (2019) Roots, mycorrhizal fungi and altitude as determinants of litter decomposition and soil animal communities in tropical montane rainforests. Plant Soil 438:1-18

Marian F, Sandmann D, Krashevska V, et al (2017) Leaf and root litter decomposition is discontinued at high altitude tropical montane rainforests contributing to carbon sequestration. Ecol Evol 7:6432-6443

Miransari M (2011) Interactions between arbuscular mycorrhizal fungi and soil bacteria. Appl 
Microbiol Biotechnol 89:917-930

Mitchell MJ, Parkinson D (1976) Ecological Society of America Fungal Feeding or Oribatid Mites (Acari: Cryptostigmata) in an Aspen Woodland Soil. Ecology 57:302-312

Moore JC, Walter DE, Hunt HW (1988) Arthropod regulation of micro and mesobiota in belowground detrital food webs. Annu Rev Entomol 33:419-435

Ngosong C, Gabriel E, Ruess L (2014) Collembola grazing on arbuscular mycorrhiza fungi modulates nutrient allocation in plants. Pedobiologia 57:171-179

Nottingham AT, Turner BL, Winter K, et al (2013) Root and arbuscular mycorrhizal mycelial interactions with soil microorganisms in lowland tropical forest. FEMS Microbiol Ecol 85:3750

Nuccio EE, Hodge A, Pett-ridge J, et al (2013) An arbuscular mycorrhizal fungus significantly modifies the soil bacterial community and nitrogen cycling during litter decomposition. Environ Microbiol 15:1870-1881

Olsson PA (1999) Signature fatty acids provide tools for determination of the distribution and interactions of mycorrhizal fungi in soil. FEMS Microbiol Ecol 29:303-310

Olsson PA, Bååth E, Jakobsen I, Söderström B (1995) The use of phospholipid and neutral lipid fatty acids to estimate biomass of arbuscular mycorrhizal fungi in soil. Mycol Res 99:623-629

Öpik M, Moora M, Liira J, Zobel M (2006) Composition of root-colonizing arbuscular mycorrhizal fungal communities in different ecosystems around the globe. J Ecol 94:778-790

Pinochet J, Calvet C, Camprubí A, Fernández C (1996) Interactions between migratory endoparasitic nematodes and arbuscular mycorrhizal fungi in perennial crops: A review. Plant Soil 185:183-190

Pollierer MM, Dyckmans J, Scheu S, Haubert D (2012) Carbon flux through fungi and bacteria into the forest soil animal food web as indicated by compound-specific $13 \mathrm{C}$ fatty acid analysis. Funct Ecol 26:978-990

Pollierer MM, Langel R, Körner C, et al (2007) The underestimated importance of belowground carbon input for forest soil animal food webs. Ecol Lett 10:729-736

Posada RH, Madriñan S, Rivera EL (2012) Relationships between the litter colonization by saprotrophic and arbuscular mycorrhizal fungi with depth in a tropical forest. Fungal Biol 
$116: 747-755$

R Core Team (2014) R: A language and environment for statistical computing. http://www.rproject.org/

Read DJ, Perez-Moreno J (2003) Mycorrhizas and nutrient cycling in ecosystems - A journey towards relevance? New Phytol 157:475-492

Renker C, Otto P, Schneider K, et al (2005) Oribatid mites as potential vectors for soil microfungi: Study of mite-associated fungal species. Microb Ecol 50:518-528

Richter M, Diertl KH, Emck P, et al (2009) Reasons for an outstanding plant diversity in the tropical Andes of Southern Ecuador. Landsc Online 12:1-35

Rillig MC (2004) Arbuscular mycorrhizae and terrestrial ecosystem processes. Ecol Lett 7:740754. https://doi.org/10.1111/j.1461-0248.2004.00620.x

Rillig MC, Treseder KK, Allen MF (2003) Global Change and Mycorrhizal Fungi. In: van der Heijden MGA, Sanders IR (eds) Mycorrhizal Ecology. Springer Berlin Heidelberg, Berlin, Heidelberg, pp 135-160

Ruess L, Chamberlain PM (2010) The fat that matters: Soil food web analysis using fatty acids and their carbon stable isotope signature. Soil Biol Biochem 42:1898-1910

Ruess L, Lussenhop J (2005) Trophic interactions of fungi and animals. In: Dighton J, Oudemans $\mathrm{P}$, White J (eds) The fungal community: its organization and role in the ecosystem. CRC, Boca Raton, pp 581-598

Scheu S (1992) Automated measurement of the respiratory response of soil microcompartments: Active microbial biomass in earthworm faeces. Soil Biol Biochem 24:1113-1118

Scheunemann N, Pausch J, Digel C, et al (2016) Incorporation of root C and fertilizer N into the food web of an arable field: Variations with functional group and energy channel. Food Webs 9:39-45

Schneider K, Renker C, Maraun M (2005) Oribatid mite (Acari, Oribatida) feeding on ectomycorrhizal fungi. Mycorrhiza 16:67-72

Schouteden N, Waele D De, Panis B, Vos CM (2015) Arbuscular mycorrhizal fungi for the biocontrol of plant-parasitic nematodes: A review of the mechanisms involved. Front Microbiol 6:1-12 
Seastedt TR (1984) The role of microarthropods in decomposition and mineralization processes. Annu Rev Entomol Vol 29 25-46

Sheldrake M, Rosenstock NP, Mangan S, et al (2018) Responses of arbuscular mycorrhizal fungi to long-term inorganic and organic nutrient addition in a lowland tropical forest. ISME J $2433-$ 2445

Smith SE, Read DJ (2008) Mycorrhizal symbiosis, 3rd edn. Academy Press, London

Subías LS (2018) Listado sistemático, sinonímico y biogeográfico de los ácaros oribátidos (Acariformes: Oribatida ) del mundo (Excepto fósiles)(13 ${ }^{\mathrm{a}}$ actualización). http://www.ucm.es/info/zoo/Artropodos/Catalogo.pdf.

Svenningsen NB, Watts-Williams SJ, Joner EJ, et al (2018) Suppression of the activity of arbuscular mycorrhizal fungi by the soil microbiota. ISME $J$ 12:1296-1307

Ter Braak C, Smilauer P (2012) Canoco reference manual and user's guide: Software for ordination

Thirukkumaran CM, Parkinson D (2000) Microbial Respiration, Biomass, Metabolic Quotient and Litter Decompostion. Soil Biol Biochem 32:59-66

Toljander JF, Artursson V, Paul LR, et al (2007) Attachment of different soil bacteria to arbuscular mycorrhizal fungal extraradical hyphae is determined by hyphal vitality and fungal species. FEMS Microbiol Lett 254:34-40

Treseder K (2004) A meta-analysis of mycorrhizal responses to nitrogen, phosphorus, and atmospheric CO2 in field studies. New Phytol 164:347-355

Treseder KK, Allen MF (2002) Direct nitrogen and phosphorus limitation of arbuscular mycorrhizal fungi: a model and field test. New Phytol 155:507-515

Treseder KK, Allen MF (2000) Mycorrhizal fungi have a potential role in soil carbon storage under elevated CO and nitrogen deposition. New Phytol 147:189-200

Vance ED, Chapin FS (2001) Substrate limitations to microbial activity in taiga forest floors. Soil Biol Biochem 33:173-188

Vašutová M, Mleczko P, López-García A, et al (2019) Taxi drivers: the role of animals in transporting mycorrhizal fungi. Mycorrhiza 
Wallander H, Ekblad A, Godbold DL, et al (2013) Evaluation of methods to estimate production, biomass and turnover of ectomycorrhizal mycelium in forests soils - A review. Soil Biol Biochem 57:1034-1047

Wardle DA (1993) Changes in the Microbial Biomass and Metabolic Quotient During Leaf Litter Succession in Some New Zealand Forest and Scrubland Ecosystems. Funct Ecol 7:346

Wilcke W, Yasin S, Abramowski U, et al (2002) Nutrient storage and turnover in organic layers under tropical montane rain forest in Ecuador. Eur J Soil Sci 53:15-27

Wullaert H, Homeier J, Valarezo C, Wilcke W (2010) Response of the N and P cycles of an oldgrowth montane forest in Ecuador to experimental low-level $\mathrm{N}$ and $\mathrm{P}$ amendments. For Ecol Manage 260:1434-1445

Yang JC, Insam H (1991) Microbial biomass and relative contributions of bacteria and fungi in soil beneath tropical rain forest, Hainan Island, China. J Trop Ecol 7:385-393

Zelles L (1999) Fatty acid patterns of phospholipids and lipopolysaccharides in the characterisation of microbial communities in soil: A review. Biol Fertil Soils 29:111-129

Zelles L (1997) Phospholipid fatty acid profiles in selected members of soil microbial communities. Chemosphere 275-294

Zieger SL, Ammerschubert S, Polle A, Scheu S (2017) Root-derived carbon and nitrogen from beech and ash trees differentially fuel soil animal food webs of deciduous forests. PLoS One 12:1-14 


\section{Supplementary Material}

S1 Table. List of Oribatida species, abbreviations used in Fig 4 and the soil layer in which where found.

\begin{tabular}{|c|c|c|c|c|c|}
\hline Family & Species name & Abbreviation & $\begin{array}{l}\text { Used in } \\
\text { PCA }\end{array}$ & $\mathbf{L}$ & $\mathbf{F} / \mathbf{H}$ \\
\hline Hermanniellidae & $\begin{array}{c}\text { Ampullobates ecuadoriensis } \\
\text { (Ermilov, 2013) }\end{array}$ & AmplEcua & $\mathrm{x}$ & $\mathrm{x}$ & $\mathrm{x}$ \\
\hline Oppiidae & $\begin{array}{l}\text { Arcoppia dechambrierorum } \\
\text { (Mahunka, 1983) }\end{array}$ & & & & $\mathrm{x}$ \\
\hline Dampfiellidae & $\begin{array}{c}\text { Beckiella capitulum } \\
\text { (Balogh \& Mahunka, 1978) }\end{array}$ & BeckCapt & $\mathrm{x}$ & $\mathrm{x}$ & $\mathrm{x}$ \\
\hline Oppiidae & $\begin{array}{l}\text { Brachioppia cuscensis } \\
\text { (Hammer, 1961) }\end{array}$ & & & & $\mathrm{x}$ \\
\hline Oripodidae & $\begin{array}{c}\text { Calobates ornatus } \\
\text { (Mahunka, 1986) }\end{array}$ & CalbOrnt & $\mathrm{x}$ & $\mathrm{x}$ & $\mathrm{x}$ \\
\hline Carabodidae & $\begin{array}{l}\text { Carabodes nigrosetosus } \\
\text { (Mahunka, 1979) }\end{array}$ & & & $\mathrm{x}$ & $\mathrm{x}$ \\
\hline Damaeolidae & $\begin{array}{l}\text { Caudamaeolus petalus } \\
\text { (P. Balogh, 1988) }\end{array}$ & & & & $\mathrm{x}$ \\
\hline Ceratoppiidae & $\begin{array}{l}\text { Ceratorchestes cornutus } \\
\text { (Mahunka, 1982) }\end{array}$ & & & & $\mathrm{x}$ \\
\hline Ceratoppiidae & $\begin{array}{c}\text { Ceratorchestes globosus } \\
\text { (Balogh \& Mahunka, 1969) }\end{array}$ & & & $\mathrm{x}$ & \\
\hline Microzetidae & $\begin{array}{c}\text { Cosmozetes reticulatus } \\
\text { (Balogh, 1962) }\end{array}$ & CosmRetc & $\mathrm{x}$ & $\mathrm{x}$ & $\mathrm{x}$ \\
\hline Astegistidae & $\begin{array}{c}\text { Cultroribula zicsii } \\
\text { (Balogh \& Mahunka, 1981) }\end{array}$ & CultZics & $\mathrm{x}$ & $\mathrm{x}$ & $\mathrm{x}$ \\
\hline Damaeidae & $\begin{array}{l}\text { Damaeus flagellatus } \\
\text { (Wang, 1994) }\end{array}$ & & & $\mathrm{x}$ & \\
\hline Caleremaeidae & $\begin{array}{c}\text { Epieremulus granulatus } \\
\text { (Balogh \& Mahunka, 1979) }\end{array}$ & EpieGran & $\mathrm{x}$ & $\mathrm{x}$ & $\mathrm{x}$ \\
\hline Eremulidae & $\begin{array}{c}\text { Eremulus brasiliensis } \\
\text { (Pére-Íñigo \& Baggio, 1985) }\end{array}$ & EremBras & $\mathrm{x}$ & $\mathrm{x}$ & $\mathrm{x}$ \\
\hline Eremulidae & $\begin{array}{c}\text { Eremulus rigidisetus } \\
\text { (Balogh \& Mahunka, 1969) }\end{array}$ & & & & $\mathrm{x}$ \\
\hline Oppiidae & $\begin{array}{l}\text { Gittella flagellata } \\
\text { (Mahunka, 1983) }\end{array}$ & & & & $\mathrm{x}$ \\
\hline Oppiidae & $\begin{array}{l}\text { Globoppia maior } \\
\text { (Hammer, 1962) }\end{array}$ & GlobMaio & $\mathrm{x}$ & $\mathrm{x}$ & $\mathrm{x}$ \\
\hline Granuloppiidae & $\begin{array}{l}\text { Hammerella parasufflata } \\
\text { (Ermilov, 2013) }\end{array}$ & & & & $\mathrm{x}$ \\
\hline Hemileiidae & $\begin{array}{l}\text { Hemileius suramericanus } \\
\text { (Hammer, 1958) }\end{array}$ & HemlSurm & $\mathrm{x}$ & $\mathrm{x}$ & $\mathrm{x}$ \\
\hline Heterobelbidae & $\begin{array}{c}\text { Heterobelba oxapampensis } \\
\text { (Beck, 1962) }\end{array}$ & HetrOxap & $\mathrm{x}$ & $\mathrm{x}$ & $\mathrm{x}$ \\
\hline
\end{tabular}




\begin{tabular}{|c|c|c|c|c|c|}
\hline Family & Species name & Abbreviation & $\begin{array}{l}\text { Used in } \\
\text { PCA }\end{array}$ & $\mathbf{L}$ & $\mathbf{F} / \mathbf{H}$ \\
\hline Oppiidae & $\begin{array}{c}\text { Kokoppia euramosa } \\
\text { (Balogh \& Mahunka, 1969) }\end{array}$ & KokpEurm & $\mathrm{x}$ & & $\mathrm{x}$ \\
\hline Oppiidae & $\begin{array}{c}\text { Lanceoppia zicsica } \\
\text { (Mahunka, 1988) }\end{array}$ & & & $\mathrm{x}$ & \\
\hline Microzetidae & $\begin{array}{c}\text { Licnozetes granulatus } \\
\text { (Balogh \& Mahunka, 1969) }\end{array}$ & & & & $\mathrm{x}$ \\
\hline Liebstadiidae & $\begin{array}{c}\text { Liebstadia pannonica } \\
\text { (Willmann, 1951) }\end{array}$ & & & $\mathrm{x}$ & $\mathrm{x}$ \\
\hline Liebstadiidae & $\begin{array}{c}\text { Liebstadia similis } \\
\text { (Michael, 1888) }\end{array}$ & LiebSiml & $\mathrm{x}$ & $\mathrm{x}$ & $\mathrm{x}$ \\
\hline Nanhermammiidae & $\begin{array}{c}\text { Nanhermannia elegantissima } \\
\text { (Hammer, 1958) }\end{array}$ & NanhEleg & $\mathrm{x}$ & $\mathrm{x}$ & $\mathrm{x}$ \\
\hline Nanhermammiidae & $\begin{array}{c}\text { Nanhermannia nana } \\
\text { (Nicolet, 1855) }\end{array}$ & NanhNana & $\mathrm{x}$ & $\mathrm{x}$ & $\mathrm{x}$ \\
\hline Oppiidae & $\begin{array}{c}\text { Neoamerioppia rotunda } \\
\text { (Hammer, 1958) }\end{array}$ & NeoaRotn & $\mathrm{x}$ & $\mathrm{x}$ & $\mathrm{x}$ \\
\hline Galumnidae & $\begin{array}{l}\text { Neoctenogalumna longiciliata } \\
\text { (Ermilov 2013) }\end{array}$ & & & & $\mathrm{x}$ \\
\hline Oppiidae & $\begin{array}{c}\text { Oppiella nova } \\
\text { (Oudemans, 1902) }\end{array}$ & OppiNova & $\mathrm{x}$ & $\mathrm{x}$ & $\mathrm{x}$ \\
\hline Microzetidae & $\begin{array}{l}\text { Orthozetes bidentatus } \\
\text { (Ermilov, 2013) }\end{array}$ & & & $\mathrm{x}$ & \\
\hline Oppiidae & $\begin{array}{l}\text { Oxyoppia polynesia } \\
\text { (Hammer, 1972) }\end{array}$ & & & & $\mathrm{x}$ \\
\hline Scheloribatidae & $\begin{array}{l}\text { Perscheloribates minutus } \\
\text { (Pletzen, 1965) }\end{array}$ & PersMint & $\mathrm{x}$ & $\mathrm{x}$ & $\mathrm{x}$ \\
\hline Pheroliodidae & $\begin{array}{l}\text { Pheroliodes intermedius } \\
\text { (Hammer, 1961) }\end{array}$ & & & & $\mathrm{x}$ \\
\hline Plasmobatidae & $\begin{array}{c}\text { Plasmobates pagoda } \\
\text { (Grandjean, 1929) }\end{array}$ & & & & $\mathrm{x}$ \\
\hline Tetracondylidae & $\begin{array}{l}\text { Plenotocepheus neotropicus } \\
\text { (Ermilov, 2013) }\end{array}$ & PlenNeot & $\mathrm{x}$ & $\mathrm{x}$ & $\mathrm{x}$ \\
\hline Protoribatidae & $\begin{array}{c}\text { Protoribates capucinus } \\
\text { (Mihelcic, 1958) }\end{array}$ & ProtCapc & $\mathrm{x}$ & $\mathrm{x}$ & $\mathrm{x}$ \\
\hline Oripodidae & $\begin{array}{c}\text { Pteroripoda minutissima } \\
\text { (Balogh \& Mahunka, 1974) }\end{array}$ & & & $\mathrm{x}$ & $\mathrm{x}$ \\
\hline Rhynchoribatidae & $\begin{array}{c}\text { Rhynchoribates grandis } \\
\text { (Hammer, 1961) }\end{array}$ & & & $\mathrm{x}$ & $\mathrm{x}$ \\
\hline Rhynchoribatidae & $\begin{array}{c}\text { Rhynchoribates mirus } \\
\text { (Beck, 1961) }\end{array}$ & RhynMirs & $\mathrm{x}$ & $\mathrm{x}$ & $\mathrm{x}$ \\
\hline Haplozetidae & $\begin{array}{c}\text { Rostrozetes foveolatus } \\
\text { (Sellnick, 1925) }\end{array}$ & RostFove & $\mathrm{x}$ & $\mathrm{x}$ & $\mathrm{x}$ \\
\hline Cymbaeremaeidae & $\begin{array}{c}\text { Scapheremaeus fungisetosus } \\
\text { (Ríos \& Palacios-Vargas, } \\
\text { 1998) }\end{array}$ & ScapFung & $\mathrm{x}$ & $\mathrm{x}$ & $\mathrm{x}$ \\
\hline Microzetidae & $\begin{array}{c}\text { Schalleria brevisetosa } \\
\text { (Ermilov, 2013) }\end{array}$ & & & & $\mathrm{x}$ \\
\hline
\end{tabular}




\begin{tabular}{|c|c|c|c|c|c|}
\hline Family & Species name & Abbreviation & $\begin{array}{l}\text { Used in } \\
\text { PCA }\end{array}$ & $\mathbf{L}$ & $\mathbf{F} / \mathbf{H}$ \\
\hline Scheloribatidae & $\begin{array}{l}\text { Scheloribates elegans } \\
\text { (Hammer, 1958) }\end{array}$ & SchlEleg & $\mathrm{x}$ & $\mathrm{x}$ & $\mathrm{x}$ \\
\hline Plasmobatidae & $\begin{array}{l}\text { Solenozetes carinatus } \\
\text { (Hammer, 1961) }\end{array}$ & SolnCarn & $\mathrm{x}$ & $\mathrm{x}$ & $\mathrm{x}$ \\
\hline Plasmobatidae & $\begin{array}{l}\text { Solenozetes flagellifer } \\
\text { (Mahunka, 1983) }\end{array}$ & & & $\mathrm{x}$ & $\mathrm{x}$ \\
\hline Sternoppiidae & $\begin{array}{c}\text { Sternoppia brasiliensis } \\
\text { (Franklin \& Woas, 1992) }\end{array}$ & SterBras & $\mathrm{x}$ & & $\mathrm{x}$ \\
\hline Sternoppiidae & $\begin{array}{c}\text { Sternoppia mirabilis } \\
\text { (Balogh \& Mahunka, 1968) }\end{array}$ & & & & $\mathrm{x}$ \\
\hline Sternoppiidae & $\begin{array}{c}\text { Sternoppia paramirabilis } \\
\text { (Balogh \& Mahunka, 1968) }\end{array}$ & SterParm & $\mathrm{x}$ & & $\mathrm{x}$ \\
\hline Suctobelbidae & $\begin{array}{c}\text { Suctobelbella complexa } \\
\text { (Hammer, 1958) }\end{array}$ & SuctComp & $\mathrm{x}$ & $\mathrm{x}$ & $\mathrm{x}$ \\
\hline Suctobelbidae & $\begin{array}{c}\text { Suctobelbella loksai } \\
\text { (Balogh \& Mahunka, 1981) }\end{array}$ & SuctLoks & $\mathrm{x}$ & $\mathrm{x}$ & $\mathrm{x}$ \\
\hline Suctobelbidae & $\begin{array}{c}\text { Suctobelbella peracuta } \\
\text { (Balogh \& Mahunka, 1980) }\end{array}$ & SuctPerc & $\mathrm{x}$ & $\mathrm{x}$ & $\mathrm{x}$ \\
\hline Suctobelbidae & $\begin{array}{c}\text { Suctobelbila peruensis } \\
\text { (Woas, 1986) }\end{array}$ & SuctPeru & $\mathrm{x}$ & $\mathrm{x}$ & $\mathrm{x}$ \\
\hline Suctobelbidae & $\begin{array}{l}\text { Suctobelbella semiplumosa } \\
\text { (Balogh \& Mahunka, 1967) }\end{array}$ & & & & $\mathrm{x}$ \\
\hline Tectocepheidae & $\begin{array}{c}\text { Tectocepheus minor } \\
\text { (Berlese, 1903) }\end{array}$ & TectMinr & $\mathrm{x}$ & $\mathrm{x}$ & $\mathrm{x}$ \\
\hline Tectocepheidae & $\begin{array}{c}\text { Tectocepheus velatus } \\
\text { sarekensis } \\
\text { (Trägårdh, 1910) }\end{array}$ & TecVelSr & $\mathrm{x}$ & $\mathrm{x}$ & $\mathrm{x}$ \\
\hline Tectocepheidae & $\begin{array}{l}\text { Tectocepheus velatus velatus } \\
\text { (Michael, 1880) }\end{array}$ & TecVelVl & $\mathrm{x}$ & $\mathrm{x}$ & $\mathrm{x}$ \\
\hline Teratoppiidae & $\begin{array}{l}\text { Teratoppia pluripectinata } \\
\text { (Balogh \& Mahunka, 1978) }\end{array}$ & & & $\mathrm{x}$ & \\
\hline Liebstadiidae & $\begin{array}{c}\text { Totobates discifer } \\
\text { (Hammer, 1961) }\end{array}$ & & & & $\mathrm{x}$ \\
\hline Lohmanniidae & $\begin{array}{l}\text { Xenolohmannia comosa } \\
\text { (P. Balogh, 1984) }\end{array}$ & XenlComs & $\mathrm{x}$ & $\mathrm{x}$ & $\mathrm{x}$ \\
\hline
\end{tabular}


Chapter 5

\section{General discussion}
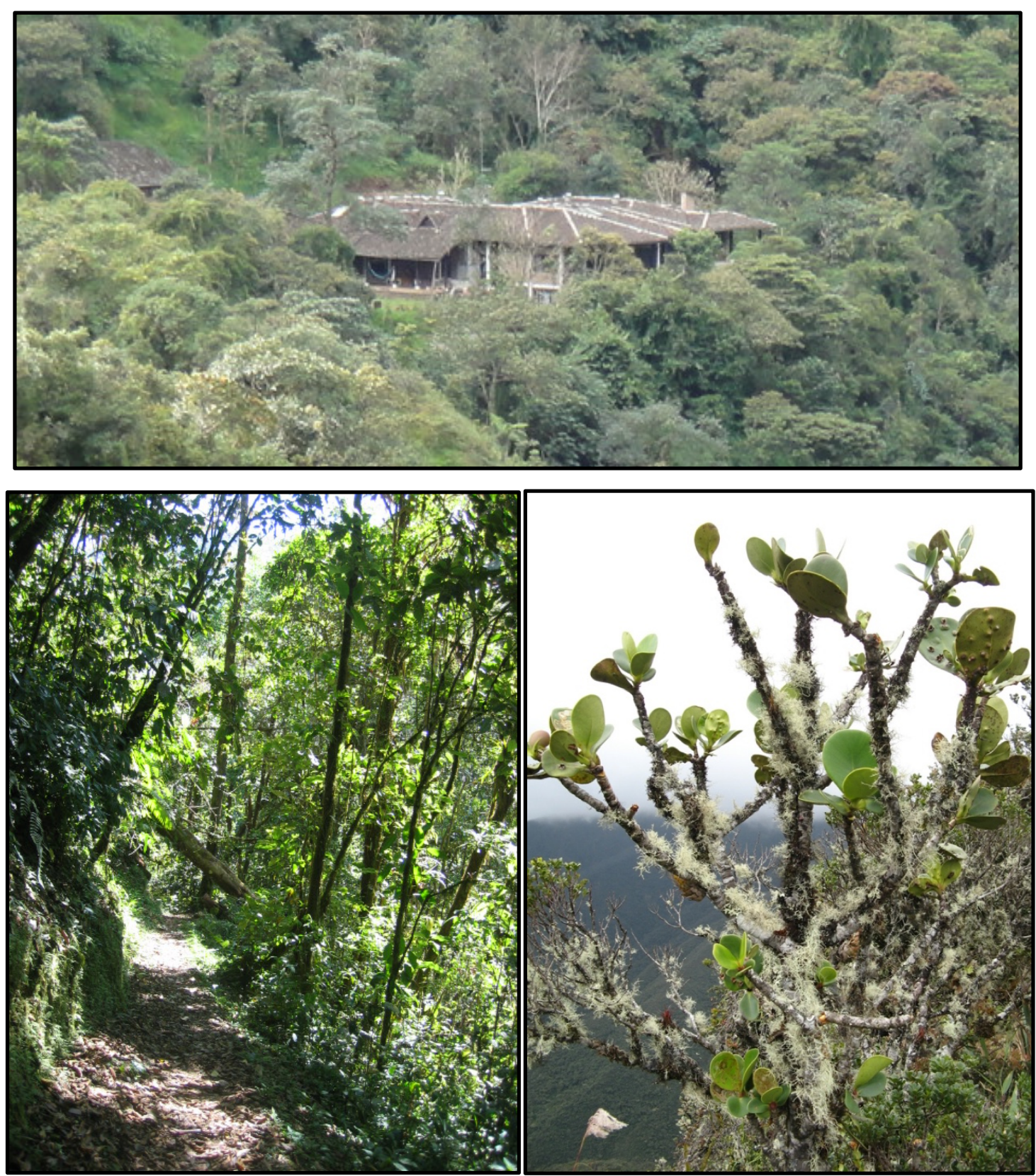
Belowground communities are assumed to be fueled principally by plant litter- and rootderived resources (Hättenschwiler et al. 2005). Diversity in quantity and quality of resources provided by plants strongly modifies decomposer organisms and thereby influence litter decomposition and nutrient mineralization processes. Higher plant diversity is generally assumed to improve habitat conditions and availability of resources, thereby improving the abundance and activity of decomposer organisms. Nonetheless, the debate on how plant species diversity influences decomposer organism is still open, and plant litter identity, which encompasses all specific litter chemical and physical characteristics of a single species, increasingly is considered as a major driver of decomposer abundance and diversity. In spite of the huge diversity of plant and animals in the Andean tropical montane rainforest ecosystems, little is known on the impact of plant litter diversity and root resources on the abundance, activity and diversity of soil communities and thereby litter decomposition processes, particularly during early stages of decomposition (Krashevska et al. 2017; Marian et al. 2017, 2019).

In this thesis I investigated the impacts of leaf litter diversity and root resources on microorganisms and decomposer microarthropods during the early stages of litter decomposition in tropical montane rainforest ecosystems. Using leaf litter mixtures the study presented in Chapter 2 investigated whether higher leaf litter diversity favors the abundance and activity of soil decomposers during early stages of decomposition. Further, comparing leaf and root litter along an altitudinal gradient, the study reported in Chapter 3 evaluated the effect of plant litter quality as structuring force of the abundance and activity of soil decomposer organisms. The study presented in Chapter 3 further evaluated the contribution of decomposer microarthropods to leaf and root litter decomposer during early stages of litter decomposition. In the studied tropical montane rainforests, the high concentration of roots in organic layers and the abundance of AM fungi (Wilcke et al. 2002; Kottke et al. 2004; Camenzind and Rillig 2013) might favor the abundance and activity of soil microorganisms and microarthropods. Using rotated ingrowth cores, the study presented in Chapter 4 assessed the impact of root-derived resources and AM fungi colonization on soil microorganisms and microarthropods within the organic layer and their responses with nutrient additions 


\section{Litter identity drives decomposer organisms and decomposition rates during early stages of decomposition}

The results presented in Chapter 2 showed that leaf litter diversity partially explained changes in the abundance and activity of soil microorganisms, but was a poor predictor of the abundance of soil microarthropods in the studied tropical montane rainforests. Notably, however, the decrease in the abundance of microorganisms with higher litter diversity by the end of early stages of decomposition indicates an accumulation of recalcitrant compounds. This reflects the preferential exploitation of labile carbon compounds by opportunistic microorganisms during early stages of decomposition (Berg and McClaugherty 2008; Berg 2014), and the general low quality of the leaf litter material (high C-to-N ratio) in this tropical rainforest ecosystem (Butenschoen et al. 2014).

Contrasting leaf litter diversity, leaf litter identity explained the majority of variation in the abundance and activity of soil organisms during early stages of decomposition. The differential responses of soil biota to litter identity were closely associated with differences in the initial chemical composition of the litter species studied. However, the initial chemical composition of leaf litter was insufficient to explain variations in the abundance of soil microarthropods, suggesting that physical traits might play an important role driving their abundances as has been demonstrated in earlier studies in temperate forest ecosystems (Kaneko and Salamanca 1999; Hoorens et al. 2010). The results also suggest that traits associated with the identity of litter species determine the quality of litter resources and function as key driver of the response of soil biota during early stages of decomposition in the studied tropical montane rainforest.

The results presented in Chapters 2 and 4 also indicate that changes in litter quality during decomposition are directly related to changes in microbial community functions, and are thereby reflected in decomposition rates. These findings support results of previous studies in the region (Illig et al. 2008, 2010; Marian et al. 2017) indicating that variations in decomposition rates during early stages of litter decomposition in montane rainforests strongly depend on the impact of litter quality on decomposer organisms. 
Quality of plant litter resources has been shown to decrease with increasing altitude in the study region (Maraun et al. 2008; Rillig et al. 2013; Marian et al. 2017), and decomposition rates were previously found to follow this pattern during early stages of litter decomposition (Marian et al. 2017). However, the results presented in Chapter 3 indicate that this may only be the case in root litter material. Contrasting the findings of Marian et al. (2017), leaf litter decomposition rates presented in Chapter 3 were highest at $2000 \mathrm{~m}$, and these changes were not linked to a higher litter quality (as compared to 1000 and $3000 \mathrm{~m}$ ). The results suggest that in the studied tropical montane rainforests, differences in the availability of nutrients associated with local litter quality appear to be more important factors for the decomposition of root litter than leaf litter. Presumably, buffered environmental conditions in the soil favor litter quality as the primary driving factor for root litter decomposition. Notably, leaf litter decomposition patterns presented in Chapter 3 were similar to those reported by Marian et al. (2019). Interestingly, both studies took place during low-rainfall periods in the study area (Bendix et al. 2006), suggesting that seasonal variations, particularly drought, might override the primacy of litter quality as major driver of decomposer organisms during early stages of decomposition along the altitudinal gradient investigated here. However, virtually nothing is known about seasonal changes in the soil fauna community of tropical montane rainforests.

\section{Decomposer microarthropods play a minor role during early stages of litter decomposition}

The results presented in Chapters 2, 3 and 4 indicate that decomposer microarthropod abundance little affects decomposition processes at early stages of litter decomposition in the studied tropical montane rainforests. This supports previous findings in the study region (Illig et al. 2008; Marian et al. 2018) indicating that decomposition of litter material during early stages of decomposition is driven predominantly by microorganisms, while microarthropods are of little importance. However, both decomposer groups studied in more detail, Oribatida and Collembola, may play a more important role at more advanced stages of decomposition when the litter palatability has been improved by intensive microbial action (Bardgett 2005; Das and Joy 2009; Marian et al. 2018). Indeed, results of 
the study presented in Chapter 2 indicated a stronger relationship between the abundance of decomposer microarthropods and the degree of litter decomposition, with the abundance of both Collembola and Oribatida increasing towards the end of the early decomposition stage. Nonetheless, as indicated by the results presented in Chapter 3, microarthropods facilitate litter decomposition at high altitude by grazing on microorganisms or fragmentation of the litter material. Presumably, this stimulation of litter decomposition by microarthropods is related to unfavorable climatic conditions and low quality of the litter material, hampering the attack of the litter by microorganisms.

The studies presented in Chapters 2 and 3 showed that the abundance of Collembola and Oribatida, as well as Oribatida community structure, were not closely associated with microbial biomass, even though microorganisms are known to be their major food resources (Maraun et al. 2003; Scheu et al. 2005; Dhooria 2016). In the studied tropical montane rainforests roots grow into and throughout the organic layer (Wilcke et al. 2002; Kottke et al. 2004), and root-derived resources are increasingly recognized as being of fundamental importance in fueling soil food webs (Pollierer et al. 2007, 2012; Zieger et al. 2017; Marian et al. 2019). The fact that the abundance of decomposer microarthropods was not closely related to bulk microbial biomass (Chapter 2), and microarthropod abundance did not recover after defaunation in cores that were detached from living roots (Chapter 3) indicates that decomposer microarthropod communities in tropical montane rainforests are fueled predominantly by root-derived resources and litter materials at later stages of decay.

The results presented in Chapter 3 also demonstrate that the abundance of Oribatida and Collembola varies between leaf and root litter. The higher density of Oribatida and Collembola in root litter compared to leaf litter suggests that roots provide more resources for decomposer microarthropods during early stages of decay than litter does. However, the higher densities of Oribatida and Collembola may also be related to the position of the litter material in the soil, with root litter in the soil providing more stable microclimatic conditions than leaf litter exposed in the litter layer (Fujii and Takeda 2017). The results further suggest that, even though Oribatida and Collembola comprise different trophic levels and differ in various ecological traits (Siepel 1994; Scheu 2002; Schneider et al. 
2004), they contribute in similar ways to early-stage litter decomposition in tropical montane rainforests.

\section{AM fungi: an important actor for determining the abundance and activity of microbial communities during early stages of decomposition}

The results presented in Chapter 4 indicate that the colonization of soil cores by AM fungi, and thereby also their impact on soil organisms differs with the depth of the soil organic layer. Vertical stratification of AM fungi colonization has been previously reported in tropical Andean montane rainforests (Aristizábal et al. 2004; Camenzind and Rillig 2013). In the litter layer of the studied tropical montane rainforest, the results suggest antagonistic interactions between AM fungi and saprotrophic microorganisms, presumably because both compete for the same nutrient resources. This result not only supports the view that AM fungi capture nutrients from decomposing litter material in spite of their lack of degradative capability (Hodge et al. 2001; Talbot et al. 2008; Camenzind and Rillig 2013; Nuccio et al. 2013), but also indicates that AM fungi exert an important role during the early stages of leaf-litter decomposition in the studied tropical montane rainforests. Indeed, the results presented in Chapter 4 indicated that nutrient exploitation by AM fungi likely suppresses the activity of saprotrophic fungi in the litter layer. Further, the dominance of AM fungi during early stages of decomposition may contribute to the low abundance of microarthropods in the litter layer, since AM fungi are little consumed by microarthropods (Potapov et al. 2019). This might contribute to the lack of relationship between microarthropod abundance and microorganisms discussed above.

Unlike the litter layer, AM fungi significantly decreased during the experiment in the fermentation/humus $(\mathrm{F} / \mathrm{H})$ layer. This was unexpected since $\mathrm{AM}$ fungi were anticipated to favor the exploitation of nutrients in the heavily rooted organic layers of the study sites (Wilcke et al. 2002; Kottke et al. 2004), and thereby affect the abundance and activity of soil microorganisms and microarthropods. Presumably, contrasting previous findings in the studied rainforest (Camenzind and Rillig 2013), AM fungi do not form pronounced extraradical mycelia in organic layers that can be cut by rotation of ingrowth cores. Rather, 
AM fungi only function in close association with living roots and the carbon supplied by plants to fungi is not or minimally translocated by extraradical hyphae outside the root. Potentially, low litter quality and strong nutrient limitation of decomposition processes enforce confinement of AM fungi near the root surface. This also suggests that in the $\mathrm{F} / \mathrm{H}$ layer of the studied tropical montane rainforests, interactions between AM fungi and other soil biota are restricted to the close vicinity of roots and cannot be effectively manipulated by using rotation of hyphal ingrowth cores.

The tropical montane rainforests investigated have been shown to be co-limited by both $\mathrm{N}$ and P (Homeier et al. 2012), and the addition of both nutrients has been documented to decrease AM fungi abundance and diversity (Camenzind et al. 2014) as well as microbial biomass (Krashevska et al. 2008). However, as presented in Chapter 4, the addition of $\mathrm{N}$ did not change the abundance of AM fungi nor the saprotrophic microbial communities. This suggests that increased $\mathrm{N}$ availability might aggravate the limitation of other nutrients such as P (Gallardo and Schlesinger 1994; Li et al. 2016), resulting in a lack of effect on the activity of saprotrophic communities or in a change in the dominant role of AM fungi. Overall, the results presented in Chapter 4 indicate that investigating interactions of arbuscular mycorrhiza with soil microarthropods in tropical montane rainforests is more complex than assumed previously and requires improvement of existing methodologies for excluding arbuscular mycorrhiza, as well as long-term experiments to investigate soil fauna - mycorrhiza interactions in these forests. 


\section{Conclusion}

The findings presented in this thesis indicate that soil biota communities in Andean tropical montane rainforests are structured by leaf-litter identity rather than leaf-litter diversity during early stages of litter decomposition. The results further suggest that litter decomposition processes during early stages of decomposition are mainly driven by microorganisms, with the contribution of microarthropods relevant only at high altitudes, where litter quality is particularly low and climatic conditions are unfavorable. Generally, microarthropod abundance and diversity were not closely associated with changes in microbial characteristics. Rather, the results suggest that the stage of litter decomposition and availability of root-derived resources function as major drivers of the structure of microarthropod communities. Further, the results suggest that colonization of litter materials by AM fungi and their impact on soil decomposer biota varies with soil depth. AM fungi in the litter layer likely compete with saprotrophic microorganisms for litterderived nutrients and capture nutrients predominantly from litter at early stages of decomposition, while in the $\mathrm{F} / \mathrm{H}$ layer remain in immediate vicinity of living roots. This highlights that the role of AM fungi in affecting the abundance and activity of microbial communities in the studied tropical montane rainforests is likely to be restricted to the close vicinity of roots at least during early stages of litter decomposition.

Overall, the studies presented in this thesis contributed to a better understanding of key drivers of decomposer communities in Andean tropical rainforest ecosystems. The results improved our understanding of the role of plant species diversity as a key driver of decomposer communities, and indicated that in tropical montane rainforest ecosystems litter identity outweighs litter diversity in determining decomposer community structure and functioning. More detailed studies are required to identify the plant litter traits responsible for litter identity effects on soil decomposer communities and to investigate the role of root-derived resources in structuring decomposer communities and thereby the functioning of tropical montane rainforest ecosystems. 


\section{References}

Aristizábal C, Rivera EL, Janos DP (2004) Arbuscular mycorrhizal fungi colonize decomposing leaves of Myrica parvifolia, M. pubescens and Paepalanthus sp. Mycorrhiza 14:221-228

Bardgett RD (2005) The biology of soil: A community and ecosystem approach. Oxford University Press, Oxford, UK

Bendix J, Homeier J, Cueva Ortiz E, et al (2006) Seasonality of weather and tree phenology in a tropical evergreen mountain rain forest. Int J Biometeorol 50:370-384

Berg B (2014) Decomposition patterns for foliar litter - A theory for influencing factors. Soil Biol Biochem 78:222-232

Berg B, McClaugherty C (2008) Plant litter, Second ed. Springer-Verlag Berlin Heidelberg

Butenschoen O, Krashevska V, Maraun M, et al (2014) Litter mixture effects on decomposition in tropical montane rainforests vary strongly with time and turn negative at later stages of decay. Soil Biol Biochem 77:121-128

Camenzind T, Hempel S, Homeier J, et al (2014) Nitrogen and phosphorus additions impact arbuscular mycorrhizal abundance and molecular diversity in a tropical montane forest. Glob Chang Biol 20:3646-3659

Camenzind T, Rillig MC (2013) Extraradical arbuscular mycorrhizal fungal hyphae in an organic tropical montane forest soil. Soil Biol Biochem 64:96-102

Das S, Joy VC (2009) Chemical quality impacts of tropical forest tree leaf litters on the growth and fecundity of soil Collembola. Eur J Soil Biol 45:448-454

Dhooria MS (2016) Soil mites. In: Fundamentals of Applied Acarology. Springer, Singapore, pp $197-206$

Fujii S, Takeda H (2017) Succession of soil microarthropod communities during the aboveground and belowground litter decomposition processes. Soil Biol Biochem 110:95-102

Gallardo A, Schlesinger WH (1994) Factors limiting microbial biomass in the mineral soil and forest floor of a warm-temperate forest. Soil Biol Biochem 26:1409-1415. https://doi.org/10.1016/0038-0717(94)90225-9

Hättenschwiler S, Tiunov A V., Scheu S (2005) Biodiversity and litter decomposition in terrestrial 
ecosystems. Annu Rev Ecol Evol Syst 36:191-218

Hodge A, Campbell CD, Fitter AH (2001) An arbuscular mycorrhizal fungus accelerates decomposition and achqires nitrogen directly from organic material. Nature 413:297-299

Homeier J, Hertel D, Camenzind T, et al (2012) Tropical Andean forests are highly susceptible to nutrient inputs-rapid effects of experimental $\mathrm{N}$ and $\mathrm{P}$ addition to an Ecuadorian montane forest. PLoS One 7:

Hoorens B, Coomes D, Aerts R (2010) Neighbour identity hardly affects litter-mixture effects on decomposition rates of New Zealand forest species. Oecologia 162:479-489

Illig J, Norton RA, Scheu S, Maraun M (2010) Density and community structure of soil- and bark-dwelling microarthropods along an altitudinal gradient in a tropical montane rainforest. Exp Appl Acarol 52:49-62

Illig J, Schatz H, Scheu S, Maraun M (2008) Decomposition and colonization by microarthropods of two litter types in a tropical montane rain forest in southern Ecuador. $J$ Trop Ecol 24:157-167

Kaneko N, Salamanca EF (1999) Mixed leaf litter effects on decomposition rates and soil microarthropod communities in an oak-pine stand in Japan. Ecol Res 14:131-138

Kottke I, Beck A, Oberwinkler F, et al (2004) Arbuscular endomycorrhizas are dominant in the organic soil of a neotropical montane cloud forest. J Trop Ecol 20:125-129

Krashevska V, Bonkowski M, Maraun M, et al (2008) Microorganisms as driving factors for the community structure of testate amoebae along an altitudinal transect in tropical mountain rain forests. Soil Biol Biochem 40:2427-2433

Krashevska V, Sandmann D, Marian F, et al (2017) Leaf litter chemistry drives the structure and composition of soil Testate Amoeba communities in a tropical montane rainforest of the Ecuadorian Andes. Microb Ecol 74:681-690

Li Y, Niu S, Yu G (2016) Aggravated phosphorus limitation on biomass production under increasing nitrogen loading: A meta-analysis. Glob Chang Biol 22:934-943

Maraun M, Illig J, Sandmann D, et al (2008) Soil Fauna. In: Beck E, Bendix J, Kottke I, et al. (eds) Gradients in a tropical mountain ecosystem of Ecuador. Springer, Berlin, Heidelberg, pp 181-192 
Maraun M, Martens H, Migge S, et al (2003) Adding to "the enigma of soil animal diversity": Fungal feeders and saprophagous soil invertebrates prefer similar food substrates. Eur J Soil Biol 39:85-95

Marian F, Brown L, Sandmann D, et al (2019) Roots, mycorrhizal fungi and altitude as determinants of litter decomposition and soil animal communities in tropical montane rainforests. Plant Soil 438:1-18

Marian F, Sandmann D, Krashevska V, et al (2017) Leaf and root litter decomposition is discontinued at high altitude tropical montane rainforests contributing to carbon sequestration. Ecol Evol 7:6432-6443

Marian F, Sandmann D, Krashevska V, et al (2018) Altitude and decomposition stage rather than litter origin structure soil microarthropod communities in tropical montane rainforests. Soil Biol Biochem 125:263-274

Nuccio EE, Hodge A, Pett-ridge J, et al (2013) An arbuscular mycorrhizal fungus significantly modifies the soil bacterial community and nitrogen cycling during litter decomposition. Environ Microbiol 15:1870-1881

Pollierer MM, Dyckmans J, Scheu S, Haubert D (2012) Carbon flux through fungi and bacteria into the forest soil animal food web as indicated by compound-specific $13 \mathrm{C}$ fatty acid analysis. Funct Ecol 26:978-990

Pollierer MM, Langel R, Körner C, et al (2007) The underestimated importance of belowground carbon input for forest soil animal food webs. Ecol Lett 10:729-736

Potapov A, Sandmann D, Scheu S (2019) Ecotaxonomy database traits and species

Rillig MC, Camenzind T, Gawlik J, et al (2013) Diversity in Soil Fungi, Protists, and Microarthropods. 81-92

Scheu S (2002) The soil food web: Structure and perspectives. Eur J Soil Biol 38:11-20

Scheu S, Ruess L, Bonkowski M (2005) Interactions and soil micro- and mesofauna. In: Buscot F, Varma A (eds) Microorganisms in soils: roles in genesis and functions. pp 253-275

Schneider K, Migge S, Norton RA, et al (2004) Trophic niche differentiation in soil microarthropods (Oribatida, Acari): Evidence from stable isotope ratios $\left({ }^{15} \mathrm{~N} /{ }^{14} \mathrm{~N}\right)$. Soil Biol Biochem 36:1769-1774 
Siepel H (1994) Life-history tactics of soil microarthropods. Biol Fertil Soils 18:263-278

Talbot JM, Allison SD, Treseder KK (2008) Decomposers in disguise: Mycorrhizal fungi as regulators of soil C dynamics in ecosystems under global change. Funct Ecol 22:955-963

Wilcke W, Yasin S, Abramowski U, et al (2002) Nutrient storage and turnover in organic layers under tropical montane rain forest in Ecuador. Eur J Soil Sci 53:15-27

Zieger SL, Ammerschubert S, Polle A, Scheu S (2017) Root-derived carbon and nitrogen from beech and ash trees differentially fuel soil animal food webs of deciduous forests. PLoS One $12: 1-14$ 


\section{Acknowledgements}

First I would like to thank Stefan Scheu for giving me the opportunity to be his Ph.D. student and for all the support that I always received from him. I have got nothing but words of gratitude. I could not have had a better thesis supervisor!

Thanks also to Christoph Bleidorn for being always open to help. Thanks also to Mark Maraun for being super enthusiastic and positive with all the results. Was always nice to talk with you both.

I especially would like to thank Franca for all her help and patience. I really enjoyed our discussions about results! I will never forget that I started in the AG-Scheu as her Hiwi, we went to Ecuador and she trained me for the fieldwork. Thanks for all Franca!

I would also like to thank Tamara for her helpful comments and for spending her time reading and correcting the redaction and English of my papers and the thesis. Was really nice to count on you! Thanks a lot Tamara.

Thanks also to Doro, Anton, and Melanie for all their helpful comments, to Logos for his help with statistics and R, to Jochen and Yako for being my friendly office colleagues, to Winda for been always super positive and share her good vibes, and to my favorite TA: Guido, I am pretty sure he will forever remember my 20 samples of Fatty acids in a row. I had a really nice time in the lab and also talking with him

And finally, thanks to all the AG-Scheu members...

I enjoy all the trips, parties and barbecues...

Was very nice to be part of this working group and have colleagues like you all!

Before to switch the language, I would like to thank Marcel for his unconditional support, for helped me always with Teo and the endless German translations. Is nice to know that you have been part of my life during some years of this adventure. Thank you Klattcito! And of course, thanks to all the Klatt members for being like a second family for me. 
Cambiando el idioma, primero quiero dar las gracias a mis padres y a mi hermano por haberme apoyado con mi idea loca de venir a Alemania sin algo fijo, sin ellos no habría llegado hasta acá. Muchas gracias, los amo con el alma. Al final el tiempo que he pasado lejos de ustedes ha valido la pena.

También le quiero dar las gracias a mis dos grandes amigas Odette y Magda. Son lo mejor que me ha dejado mi estancia en Göttingen. Han sido mi apoyo en muchas situaciones. Siempre recordaré todas las cosas que hemos vivido, buenas y malas. Hemos pasado por muchas chicas ¡Las quiero chicas!

Me gustaría también las gracias a todos los amigos que he tenido durante esta etapa en Göttingen, en especial a Pablinchis, Fabito, Juanito, Naty y a Dani Ramos. Gracias por las fiestas, los almuerzos, las charlas de la vida y de tonterías... ¡Muchas Gracias chicos! hicieron mi vida mas agradable y ha sido genial haberles conocido. Espero la vida nos cruce en algún momento de nuevo.

Quiero darle un agradecimiento especial a Arturo, porque sin él no habría considerado venir a Göttingen. Gracias por haberme ayudado a empezar en Alemania y por haberme apoyado durante los primeros años del doctorado. Indiscutiblemente ha sido mi locura mas grande, pero me trajo muy buenos resultados ¡Gracias Vera!

Aprovecho también para dale las gracias al Encantor, por su compañía y su apoyo durante las últimas etapas de este largo proceso. $\mathrm{Y}$ en general gracias a todas las personas que en algún momento hicieron parte de una charla, una fiesta, una cena, hasta de un chisme, me he divertido y lo agradezco.

Por último y no menos importante, quiero darle las gracias a Teo, él ha sido mi compañía y mi apoyo incondicional, el que me aguanta en las buenas y malas, es ese ángel que me motiva cuando me siento agotada. ¡Te amo Teito, gracias por se mi perrito y estar ahí siempre!

Gracias Dios por esta oportunidad es algo que siempre llevaré en mi corazón (:) 


\section{List of publications}

\section{Published in peer-reviewed journals}

- Sánchez-Galindo LM, Camenzind T, Maraun M, Scheu S (2019) Impacts of core rotation, defaunation and nitrogen addition on arbuscular mycorrhizal fungi, microorganisms and microarthropods in a tropical montane rainforest. Trop Ecol $60: 350-361$

- Sánchez-Galindo LM, Sandmann D, Marian F, Krashevska V, Maraun M, Scheu S (2021) Leaf litter identity rather than litter diversity shapes microbial functions and microarthropod abundance in tropical montane rainforests. Ecology and Evolution. DOI: $10.1002 /$ ece 3.7208

\section{Submitted}

- Sánchez-Galindo LM, Sandmann D, Marian F, Lauermann T, Maraun M, Scheu S (2020) Differences in leaf and root litter decomposition are mediated by soil microorganisms not decomposer microarthropods in tropical montane rainforests. Biotropica. 


\section{Thesis declarations}

\section{Declaration of the author's own contribution to manuscripts with multiple authors}

The study presented in Chapter 4 was set up by me with additional help of Tessa Camenzind and Ecuadorian helpers (see acknowledges). The resulting manuscript is published in Tropical Ecology (60:350-361). The study presented in chapter 2 was set up and collected by Dorothee Sandmann and Franca Marian. The resulting manuscript is currently submitted in Ecology and Evolution. The study presented in chapter 3 was set up and collected by Dorothee Sandmann and Franca Marian. Samples of the different sampling dates were sorted with the help of Tobias Lauermann and is submitted in Biotropica.

I am the first author of all chapters; I have developed the main ideas, analyzed the data, written the manuscripts and created tables, figures and supplementary materials. The study design of each study was developed in the framework of the DFG Research Unit "Biodiversity and Sustainable Management of a Megadiverse Mountain Ecosystem in South Ecuador" with the financial support of Deutsche Forschungsgemeinschaft (DFG; FOR816). All persons contributing to the manuscripts have been named. All co-authors contributed to finalizing the manuscripts.

The cover-photographs were all taken by me, Franca Marian and Dorothee Sandmann (see acknowledgements). 


\section{Plagiarism declaration}

I declare that I have written this doctoral thesis independently. All persons contributing to the manuscripts have been named so. All sentences or passages quoted from other people's work have been specifically acknowledged by clear cross-referencing.

I also declare that I have not submitted this thesis in any form for another degree at any university or institution.

Laura Margarita Sánchez Galindo

Göttingen, 22 December 2020 